\title{
ROOTS OF REFORM: \\ CONTEXTUAL INTERPRETATION OF CHURCH FITTINGS IN NORFOLK DURING THE ENGLISH REFORMATION
}

\author{
Thesis submitted for the degree of \\ Doctor of Philosophy \\ at the University of Leicester
}

by

Jason Robert Ladick MA, MS

School of Archaeology and Ancient History

University of Leicester

April 2017 


\section{Abstract}

Title: Roots of reform: a contextual interpretation of church fitting in Norfolk during the English Reformation

Author: Jason Robert Ladick

This thesis aims to provide a thorough examination of the impact of the English Reformation through a detailed analysis of medieval and early modern church fittings surviving at parish churches located throughout the county of Norfolk in England. By utilizing an archaeological approach along with the written record, a deeper and more nuanced understanding of public worship reveals the theological imperatives of the reformers and conformers.

This study compiled data from both rural and urban parish churches which provides a regional approach to engaging the issues of visuality, space and identity. Church fittings were selected based on their liturgical function and propensity to feature decorative iconography. This includes: baptismal fonts, screens, wall paintings, and sculptures.

Through an extensive analysis of church fittings, this research is the first to suggest that the Bible-centric component to Protestant theology provided the framework which contributed to the success of the Reformation. The religious identity of England was transformed as visual continuity enabled an entire generation to continue their religious experience in a traditional context in spite of the moderate alteration to liturgy and comprehensive transformation of doctrine. This criterion eased the transition, as liturgical continuity and selective iconoclasm forged a new physical religious environment that retained enough elements to satiate traditionalist. The reformers were appeased into conformity, as Protestant doctrine redefined the purpose of the surviving rituals and iconography, with the latter emerging as a visual extension of the campaign to promote the primacy of Scripture. Furthermore, an assessment of post-Reformation innovations reveals the use of vernacular Biblical text as a preferred mode of decoration, with an increase in the use of secular heraldry and commemoration directly on church fittings. 


\section{Acknowledgement}

I would like to thanks those who contributed to my personal growth as a scholar: Dr. Seth Armus of St. Joseph's College, who trained me as a historian; David Guillfoyle, who helped me develop as a field archeologist; and to Dr. Jane Clay, for her encouragement, friendship and editing talents.

The fieldwork for this study would not have been possible without the aid of the librarians at the Norfolk Heritage Centre at the Norfolk and Norwich Millennium Library, and the staff and caretakers at the various parishes churches surveyed.

I would also like to express my immense gratitude to my thesis supervisor, Dr. Deirdre O'Sullivan for her guidance and support throughout this entire process. In addition, I would like to thank Dr. Chris King, who encouraged me to explore the parish churches in Norfolk and inspired me to continue the research I began under his tutelage.

This work would have been inconceivable without the support and patience of my family, friends, and professional colleagues. Finally, I want to thank my wife, Christina, for her love and dedication throughout this entire process. Our dichotomy of faith helped keep this research alive and vibrant, as the divisions of the sixteenth and seventeenth century are reconciled within the life we are building together.

All photographs have been taken and edited by the author unless otherwise stated. 


\section{Table of Contents}

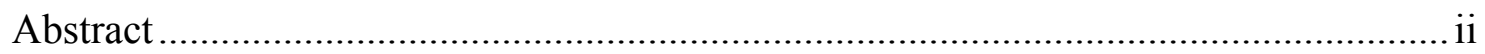

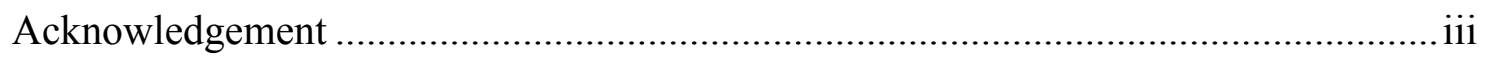

Table of Contents ............................................................................................ iv

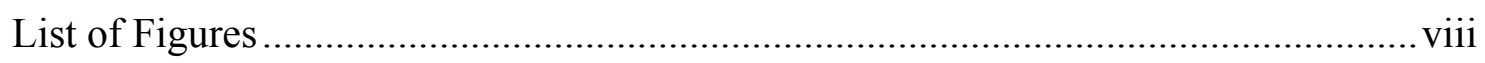

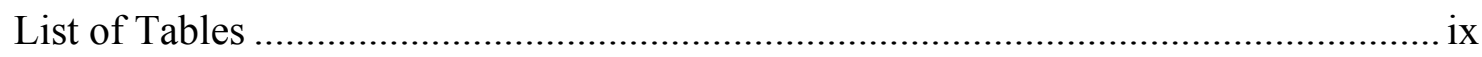

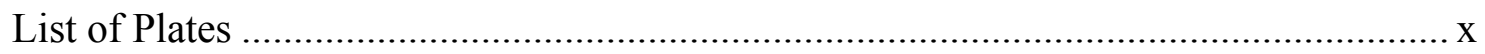

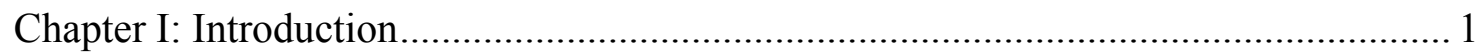

Chapter II: Methodology \& Sources ................................................................... 4

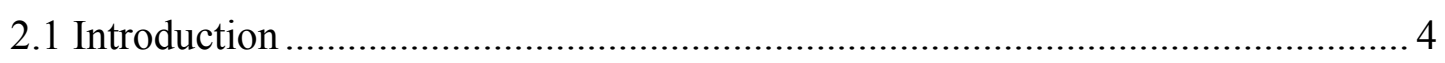

2.2 Research Question.................................................................................... 4

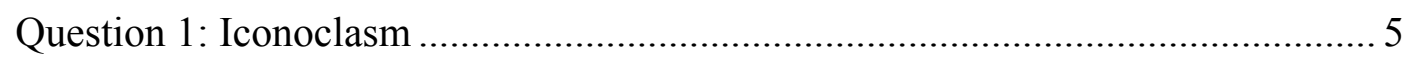

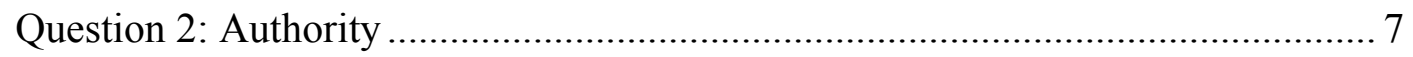

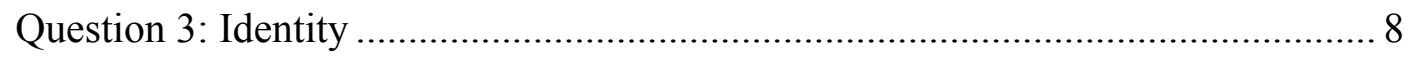

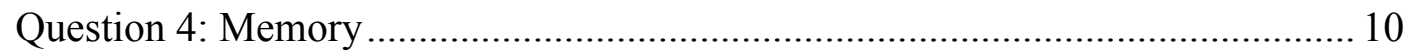

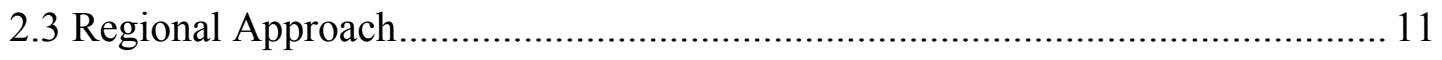

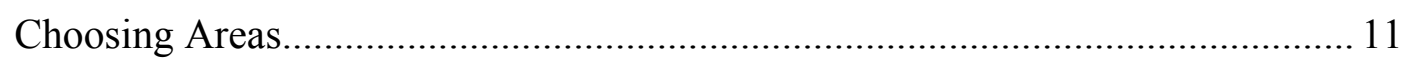

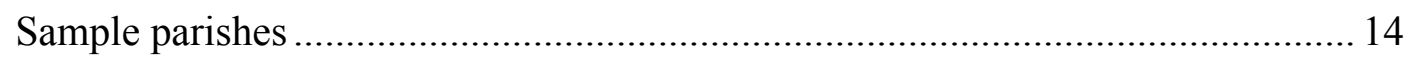

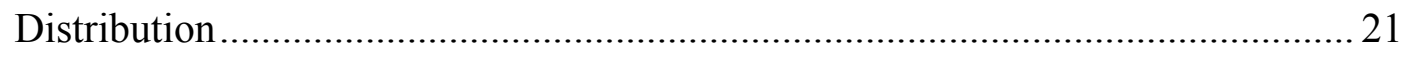

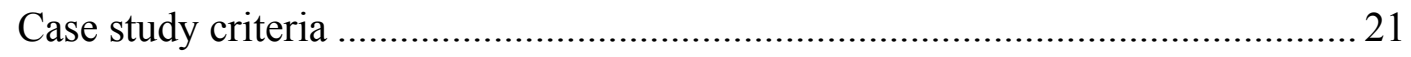

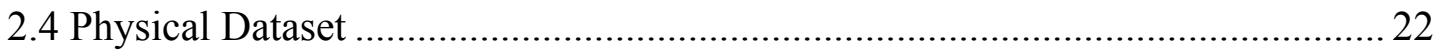

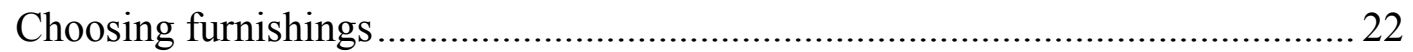

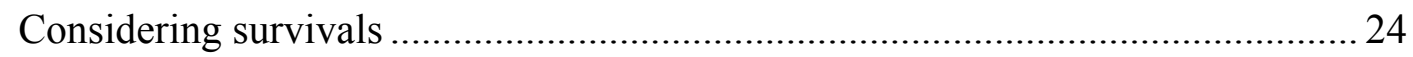

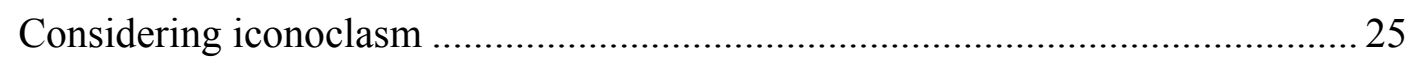

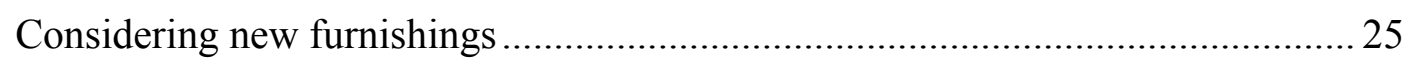

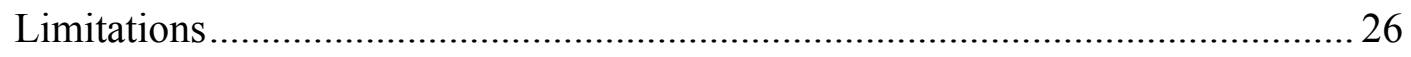

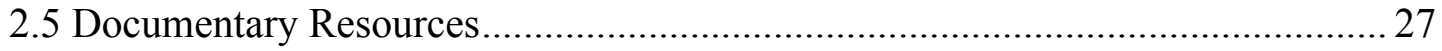

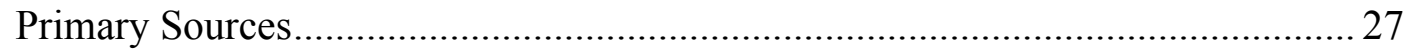

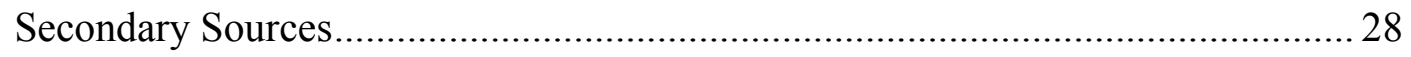

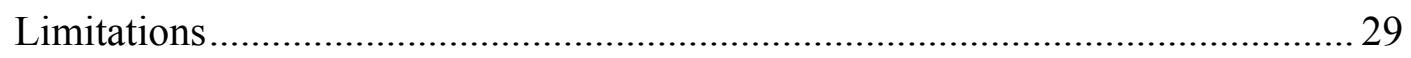

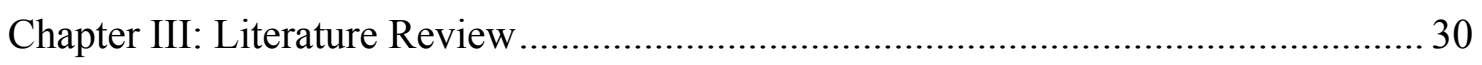

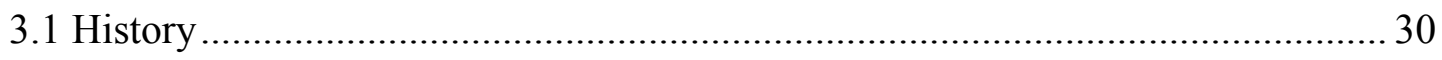




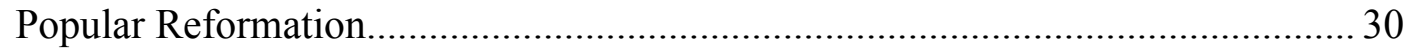

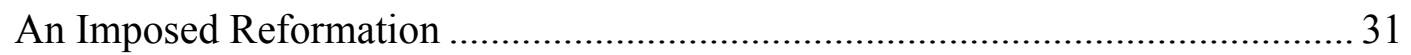

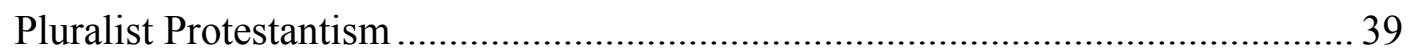

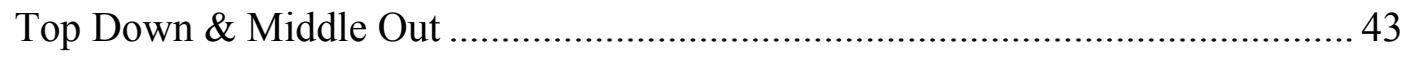

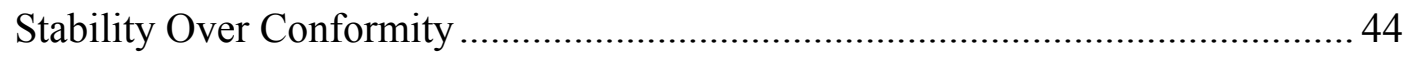

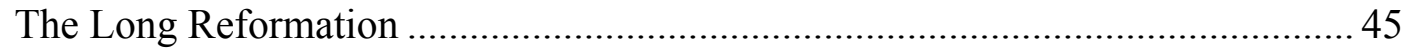

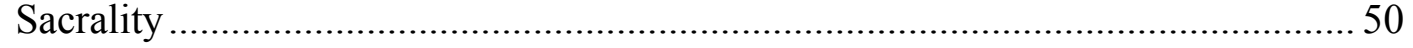

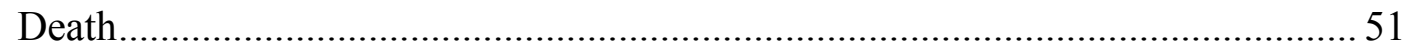

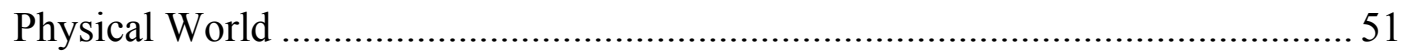

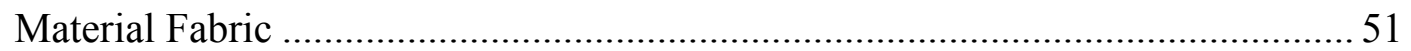

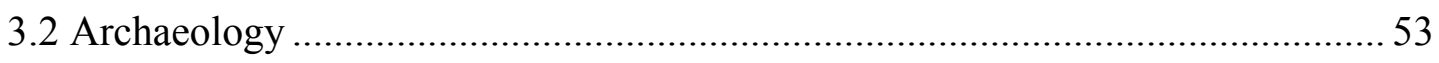

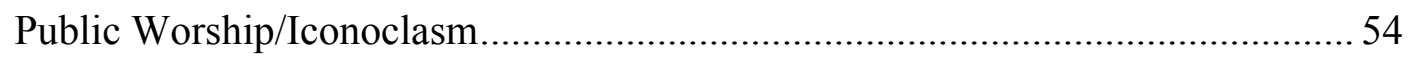

Private Devotion/Material Culture ………......................................................... 54

Dissolution/Secular Power/Corporate Charities .................................................... 55

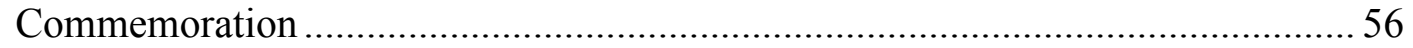

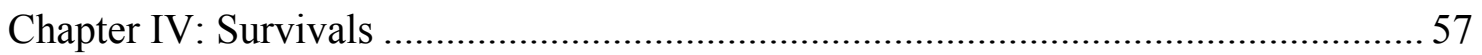

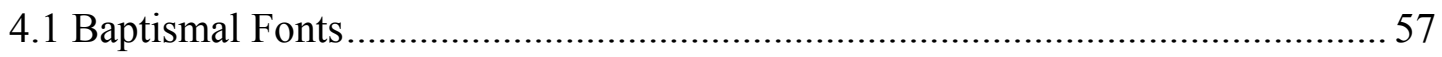

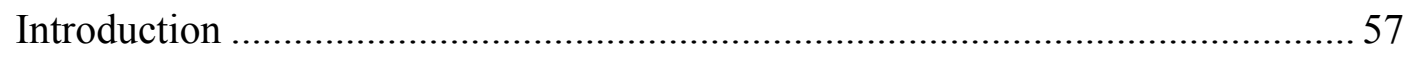

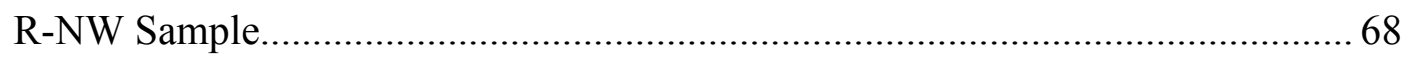

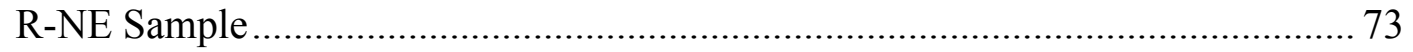

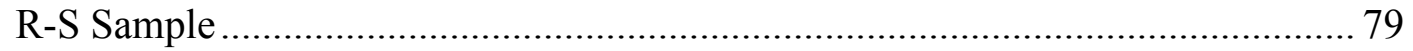

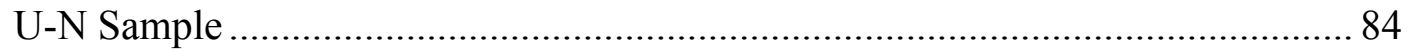

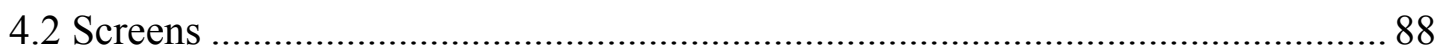

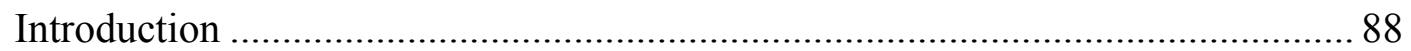

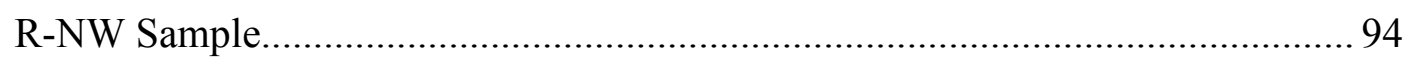

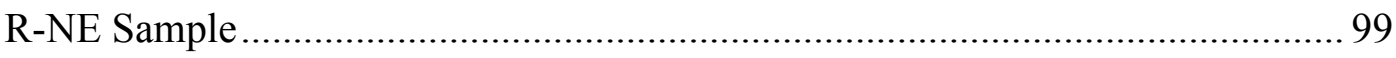

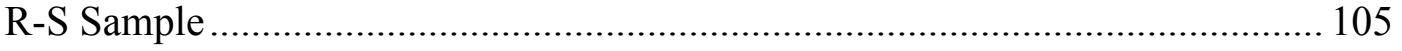

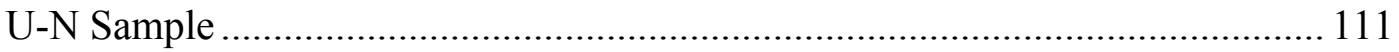

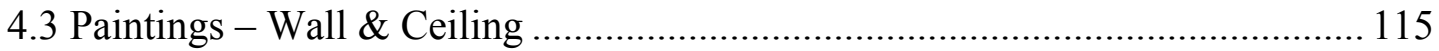

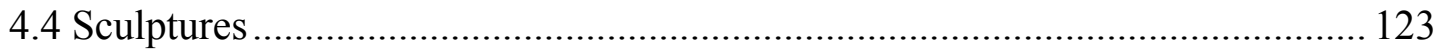

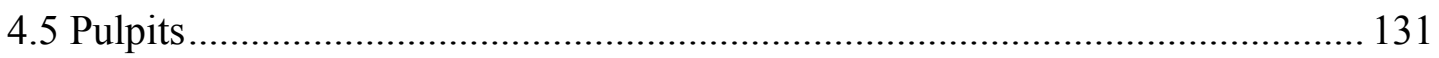

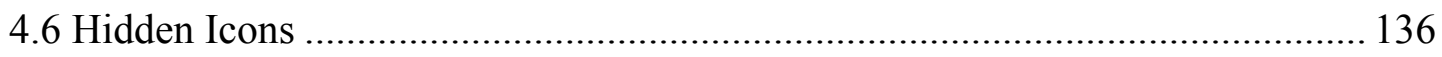

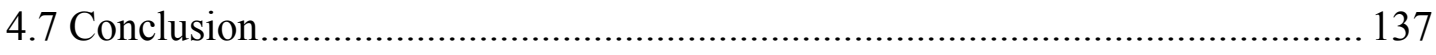




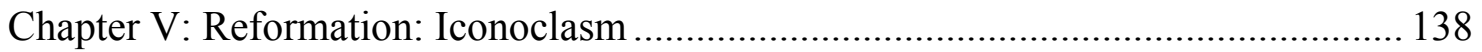

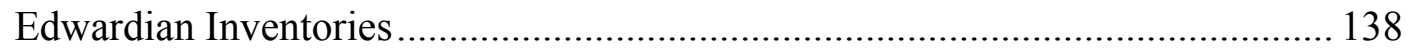

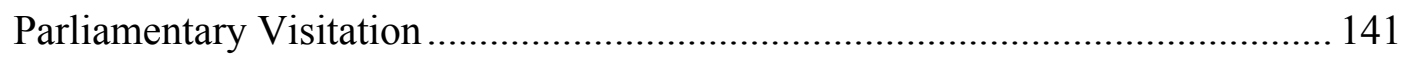

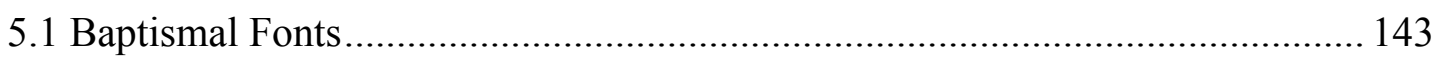

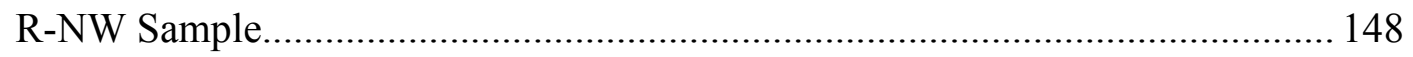

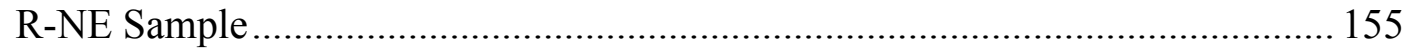

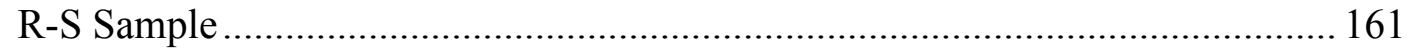

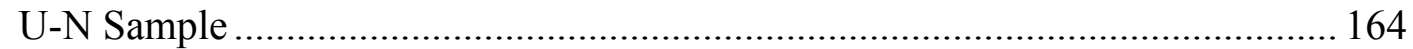

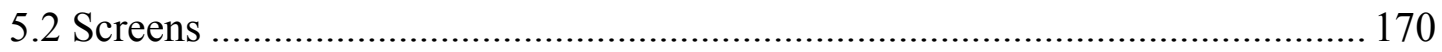

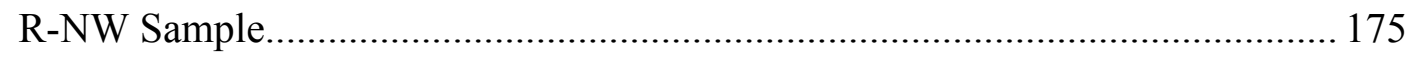

R-NE Sample ........................................................................................ 182

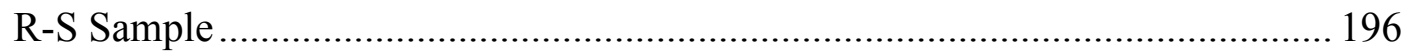

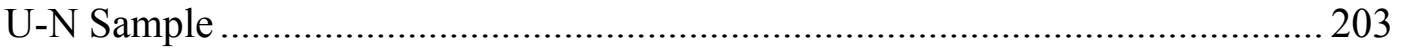

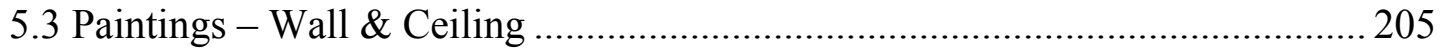

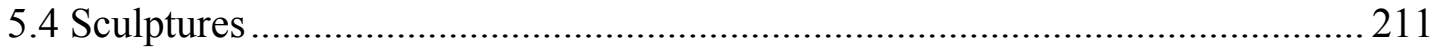

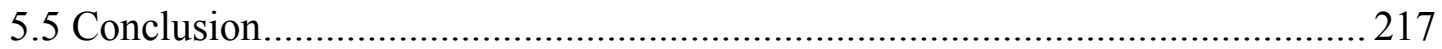

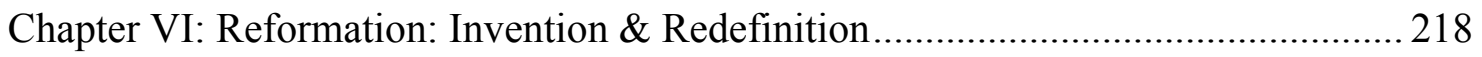

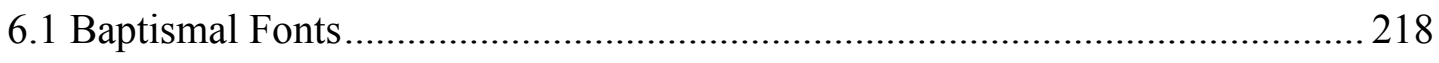

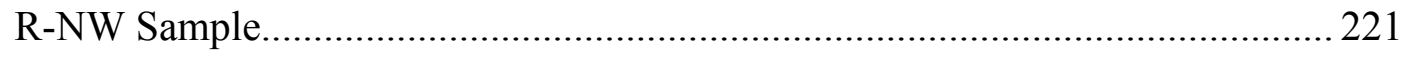

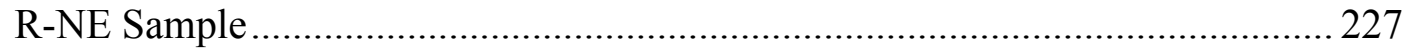

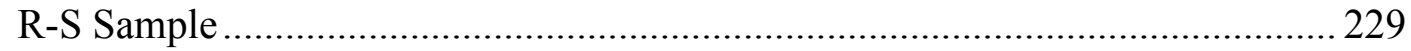

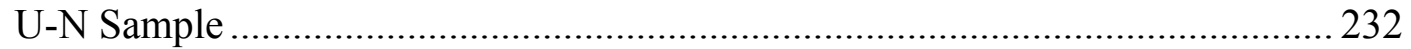

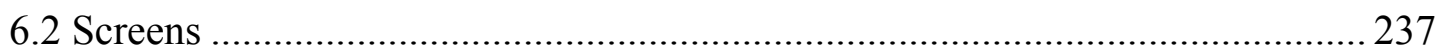

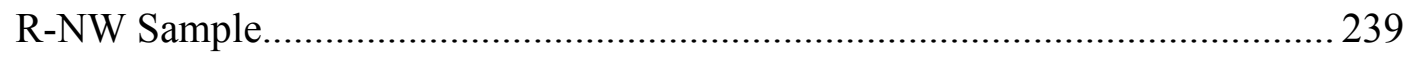

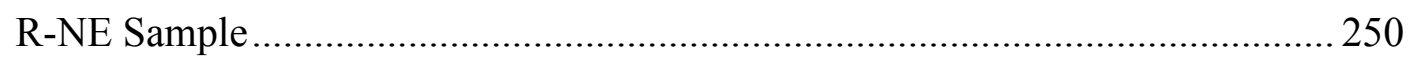

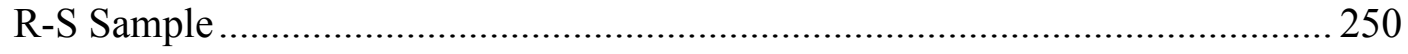

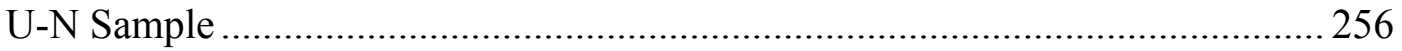

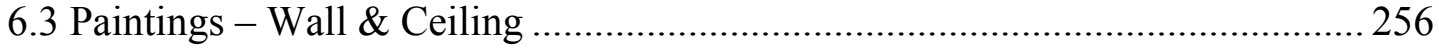

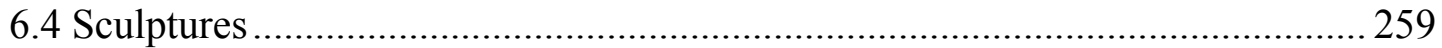

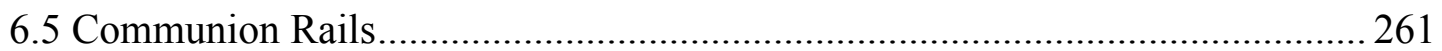

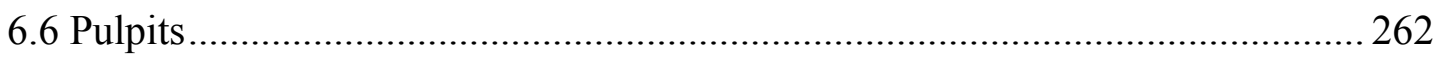

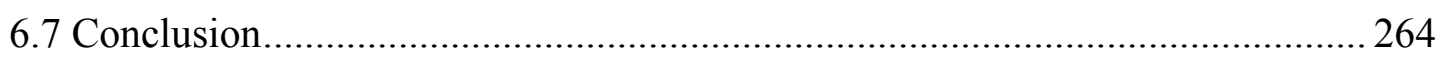

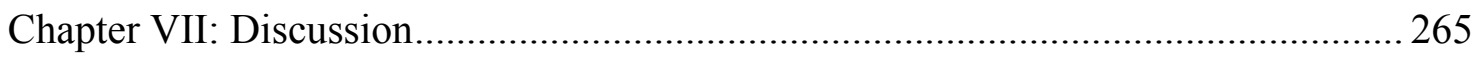




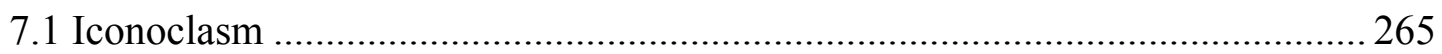

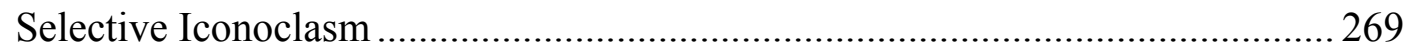

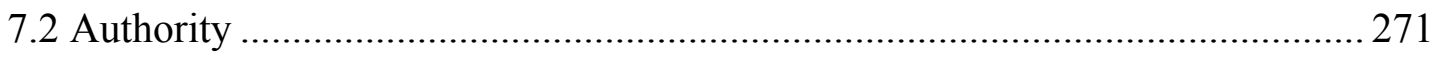

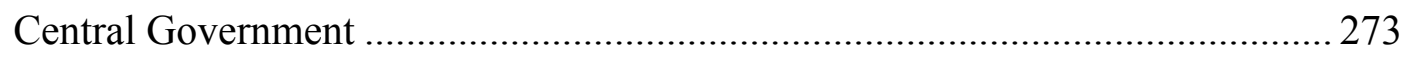

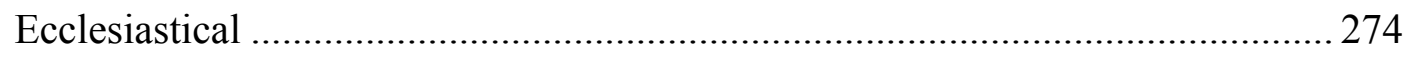

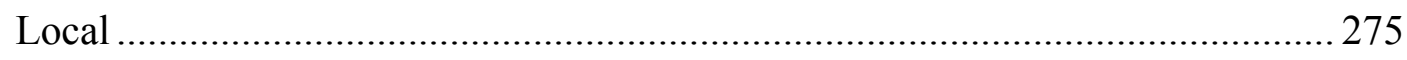

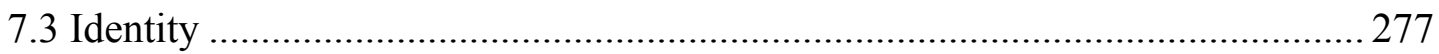

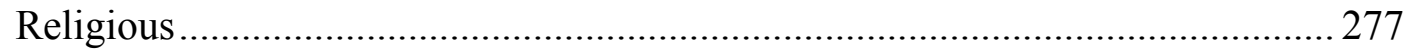

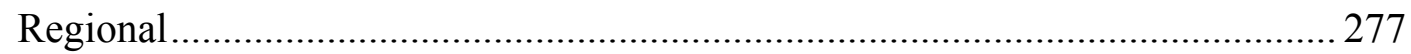

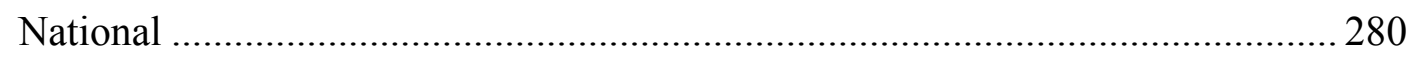

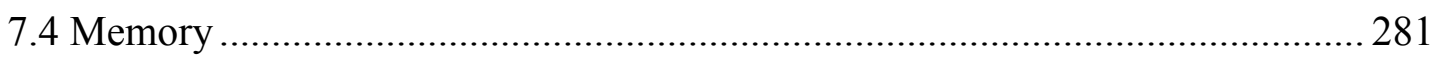

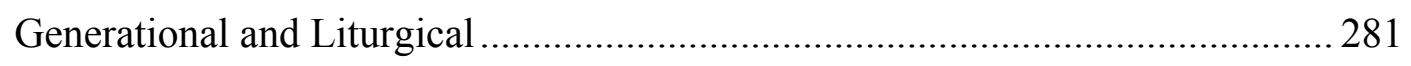

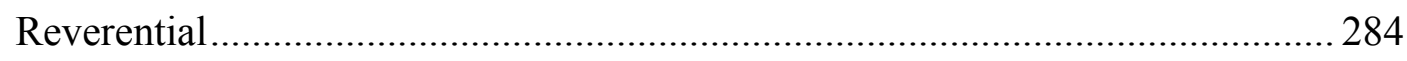

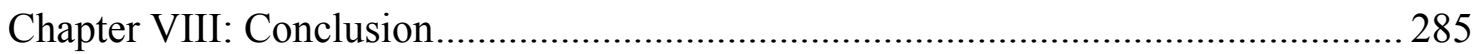

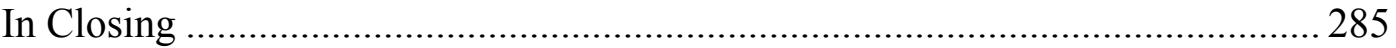

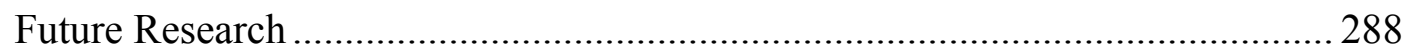

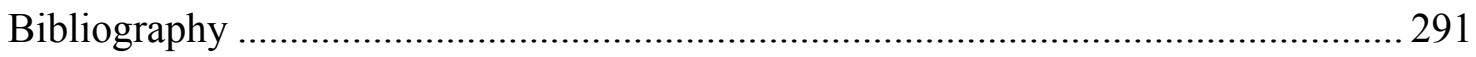




\section{List of Figures}

Figure 1: Norfolk Sample Groups \& Parish Totals (as of 1552) ................................. 16

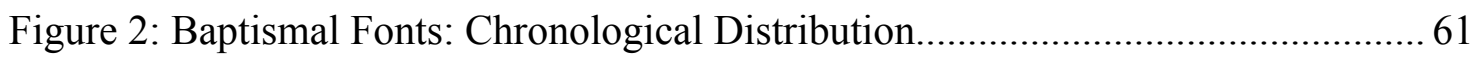

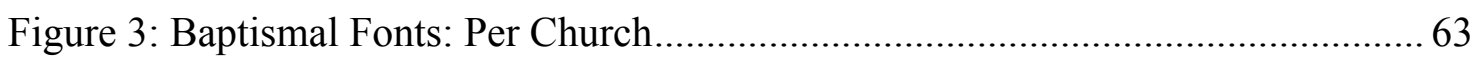

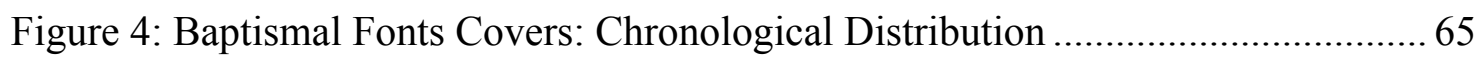

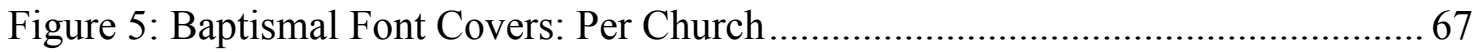

Figure 6: Screens Chronological Distribution .............................................................. 91

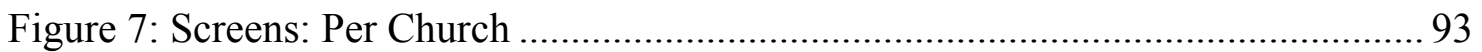

Figure 8: Paintings - Wall/Ceiling Chronological Distribution ................................ 117

Figure 9: Paintings - Wall/Ceiling: Per Church ....................................................... 119

Figure 10: Pulpits: Chronological Distribution........................................................ 133

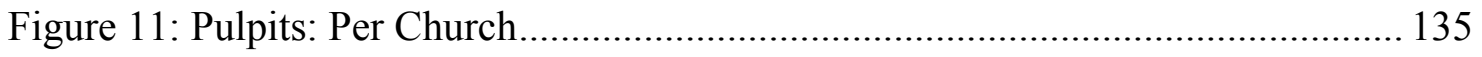

Figure 12: Baptismal Font: Rate of Iconoclasm ........................................................ 146

Figure 13: Baptismal Fonts: Map Distribution ........................................................ 147

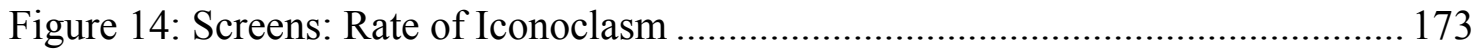

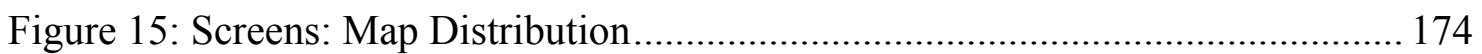

Figure 16: Roof Bosses at Norwich Cathedral: Rate of Iconoclasm ......................... 214

Figure 17: Communion Rails: Per Church................................................................ 262 


\section{List of Tables}

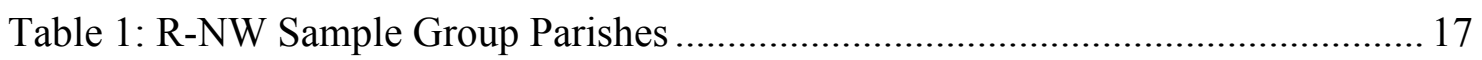

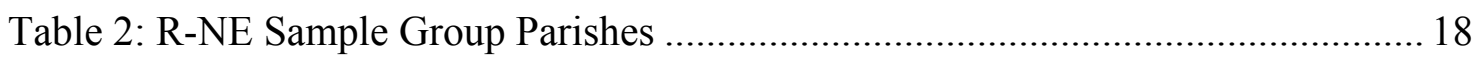

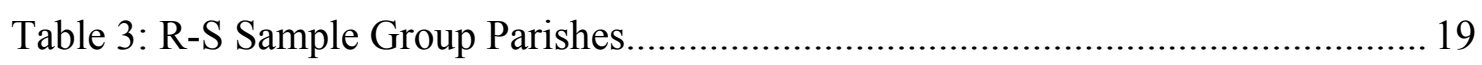

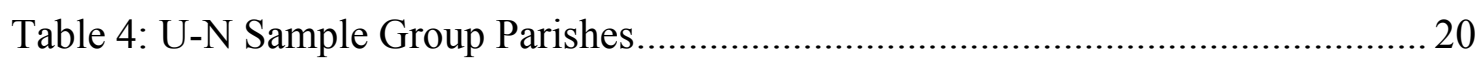

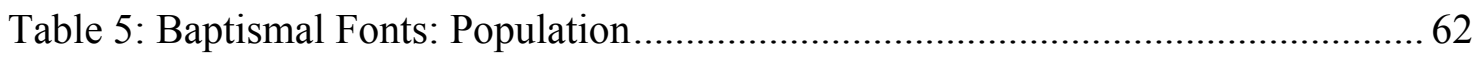

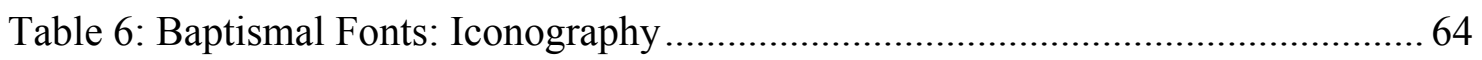

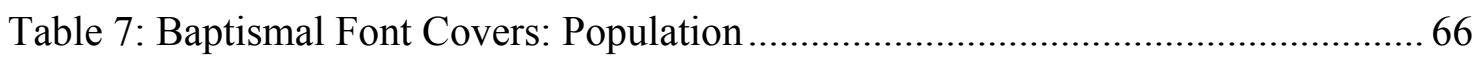

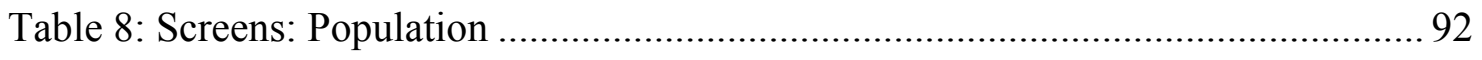

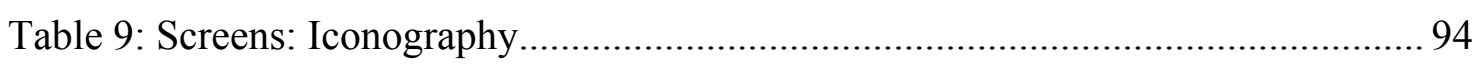

Table 10: Paintings - Wall/Ceiling: Population ...................................................... 118

Table 11: Paintings - Wall/Ceiling: Iconography .................................................. 119

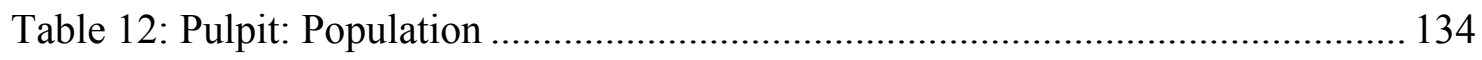

Table 13: Edwardian Inventory in Rural Samples ................................................... 140

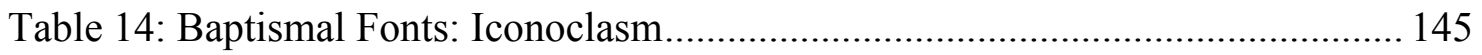

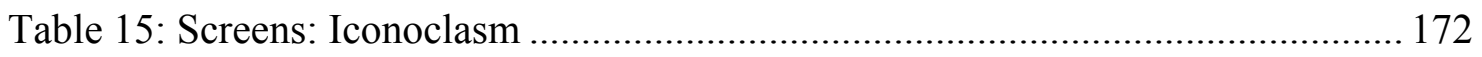

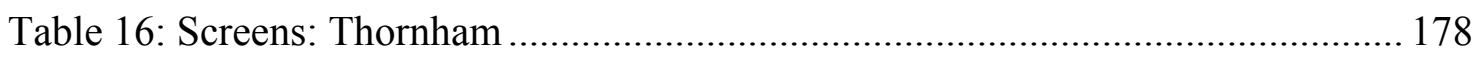

Table 17: Roof Bosses at Norwich Cathedral: Iconoclasm ...................................... 214

Table 18: Baptismal Fonts: Produced 1534-1660 .................................................... 220

Table 19: Baptismal Font Covers: Produced 1534-1660 …......................................... 220

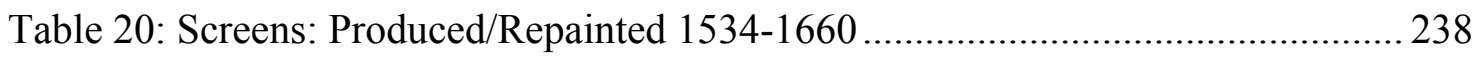

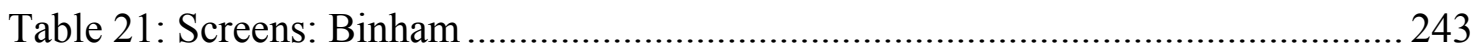




\section{List of Plates}

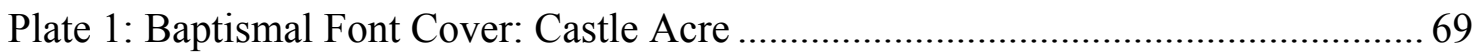

Plate 2: Baptismal Font: Burnham Deepdale............................................................... 72

Plate 3: Baptismal Font: Sloley............................................................................. 75

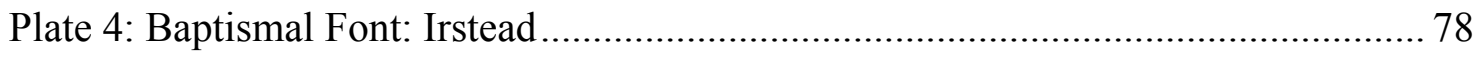

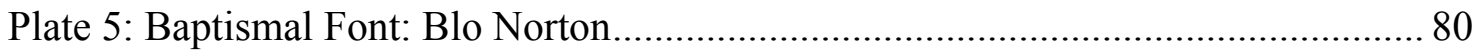

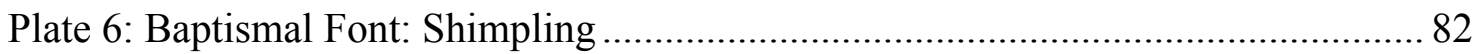

Plate 7: Baptismal Font: Norwich St John de Sepulchre ............................................ 85

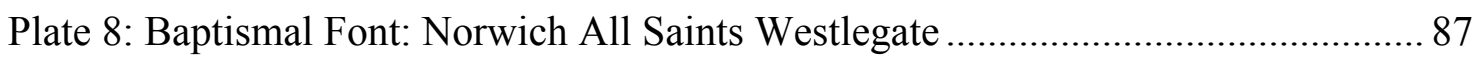

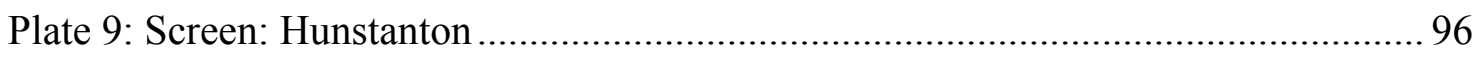

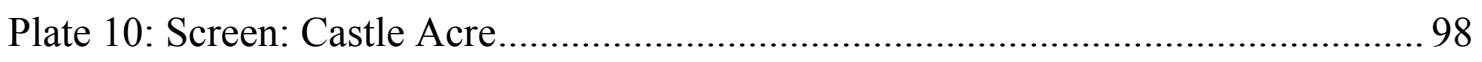

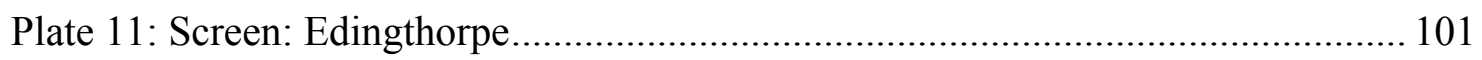

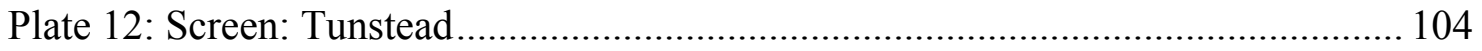

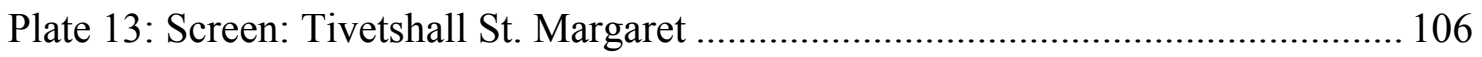

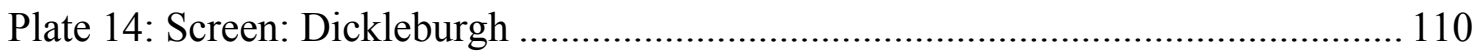

Plate 15: Screen: Norwich St James at St. Mary Magdalene..................................... 112

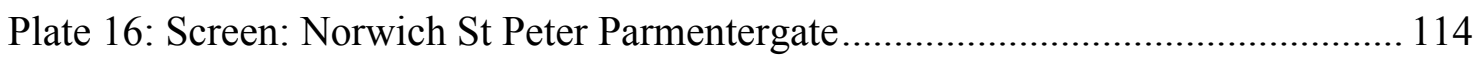

Plate 17: Wall Painting: North Creake- Last Judgement ......................................... 120

Plate 18: Wall Painting: Heydon and Paston - Three Dead Kings .............................. 122

Plate 19: Sculptures: Norwich Cathedral Nave .......................................................... 128

Plate 20: Sculptures: Norwich Cathedral Cloister. Part One ...................................... 129

Plate 21: Sculptures: Norwich Cathedral Cloister. Part Two ..................................... 130

Plate 22: Lectern: Norwich Cathedral.................................................................... 136

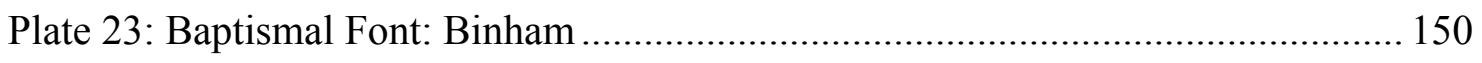

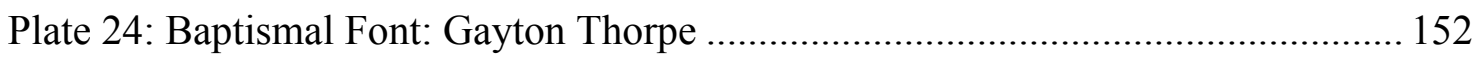

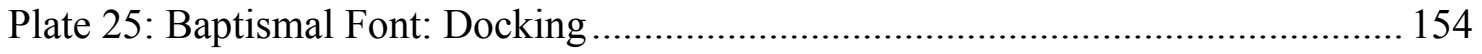

Plate 26: Baptismal Font: Burgh-next-Aylsham.................................................... 157

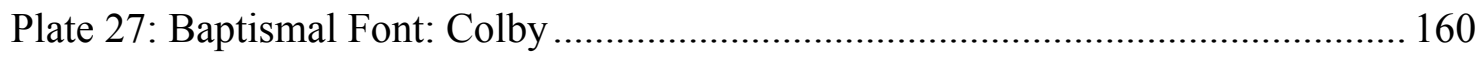

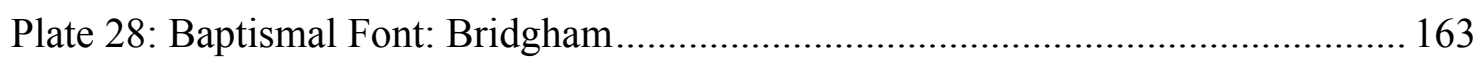

Plate 29: Baptismal Font: St Mary in the Marsh. Part One ........................................ 166

Plate 30: Baptismal Font: St Mary in the Marsh. Part Two....................................... 167

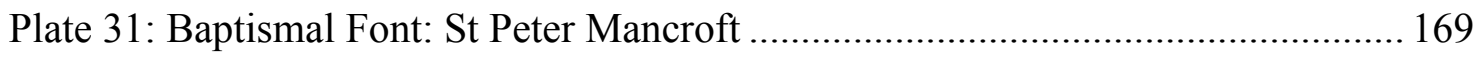


Plate 32: Screen: Thornham. South Side 179

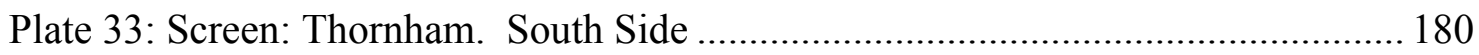

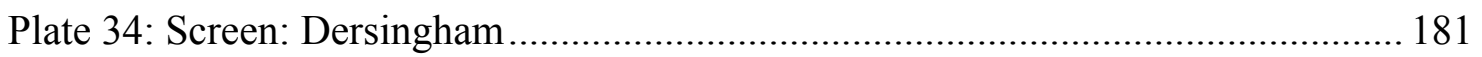

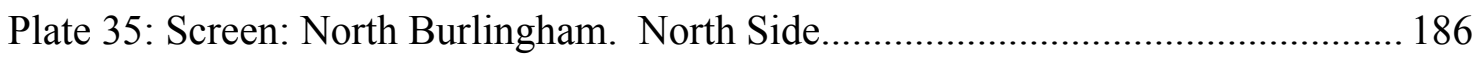

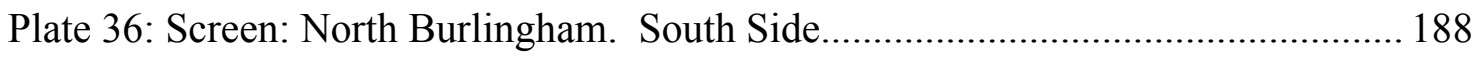

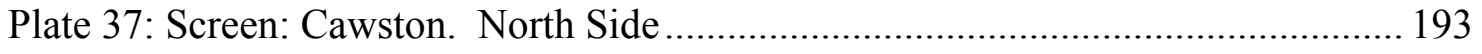

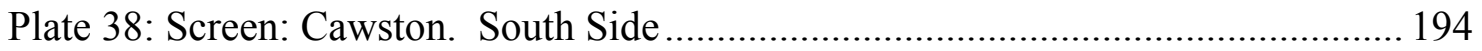

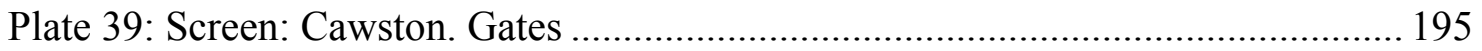

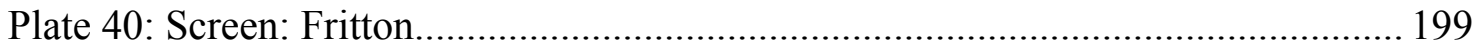

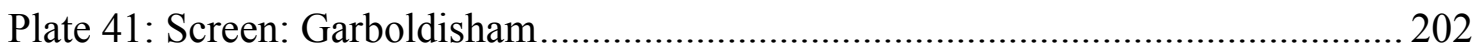

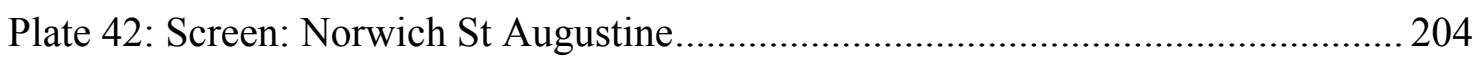

Plate 43: Wall Painting: Norwich Cathedral. Ante-Reliquary Chapel ...................... 207

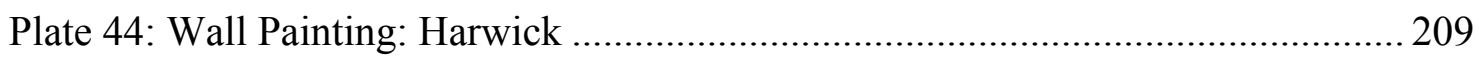

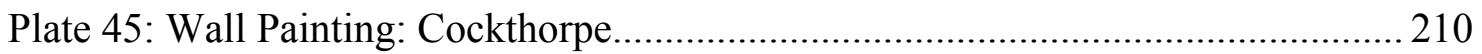

Plate 46: Sculptures: Norwich Cathedral Cloister. Part One - Damaged ..................... 215

Plate 47: Sculptures: Norwich Cathedral Cloister. Part Two - Damaged..................... 216

Plate 48: Baptismal Font: Cockthorpe .................................................................... 222

Plate 49: Baptismal Font: King's Lynn St Nicholas .................................................. 224

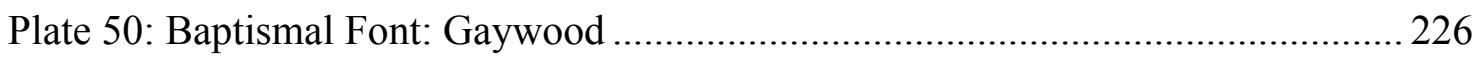

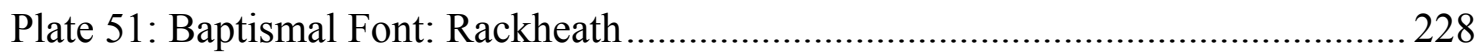

Plate 52: Baptismal Font: New Buckenham ............................................................... 230

Plate 53: Baptismal Font: Ashwellthorpe ….............................................................. 231

Plate 54: Baptismal Font: Norwich St Gregory Pottergate......................................... 232

Plate 55: Baptismal Font Cover: Norwich St Stephen.............................................. 235

Plate 56: Baptismal Font Cover: Norwich St Andrew ............................................ 236

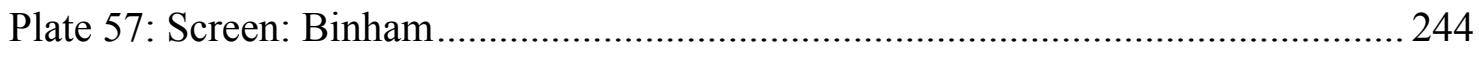

Plate 58: Screen: King's Lynn St Margaret ….......................................................... 249

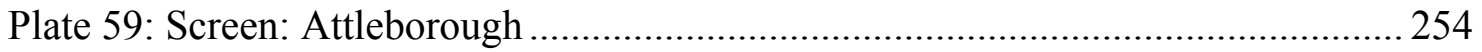

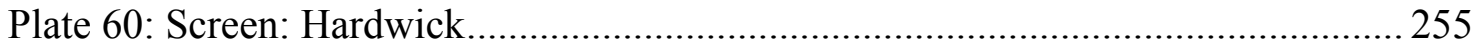

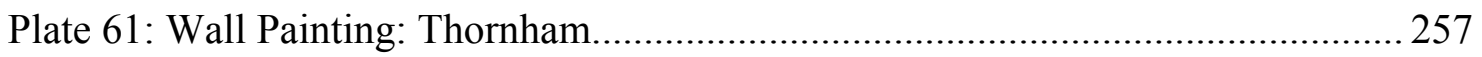

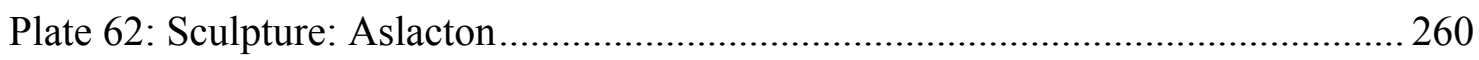




\section{Chapter I: Introduction}

The English Reformation can be defined as a cataclysmic series of occurrences that shattered the medieval landscape and established the primordial framework for a modern western society. The religious and political upheaval, instigated by the House of Tudor, brought about socioeconomic innovation while redefining cultural expectations in regards to both identity and authority. While historians have fiercely debated if these actions were an unwelcome imposition, or reflected the emerging will of the realm, the reality cannot be disputed that England underwent a decisive break with papal authority and the Roman Catholic Church during the sixteenth century. What can be contested is to what extent the Church of England was successful in establishing a genuinely Protestant nation in the model of continental Calvinism, Lutheranism and Zwinglianism.

The consequences of this transition during the sixteenth century would unfold in the following century against the backdrop of a new royal dynasty, as the Stuarts met the challenges of sovereignty, finances, religion, foreign policy and local control. Within this chronological context, this study will provide new insight into the causes of the Reformation, while gauging the effectiveness of its success by the Restoration of the monarchy in 1660 .

While the English Reformation has often been the domain of historians, due to the expansive collection of documentary sources available during the period, archaeology can contribute to this discussion by assessing the variances in religious inclinations held by both the ruling class and commonality. Religious structures, including parish and cathedral churches, retain a vast wealth of material that existed or was created, throughout the period in review. Church fittings, defined as any furnishings or fixtures, all possess a religious purpose through either their liturgical function or chosen decorative motifs. An evaluation of the material record should not succumb to the temptation to draw conclusions based solely on the evidence for destruction, as the extreme acts of iconoclasm is one of the hallmarks of Reformation archaeology. Instead, a thorough appraisal of medieval survivals and early modern innovations 
provides an even richer context by revealing the real attitudes towards Reformation in practice, rather than principle. Furthermore, it will offer a glimpse into local dynamics that may have influenced parishioners to either take action themselves or allow external forces to disrupt, destroy or seize the physical trappings and valuables of their churches.

Archaeology is also capable of supplementing the historical record in regards to the evolving sense of sacrality. The widespread 'erosion of the sacred' compromised the medieval ideals of spatial holiness within consecrated buildings. Also, the secularization of religion's monopoly on charity, education, and healthcare played a significant role in engineering the archetype of the modern state.

This study utilizes both an archaeological approach and the written record to simultaneously challenge and augment earlier historiographies of the English Reformation through an extensive research of fittings surviving in parish churches across the county of Norfolk in the area of East Anglia, located in the East of England. The material record considered includes both medieval furnishing and fixtures and early modern innovations up 1660 . This research is both timely and felicitous as the current state of affairs sees a country experiencing the consequences of withdrawing from a sociopolitical institution that transcends European borders in favor isolationist nationalism.

This work incorporates five research questions, which will be outlined and expanded in the following chapter in greater detail, designed to answer the central inquiries of how the Reformation happened and to what extent it succeeded. The endurance and creation of church fittings during this period were intimately tied to the prevailing theology of the Reformation, with both iconographic ornamentation and liturgical function being the two most crucial factors. Concurrently, the role of sacrality within the consecrated domain of a church will be examined through the placement, or removal, of such fittings.

This thesis is arranged as follows: 
Chapter II outlines the research questions and methodological approaches used to interpret church fittings and assess their role in identity and authority in urban and rural Norfolk during, and beyond, the English Reformation, with the 1534 Act of Supremacy and 1660 Restoration serving as chronological boundaries for early modern refittings.

Chapter III will provide both a literature review designed to offer proper context for this study. This overview of the previous historical and archaeological work and arguments on the English Reformation will provide the requisite background needed to place this study's contributions within the broader historiography.

Chapter IV presents the quantitative data and qualitative case studies for medieval church fittings produced before 1534 across the four sample groups, as defined in Chapter II.

Chapter $\mathbf{V}$ presents the quantitative data and qualitative case studies for church fittings produced up to 1534 that retain traces of iconoclasm across the four sample groups, as defined in Chapter II.

Chapter VI presents the quantitative data and qualitative case studies for church fittings produced between 1534 and 1660 across the four sample groups, as defined in Chapter II.

Chapter VII discusses and interprets the results of the preceding three chapters while addressing the central inquiries regarding the English Reformation. These investigations include: what occurred, why it happened, when it took place, who was involved and how such a monumental shift in society could transpire in such a relatively short period.

Chapter VIII summarizes the conclusions of the research, readdressing the five research questions asked in Chapter II. This Chapter will also introduce recommendations for additional research which could expand this study. 


\section{Chapter II: Methodology \& Sources}

\subsection{Introduction}

This section outlines the research questions, and methodological approaches used to interpret church fittings and assess their role in identity and authority in urban and rural Norfolk during, and beyond, the English Reformation. An analytical method, which was used in the examination of the surviving material record, is outlined and defined in this section; also, the documentary evidence related to the parishes will be explored and discussed. The tactile nature of medieval Catholicism, combined with surviving texts, renders the period as a moment in time best addressed through the proper application of historical archaeology. A balanced physical and documentary approach is paramount and will be applied in tackling such a complex social and cultural phenomenon as the religious upheaval of the Reformation.

\subsection{Research Question}

Throughout this section, the significance of a transforming relationship between the people and the physical manifestations of their beliefs, which in turn contributed to a new identity based on literacy and rationality, will be stressed. This research utilizes four themes that the archaeological and documentary analysis aims to address, in order to understand more fully the role of church fittings during the English Reformation in the parish churches of Norfolk.

The primary objective of this study is to engage with the historiography of the period without necessarily providing a holistic explanation for how and why the Reformation occurred. Instead, the central question is how and why church fittings found across the sample groups survived in the forms they do. This inquiry will engage with the prevailing archaeological themes used in the assessment of the material culture found within parish churches during the Reformation: iconoclasm, or the ritual destruction of objects; the transformation of traditional societal power and institutional authority; local identity, both religious and societal; and memory, both personal and generational. 


\section{Question 1: Iconoclasm}

This study will examine the decorative motifs uncovered on surviving fittings or referenced in documentary sources. This inquiry seeks to identify a trend among iconographic depictions to identity those that were acceptable and spared, those that were deemed offensive and removed and those selected for new fittings. The primary research questions

Iconoclasm, or the destruction of ritual objects, is one of the richest themes explored by historians and archaeologists in regards to the Reformation. Two the most compelling approaches taken are iconoclasm as a form of religious expression and iconoclasm as the death of an object. This work will extend these themes to further uncover the 'intelligence' demonstrated in the methods and approaches of destruction while attempting to surmise the theological imperatives of successive waves of reformers, both clerical and lay.

While many acts of iconoclasm were conducted in an official capacity (MacCulloch, 1991, p. 12), the destruction of images provided an opportunity for religious expression for those who were not preachers, writers, or parish officials (Wandel, 1995). The consequences for this degree of subjectivity resulted in iconoclastic campaigns failing to purge all images from church interiors, as many openly survived or were spared by transformation and concealment (Tarlow, 2003, p. 111).

It has been observed that reformers drew a clear distinction between depictions of the things of God and the things of the world, with the latter providing a more acceptable criterion if one wanted to avoid breaking the Old Testament prohibitions against idolatry (Tarlow, 2003, p. 111). In regards to church fittings, special attention will be paid to the visual representations of a temporal nature, such as floral patterns which were essentially theologically neutral. Furthermore, the usefulness of certain depictions, such as figures from the Bible, may provide insight into a third distinction; things of the world that aided in the understanding of the things of God. As Scripture became more accessible and even gained a semi-divine status, iconoclastic acts during the Reformation were also an attempt to assert the preeminence of the Word, as text 
was superimposed over a defaced images or whitewashed surfaces (Graves, 2008, pp. $52-53)$.

The destruction of figurative iconography found on physical objects was tied to literally killing of people, which went beyond a mere ritual of 'killing things' (Hamilakis, 1998; Chapman, 2000; Graves, 2008, p. 36). As both historians and archaeologists have engaged with a medieval understanding of the body, a clear correlation between the body and iconoclasm provides crucial context to the damage and continues to aid in the dispelling the myth of blind or ill-informed destruction. This approach taken to the iconoclasm of figures was akin to an actual execution, as an offensive saint would suffer 'death' by beheading, for crimes against temporal authority, or burning, for crimes against the divine. The removal of a head stripped an image of its power and contextually suggested that the figure was guilty of some degree of treason (Graves, 2008, p. 40).

A targeted assault on the hands of images was tied to a bias against unacceptable rituals and practices, as the hands were requisite for the performance of acts such as the elevation of the host or even lighting candles (Graves, 2008, p. 43). Along with the head, hands possessed the symbolic life force of the figure and was even tied to their identity, as many saints were depicting holding a unique instrument or emblem. Iconoclasm of this nature reinforces the idea of the criminality being perpetrated by the images themselves.

This was an extension of the process of burning icons, which purified the object through reducing them to ash (Aston, 1993, p. 294). The approach was reserved for the most offensive icons believed to be imbued with true supernatural properties and worthy of being the centerpiece of a shrine, such as the Norfolk icon of Our Lady of Walsingham.

Iconoclasm stripped images of their enchanted properties, as it was revealed that a chisel or the simple application of paint or plaster was enough to suppress these objects thought to possess supernatural power (Koerner, 2004). The manipulation of these objects both structured and transformed these environments and impacted the 
relationship between parishioners and church fittings (Giles, 2007, p. 108). Moreover, the relocation of the communion table into the nave disrupted the traditional visual flow of a medieval church as the pulpit became the focal point of the space. Just as images were overwritten with vernacular passages from the Bible, these new floorplans expressed the centrality of the 'Word' over all else (Giles, 2007, p. 114).

\section{Question 2: Authority}

The transformation of power, governance, and authority in England during the Reformation can be observed in parochial settings through the destruction of icons and decoration chosen for new fittings. In addition, the 'structured' approach to reform, which retained an official hierarchy to the benefit of the central government, led to not only the emergence of a unique form of Protestantism but also an unprecedented intrusion of the state in local affairs.

Iconoclasm was instigated by agency from not only the central government but local authorities who promoted their own religious prerogatives, a desire for passive conformity or even an opportunity bolster their own prestige. Public and private acts of iconoclasm carried out by royal commissioners or local authorities were visual reminders to parishioners of not only theological changes brought by the Reformation but also the shift in power from the clergy to the laity (Aston, 1989).

Ecclesiastical authority was challenged and undermined, as the conflict between the Bible or Catholic tradition as the wellspring of theological power transformed the traditional religious paradigm. The void left behind allowed for the transference of institution power, as ecclesiastical authority technically became an extension of the royal prerogative. The strong Tudor proclivity for hierarchy, combined with the influential role of the cathedral within a diocese, resulted in the Church of England deviating from a reformed model of Protestantism seen elsewhere in Europe (MacCulloch, 2005, p. 75). In spite of the growth of reformed theology, the endurance of the prestige of the cathedral allowed it to function as a liturgical 'fifth column', in which the will of the Crown or clergy was imposed down into the parishes. As was evident by the introduction of Laudianism, new religious notions could be grafted onto 
a cathedral, even against its will, before flowing out to the local churches (Atherton, 2010, p. 896).

The issue of patronage is crucial while examining new fittings being installed throughout the Reformation, as every church possessed a patronage relationship with those in authority within the parish. Medieval parish churches were all built, renovated and outfitted through the patronage of wealthy benefactors for the good of their community, for their immortal soul and, of course, the prestige and demonstration of power. The Reformation brought a renewed emphasis on that last point, as the central government and local authorities needed to assert their dominance by implementing their coat of arms on existing and newly commissioned fittings.

The underpinnings the early modern state was forged by local officials who enforced the laws and social regulations resulting from the religious conflict brought about by the Reformation. This led to the state developing from the emergence of a middling tier of parish leaders, who were more connected to local affairs and in a position to actually enforce the will of the Crown. As a result, the state was not forged by the central government; rather, the by the governance of churchwardens, sheriffs, aldermen and other who held a narrow scope of authority (Hindle, 2000).

Additional considerations will examine the seeds of division between Crown and Parliament over sovereignty, the control exerted by the gentry in the country and the growing influence and importance of the municipal corporation over a wealthy urban region like Norwich. In other instances, the stance of the manor determined what happened in a rural parish church. All of these variables contribute to determining how the Reformation impacted different regions.

\section{Question 3: Identity}

A central element of the Reformation is the impact this period had on religious, regional and national identity in England. Within this context, practice theory suggests that religious identity predominantly emerged from both the daily practices and outward manifestation of the Roman Catholic Church. In this regard, it is challenging for archaeology to succeed in truly recovering identity alone, as material culture is an 
amalgam of various identities developed over an extended period (Meskell, 2006, pp. 23-44). Despite this, the structural component of a medieval Catholic identity is quite simple to examine, as agency was discouraged for daily practices in favor of subservience to rituals. As most of these practices required material culture, archaeology can still provide a composite of identity, regardless of its fragmented origin.

Modern identity theory recognizes that the current sociopolitical landscape of the world shapes the views of the archaeologist, thereby forming his or her interpretation of identities recovered from the past. While this opens up the possibility for a compromised objectivity of the researcher, modern sensibilities can help engage issues more relevant to our world than that of the subject. For example, gender, sexuality and class are identity concerns that inform the direction of modern scholarship, and thus shapes the prism in which the past is viewed. The motives for such an approach can be a noble attempt to access hidden corner of past identities; however, they are often spurred by a desire to instigate change in the present through the crafting of a broader narrative of the human experience (Jones, 2006, pp. 44-58).

Church fittings are ideal artifacts to observe as symbols of religious identity in the medieval world. As a result, the dramatic changes ushered in by the reformers provide a valuable glimpse at the transforming sense of religious, and therefore social, identity. This theme will also be key to understanding the differential impact of the Reformation on towns as opposed to the countryside. The issue is that the rural parishes are quite varied in terms of impact, as some will have a close connection to an urban center, while others are more isolated.

The Reformation transformed the way in which people saw and experienced the material culture of their parish churches. It has been demonstrated that the progression from medieval to modern was not linear, as people in each period had their own complicated and contradictory ways of experiencing and processing the images on display in their churches (Giles, 2007, p. 118). This type of material culture not only reveals changes to religious and cultural identities but also how local communities 
relied on physical plant of their churches to provide a sense of continuity with their past (Giles, 2007, p. 118).

Church liturgy was crucial in shaping and maintaining religious identity, as these rituals contributed to how people understood their role in society and as members of the body of Christ. For instance, baptism, and the role of godparents in the lives of parishioners provided a social and religious bond that was an integral component of local identity. It was a testament to the importance of this institution, that it endured the Tudor reforms relatively unchanged, with the only change being the removal of the prohibition of marriage between godparents and godchildren in 1540. Furthermore, baptism grew beyond a private ritual which created spiritual kinship and formal ties between families as it shifted to become a public event performed on Sunday before congregation (Coster 2002, pp 45-74). Although the institution of godparents was found not be vital by Puritans in the 1644 Directory for Public Worship, these expressions of religious identity were often still conducted until they were formally reinstituted following the 1660 Restoration (Coster 2002, pp 220).

\section{Question 4: Memory}

Memory has long been an area that archaeology has failed to provide any significant contributions to, in spite of it being one of the grand themes of both literature and history. 'Social memory' is a term used to describe collective traditions shaped and defined by a past shared by members of a community (Alcock \& Van Dyke, 2003). As a result, memory has a crucial role in the forging of the notions of identity and authority. In regards to the Reformation, it is important to take into account that memory is selective, subjective and thoroughly moldable in the face of propaganda and coercion. Furthermore, memory has an incredibly short lifespan, as forgetting is an inevitable conclusion resulting through the attrition of time.

Any study of the Reformation can benefit greatly from incorporating memory theory, as it contributes to three integral components of the processes undergoing during the 16 th and 17 th century. First, memory played an integral role within the local sphere of the parish in shaping which fittings survived, how they survived and in what form. In 
many cases, these fittings provided a liturgical and generational continuity, which connected people to their past in very real and tactile way.

Second, the visual motifs which survived, both damaged and undamaged, were part of an effort to forge new memory. Mutilation was more effective in shaping memory than complete removal of an image, as these constituted a new type of iconography that served a constant reminder of what had come before and what was no longer allowed. Thirdly, all reformers, both zealous and more restrained, wanted to purge the unacceptable remnants of their Catholic past from public life. While nothing could be done to prevent some of these practices from migrating into the homes of parishioners, extreme steps were required to facilitate the process of forgetting. While it was naïve and ultimately impossible, to achieve this within a generation, the potency of 'revisionist memory' which rewrote the collective memory, aided in driving a permanent wedge between most parishioners and institutional Catholicism.

The core mnemonic systems employed by the Church of England were built upon not only the introduction of Scripture as the theological basis of religion but also a sense of liturgical continuity that must have contributed to transition away from Catholicism at the local level. In regards to the latter point, church fittings became more than mere objects of religion, as they were imbued with a sense of memory that connected a parish across generations. For instance, whether a parishioner recognized the theological significance of baptism or not, they surely felt connected to their communal and generational heritage as the ritual was performed utilizing the same font that had possibly been used for centuries.

\subsection{Regional Approach}

\section{Choosing Areas}

The areas selected for this study were determined based on the social structures of Norfolk, which were shaped by the agrarian regimes that predate the industrial age in England and even Domesday (Tawney, 1912; Finch, 2000, pp. 7-8). Farming practices, dictated by the physical topography of the region, directly impacted the emerging social structures that developed throughout and beyond the medieval period. Therefore, three 
rural samples have been selected represent of the diverse ensuing communities and provide appropriate contrast with an urban sample.

The landscape of Norfolk can be divided into two general areas that possess varying topography and soil types. By the beginning of the seventeenth century, the northern and western regions of the county were described as having a very fine soil in which corn was grown in open fields. Sheep grazed on the grasslands by day and were shepherded to the fields to fertilize the ground by night to maximize this productivity of the land. These vast swaths of open land were usually controlled and operated by landowners who were able to institute social control through the manorial court system. The second region, the southern and eastern portions of the country, can be described as more haphazard with its unstratified soil deposited by a glacier; consists of sand, clay, gravel and boulders mixed and is far more wooded and possesses rolling and uneven topography. As a result, animal husbandry dominated the economy as the irregular landscape broke into more modest landholding parcels compared with the north and east (Thirsk, 1987, pp. 49-50; Finch, 2000, pp. 7-8).

Despite this relatively direct division, landscape historians now recognize that a more nuanced approach is necessary (Holderness, 1994). For instance, a clear subdivision emerges within the north-east soil paradigm as shrubland habitat can be found along with the fertile sand, silt, and clay composite. Recent work done on the countryside of East Anglia has defined the area that falls between these two distinct areas as the 'Northern Heathlands.' This landscape mosaic led to scattered settlement patterns and a complex combination of both larger and smaller landowning units, with an agriculture based on rye, wheat, and barley. Furthermore, a significant number of cattle were raised on the meadows in the river valleys. Due to the diverse landscape and agricultural practices, the area can be viewed as a microcosm of the county as a whole.

Tawney (1912) mentions that medieval Norfolk, and its neighboring county of Suffolk, accounted for the highest number of landholders in England, nearly double the national average. Furthermore, the importance of selecting Norfolk for a regional study, with national implications, can be seen through the fact that the county possessed a third of all landowners. The exceptionally high number of these liberi homines, or free 
landholders, can be attributed to more and more lords leasing out smaller parts of their demesne for increasingly longer periods of time. These factors contribute an important starting point for this study's approach to the rural parishes; despite the lack of prestige or social influence, the peasant class of landholders partially shaped agricultural life. Tawney draws attention to two special feature in regards to Norfolk. First, he suggests the vast social divide between agriculture throughout the rural areas of the county and urban mercantilism and manufacturing. While the latter lived at the mercy of market fluctuations, the former was primarily comprised of subsistence farmers which could be immune to such economics whims (Tawney, 1912, p. 111). Second, Tawney references the mention of an entry made of rent paid by "the inhabitants of the town of Scatsby (on the east coast of Norfolk) for lands occupied for their benefit" (Tawney, 1912, p. 206). He goes on to speculate that the commonly used term 'town lands' may imply a level of practical communism predating Marx. This strong claim is supported by the fact that at times the demesne lands were divided into precise and equal shares amongst the inhabitants, not with a convincing argument of documented cases demonstrating one tenant acting on behalf of the collective (Tawney, 1912, p. 112). Regardless of how common these practices were, a level of collective mentality, or lack thereof, needs to be acknowledged and will help inform any conclusions drawn about the how and why of religious reform in the rural parishes.

The agricultural regimes of Norfolk helped design the rural sample groups and heavily influenced the selection processes. Rather than attempt to draw arbitrary lines based strictly on something as abstract as the landscape, the boundary lines of the hundreds were utilized in establishing the three rural samples. A hundred in Norfolk, as introduced during the Saxon period, was the division of a shire for administrative, military and judicial purposes under the common law. While this system was succeeded by the formation of districts through England in 1894, the hundreds were still the only widely used legal intermediate between the parishes and the county during the period engaged in this study. The sample area representing the fertile sheep-corn will be referred to as $\boldsymbol{R}-\boldsymbol{N} \boldsymbol{W}$ and will comprises of every of every parish contained in the hundreds of: Brothercross, Freebridge, North Greenhoe, and Smithdon, including the market town of King's Lynn. The second sample region is based on the woodlands of the southern plateau with slight crossover into the dry sandy heath of the southwest. 
It will be referred to as $\boldsymbol{R}-\boldsymbol{S}$ and is made up of the parishes within the hundreds of Depwade, Diss, Guiltcross, and Shropham, including the market town of Thetford. The final rural sample is made up of diverse landscape found in the North Heathlands and the more fertile area to its immediate east. It will be called $\boldsymbol{R}-\boldsymbol{N} \boldsymbol{E}$ and consist of the hundreds of Blofield, South Erpingham, Taverham, and Tunstead.

The fourth and final sample group will contrast the three rural samples by examining urban parishes of Norwich, a city located on the River Wensum and the regional administrative capital and county town of Norfolk. This sample will be referred to as $\boldsymbol{U}-\boldsymbol{N}$. In the sixteenth century, the city had an impressive population of nearly 8,500 (McClendon, 1999, p. 2). It was one of the most populous urban centers in all of England, second only to London. In addition to being a prosperous commercial hub, the city was an important religious center with its cathedral and forty-six parish churches. Historian Matthew Reynolds (2005, p. 26) points out that this number was proportionally very high for a late medieval European city of lesser rank. To provide perspective, he cites Norman Tanner's (1984, pp. 2-3) comparison of Norwich in this regard to several continental European counterparts, such as Venice with 70 parishes, and Bruges with 12. As a result, the area was profoundly impacted by the Tudor reforms. Historian Patrick Collinson's (1982, p. 144) assessment of the city's Reformation history creates an idealistic portrayal of Norwich as a bastion of Protestantism. He claims that Calvinism saturated the city, and even likened the religious landscape to that of contemporary Geneva. He explains that a close union of civic authorities with Protestant theology, which was the envy of England in the late sixteenth century, is attributed to this phenomenon. It is an oversimplification to conclude that the reforms unfolded in these absolute terms. While the rapid alteration of religious life at Norwich can be attributed both to legislation birthed in London and local populist sentiment, the social, economic, and political factors of the region played an integral role in this process.

\section{Sample parishes}

The exact parishes examined in this study are listed in Table 1 to 4 and illustrated in Figure 6. Each of the three rural samples contains four hundreds and were chosen throughout the county in accord with the medieval agrarian regimes as defined by 
Tawney (1912). A selection of churches in each sample was visited, and each fitting was thoroughly recorded, with particular attention paid to its iconographic and liturgical significance. The position and continuity of the material, in addition to any traces of inflicted damage, was considered and documented. A photographic record was made where appropriate. Unvisited churches were thoroughly explored through documentary sources, including the National Heritage List for England (NHLE), the work of Sir Nikolaus Pevsner and the Churches of East Anglia website produced and maintained by Simon Knott. The NHLE is the official database for current information on all nationally designated heritage assets, including the interior of every parish church in Norfolk. Also, extensive use of the latest edition of Pevsner's Buildings of England architectural guide is a valuable resource for examining the contents of inaccessible churches or as a record for artifacts which have been lost over the previous half century since the work was first published. 


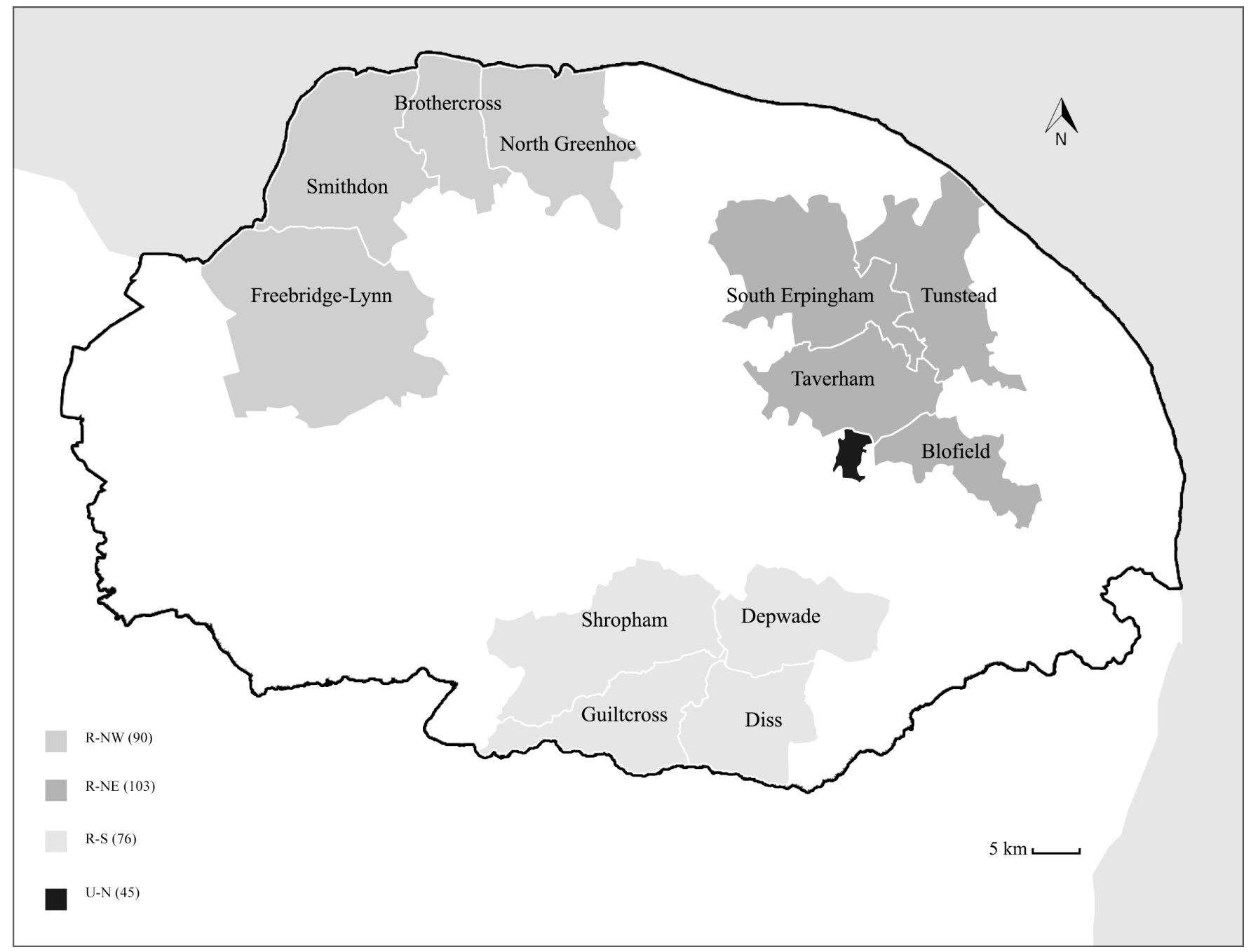

Figure 1: Norfolk Sample Groups \& Parish Totals (as of 1552) 


\begin{tabular}{|c|c|c|c|c|}
\hline Hundred of Brothercross & Castle Rising & Pentney & Hindringham & Docking \\
\hline Burnham Deepdale & Congham St Andrew & Roydon & Holkham & Fring \\
\hline Burnham Sutton & Congham St Mary & Sandringham & Houghton-in-Dale & Great Bircham \\
\hline Burnham Ulph & Dersingham & Setchey & Little Walsingham & Great Ringstead - St. Andrew \\
\hline Burnham Norton & East Walton & South Wootton & Quarles & Heacham \\
\hline Burnham Overy & East Winch & West Acre & Stiffkey - St. Mary & Holme-next-the-Sea \\
\hline Burnham Thorpe & Gayton & West Bilney & Stiffkey - St. John & Hunstanton \\
\hline Burnham Westgate & Gayton Thorpe & West Newton & Thursford & Ingoldisthorpe \\
\hline North Creake & Gaywood & West Winch & Little Warham All Saints & Little Ringstead - St. Peter * \\
\hline South Creake & Great Massingham & Wolferton & Warham St. Mary & Sedgeford \\
\hline Waterden & Grimstone & Hundred of North Greenhoe & Warham Blessed Virgin & Shernborne \\
\hline Anmer & Hillington & Binham & Wighton & Stanhoe \\
\hline Appleton & Leziate & Cockthorpe & Hundred of Smithdon & Thornham \\
\hline Ashwicken & Little Massingham & Egmere * & Barwick & Titchwell \\
\hline Babingley & Middleton & Field Dalling & Bircham Newton & Borough of King's Lynn \\
\hline Bawsey & Mintlyn & Great Snoring & Bircham Tofts & King's Lynn - St Margaret \\
\hline Castle Acre & North Runcton & Great Walsingham - St Peter & Brancaster & King's Lynn - St Nicholas \\
\hline & North Wootton & Great Walsingham - All Saints & Choseley & King's Lynn - St James \\
\hline \multicolumn{5}{|c|}{ * Lost or disused } \\
\hline
\end{tabular}

Table 1: R-NW Sample Group Parishes 


\begin{tabular}{|c|c|c|c|c|}
\hline Hundred of Blofield & Aylsham & Lammas & Felthorpe & Dilham \\
\hline Blofield & Baconsthorpe & Little Hautboys* & Frettenham & Edingthorpe \\
\hline Bradestone & Banningham & Mannington* & Hainford & Felmingham \\
\hline Brundall & Barningham Parva & Marsham & Hellesdon & Honing \\
\hline Buckenham & Belaugh & Oulton & Horsford & Horning \\
\hline Cantley & Blickling & Oxnead & Horsham St. Faith & Hoveton St John \\
\hline Freethorpe & Booton & Saxthorpe & Horstead* & Hoveton St Peter \\
\hline Great Plumstead & Brampton & Scottow & Newton St. Faith & Irstead \\
\hline Hassingham & Burgh-next-Aylsham & Skeyton & Rackheath & Neatishead \\
\hline Limpenhoe & Buxton & Stratton Strawless & Salhouse & North Walsham \\
\hline Lingwood & Calthorpe & Swanton Abbott & Spixworth & Paston \\
\hline North Burlingham St Andrew & Colby & Tuttington & Stanninghall* & Sco Ruston \\
\hline North Burlingham St Peter & Coltishall & West Beckham* & Taverham & Sloley \\
\hline Postwick & Corpusty & Wickmere & Wroxham & Smallburgh \\
\hline South Burlingham & Erpingham & Wolterton* & Hundred of Tunstead & Swafield \\
\hline Southwood & Great Hautboys & Hundred of Taverham & Ashmanhaugh & Tunstead \\
\hline Strumpshaw & Hevingham & Attlebridge & Bacton & Westwick \\
\hline Thorpe & Heydon & Beeston St. Andrew & Barton Turf & Witton \\
\hline Witton & Ingworth & Catton & Beeston St. Lawrence & Worstead \\
\hline Hundred of South Erpingham & Irmingland* & Crostwick & Bradfield & \\
\hline Alby & Itteringham & Drayton & Crostwight & * Lost or disused \\
\hline
\end{tabular}

Table 2: R-NE Sample Group Parishes 


\begin{tabular}{|c|c|c|c|c|}
\hline Hundred of Depwade & Stratton St. Mary & North Lopham & Scole & Hargham \\
\hline Ashwellthorpe & Stratton St. Michael & Quidenham & Shelfanger & Hockham \\
\hline Aslacton & Tacolneston & Riddlesworth & Shimpling & Illington \\
\hline Bunwell & Tasburgh & Rushford & Thelveton & Kilverstone \\
\hline Carleton Rode & Tharston & Snarehill & Thorpe Parva & Larling \\
\hline Forncett St Mary & Tibenham & South Lopham & Tivetshall St. Margaret & New Buckenham \\
\hline Forncett St Peter & Wacton & West Harling & Tivetshall St. Mary & Old Buckenham \\
\hline Fritton & Wacton Parva* & Hundred of Diss & Winfarthing & Rockland All Saints \\
\hline Fundenhall & Hundred of Gultcross & Bressingham & Hundred of Shropham & Rockland St Peter \\
\hline Great Moulton & Banham & Burston & Attleborough & Rockland St. Andrew* \\
\hline Hapton & Blo' Norton & Dickleburgh & Besthorpe & Roudham \\
\hline Hardwick & East Harling & Diss & Brettenham & Rushford \\
\hline Hempnall & Garboldisham St John & Fersfield & Bridgham & Shropham \\
\hline Little Moulton * & Garboldisham All Saints * & Frenze & East Wretham & Snetterton \\
\hline Morningthorpe & Gasthorpe & Gissing & Eccles & West Wretham \\
\hline Shelton & Kenninghall & Roydon & Great Ellingham & Wilby \\
\hline \multicolumn{5}{|c|}{ * Lost or disused } \\
\hline
\end{tabular}

Table 3: R-S Sample Group Parishes 


\begin{tabular}{|c|c|c|c|}
\hline St. All Saints Fybriggate * & St. Giles & St. Martin Balliva * & St. Peter Southgate * \\
\hline All Saints Westlegate & St. Gregory & St. Mary Coslany & St. Saviour \\
\hline St. Andrew & St. Helen & St. Mary in the Marsh * & St. Simon and Jude \\
\hline St. Augustine & Holy Cross * & St. Mary the Less & St. Stephen \\
\hline St. Bartholomew * & St. James & St. Mary Unbrent * & St. Swithin \\
\hline St. Benedict $*$ & St. John and the Holy Sepulchre & St. Michael at Plea & St. Vedast \\
\hline St. Botolph * & St. John the Baptist Maddermarket & St. Michael at Thorn $*$ & St. Peter Southgate \\
\hline St. Clement Colegate & St. John the Baptist Timberhill & St. Michael Coslany & St. Saviour \\
\hline St. Edmund & St. Julian & St. Olaf Pitt Street * & St. Simon and Jude \\
\hline St. Edward * & St. Laurence & St. Paul * & St. Stephen \\
\hline St. Etheldreda & St. Margaret Westwick & St. Peter Hungate & \\
\hline St. George Colegate & St. Martin at Oak & St. Peter Mancroft & \\
\hline St. George Tombland & St. Martin at Palace & St. Peter Parmentergate & \\
\hline
\end{tabular}

Table 4: U-N Sample Group Parishes 


\section{Distribution}

Materials in each instance are divided into three chrono-contextual categories, providing the framework for the three primary content chapters of this work. The first category will examine materials that predate the start of the Reformation, as defined in the 1534 Act of Supremacy. The second category is surviving fittings that fell victim to acts of deliberate iconoclasm. These two categories share a significant commonality, as most cases of iconoclasm are defaced medieval survivals. Third, materials produced between 1534 and the Restoration of 1660 comprise the final grouping. The assessment of these three categories takes into account evolving religious traditions unfolding against an equally complex political backdrop. A detailed analysis of decorative subject matter of all recorded artifacts will be examined across case studies for parishes found in all four groups.

The data compiled in this study outlines a chronology of survival, destruction, replacement and restoration of church fittings within a new context. The following chapters will describe the process in detail, but it may be advantageous here to address several general points. The rates of survival for each fitting appear to be similar across the three rural samples and even the urban sample of Norwich. A common finding throughout the four samples is which particular fittings tend to have very high survival rates. For instance, font, screens, glass and paintings all have impressive survival rates within each sample.

Each chapter is subdivided by specific fittings and further subdivided by sample. This approach will allow a very granular approach to analyzing the data and engaging the research aims while enabling informed conclusions to be drawn throughout the work before coming together at in a detailed discussion found in Chapter VII.

\section{Case study criteria}

This study will account for every fitting and furnishing contained within the interiors of the aforementioned samples. In select cases, a detailed examination of an artifact has been conducted in an attempt to engage all of the research aims mentioned above properly. Items that received special attention and will be assessed in detail are: 
baptismal fonts, screens, wall paintings, and sculptures. While this does not reflect the extent of the data to be compiled and discussed, it represents the dominant furnishing and fittings that tie directly into issues of visuality, spatiality, and liturgy. That being said, dependence on a small number of cases does not provide the opportunity to properly engage the core of an argument or draw broad conclusions. In order to circumvent this potential criticism, the represented cases will always be tightly integrated into the more comprehensive quantitative data being assembled from the larger samples. Through this process, a nuanced context blended with the wider generalizations will aid in arriving at comprehensive conclusions. Any archaeological assessment of the Reformation needs to strike a balance between the two if it hopes to engage the social and religious upheaval of the period adequately.

\subsection{Physical Dataset}

This study primarily uses the assessment of church fittings and spatial analyses to investigate the research questions outlined earlier in the chapter.

An extensive database of all fittings has been assembled using Microsoft Excel and includes information on the parish, church, period, position, purpose, iconographic depictions and the Ordnance Survey (OS) National Grid coordinates. Furthermore, additional data, such as monuments and exterior fittings, were also documented. This database assembled with information accessed from the Buildings of England series by art historian Sir Nikolaus Pevsner, Guide to Norfolk Churches by DP Mortlock and CV Robert and the National Heritage List for England. In addition, this list was supplemented by field research conducted for this study and references to lost fittings supplied by churchwarden accounts and An Essay Towards A Topographical History of the County of Norfolk by Francis Blomefield.

\section{Choosing furnishings}

This study examines a series of medieval and early modern ecclesiastical interior fitting, furnishings and fixtures. These artifacts will be divided into three categories: sacramental, decorative and functional. Based on survival rates, special attention has been paid to baptismal font, screens, wall paintings, sculptures, and communion rails. 
Furthermore, an in-depth analysis considers the impressive collection of sculpted roof bosses located in the nave, chancel, and cloisters at Norwich Cathedral.

The fittings selected were specifically chosen for either their strong liturgical or decorative significance. Baptismal fonts, modified rood screens, communion rails and pulpits were still requisite for conducting the parochial rituals. The exclusion of stained glass windows came about late in the research, as their practical importance for safeguarding the building interiors from the elements may have played a more integral role in any survivals beyond any religious compulsions. On the other hand, their delicate composition could have also resulted in accidental or unsanctioned damage that again does not provide the context needed for this particular study. Instead, wall paintings and statues were selected as the function of these forms of decoration were not liturgical and did not impede a church from administering the remaining authorized sacraments. While it was believed that these images were a conduit to God, the patronclient component of veneration was denied by Reformation theology and thus not requisite for effectively serving a parish (Graves, 2008, p. 39).

The omission of funerary monuments from this study should not suggest that the value of these fittings in an analysis of authority, identify, memory and even iconoclasm. Rather, the archaeology of commemoration warrants future research which builds upon previous studies with a detailed examining the changes in theology and social class reflected on the forms of decorations chosen to memorialize the dead (Finch, 2000).

All case studies were selected based on the accessible of buildings, the inclusion of a relevant fittings, and preferably an iconographic depiction on the fitting being examined. If and when a site was not reachable, secondary sources and photography were relied upon and often more than adequate in examining the design or decorative motifs. In these case, the central limitation was the inability to always discuss the fitting within its proper spatial context, as the precise location of the object within the building could not always be ascertained.

During the summer of 2010, the following churches were visited in Norwich as part of data compiled for an MA dissertation (Ladick, 2011): St John de Sepulchre, St Peter 
Parmentergate, St Peter Mancroft, St Augustine, St Gregory Pottergate, St Stephen, St Andrew, and Norwich Cathedral (include the chapel that houses the former St Mary in the Marsh). The fieldwork for this study began in August 2012 with visitations to select churches from the $R-S$ sample were visited: Aslacton, Attleborough, Blo Norton, Bridgham, Dickleburgh, Garboldisham, Shimpling, and Tivetshall. The second phase was conducted in Octover 2013, as the following church from the $R-N W$ sample were visited: Binham, Burnham Deepdale, Cockthorpe, Dersingham, Docking, Gayton Thorpe, Hunstanton, Thornham, and King's Lynn St Nicholas. The final truncated phase of fieldwork concluded in November 2014, as churches from the $R$-NE sample were visited: Burgh-next-Aylsham, Cawston, Colby, Irstead, Sloley and Rackheath.

Case studies were also chosen based on the evidence being consistent with the broader data trends being presented in regards to the different fittings and iconographies. For instance, if a defaced painting of a rare extrabiblical saint is selected for a case study, the damage to an image of this nature is typical even depictions of that particular saint is atypical.

\section{Considering survivals}

Chapter IV engages with the four sample groups and examine church fittings that predate the Reformation and survived any deliberate defacement or destruction. It is argued that the survival of medieval fittings can be classified into four general categories. Firstly, the surviving artifacts did not offend the theological imperative of the reformers. While not many icons fall into this category, several trends begin to emerge once the survivals are observed within the context of the new beliefs being propagated throughout the Reformation. Secondly, the surviving materials were hidden and spared from the various waves of iconoclastic activity; a testament to the complex religious landscape, which was present in every phase. This category can be further divided into two subcategories. The first is icons which were actively hidden. Artifacts of this nature were concealed in the walls, buried, continued to be used in secret, or even reused to serve a new purpose. The second is icons which were accidentally preserved, such as whitewashed wall paintings. While this chapter will examine icons from the first subcategory, the following chapter on iconoclasm will discuss discarded or suppressed survivals. Thirdly, certain survivals were still needed 
for the liturgy. The most prominent example is the high survival rate of fonts. While most of the sacraments were abolished, baptism endured as a crucial element of Christian life. This can be attributed to the repeated mention of the ritual laced throughout the New Testament. Survivals of this nature would often be transformed, altered, or even reused. Finally, many remaining artifacts appear to have endured as a result of the impracticality of removal.

\section{Considering iconoclasm}

Chapter $\mathbf{V}$ examines any deliberately defaced or damaged survivals that either predate the Reformation or new fittings that predate the Restoration of 1660 . The formal rejection of idolatry during the Reformation had a severe impact on church fittings in Norfolk. The removal of the ornamentation of the religious buildings represents the destruction of a significant portion of the material record. While the removed and destroyed icons are not available for physical assessment, many damaged, discarded, and defaced artifacts have survived. As a result, a systematic analysis of these objects provides greater context for the period.

Any assessment of iconoclasm can fall victim to the uncertainty of the conditions by which the material record was altered or destroyed. Furthermore, successive waves of iconoclasm and refitting took place during the sixteenth and seventeenth centuries. The government of Edward VI escalated the rate of material and doctrinal destruction during its brief tenure. The reemergence of Catholicism under Mary I, and subsequent religious compromises enforced by Elizabeth I, make it difficult for archaeologists to draw an absolute conclusion on the iconoclasm of the period.

\section{Considering new furnishings}

The historical archeology of the Reformation often succumbs to the temptation of becoming merely a study of the deliberate destruction of the material record. However, a subsequent analysis of the devolution of spatial sacrality can focus on the conventions, beliefs, and ideals lost during the tumultuous transition. While the importance of the survival and destruction of religious fittings and furnishings in Norfolk is the core of this study, it is just as crucial to access the materials produced throughout the Reformation. Two distinct styles emerge as a result of the religious 
divisions taking place. First, a utilitarian vogue developed in response to new Protestant theology taking root in East Anglia; these materials were quite simple and often understated. Despite the continued need for select fittings, such as baptismal accessories and communion tables, the importance of the objects themselves had diminished. Secondly, new furnishings that glorified and promoted ceremony and ritual were observed in the record during the period. In these cases, elaborate refittings were installed to replace items that fell victim to wear, tear, or iconoclasm. In the mid-sixteenth century, Catholic paraphernalia reemerged as Mary I attempted to reunite her kingdom with Rome; however, the subsequent rule of her half-sister Elizabeth reversed many of these strides for the remainder of the century. By the seventeenth century, High Church fittings of this nature reflected the desire to reintroduce ceremony and ritual into the Anglican faith, which reached its crescendo under the archbishopric of William Laud (1633 - 1645). In addition to the new fittings found throughout the city, Norwich possesses an impressive collection of postReformation funerary monuments, which further suggest the transformation of societal priorities from the Church to the state and individual (Finch, 2004).

\section{Limitations}

In all cases, access to the surviving parish churches was enough to carry out the case study research. The case studies were chosen from the samples, with adequate distribution and logistical access to the buildings; however, several problems arose which are inherent to an archaeological assessment of the Reformation. First, the study of iconoclasm is a fragile enterprise as defaced or damaged artifacts were unlikely always to endure, however, this very destruction was also the salvation for many icons in the case of painted images, which were whitewashed. Secondly, the Victorian restorations, a nineteenth century Gothic Revival driven by the Cambridge Camden Society and the Oxford Movement, make it tough to uncover medieval or early modern fittings. These building restorations were thought to revive pre-Reformation sensibilities in an attempt to curb declining attendance (Mari, 2010, p. 7); however, these modern medieval veneers led to the loss of much of the post-Reformation material fabric while mudding a surface assessment of the church interiors. As a result, any surviving fittings found at a restored church cannot ignore this late period 'filter', shaped by a modern attempt to impose medievalism artificially. Thirdly, the precise 
dating of particular artifacts is often challenging and makes it hard to determine at which phase of the Reformation a new fitting was created. It quite difficult to factor in negative evidence of iconoclasm, as the loss of an uncommon church fitting not referenced in the documentary record would not be known to an archaeologist (Giles, 2007, p. 113). Finally, many of the medieval parishes under observation either no longer exist, have had their structures converted or were more recently gutted by wartime destruction. While these issues prevent granular results in some instances, they will not inhibit general conclusions from being drawn which will support the detailed and precise findings.

\subsection{Documentary Resources}

Documentary evidence was consulted to aid the analysis, and in many instances has bolstered and enhanced the results of the physical dataset. This section briefly discusses the historical resources that have been utilized, alongside some discussion of their limitations and biases

\section{Primary Sources}

Churchwardens' accounts provided by the Norfolk Records Office (NRO) were used extensively to investigate the fittings of each parish church. In addition to being a detailed log of all expenditure made to upkeep the physical structure of the building, these accounts also record the maintenance, repair, and interior replacement of fixtures. Primarily, these sources are formatted as an annual ledger. While the rate of survival of these documents is intermittent, 1534 through 1660 were used as the boundaries of analysis. In all cases, the accounts were transcribed from their original secretary hand with special attention paid to the years surrounding key events, such as: the five royal ascensions; the Henrician Acts of Supremacy, the Edwardian injunctions, the Elizabethan settlements; the archbishopric of Laud, and the Civil Wars.

Inventories of Norfolk Church Goods was compiled by a Commission appointed by the Privy Council under Edward VI in May 1552. The condition of church property was recorded, with the adherence to the new religious injunctions noted. While this process covered all of England, the inventories for Norfolk are mostly intact and available from 
the NRO and transcribed across several volumes of Norfolk Archaeology (Norfolk and Norwich Archaeological Society, 1846-)

Another documentary resource utilized is the seventeenth century journal of William Dowsing. Dowsing was a Suffolk-born iconoclast who commissioned the destruction of monuments of idolatry and superstition as defined by a Parliamentary Ordinance of 28 August 1643 (Cooper, 2001, p. 2). The rural comparison will enable this study to examine the career of Dowsing and his iconoclastic activities in East Anglia, and compare portions of his known itinerary with the actions of any commissioners assigned to Norfolk.

Finally, wills from the period under review were consulted in an attempt to extract any passing mention or proximity reference to a surviving fitting. While this resource does not offer significant data for this study, the possibility of their usefulness could not be discounted. Ancient Funerall Monuments (1631) by antiquary John Weever was also consulted for any possible references to interior fittings. However, as mentioned previously, this study will not retread the impressive work on funerary monuments already completed by Finch. Bishop Joseph Hall's 1647 account of iconoclasm at Norwich Cathedral was also referenced.

\section{Secondary Sources}

An Essay towards a Topographical History of the County of Norfolk compiled and published by the English antiquary Francis Blomefield, and completed by various successors throughout the eighteenth century, will be referenced extensively throughout this work (Blomefield, 1805 - 1810). Making use of antiquarian Peter Le Neve's (1661-1729) ordinary collection of materials for the history of Norfolk as a base, the work is extraordinarily detailed and provides information on nearly every parish church in the county. This assessment of the churches also makes explicit references to funerary monuments, which at times makes passing references to other furnishings located nearby. This provides a valuable window into a period post-dating this study but precedes the extreme alterations that many churches underwent during the Victorian age. 
The National Heritage List for England (NHLE) is the official database that provides authoritative information on all nationally designated heritage assets in England. For this study, the comprehensive list of buildings provided a starting point for determining the assets contain within each structure. Despite the extensive nature of this data repository, the necessity to supplement the inventories compiled with fieldwork and additional documentary sources was required for the quantitative analysis.

The Buildings of England were originally compiled and published by art historian Sir Nikolaus Pevsner between 1951 and 1974. These works are a comprehensive series of guidebooks to architecture in England, which provide general information of the interiors of every surviving parish church in Norfolk (Pevsner \& Wilson, 1997, 1999). This resource was used to supplement the data acquired from the fieldwork and the NHLE database. Furthermore, the guide provides valuable insight and data on any artifacts lost during the half-century, along with the occasional mention of fittings that may have been lost during the destruction of WWII.

\section{Limitations}

There are various problems with the documentary evidence examined in the research, particularly within the churchwarden accounts. Primarily, the majority of the limitations relate to the completion, manuscript quality and availability of the reports. While they provide valuable data and insight, roughly only $5 \%$ of the samples have surviving accounts from the period, all which have been transcribed.

The richest secondary source available to this study also possesses several limitations. Francis Blomefield's systematic assessment and inventory of church monuments was not conducted with the same rigor or detail as the work completed by his successor, Rev. Charles Parkin. Furthermore, subsequent volumes were not even completed by Parkin, but by a bookseller's hack employed by Whittingham of Lynn (Lee, 1886, p. 227). 


\section{Chapter III: Literature Review}

The previous chapter outlined the research question and themes designed to determine how various church fittings survived in the form they do, along with the methodology and sources utilized to engage them. This chapter provides a brief review of the historical and archaeological literature of the Reformation, including the dramatic shift in consensus resulting from the implementation of superior historical methods in recent decades. As this 'revisionist' position demonstrated that English Catholicism was both popular and vibrant on the eve of the Reformation, subsequent historical work has addressed issues such as sacrality, the notion of a long Reformation that extended into the following century, a pluralist Protestantism, and broad support for social stability above personal religious preference. Furthermore, this section will provide a brief overview of recent archaeological scholarship of not only iconoclasm, authority and identity, but also public worship, private devotion, the dissolution of religious institutions and commemoration.

\subsection{History}

\section{Popular Reformation}

The religious experiences of parishioners in England during the Reformation has been the primary concern for those investigating the period and seeking to understand how the events unfolded. Historical scholarship, and later archaeological evidence, has steered the conversation away from only engaging with the affairs of those in power. Instead, modern research has sought to tie these national narratives into a broader tapestry, which includes both local authorities and the everyday people. The inclusiveness of this approach has added a nuanced richness to our understanding of the Reformation, which unfolded differently across various sect of English society.

The traditional paradigm in Reformation studies held that the break between England and Rome was the political culmination of widespread religious malcontent that placed the country on an irreversible trajectory towards Protestantism. While the momentum of the process was interrupted by the Catholic reign of Mary I, it was believed that her 
predecessors had irrevocably vanquished and vilified the old faith. This position is an example of Whig historiography, which attempts to demonstrate that events in the past were an inevitable march towards greater liberty and enlightenment; therefore, ultimately manifesting in the present as liberal democracy and constitutional monarchy. Using the city of York as a case study, historian A.G. Dickens offered a more sophisticated understanding of this process in his publication The English Reformation. It was argued the popular appeal of Protestantism, either in support or in spite of the royal and parliamentary decrees spilling out of London. In this estimation, Protestantism had broad support amongst a populace hungry for reform and a new form of religious expression (Dickens, 1964). Despite this attempt to infuse rigorous historical research into the Whig position, a revolution in thought and new findings were about to realign the debate and restore the reputation of late-medieval English Catholicism.

These views were reinforced by work done on the state, as it was suggested that the abolition of Catholicism was achieved by the middle of the $16^{\text {th }}$ century through effective governing and widespread hatred for a failed ecclesiastical apparatus (Elton, 1972). The corruption and poor administrating of the Church had failed to meet the spiritual demands of the realm, resulting the need for the laity to take control of religious affairs and assure that the clergy would be specialize profession capable of effectively performing their duties (Elton, 1977, p. 371).

\section{An Imposed Reformation}

A backlash against the traditional perspective ensued beginning with Christopher Haigh's work conducted in Lancashire. This revisionist approach contended that Roman Catholicism was both vibrant and popular in the region on the eve of the Reformation. Furthermore, Haigh provided evidence for widespread resistance to Protestant doctrine throughout the remainder of the century throughout each successive Tudor reign. This research spilled from the confines of Lancashire to be more fully developed as a countrywide model for the impact of the Reformation. Haigh (1993, pp. 16-17) explains that this new approach, in addition to being supported by parish records, helped create a more balanced angle of view when examined in conjunction with the traditional Whiggish perspective. The excessive claims of ecclesiastical 
corruption made by figures like Thomas Bilney and Hugh Latimer, and the successive statutes carried out, against clerical abuse, the authority of Rome, and the monasteries, only show one side of the argument and the indisputable results. It becomes equally important to examine church documentation, such as churchwarden accounts, last wills, and visitation reports, to understand what religious life was really like at the start of the Reformation.

Rather than the period being viewed as a singular event, the Reformation was now seen through a more granular lens, as a series of interconnected policies being ushered in on political, as opposed to social or even economic, grounds. This new approach, especially in relation to the Henrician reforms, was very consistent with the argument that Thomas Cromwell, chief minister to Henry VIII, was the architect of a modern, bureaucratic government that replaced the medieval, household government (Elton, 1953). In this view, the personal Protestant inclination of several key political figures was the catalyst to push political and religious reform on a nation that was content and fulfilled by their traditional faith.

It has been argued that the crucial first generation of Christians to endure the Reformation conformed for the most pragmatic of reasons; they did not want to have their lives ruined by the state whilst enough elements of their traditional faith were still present on Sunday mornings. Although religion was still very much a central component to their cultural identity, the stakes were far too great as the sacramental works associated with salvation still endured on some level. The importance of retaining both Baptism and the Eucharist pacified an entire generation in popular indifference, which avoided a civil uprising where the common parishioners would be fighting for their very souls.

The model put forth by Christopher Haigh (1993) is an admirable effort to categorically define the various popular forms of Christianity to emerge from the Reformation. While religion was still a central element of English cultural identity, the level of commitment varied while providing a passive method of religious participation which did not require any degree of understanding of one's faith outside of receiving the sacraments and exhibiting decent living. While more advanced paths did exist for the 
laity, such as joining religious guilds, Protestantism provided a new scheme which required a contemplative comprehension of the justification by faith doctrine; fueled and fed by the absorption of the Word. Haigh discusses how popular piety was shaped by lay manuals; first by Richard Whitford for Catholicism in 1530 and later William Perkins for Protestantism in 1580 (Haigh, 1993, p. 287). The latter promoted the new Christian framework where salvation was not earned through works; rather, it was attained through an informed faith, influenced by the Holy Spirit and bolstered through the Word. The churches in Norfolk demonstrated that transformation of habitual adherents into thinking believers did not always require the removal of distracting images. Instead, these icons could be pruned to promote, and even enhanced, the Word-centric theology which could not always be compatible with widespread illiteracy. Instead, these images could provide a bridge between the two worlds, visually informing the congregations of what was acceptable and what was unacceptable.

The reality of the Reformation is inherently tied to the fact that a majority of the laity in the sixteenth century did not alter the core paradigm of their salvation; even as the scheme of worship was utterly overhauled and notion of purgatory was abolished. The personal and introspective faith promoted by the diehard reforming evangelists was a double-edged blade; as that same introspection could easily result in faith-based exterior disguising a works-based interior. After all, the Church of England provided enough of a liturgical and hierarchical infrastructure to foster this duality; regardless of its actual doctrine. While Biblical images, and select liturgical furnishings, endured at an impressive rate across all four sample groups, this may have also enabled habitual Christians to embrace a perspective that the meaning of faith had not really changed. This interpolation of the old onto the new helped shape the next wave of conflict, as this hybrid approach to faith prevented a true religious reformation in the eyes of some.

By the late sixteenth century, four distinct types of Christians existed in England; both firmly entrench within the establishment and operating on the fringe; godly extremists, recusant papist, and old Catholics group. The fourth group, fueled by widespread conformity, were parish anglicans; those who attended Church of England services with neither the zeal of the godly or the staunch resistance of the papists. These 
'lukewarm' Christians comprised a majority of the laity, with their true intentions ranging from either indifference to retaining their traditional works-based interpretation of religion (Haigh, 1993, pp. 292-293). This group, the passive and disinterested engine of the Reformation, appear have been the residue of those other group. They were despised by both the godly, who desired reform to transition into revival, and the papists, who saw them as cowardly traitors to the one true pathway to salvation.

The results of this study have uncovered a common thread between the godly extremists and conformists existing within the parish churches; an endurance of medieval iconography depicting figures and events from Scripture. For some of the godly, these images could represent historical commemoration, as opposed to veneration, and provided a gateway to a popular understanding of the Bible and true theological revolution to capstone the Tudor political reformations. For the conformists, these images provided a visual continuity that eased both their religious capitulation to the central government and the new doctrine that went along with it. This commonality contributed to both the success of the Reformation while laying the foundation for the seventeenth-century wave of conflict between Puritans, who believed England was ready to rely on Scripture alone and the conformists who were allowed to have their medieval sensibilities evolve into a desire for a Catholic-lite state church.

New revisionist historians emerged in the following decades to reinforce the new paradigm and continue to characterize Protestantism as an unwelcomed interloper being forced upon a resistant populace. Historian J.J. Scarisbrick's work on the period characterized the Reformation as a process that was met with turbulent resistance until it was slowly and grudgingly accepted, as late as the early seventeenth century. His 1984 publication entitled The Reformation and the English People went a step further than Haigh in its attempt to strip the key Protestant figures, such as Thomas Cromwell, of even their political achievements. Scarisbrick challenged Elton's work by suggesting that the 'revolution' in Tudor government engineered during Henry VIII's reign was far from the innovative milestone it had previously been heralded. 
In the face of the new orthodoxy in Reformation studies, many revisionist historians found themselves personally under attack, as a correlation was often made between their sympathies for the traditional religion and their own Catholic faith (Robinson, 2011). This is, of course, an underhand tactic to discredit a perspective, as the historical work should come under fire, not the historian himself or herself. This work will ever be mindful of engaging the arguments and never the individual.

The shift in orthodoxy ushered in by the revisionists has further shifted recent research away from the eve of the Reformation and towards analyzing the logistics of how England was transformed into an essentially Protestant state following the religious settlements of 1559. A consensus of the chronological conclusion of the Reformation has not been reached. Some historians, like Dickens, see the Elizabethan settlement as the triumphant conclusion to the story, while other content that Anglicanism was not generally accepted for at least another two decades. The revisionists, like Haigh, dispute this view and argue that despite the Protestant trappings of the new English religion, the people had yet to be completely won over until well into the seventeenth century. While popular Catholicism appears to have been driven from the minds and hearts of men and women by this time, this study will extend its reach beyond these earlier dates and include the Civil War through to the Restoration as an extension of the process of 'reformation,' if not in theology, than in inclination and trappings.

The first prong of the revisionist argument contends that many of the allegations of unpopularity leveled against the Church, stemming corruption and superstition, have been greatly exaggerated. The landmark publication The Stripping of the Altars by Eamon Duffy (1992) transformed this position as it extended far beyond the normal use of documentary evidence and incorporated the surviving material fabric of parish churches, such as screens and windows. One of the primary causes for the vibrancy of late-medieval Catholicism lied in the relatively uniform understanding and expression of faith across nearly every level of society (Duffy, 1992, pp. 2-5). While the wealthy, and members of the clergy, had access to a broader array of religious material, the gap between the literate and illiterate was bridged through religious education, both clerical and lay, visual representations and sermons within the parish churches, rhyming songs, and even plays. It is inaccurate to suggest the lower classes were rife with paganism 
and witchcraft, as opposed to merely being a less informed cross-section of the population who still knew the basics, such as about Christ and the sacraments, and lived by the official orthodoxy.

Examinations of the Counter-Reformation instituted during the turbulent reign of Mary I (1553-58) tends to only focus on the negatives of the period, such as the unpopular Spanish marriage and the brutal treatment of Protestants (Duffy, 1992, p. 254; Duffy, 2009). Instead, the prospect of a Catholic restoration was quite popular in its time, as the policies Cardinal Reginald Pole were informed by the official strategies being developed at the Council of Trent, while uniquely applying them within an English context. These reforms extended beyond a mere return to the traditional faith, as it sought to address many of the grievances being leveled against the Church preceding England's break with Rome. These countermeasures went as far as to graft acceptable Protestant virtues into Catholicism, including daily clerical preaching, and key prayers being recited in the common vernacular. Furthermore, the bishops were instructed to make sure that their clergy was literate, learned the scriptures and were capable of preaching. In the event the parish clergy was unable to preach, they were given Profytable doctrine (Bonner, 1555), which outlined the catechetical fundamentals of the Catholic faith, including all creeds and the seven sacraments. This valuable publication provided clergy members, who were unable to develop their own proclamations, everything they would require to fulfill catechetical programs (Duffy, 1992, p. 534). This position realigns all previous analyses of the Marian reforms, in full opposition to the Whiggish portrayal of a brief, and unpopular, CounterReformation destined to fail.

Haigh agrees with Duffy's assessment of how important Pole's policies were in reshaping England. In many ways, Pole began to institute policies that anticipated the Protestant condemnation and reform decrees resulting from the Council of Trent, which embodied the Catholic tenets of the broader Counter-Reformation. The ordination process became far more rigorous, with testimonials of piety and compassion becoming a requirement. Sunday sermons and feast days were made requisite and enforced through visitations of the bishop. As a result, all new appointees were theologians, while many of the older lawyer-style members of the clergy transformed into energetic 
pastors. He also notes the unique English method of Counter-Reformation, which declined an offer from Ignatius Loyola to send Jesuits to aid the process. This demonstrates that the Marian Church, under Pole, recognized a level of inherent xenophobia amongst the populace of England and did not want any foreign influences to pose as a potential disruption to the process (Haigh, 1993, pp. 224-25).

Revisionists have added a complexity and nuance that is far more compelling than the bland trajectory of destiny put forth in the Whiggish view. The Reformation occurred in spite of a plethora of conditions, and the ultimate triumph of Protestantism was contingent on even more. That being said, their arguments culminate with an incomplete sense of how and why such a cultural upheaval could be possible in the face of such broad resistance. One of the finest clues and examples we have comes from the reluctant conformity exhibited by Christopher Trychay, a priest in the small parish of Morebath from 1520 to 1574 . Despite the new religious doctrine being in conflict with his personal inclinations, Trychay conformed to the Elizabethan Settlement, just as he had conformed to every shift in policy since Henry VIII (Duffy, 2001). Ultimately, Duffy's work on Trychay demonstrates that duty and honor to his parishioners, and obedience to his monarch, were powerful enough to transcend the debate over religious doctrine.

A post-revisionist perspective begins in the closing attempts that revisionists made to offer some level of closure to their portrayal of the Catholic Church before and during the Reformation. Duffy proved in his work that people were not complacent when it came to their faith, as it was an active, and crucial, component of their lives. The question left to us in the wake of a Haigh and a Scarisbrick is: how and why did England succumb to a religious revolution that no one wanted? Furthermore, another question remaining is when the Catholic/Protestant portion of the debate was essentially put to rest in favor of the successive High Church Anglican/Puritan conflict. Haigh (2001) realigned his position slightly and accepted that by the reign of James I, the official Anglican orthodoxy had succeeded in educating the general populace of its catechism. 
Revisionists do offer some broad answers to these looming inquiries, such as Duffy's explanation that the popularity of the 'traditional religion' was no match for the political machinations of the Tudor government, with the selling of the monastic lands being a difficult obstacle for any Catholic revival to have to overcome. He also mentions that the lack of a thriving domestic clergy, combined with the absence of extensive mendicant orders, made England vulnerable to the anti-papal sentiment being fueled and reinforced by the growing anti-Spanish feeling taking root in the wake of Mary's reign (Faul, 1994, p. 277). Certain historians, like Phillip Hughes, laments that Cardinal Pole had been kept out of England by Spanish diplomacy until after the marriage between Mary and Phillip II had taken place. Hughes argues that Pole's superior understanding of religion, within an English context, would have foreseen that the people of England would not accept the rule of a foreign monarch in exchange for a return to Catholicism (Hughes, 1953, p. 221). While revisionists often considered the 'high political' arguments flawed, the validity of this view cannot be dismissed and is consistent with many of the revisionist's core positions (Faul, 1994, p. 277).

Patrick Collinson (2002) offers a brilliant analogy that calls into question the true nature of piety amongst the generation of Catholics who allowed their faith to be overturned. He compares the abolishment of chantries and the doctrine of purgatory in 1540 to a twenty-first century citizen discovering that the government has seized his or her retirement pension and rendered it worthless. The fury of the population of in the face of such an outrage would be difficult, if not impossible, for a government to carry out; therefore, this riddle of compliance opens the door to uncover answers as to what actually transpired. Collinson hints at the direction that this study will take when he questions the definition of the word 'Protestant' and suggests that a further reaching interpretation may be required. Henry VIII, despite his personal beliefs on the matter and prescribed mode of worship, sacrificed his right to call himself a 'true' Catholic when he chose to break with Rome. The same goes for everyone who bent the knee in submission to the new orthodoxy. The term 'Protestant' needs to extend beyond its narrow delineation, which invokes imagery of radical Puritans desecrating holy shrines and defacing iconography in hatred for 'popery.' Moreover, the common threads of Christianity will be the key to developing a more sophisticated understanding of 
England moving from true Catholicism to successive and varying forms of Protestantism.

Post-revisionism has two paramount things to offer as we move forward in answering the question of how and why the Reformation occurred. First, we must be cautious in allowing our sympathies to shape our view of the past, a charge leveled first at Whig historian, who in most cases were Anglicans, and later at revisionists, who in many cases were Catholic themselves. Haigh (2002) mentions that the historiography of the Reformation now needs to be rescued from the Catholics, just as the revisionists had saved it from the Protestants. The merit of every religious doctrine needs to be examined, especially the doctrine that ultimately gained widespread support. Second, continuity in religious thought is just as important to examine as the divisions. This study will argue that the commonality of the Christian experience was enough to bridge doctrinal gaps during the sixteenth and seventeenth centuries. Collinson (2002) reminds us that pre-Reformation England inhabited the same moral universe as the postReformation, with belief in divine providence and sacrality still playing a central role in people's lives.

\section{Pluralist Protestantism}

The denotation of the word 'Protestant' is a nebulous pursuit in the context of the English Reformation, as the rise of an alternative expression of Christianity unfolded under different circumstances in England that it had across continental Europe. With the exception of several pockets of allegiance to the traditional religion, such as the north or in areas that subscribed to a seigneurial Catholicism (Gregory, 1998, p. 309), it is beyond dispute that the sixteenth century concluded with most of the populace vehemently opposed to Catholicism. This prevailing enmity appears to have been directed towards the institutional manifestation of the Church, especially the papacy, rather than merely along strict theological lines. The emerging sense of nationalism was intimately tied into this international bias against a 'foreign' religion based on the Italian peninsula and followed by all of England's enemies. Haigh (1993, p. 290) summarizes the people of this period as thoroughly stripped of the Catholic social and cultural identity, but still no closer to a Protestant one. 
The seventeenth century emerged in the successful wake of the Tudor initiatives to dismantle the Catholic religious apparatus in England. The godly 'true believers' of the theological underpinnings of the Reformation were left with two consequences of laissez-faire conformity promoted by both Elizabeth and James. First, the Church of England failed to foster a true Protestant expression of faith within the parishes; this left them susceptible to the infusion of 'high church' innovations promoted by Laud. Second, the sixteenth-century war on Catholicism and the seventeenth-century Civil Wars had weakened the entire cultural identity of religion, resulting in sharp deterioration of piety evidenced by diminishing church attendance (Whiting, 2010, p. 268).

In developing a methodology to ascertain to what extent Protestantism, on any theological level, took hold in England, church fittings are one of the most critical sources for evidence. The modifications made to church interiors, especially to iconographic motifs, at various stages provide valuable insight that suggests the Protestant doctrine of sola scriptura was embraced by parish leaders, which soon trickled down visually to the congregations. If any attempts to educate the laity in Protestant doctrine, through itinerant preaching or promotion of literacy, failed, the material record suggests that key fundamentals did take root in this unintentionally passive way. As the divide between godly Puritans and hierarchical Anglicans grew, the vast majority of Englishmen and women existed in a transient state of being simultaneous influenced by the Bible, either visually or textually, and a secular-driven indifference for religion in general. This manifests itself in this studies data through high rates of survival of church fittings and images inspired by Scripture combined new furnishings featuring an increase in the use of heraldry and secular exaltation.

The notion that the Reformation in England, and beyond, was a failure is a conclusion that can be drawn from the documentary evidence. After decades of unrelenting attacks on the Catholic faith and marriages of convenience with secular authorities, Protestants had inadvertently done irreparable damage to the greater cause of religion. While wills can provide some glimpses into the inward intentions of a parishioner, other documentary records compiled by churchwardens, governments officials or the clergy do not provide any sense of how educated the laity was in the tenets of the new faith. 
The religious extremists who did comprehend and embrace Protestantism must have bemoaned the theological ignorance that continued in England, in spite of any attempts to the contrary of the pulpit. It should come as no surprise that the generations that followed the sixteenth-century break with Rome had trouble adjusting to the new order of the day. For medieval Catholics, it was not the place of the laity to 'understand' but to 'do', preferably without question. It was this paradigm that created an environment of indifference should the 'works' component of religion be diminished in favor of a faith-based model which required an intimate and personal understanding of religion to establish a priesthood of all believers. In spite of these difficulties, progress was being made, although certainly not at rate yearned for by the 'godly.'

The initial divide in English Protestantism foreshadowed the religious component of the hostilities which would erupt in the seventeenth century during the Civil Wars. First, the 'authorized' form of religion operating in the parish churches, guided by the Book of Common Prayer and led by the English monarch. Second, the 'common' form which was extraordinary fissiparous, ranging from Lutherans and Calvinists to those who evolved those who believe in superstition and magic while still operating within the Catholic Church. While the former did its best to promote a worthy orthodoxy, the latter proved appealing enough to prevent the homogenization of English Christianity.

If we take a myopic view that the Reformation was strictly about the abolition of medieval Catholicism, then the reign of Henry VIII succeeded in obliterating all formal ties and most religious elements outside of the parish churches. The creation of a truly Protestant nation would require a new professional role to be undertaken by the clergy. If the laity were to read, or at least hear, scripture and have a personal understanding of their religion, then the new clergy would need to be both educated and supportive of the national agenda now baked into the uniquely English Protestant identity. This new message could be spread orally, through the sermon; textually, through reading the Bible or other devotional literature; and even visually, through the surviving or new decorative motifs still found strewn about church interiors. England had a special affinity for the printed word, as circumstances had led to a vernacular edition of the Bible circulating before the Reformation. 
Where this promotion of literacy created a barrier to access, iconography still remained a great equalizer in terms spreading the Protestant message of sola scriptura. Church attendance also provided access to sermons and Anglican liturgy, but the material fabric of the buildings themselves cannot be discounted as a strong influence on the 'common' perception of religion. The duality of literate/illiterate and print/oral suggests a line of demarcation which is an oversimplification of Protestantism, which was at its core a religion of the Word (Gregory, 1998, p. 319). If the average parishioner could not grasp the theological dispute viewing Mary as the Mediatrix of All Graces, they would still receive a strong message from the defacement or removal of Virgin iconography.

By the seventeenth century, dissenters who refused to conform to the orthodox Anglicanism began to assess both the various expressions of Protestantism within an English context and what the Reformation actually meant. Cultural reflections like this may have contributed to the successive spikes in religious activity, ranging from Puritanism as one expression with the evolution of Arminianism towards Laudianism as another. The impetus for such reflections may also be linked to a generational revolt, a seemingly inevitable result of allowing a variety of thought into a societal equation. Disaffected intellectuals of each generation following Henry VIII's break with Rome would seek to discover their own path to God This challenged the need for a permanent fitting designed to partition this space, which can be observed and continue the unfolding process of defining what it truly meant to be an English Christian.

These groups would often find themselves simultaneous at odds and intimately entwined with the Church of England, as the only mechanism really capable of disseminating the message of religious truth to masses. The evangelizing aims of all of these groups followed a similar path, as many of the tactics employed were pioneered by Catholics during their Counter-Reformation and earlier. For all of their differences, all Christians were bound to the Great Commission to the spread the true teachings, depending on your interpretation of such, to the world (Matthew 28.18-20). 


\section{Top Down \& Middle Out}

Unlike other movements in Europe, the circumstances surrounding the Protestant Reformation in England were quite exclusive, as the most sweeping elements were instigated by the central government and trickled down through the rest of the country. In Norfolk, this created a synergy with an increasingly affluent and educated middle class, who were exposed to Protestant thought via commerce with the continent. Combined with those who benefited economically from the seizure of Catholic wealth, including the city corporation at Norwich, this 'middle out' propagation provided change at a more local and granular level in conjunction with official policy.

As we have observed, an assessment of the success or failure of Reformation hinges on the definition of 'Protestantism'; as the series of legislation passed between 1532 and 1534 engineered religious reform from the highest echelons of secular authority. While it could be argued that this effectively rendered England a 'Protestant' nation, the earliest doctrinal declarations, such as the 1539 Six Articles, reaffirmed most Roman Catholic practices. Those who desired a true theological Reformation were disappointed to find that little had changed beyond the transference of papal authority and sovereignty on religious matters to the monarchy. The subsequent reign of Edward VI presented an opportunity to surge forward with the forceful promotion of Protestant orthodoxy, defined by the assault on the material fabric of parish churches and the subtle, yet paramount, doctrinal changes made by Thomas Cranmer in the Book of Common Prayer. In Norfolk, the success of the Reformation relied upon a 'middle out' support for religious reform. As we have discussed, the seizure of Church wealth provided countless opportunities for 'new men' to gain influence and land, as seen at Edingthorpe. Furthermore, the ensuing chaotic transitions always offered a chance to climb the social ladder, as seen at Dickleburgh following the fall of Thomas Howard, fourth duke of Norfolk in 1572 .

In terms of middling secular authority, the city corporation of Norwich recognized the opportunity to increase its prestige through the provision of social welfare programs which had previously been provided by monastic orders. As early as 1538, Augustine Steward, mayor of Norwich, contacted the Lord Privy Seal Thomas Cromwell for his 
assistance in acquiring the Blackfriars Hall, which had recently surrendered to Henry VIII. By 1540, the transaction was complete, and the city took possession of the building for the sum of $£ 81$ (Houlbrooke $\&$ McClendon, 2006, p. 261).

The church of St Helen and the Great Hospital, established in 1249 by the episcopacy, provided healthcare to the massive clerical population which served the city's numerous parishes and orders. Following its dissolution by Henry VIII, the corporation recognized an opportunity to extend a service to the entire city and develop a system of institutional relief for the poor (Houlbrooke \& McClendon, 2006, p. 261). This political evolution was made possible through new acquisitions and a void in social welfare created by the abolition of the monasteries. The transference of a social justice mandate from the Church to the state is a testament to the iconoclasm of belief and attitudes.

\section{Stability Over Conformity}

Many tropes of a modern society, such as toleration and nationalism, were driven by the Reformation, especially the sixteenth-century efforts to de-Catholicize the country. Muriel McClendon's (1999) outstanding study chronicling the de facto religious toleration demonstrated by the Norwich magistrates suggest that civic stability was valued over theological convictions and even loyalty to the central government. In the wake of the Henrician assault on the Church, cases of heresy shifted from ecclesiastical courts to the mayor's bench; a transition unto itself that would only naturally transform the emphasis from religious to civic. Nearly every case involving dissent, ranging from denouncing the Supremacy and Cromwell to openly condemning the Six Articles, were met with swift leniency. This approach to dealing with religious turmoil from both sides of the dispute served dual purposes. First, a tolerant approach created a positive rapport between the citizens and their local government, as no one group would feel disenfranchised or persecuted. Furthermore, even the more enthusiastic reformers, many of whom wished for a sterner enforcement of the law, had to appreciate that even-handed approach of the magistrates should the legal pendulum ever swing against them, something which happened many times just during Henry's reign. Second, the relative stability achieved during a potentially tumultuous period helped Norwich retain a degree of autonomy to operate without any additional royal or aristocratic 
interference. For instance, before the dissolution of Norwich Blackfriars, their prior had openly vilified the Royal Supremacy, an act which caught the attention of Thomas Cromwell. Cromwell employed one of his aristocratic agents, Sir Roger Townsend, to act on his behalf and arrest the prior for treason. Not wanting any meddling from a royal official or local rural family, the mayor of Norwich, Augustine Stewards, was able to broker an arrangement where the prior would remain unmolested in the city and remain available should any further action be needed. This clever maneuver took advantage of a bureaucratic crack, as Cromwell never followed up and the prior lived out his days until his death in 1563 (McClendon, 1999, p. 93).

As previously discussed, this de facto toleration helped empower the city corporation as it created a stable environment which relied more and more on the local magistrates to provide a plethora of services previously offered by the Church (Tittler, 1998). This transference of reverence elevated the prestige of the Norwich municipal authorities, as the citizens came to rely on their programs while the parish churches continued to look to them as a charitable benefactor.

\section{The Long Reformation}

The English Reformation had been recast as a series of events, which both lasted longer and began earlier than previously assumed. Evangelical activity had already taken root by the 1520 s and was bolstered by the political and theological reforms being instigated by the central government the following decade (Tyacke, 1998, p. 6). This alteration to chronological boundaries of Reformation also meant that the lines between the Tudors religious policies and the Stuart conflicts of the following century were more blurred, as one bled directly into the next (Marshall, 2009, p. 568). This study concurs with the 'long' approach to the Reformation, as it extends well into the $17^{\text {th }}$ century, past the Civil Wars and concludes with the restoration of the monarchy in 1660.

A chronological analysis is essential in determining both why and how the Reformation happened. One prevailing model championed by Haigh is that it took place at varying speed from above and below, as injunctions being pushed from the central government converged with a grassroots Protestant minority. This study, which has looked at both rural and urban churches in Norfolk, attempts to offer a more granular model. In 
addition to comparing the dichotomy between country and town, the social order and hierarchy of power of these areas provide an additional layer in determining why the Reformation was successful across the county. The revisionist model of Haigh has successfully shifted the earlier timetable put forth by Dickens and Elton; with England being cast as a thoroughly Protestant nation by the conclusion of Edward's reign (Haigh, 1993).

The question of 'when' the Reformation took place also needs to consider the definition of the term 'Protestant.' By this, do we mean a godly nation fully in tune with the theological implications put forth by Calvin and Luther? It is difficult to imagine that a mere generation following the widespread embrace of a works-based faith, complete with the ceremonial rituals being conducted in an alien tongue, that most people were ready to embrace a new religion that required a personal commitment fueled by both individuality and literacy. What we may be able to say of the Elizabethan Church is that while there was an uncertainty of both meaning and intention of religious life, the surviving church fitting and decorations suggests that the nation was no longer Catholic. This new paradigm appears to have been divided into two broad categories; one active and one passive. The first category, or the active model, sees a fairly rapid progression from non-Catholic to anti-Catholic; although, by anti-papist would be the more accurate label. This area could also extend to include those pushing a theological Protestantism, which was a far smaller minority throughout the sixteenth century. The second category, or the passive model, refers to the throngs of Englishmen and women who continued to conduct most elements of their religious lives with similar intentions as they had when the ecclesiastic hierarchy stretched all the way to Rome. Even if a traditional sense of sacrality and regimentality fueled their religious life, the theological underpinnings had dramatically shifted. This study has suggested that use, or preservation, of certain visuals within parish church interiors helped bridge this chasm and allowed the transition to unfold in a far subtler fashion.

While any assessment of the Reformation will naturally utilize the 1534 Supremacy as its fixed point of origin, the religious status quo in England had already been challenged; as evidenced by the Lollard movement and general trends in iconographic depictions during the fifteenth and early sixteenth centuries. Reformers needed to 
bolster their position by grafting their narrative into a broader historical context, leaving the Lollards as the most prominent candidates. This resulted in not only a bias interpretation of Wycliffe's teachings, but a 'celebratory' assessment of the Reformation which suggested an inevitably Protestant destiny (Aston, 1984) (Walsham, 2010, p. 143).

The collective memory of Lollardly utilized by the reformers is important to address, even if connection was artificially manufactured during the Reformation. Wycliffe provided an early critique of monasticism, the papacy, the elevated status of the clergy, the veneration of saints and the sacraments themselves. His championing for a vernacular translation of the Bible provided a theological foundation for his followers, the Lollards, and indirectly for the Reformation itself. By 1428, this heretical movement had reached Norfolk through the efforts of itinerating preachers who relied on the charity and protection of local residents throughout the county and boasted a modest population. The first of these preachers, William Sawtry, also became the first to be executed following an ecclesiastic investigation and trial. A royal proclamation against heretical teachings in Norwich and Norfolk, issued in 1408, demonstrates the severity of the situation; which culminated in the Oldcastle Revolt, an uprising directed against the Church and king which transpired at London in 1414. Despite the fact that John Oldcastle, the architect of the rebellion, owned land at Burnham Westgate, not a single Norfolk man participated in the insurrection. Sparse Lollard activity continued to be recorded around Norwich and throughout the $R-N E$ sample, including at South Creak and King's Lynn (Jurkowski, 2007).

Thomas Cranmer proclaimed that Wycliffe was correct to place scripture at the center of his religious worldview, while John Hooper recounted his early resistance to the 'popish' mass. In his own critique of the monastic system, John Bale agreed with his denunciation of friaries. Even Henry VIII was intrigued by the connection between Wycliffe and his own policies, as he requested a copy of the articles of condemnation from Oxford in 1530 (Pollard, 1906, p. 91). Despite the lack of broad adaptation, reformers argued that the movement sparked by Wycliffe did anticipate the Reformation by nearly two centuries; simultaneously defined as the evening star of medieval scholasticism and the morning star of the English Reformation (Michael, 
2003, p. 343). Instead, it appears that the most lasting contribution to the Reformation made by Wycliffe was his translation of the Bible, which shaped generations of Christians who were able to read in English and finally access Scripture for themselves.

As discussed earlier, the limited impact these movements had on England make it difficult to draw a direct correlation with the Reformation itself; however, the central Lollard theology did correspond with the forms of Protestantism embraced by many reformers during the sixteenth and seventeenth century. Furthermore, a general observation made throughout the case studies reveals an overall trend towards Biblical iconography for fittings commission in the late fifteenth and early sixteenth century; demonstrating an emerging bias for Scripture.

While this study marks the end of the extended Reformation with the ascension of Charles II in 1660, the poor and uneven spread of Protestantism makes it difficult establish a conclusive end date. If Protestantism is defined merely as a form of Christianity outside of the orthodoxy of Roman Catholicism, then it would be far simpler to establish the Henrician break with Rome, the Edwardian innovations, Marian turbulence, and subsequent Elizabethan Settlement as watershed moments which assured a return to the Church was unlikely, even if the country still thought and experienced their faith within a Catholic context. The division in religion soon shifted to what it meant to be a Protestant, as a godly reformer who sought to strip the altars bare or an Anglican who desired to restore the liturgical glory of the medieval church within a distinctly English fashion. This fragmentation was exaggerated by the excesses of the Civil War, as increasingly radical forms of Christianity appeared to convolute the Protestant landscape further. The failure to uniformly Protestantize the nation resulted in not only nonconformity but even the fear of a subversive Catholic coup of James II under the guise of religious liberty and toleration in the late 1680s.

While church fittings beyond 1660 do not play a significant role in this study, a cursory examination cannot be avoided as they often exist amongst, or even within, medieval and early modern cases. The intriguing irony is that the hybrid Protestantism of the Anglican church, which had done so much to undermine the old Church, soon needed to reaffirm the importance of religion and restore its centrality in society. While 
toleration for other modes of worship did eventually come, first to nonconformists in 1689 and then at a more sluggish rate during the eighteenth and nineteenth century to Catholics, a new campaign to restore flagging church attendance through the restoration of the church buildings themselves. It was believed by the Church of England that if the physical trappings of religion could look Gothic, it would restore antiquated attitudes towards religion. These Victorian restorations paradoxically saw the ruin of a great deal of both the surviving medieval and post-Reformation fittings; an unfortunate result of this attempt to re-Christianize the nation. This continuing, and dramatic evolution of religion in England suggest the notion of 'reformation' was simultaneously a success and a failure within the time periods covered in the study; the success being an undisputed break with Rome, along with an improbable return, and the failure being new church's inability to forge true uniformity, culminating in the eventual need for a campaign to reverse the secularism unwittingly seeded at the Reformation.

Work done on the Reformation under Elizabeth has shown that an increase in literacy and successful change in culture mitigated the threat of local insurrection in response to the new religious orthodoxies. As a result, a local, and diverse, sense of piety sprung up and began shaping the identity of the English counties. As religious impositions came down from the central governments, the parishes often went along with what was asked of them in their unique way. This contributed to a Church which was conformed and quiet, but without a clear uniformity (MacCulloch, 1986).

It has been observed that this disjointed approach to Protestant reform was a result of a general lack of capacity in England for abstract religious innovation. Instead, they merely tried to coop the teachings of Luther and Calvin without a clear understanding of which theology would best suit the kingdom (MacCulloch, 1990, p. 55). The consequences of this were first realized during the reign of Elizabeth, as the prospects of a popular Catholic restoration became less likely. Following the 1559 settlements, the Church of England was in a state of arrested development in regards to any additions Protestant reforms, although a growing portion of the clergy and laity would have liked to see things taken further (MacCulloch, 1990, p. 142). 
As the identity of the Church of England was never clearly defined beyond its break with Rome, the seventeenth century saw a shift in religious tension towards shaping Anglican orthodoxy. Laudians had a more inclusive approach to other Christian faiths, including Catholics, and spurned the notion that the Church of England was the only true church (Milton, 1995, pp. 8-10). In spite of this challenge to the earlier emphasis on church uniformity, these positions never gained widespread support in the parish churches as the accusations leveled against Laud and his followers of being too sympathetic to the Catholic cause were quite unpopular (Walsham, 1998, p. 650). Meanwhile, the Puritans were a committed and influential minority, who secured key positions in order to promote their positions whether or not they had a popular consensus (Capp, 2012, pp. 4-6). They believed that the Reformation had only just begun, as the fear of a Catholic resurgence was ever present and provoked excessive measures in ensuring that would never occur.

\section{Sacrality}

It has been observed that the Reformation stripped Christianity of key elements of its sacrality, as miracles and magic were supplanted by a more introspective faith in God, which drove England towards a secular and rational modernity (Thomas, 1971). This assessment has been challenged as the notion of sacrality survived, as the emerging incarnation of Protestantism sought to accommodate the traditional sacramental needs of parishioners while continuing to promote the centrality of the Word. The result was not the elimination of sacrality; instead, it was a transition from saints, relics, and feasts to church fittings which facilitated both the Word and administering of the remaining sacraments (Scribner, 1993, p. 476 - 483).

More recent work has affirmed this perspective, as the sacramental bread, prepared by human hands, was superseded by the Word of God, which not a temporal creation. This provided a greater sensory experience, which allowed parishioners with direct access to the divine without the plethora of visual distractions which had previously adorned church interiors (Milner, 2011, p. 348). Furthermore, the concept of supernatural miracles was actually bolstered during the period as natural disasters become increasingly seen as acts of divine judgment levied again the sinful (Walsham, 2008, pp. 506-508). 


\section{Death}

The notion of death itself was transformed during the Reformation, as the blurred lines between life and the afterlife had become increasingly binary, with a soul becoming beyond reach with heaven and hell being the only destinations. The superstitious belief in visitation from the dead was explained away as either a product of imagination, a deception of Satan, or even worse, the papacy (Marshall, 2002, pp. 196-197).

The abolition of the concept of purgatory sparked a tremendous debate within the Church of England and its parishioners in regards to what occurred between death and the resurrection found within Christian eschatology (Thomas, 2009, p. 227). Yet, it appears that the Reformation succeeded in the transforming the purpose of a funeral from aiding the soul of the deceased to now providing comfort for the affected living (Houlbrooke, 1998).

\section{Physical World}

An analysis of parish church interiors during the Reformation have revealed that the debate surrounding altars was the crux of many theological conflicts, initially between Catholics and Protestants, but later amongst various sects of Anglicans (Fincham \& Tyacke, 2007). These warring factions both had competing views of Protestantism, one being internal and attracted to reason and faith, while the other was external and theoretical (Milner, 2011, p. 350).

In spite of any legislation, the changes made to parish church interiors through much of the Reformation were ultimately financed and conducted with care at a local level with the intent of facilitating the new modes of worships being instituted (Whiting, 2010). The more indiscriminate and destructive excesses were carried out later during the Civil Wars by outside commissioners who imposed their will in these parishes after nearly a century of independence (Fincham \& Tyacke, 2007, p. 53).

\section{Material Fabric}

The religious identity of England before the Reformation was intimately tied to the material fabric of the parish churches, as church fittings provided physical touchstones which were integral to the common perception and experience of faith. As previously 
alluded to, the 'erosion of the sacred' or 'relocation of holiness' undermined the superstitious association of divine power imbued within temporal objects (Aston, 2003, p. 22). God was not something to be harnessed through a ritual or relic; instead, personal introspection informed through the hearing and reading of the 'Word,' forged a direct connection.

This transition even stripped the clergy of their sanctified position, as their importance now hinged upon the fluctuating prestige of the Anglican hierarchy and local respect from parishioners for the central role of proclaiming scripture. Furthermore, the remaining sacraments, and fittings required to administer them were purged of much of their sacrality as they were transformed into an outward sign of faith as opposed to a divine pathway to God's grace.

This democratization of Christianity enabled a common parishioner to experience their faith in a more intimate way, as all now had equal access to their faith. The surviving material fabric of the parish churches throughout Norfolk confirms Aston's assessment, as reformers purged offensive objects and mutilated images found on fittings previously associated with holy sacrament, without any fear of divine retribution. From the Protestant perspective, holiness had shifted from an object or position in a building to an inner light burning in all people; a fire to be stoked through constant ingestion of the Word of God.

The significance of Lollard iconography has been examined in regards to how it initially developed and later how the Reformation incorporated various approaches. Iconoclasm posed a unique problem, as visual learning could be far more effective in teaching Scripture to parishioners than relying on the widespread circulation, and understanding, of vernacular editions of the Bible (Aston, 1984). It was later demonstrated that the extremism of a small sect Lollards, who saw all images as 'graven' in accordance with the Ten Commandments, shaped the practical iconoclasm of English Protestantism. Yet, with the exception of the Edwardian regime, it appears that Reformation legislation was purposefully crafted to avoid the unrestrained destruction of all images (Aston, 1988, pp. 337-341). The selective iconoclastic activities continued to transform from spontaneous public actions to officially 
sanctioned acts instigated by the central governments and trickled down into the parishes (Aston, 1993). This resulted in a far more orderly assault on images, which instead of being carried out by an irrational mob, was conducted by carpenters and masons formally commissioned by the churchwardens. This suggests not only the absence of Protestant fervor seen in other areas across Europe, but also a strong sense of local identity and parish pride which did not want to see their churches ransacked (Aston, 1988, p. 16).

It has been observed that fanatical iconoclasm could potentially create an environment without any representations, thus fostering a faith based solely on both custom and memory (Koerner, 2002, p. 213). Additional work on iconoclasm examined the extent to which church interiors were altered to accommodate reformed worship, as the emphasis on a text-based faith over the traditional Mass is evident from the changes made to the east end of these buildings. Such transformations of public worship were also attained through acts of iconoclasm, as defaced images and new secular emblems served as an enduring reminder to parishioners of the new order (Aston). This resulted in the concept of holiness being confined only to the remaining sacraments and Scripture, with the church itself stripped of sacrality, in spite of Laud's attempt to reinstitute it (Aston, 2003, p. 24).

\subsection{Archaeology}

The influence that the Reformation had on the everyday lives of the average parishioners emerged as a question which archaeology could make significant contributions to. The prevailing attitude in regards to the impact this period made on the material record was mostly myopic, as it was thought that the evidence of destruction was best that could be extrapolated. This proved to be inaccurate, as archeology was utilized in new ways to investigate religious belief and practice in England in the periods before and during the Reformation. At a 2001 conference held on the issue, it was demonstrated that assessing either the triumph or failure of Protestantism did adequately addresses the complexity of the period. Instead, the material records suggested a hybrid approach prevailed, as elements from a Catholic past was integrated into a world which was technically Protestant (Gaimster \& 
Gilchrist, 2003, p. 3). At this conference, the work done in the area of both public worship and iconoclasm is quite relevant to this particular study, as parish church fittings were intimately tied to prevailing religious beliefs, attitudes and rituals.

\section{Public Worship/Iconoclasm}

The Protestant Reformation required that existing public spaces of worship needed to be converted to accommodate new liturgy and preaching. As most of these buildings were designs to facilitate the medieval Catholic Mass, some degree of continuity was inevitable as they were transformed into houses of reformed worship through use of both iconoclasm and gradual adaptation. This has been examined as the interior of converted parish churches in the Netherlands retained far more material culture from their Catholic past, such as organs and stained glass, than comparable reformed spaces found in Scotland (Spicer, 2003).

The sample groups selected for this study are designed to explore the impact that the Reformation had different rural and urban regions within a local context confined to a single county. Similar methodical approaches have already suggested that the rate of surviving church fittings varies across different geographic areas. These findings imply that the actions of local individuals, ranging from zealous reformers to powerful families, were just as responsible for the alterations to church interiors as any national ordinances being enforced by royal commissioners (Oakey, 2003).

\section{Private Devotion/Material Culture}

The material culture of devotion, one of the primary elements of this work, was shown to be pivotal in gauging both acceptance and resistance to new religious orthodoxy being imposed on the parishes. It has been demonstrated that the continued use, transformation or concealment of Catholic artifacts allowed for parishioners to continue to experience their faith within a traditional context, in spite of this being at odds with the new Reformation theology (Tarlow, 2003). This interpretation is central to the approach this study will take in its assessment of church fittings, as this argument is key to understanding the ultimate success of England's break with the Church. 
Other works conducted on domestic artifacts during the period have demonstrated the swift impact the Reformation had on home devotion, as the flow of influence from the public sphere into the private reflect a gradual shift in emphasis from temporal to secular. The removal and censoring of church icons, combined with the explosion of print material available in the $16^{\text {th }}$ century, saw the inspiration for domestic materials, such as stove tiles or statuaries, shift from exclusively religious to "polemical and politically sectarian" (Gaimster, 2003, p. 137).

\section{Dissolution/Secular Power/Corporate Charities}

Although outside of the direct scope of this study, archaeology has already made immense contributions to considerations regarding the Dissolution of the monasteries and chantries under the Tudors. As the lands the monastic lands were seized and sold off, the buildings themselves suffered various fates, such as conversion for private use or slowly dismantled to serve a stone quarry and builders' depot (Howard, 2003) (Morris, 2003). The pace of the physical destruction of these buildings has also been revealed, as it has been argued that the process was often sluggish and was far more contingent on economic factors rather than theological (Soden, 2003).

Beyond parish churches and monasteries, the analysis of other buildings, such as guildhalls and abolished chantries, demonstrate that the traditional paradigm of corporate charity shattered. Trading companies and local authorities assumed control of many of these establishments, as the religious fraternities who built them were dissolved. While the continuance of these building was another case of proving communities with a sense continuity, the emphasis of the charity being provided shifted dramatically from the souls of the dead to the welfare of the living. This transition did fill an important social void left by the Dissolution but laid the foundation for a new system which defined, displayed, and disciplined the marginalized elements of society, such as the poor (Giles, 2003).

This transition from religious to secular was also demonstrated through archaeological assessments on parish church chantries. As these practices became outlawed, the social implications associated with them remained as the status achieved by having a thousand masses said for your soul could still be gained through the construction of an 
immense funerary monument. This idea has been examined, as space was purposefully appropriated with areas previously reserved for their liturgical significance now used as static stages for the wealthy and powerful to flaunt their dominion in a communitybased setting (Roffey, 2003).

\section{Commemoration}

The archaeology of commemoration provides context to practices which retained both social and cultural significance during the Reformation. Work conducted at churchyards and monastic cemeteries suggest that the perpetuation of the memory of the dead endured, as medieval burials located suppressed monasteries were relocated to parish churches. This strong connection to the past coincided with the introduction of new practices, such as the increased use of coffins and no longer segregating the burials of adult and child (Gilchrist, 2003). Additional work done on parish church monuments demonstrated a sharp decline in their intercessory function, as the focus shifted more on the remembrance of the lives of the departed rather than their immortal soul (Finch, 2003). Finally, the treatment of funerary fittings located in parish churches during the Reformation suggest the essential role of both memory and authority, as the endurance of both monuments and brasses became less contingent on the notion that the memory of the dead provided some degree of protection and more on generational legacy of the local authority (Hutchinson, 2003; Finch, 2000). 


\section{Chapter IV: Survivals}

This chapter will present a detailed analysis of medieval church fittings, predating the 1534 Acts of Supremacy, which survived defacement or destruction during the following 126 years of religious transition, transformation, and upheaval defined as the 'Reformation' in this study. Unless a fitting is directly referenced in the written record, it becomes a difficult task to determine the exact nature and circumstances of its survival; however, the finite conditions possible to contribute to their endurance are examined and discussed. The evidence suggests a broader interpretation of the religious imperative of early reformers, and later of Anglicans and Puritans.

\subsection{Baptismal Fonts}

\section{Introduction}

Aspersion or affusion baptismal fonts are one of the most enduring religious artifacts from the medieval church. In medieval England, these fittings were intended to administer the sacrament of baptism through aspersion, or sprinkling, and affusion, or pouring, as opposed to an immersion method. This sacrament was one of the seven sacred rites administered by the Roman Catholic Church as an 'efficacious signs of grace, instituted by Christ and entrusted to the Church' that were a fundamental component of religious life throughout England until the outset of the Reformation (Catholic Church, 2000). In medieval England, fonts were often constructed of stone, such as highly polished Purbeck Marble, and were comprised of an octagonal basin placed atop a low pedestal about 1.5 meters high (Bond, 1908, p. 252).

The use of stone in the construction of fonts was a result of the need for the perpetual conservation of the blessed water; stone fonts needed to be impermeable, or lined with a metal interior. This need to protect the fluid from contamination led to the creation of additional fittings to ensure the safety and cleanliness, including cloth-lined covers and wooden canopies. These practical safeguards were elaborately adorned themselves, with the dome-shaped covers and four post canopies containing rich and detailed 
carvings. They helped ensure the sacred water of the font had its hygienic integrity safeguarded.

In addition, fonts needed to be protected from congregants who increasingly believed in its the supernatural power; this belief was addressed through ecclesiastical legislation across Northern Europe during the thirteenth century (Herbermann, 1907, p. 275). In England, Bishop Richard Poore, during his episcopacy at Salisbury, issued a series of statues to combat these beliefs, as did a number of continental councils (Moorman, 1945, pp. 236-238).

The Sacraments of the Catholic Church were a common decorative motif on octagonal stone fonts. In these cases, a relief sculpture or painting of each sacrament adorned each side of the bowl, with a free panel to spare. While many of these 'idolatrous' visual representations of an abolished theology fell victim to iconoclasm, the necessity of the fitting did not change. As part of England's via media, or 'middle way', compromises during the composition of the Thirty-Nine Articles (1563), baptism became one of the two sacraments "ordained of Christ our Lord in the Gospel." (Bray, 1994, p. 508). This intimate connection between the material record and the sola scriptura doctrine relied heavily on all references to water baptism found throughout the Bible.

The survival rates of medieval baptismal fonts across the four sample groups is a staggering testament to the enduring nature of this particular sacrament in the face of successive waves of religious reform and upheaval. From the commencement of the Tudor break with Rome, the importance of infant baptism was evident in its inclusion in the earliest doctrines laid out for the new English church. In 1536, Henry VIII sanctioned the Articles devised by the king's highness, to stable Christian quietness and unity among the people, to serve an initial set of doctrinal guidelines for his new church. The traditional positions presented served less a platform to integrate reform theology and more to define the autonomy of Christianity in England. The matter of baptism was addressed as the second of the principal articles of faith and was still referred to as a "holy sacrament" (Bray, 1994, pp. 162-174). It is important to note that even the more radical incarnations of reform, influenced by continental Calvinism, still 
required baptism, and communion, as a sign of the new covenant between God and man.

The survival rate of baptismal fonts across the four samples is significantly higher than any other fitting with roughly six survivals out of every ten churches; the remaining churches are either without a font or possess one constructed after 1534. The exact nature and condition of these stone artifacts vary, with some survivals classified as defaced, while others are a product of innovation. As previously outlined, the medieval fonts which escaped any physical destruction will be discussed here, with the damaged survivals being covered in the next chapter. Despite the high survival rate, there remains an interesting disparity in survival rates across the four sample groups. First, the difference between the rural and urban samples is a wide margin with a rate of .68 fonts per church and .45 respectively. Figure 7 demonstrates that the majority of these survivals across all four samples are fonts constructed during the two centuries preceding the beginning of the Reformation with a sharp fall off until later in the Stuart reign. Regardless of the more remote nature of the rural parishes, this gap is worth noting and exploring. Second, the rural samples contain smaller variances with $R-N W$ with a rate of .62 fonts per church, $R-N E$ with .71 and $R-S$ with .72 . These impressive rates were unexpected, as a Parliamentary Ordinance of 1644 commanded that no stone fonts " shall be, or be any more used in any Church or Chappel within this Realm" (Firth \& Rait, n.d.).

Iconographic depictions carved into the exterior of the font bowls and stems, and spared of any agency of iconoclasm, tend to have a direct or indirect relation to a figure or concept derived from scripture. While many images produced by Catholicism in England can claim such a connection, many saints and rituals gained prominence through fifteen hundred years of tradition accumulated by Christianity since the closing of the Biblical canon. It is content of this nature that an increasingly literate populace discovered to exist outside the primary literature, and thus potentially characterized as superfluous, and even offensive. This same population would have also encountered over a dozen references in the New Testament that espoused the necessity of baptism as either a sign of unity (1 Corinthians 12:13) or a direct means of salvation (John 3:5, 
Acts 2:38). Baptism survived the Reformation and remained the gateway to salvation, in spite of shifts in theological significance.

Fonts in Norfolk to survive unscathed predominately feature imagery with direct biblical inspiration, such as Christ, the Instruments of the Passion and the Apostles, indirect inspiration, such as quatrefoils, angels, and lions, or secular inspiration, such as the Tudor rose or even the Labors of the Months. In the following chapter, we will assess fonts produced in the same period, but feature defaced images, such as sacramental scenes or extra-biblical saints, before moving onto the new criteria for font iconography created after the start of the Reformation. 


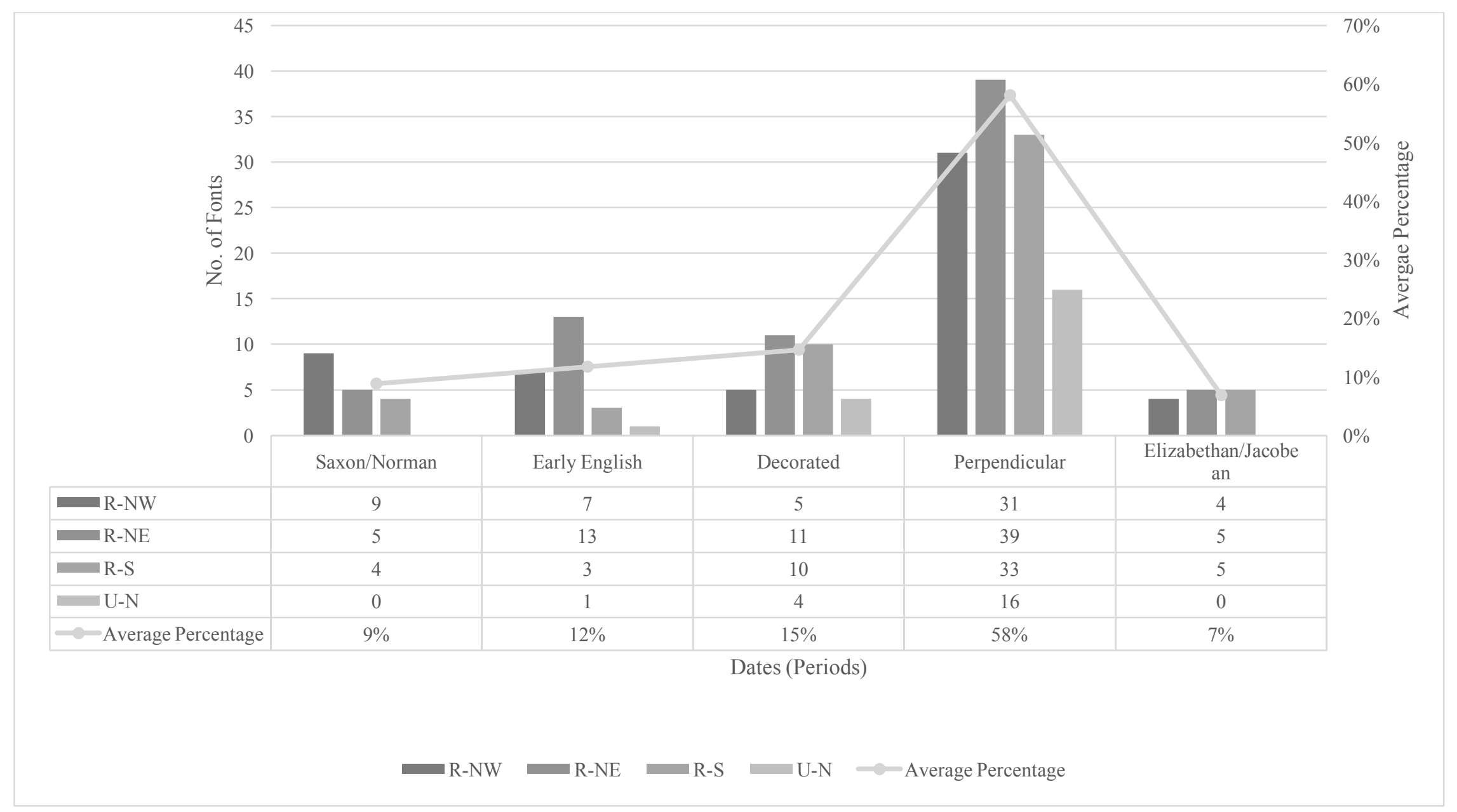

Figure 2: Baptismal Fonts: Chronological Distribution 


\begin{tabular}{|c|c|c|c|c|c|}
\hline Sample & & Church & Font & Percentage & Per Church \\
\hline & & (c) & $(f)$ & $(\% f)$ & $(f / c)$ \\
\hline \multirow[t]{6}{*}{ R-NW } & Brothercross & 10 & 7 & $13 \%$ & 0.70 \\
\hline & Freebridge-Lynn & 36 & 23 & $41 \%$ & 0.64 \\
\hline & North Greenhoe & 21 & 11 & $20 \%$ & 0.52 \\
\hline & Smithdon & 20 & 12 & $21 \%$ & 0.60 \\
\hline & King's Lynn & 3 & 3 & $5 \%$ & 1.00 \\
\hline & TOTAL & 90 & 56 & $100 \%$ & 0.62 \\
\hline \multirow[t]{5}{*}{ R-NE } & Blofield & 19 & 13 & $18 \%$ & 0.68 \\
\hline & South Erpingham & 39 & 28 & $38 \%$ & 0.72 \\
\hline & Taverham & 19 & 12 & $16 \%$ & 0.63 \\
\hline & Tunstead & 26 & 20 & $27 \%$ & 0.77 \\
\hline & TOTAL & 103 & 73 & $100 \%$ & 0.71 \\
\hline \multirow[t]{5}{*}{$\mathbf{R}-\mathbf{S}$} & Depwade & 23 & 19 & $35 \%$ & 0.83 \\
\hline & Diss & 16 & 12 & $22 \%$ & 0.75 \\
\hline & Guiltcross & 14 & 8 & $15 \%$ & 0.57 \\
\hline & Shropham & 23 & 16 & $29 \%$ & 0.70 \\
\hline & TOTAL & 76 & 55 & $100 \%$ & 0.72 \\
\hline U-N & Norwich & 45 & 21 & - & 0.47 \\
\hline TOTAL & & 314 & 205 & - & 0.65 \\
\hline
\end{tabular}

Table 5: Baptismal Fonts: Population 


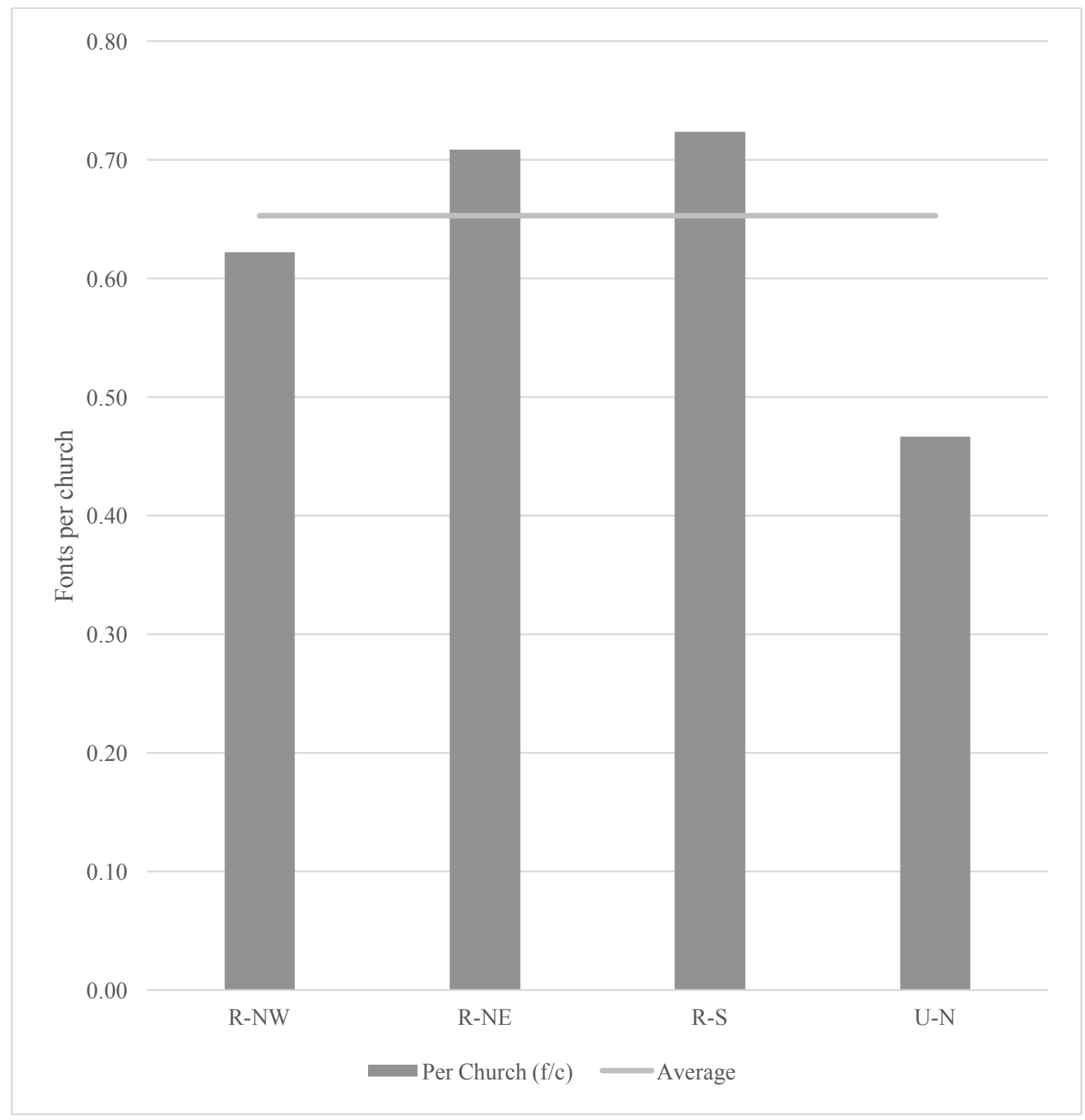

Figure 3: Baptismal Fonts: Per Church 


\begin{tabular}{|c|c|c|c|c|c|c|}
\hline & & R-NW & R-NE & R-S & U-N & TOTAL \\
\hline \multirow[t]{3}{*}{ Biblical } & Undamaged & 10 & 16 & 3 & 1 & 30 \\
\hline & Damaged & 5 & 2 & 3 & 3 & 13 \\
\hline & TOTAL & 15 & 18 & 6 & 4 & 43 \\
\hline \multirow[t]{3}{*}{ Extrabiblical } & Undamaged & 1 & 3 & 1 & 0 & 5 \\
\hline & Damaged & 8 & 10 & 4 & 4 & 26 \\
\hline & TOTAL & 9 & 13 & 5 & 4 & 31 \\
\hline \multirow[t]{3}{*}{ Secular } & Undamaged & 11 & 14 & 22 & 8 & 55 \\
\hline & Damaged & 1 & 2 & 1 & 0 & 4 \\
\hline & TOTAL & 12 & 16 & 23 & 8 & 59 \\
\hline \multirow[t]{3}{*}{ Decorative } & Undamaged & 16 & 42 & 43 & 18 & 119 \\
\hline & Damaged & 1 & 1 & 4 & 1 & 7 \\
\hline & TOTAL & 17 & 43 & 47 & 19 & 126 \\
\hline TOTAL & & 53 & 90 & 81 & 35 & 259 \\
\hline
\end{tabular}

Table 6: Baptismal Fonts: Iconography 


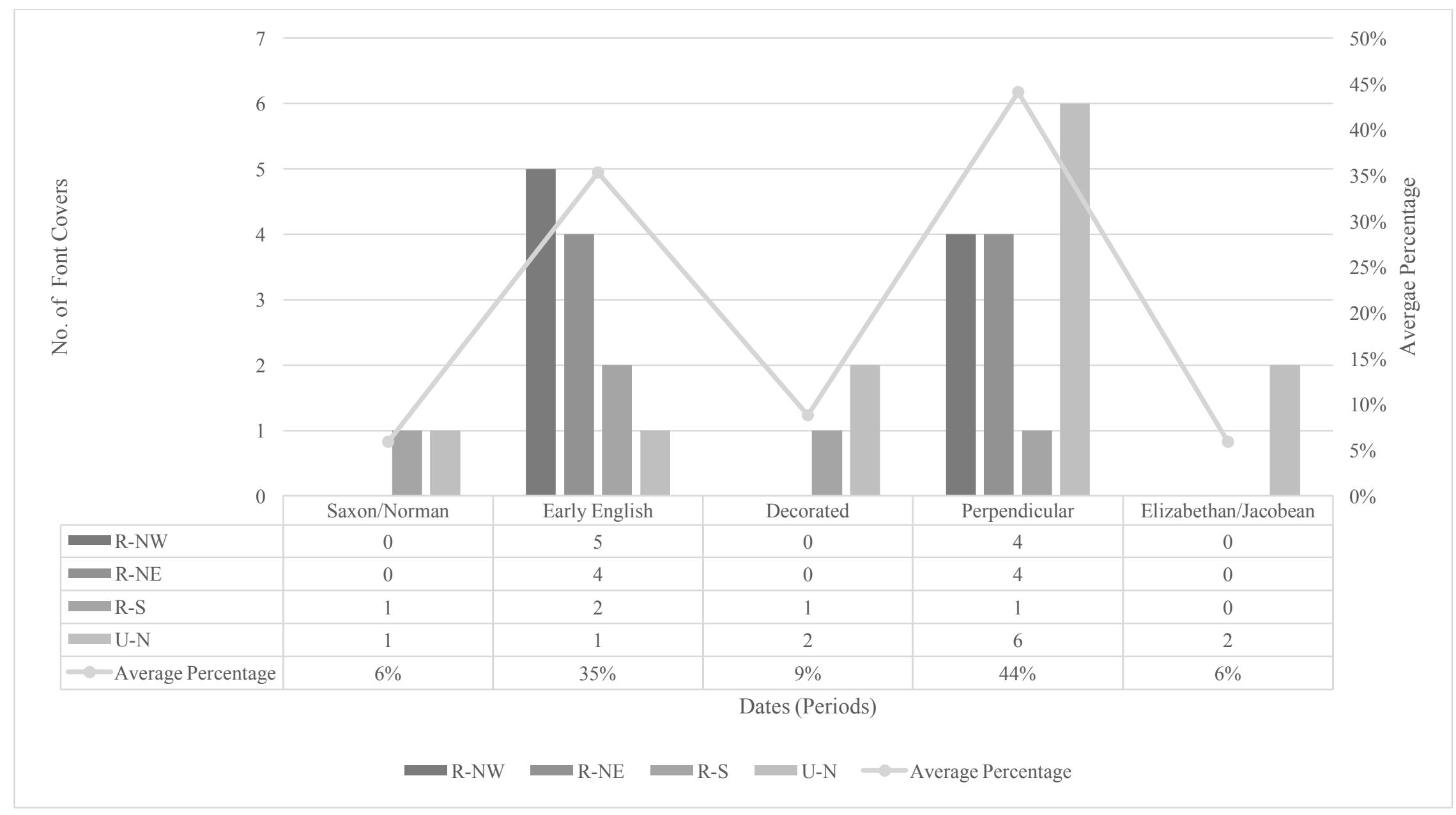

Figure 4: Baptismal Fonts Covers: Chronological Distribution 


\begin{tabular}{|c|c|c|c|c|c|}
\hline Sample & & Church & Covers & Percentage & Per Church \\
\hline & & (c) & $(f)$ & $(\% f)$ & $(f / c)$ \\
\hline \multirow[t]{6}{*}{ R-NW } & Brothercross & 10 & 0 & $0 \%$ & 0.00 \\
\hline & Freebridge-Lynn & 36 & 4 & $57 \%$ & 0.11 \\
\hline & North Greenhoe & 21 & 2 & $29 \%$ & 0.10 \\
\hline & Smithdon & 20 & 1 & $14 \%$ & 0.05 \\
\hline & King's Lynn & 3 & 0 & $0 \%$ & 0.00 \\
\hline & TOTAL & 90 & 7 & $100 \%$ & 0.08 \\
\hline \multirow[t]{5}{*}{ R-NE } & Blofield & 19 & 0 & $0 \%$ & 0.00 \\
\hline & South Erpingham & 39 & 3 & $50 \%$ & 0.08 \\
\hline & Taverham & 19 & 1 & $17 \%$ & 0.05 \\
\hline & Tunstead & 26 & 2 & $33 \%$ & 0.08 \\
\hline & TOTAL & 103 & 6 & $100 \%$ & 0.06 \\
\hline \multirow[t]{5}{*}{$\mathbf{R}-\mathbf{S}$} & Depwade & 23 & 2 & $25 \%$ & 0.09 \\
\hline & Diss & 16 & 2 & $25 \%$ & 0.13 \\
\hline & Guiltcross & 14 & 3 & $38 \%$ & 0.21 \\
\hline & Shropham & 23 & 1 & $13 \%$ & 0.04 \\
\hline & TOTAL & 76 & 8 & $100 \%$ & 0.11 \\
\hline $\mathbf{U}-\mathbf{N}$ & Norwich & 45 & 8 & - & 0.18 \\
\hline TOTAL & & 314 & 29 & - & 0.09 \\
\hline
\end{tabular}

Table 7: Baptismal Font Covers: Population 
0.20

0.18

0.16

0.14

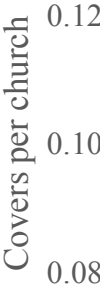

0.06

0.00
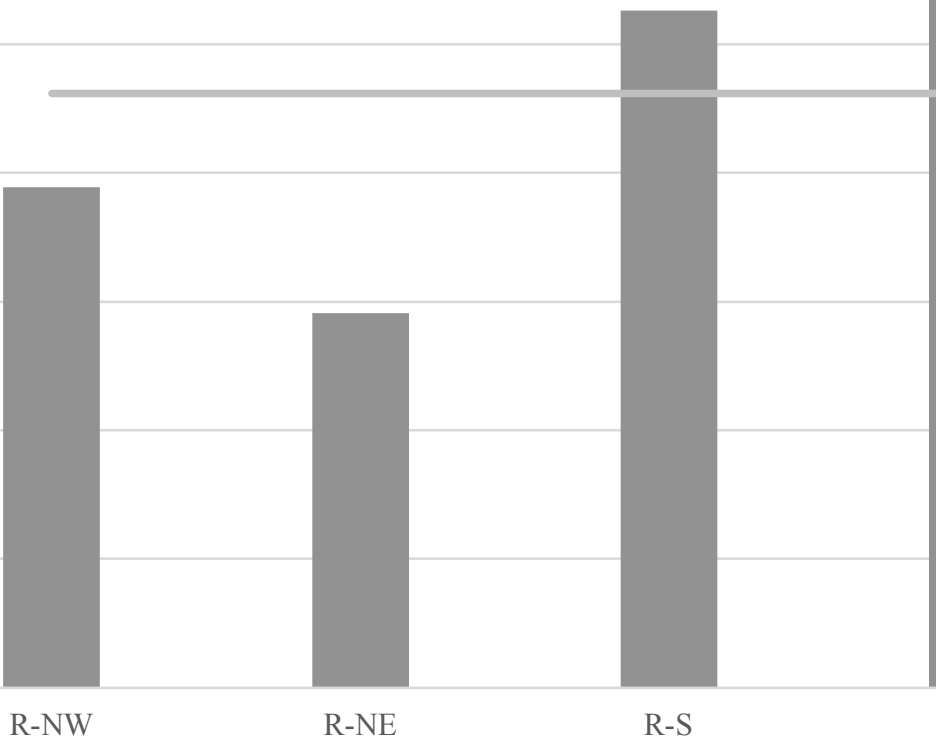

R-NE

R-S

U-N

Per Church (f/c)

Average

Figure 5: Baptismal Font Covers: Per Church 


\section{R-NW Sample}

This section will examine two medieval baptismal fonts located in the parishes of Castle Acre and Burnham Deepdale. While Castle Acre was selected for the aristocratic and monastic influence, Burnham Deepdale retains secular iconography that had strong appeal to the common laity.

\section{Case Study: Castle Acre}

The village of Castle Acre and its parish church consecrated to St. James, was under the influence and dominion of the local aristocracy since the establishment of William de Warenne as earl of Surrey following the Conquest. Eventually, this title converged with the powerful duchy of Norfolk, leaving the FitzAlan family, earls of Arundel, with control of the manor at the beginning of the Reformation. By the middle of the sixteenth century, this title was also conferred to the duke of Norfolk through the marriage of Mary FitzAlan to Thomas Howard. The role these prominent Catholic sympathizers, despite their frequent attainders during the period, must have had a conservative influence on the church, which had for centuries lived in the shadows of a prominent monastic institution.

Located between the remnants of a Norman castle and Castle Acre Priory, home to a Cluniac order established in the eleventh century and its own priory church, the parish church was constructed on the site of an Anglo-Saxon church, which had been granted to the monastery as part of its founding charter (Blomefield, 1808, p. 365). St. James Church contains a fine example of a surviving Perpendicular Gothic (c.1350 - 1520) stone font and elaborate wooden canopy, which was spared the extensive nineteenth century Victorian renovations. This font features a hexagonal bowl and stem fashioned from one piece of stone with carved rounded piping running down all six corners to the base (Plate 1); however, this fifteenth century fitting has been incorrectly identified as having a more common octagonal basin (Pevsner \& Wilson, 1999, p. 242). The font is raised two steps from the level of the pavement and devoid of any additional carvings, with its six panels most likely having been adorned with paint before the Reformation. Despite its plain motif, the shape of font offers another glimpse of how medieval religion made use of geometric expressions to convey deeper symbolism. Six-sided fonts can represent the sixth day of the Jewish week, which falls on the Friday before 


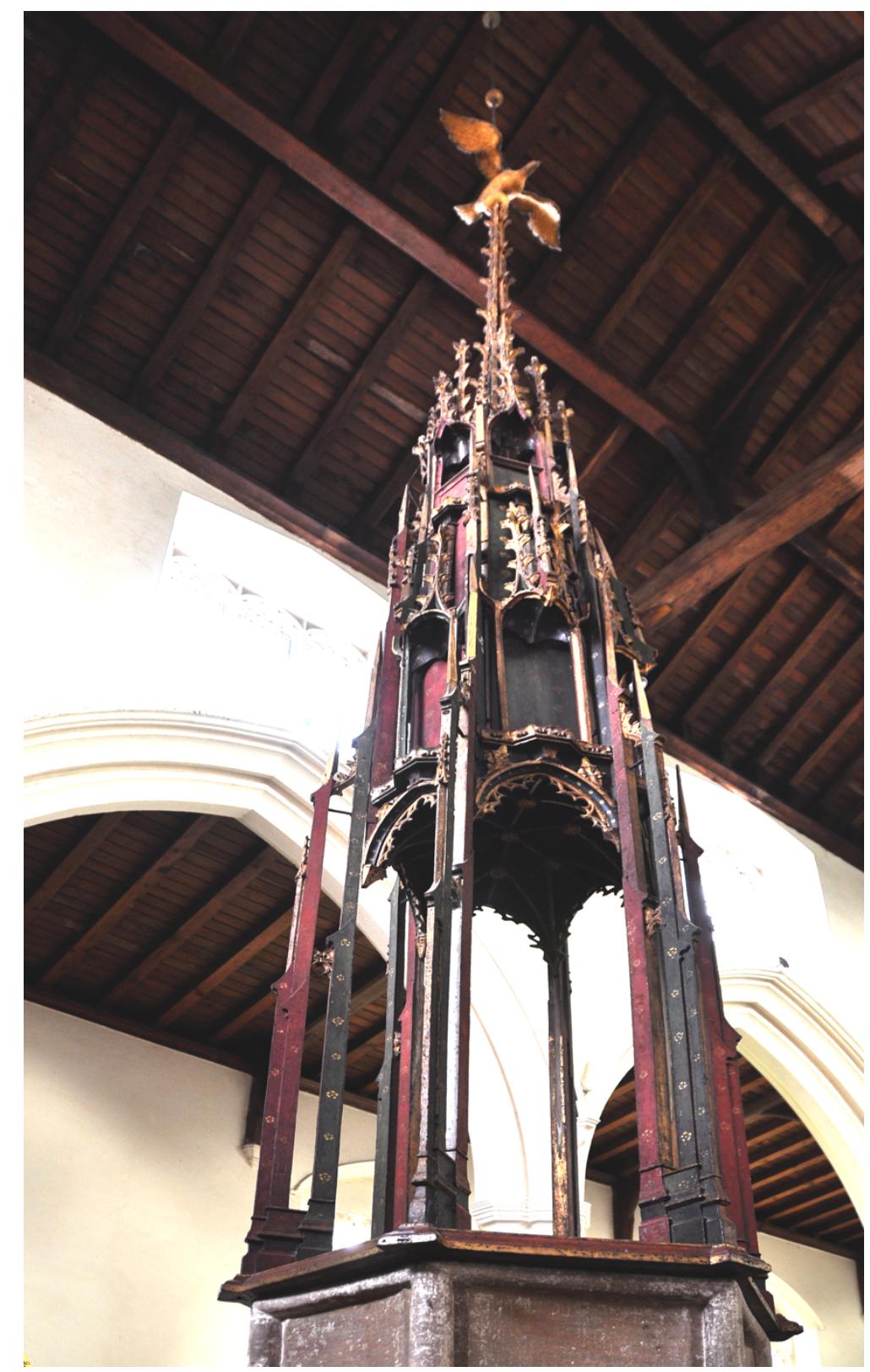

Plate 1: Baptismal Font Cover: Castle Acre

(Photo: Simon Knott)

the Sabbath. To Christians, this invokes the connection between the execution of Jesus Christ, the conquest of death through his sacrifice and empowering of the sacraments in order to obtain salvation. This notion of "being united with him in death" and "united with him in a resurrection" (Romans 6:3-5) is very closely aligned with the symbolism entwined with the sacrament of baptism (Kuehn, 2007, p. 65; Jensen, 2012, p. 162). 
The font at St James in Castle Acre is topped with a telescopic chestnut wood canopy, which may have originated as a furniture piece for the priory church, before its dissolution in 1537 (Knott, 2005). The elaborately carved spires are richly painted red and green with white and gold trim. In the mid-eighteenth century, the entire cover had its gilding retouched and painted solid red; however, the erosion of the layer eventually revealed its original colored motif. The bottom of the canopy has six intersecting barrel vaults, with its ribs retaining its gilt and red paint; golden stars are strewn across the dark blue paintwork. Reminiscent of a heavenly evening sky, the roof intersections support seven round bosses, which is another case of numerological significance in regards to the sacraments or day of creation. In his account of the castle and priory in the mid-nineteenth century, Reverend Bloom (1843, p. 286) suggested that a small sculpture of the Virgin and Child was situated in this space before being removed during the Reformation; yet, this seems unlikely as the space between the small vault ceiling and the actual basin lid would not leave enough vertical clearance for any such decoration (Howard \& Crossley, 1919, p. 385).

The tapering pinnacle of the exterior is filled with twelve empty niches, a larger and smaller shallow arch on each of the six sides, which most likely held little figures; however, empty spaces of this nature could also reflect an unfinished work (Bloom, 1843, p. 286). The counterbalance apparatus of this fitting is still operational, with its extensive system of cords and pulleys hidden by the elaborate wooden tracery. When the font was needed, the cover could be easily lifted by hand, with the open lower third of the canopy sliding upwards and remaining suspended until being lowered and reaffixed atop the basin. The ingenuity of this style of font cover may have contributed to its survival, as an appreciation for its engineering may have had wider appeal than that for artistic achievements. As a result, the canopy was spared with only the possible, and minimal, alterations of removing, as opposed to mutilating, the contents of the twelve niches. Despite being uncommon, other examples of a surviving telescopic cover can be found in Norfolk, including; Terringham and North Walsham; the latter is in the $R-N E$ sample group. 


\section{Case Study: Burnham Deepdale}

The parish church of St. Mary in the village of Burnham Deepdale has an uncommon Norman font free of any iconoclastic molestation (Plate 2). The building itself is the product of a series of post-Reformation construction projects, most notably during the Victorian period; however, a rare circular Saxon tower has endured at the west end. The parish was under the control of the prosperous Ramsey Abbey, home to a Benedictine order based in Cambridgeshire, since the second half of the twelfth century until, presumably, the Dissolution; a dynamic which demonstrates an alternative to the common scenario of a church being owned by a local aristocrat (Blomefield, 1807, pp. 9-11). Upon entering the building through the south doorway into the nave, a Barnack limestone font can immediately be seen. In the period of its creation, fonts with foursided basins were not uncommon, as the square form was prevalent in Norman architecture (Combe, 1844, p. 13). Fonts from this period account for $18.8 \%$ of the survivals in the sample, with seven out of the ten retaining their square basin; however, the actual number is eight out of ten as the octagonal font found in Ingoldisthorpe was originally square before being recut (Bond, 1908, p. 97). Rather than resting atop a Decorated Gothic (1250-1350) or Perpendicular Gothic stem, like the one at St. Lawrence at Castle Rising, this font retains its original pedestal consisting of four shafts with a central support column. Unlike the previous fitting discussed, this font retains its visual adornments, in the form of extensive carvings. The square exterior has a large lip around the perimeter with common depictions of foliage, and a lion etched into the stone. Beneath this lip, three of the four panels show depictions of common rural toil through the twelve months of the year. This 'Labours of the Months' motif was a common medieval representation associated with decorative calendars and integrated common astrological signs with a Christian view of universal order (Calkins, 1983, pp. 245-246).

Three sides of the font are carved with four shallow arch niches containing a figurative relief, for a total of twelve, the fourth side remaining uncut. The months of the year wrap around the perimeter in a counter-clockwise from the north to east to south side. This distribution of the months across the three sides of this font, as opposed to all four, was most likely a result of the master sculptor knowing that one panel would be obscured if the fitting was placed near or against a wall. The original in situ position of 


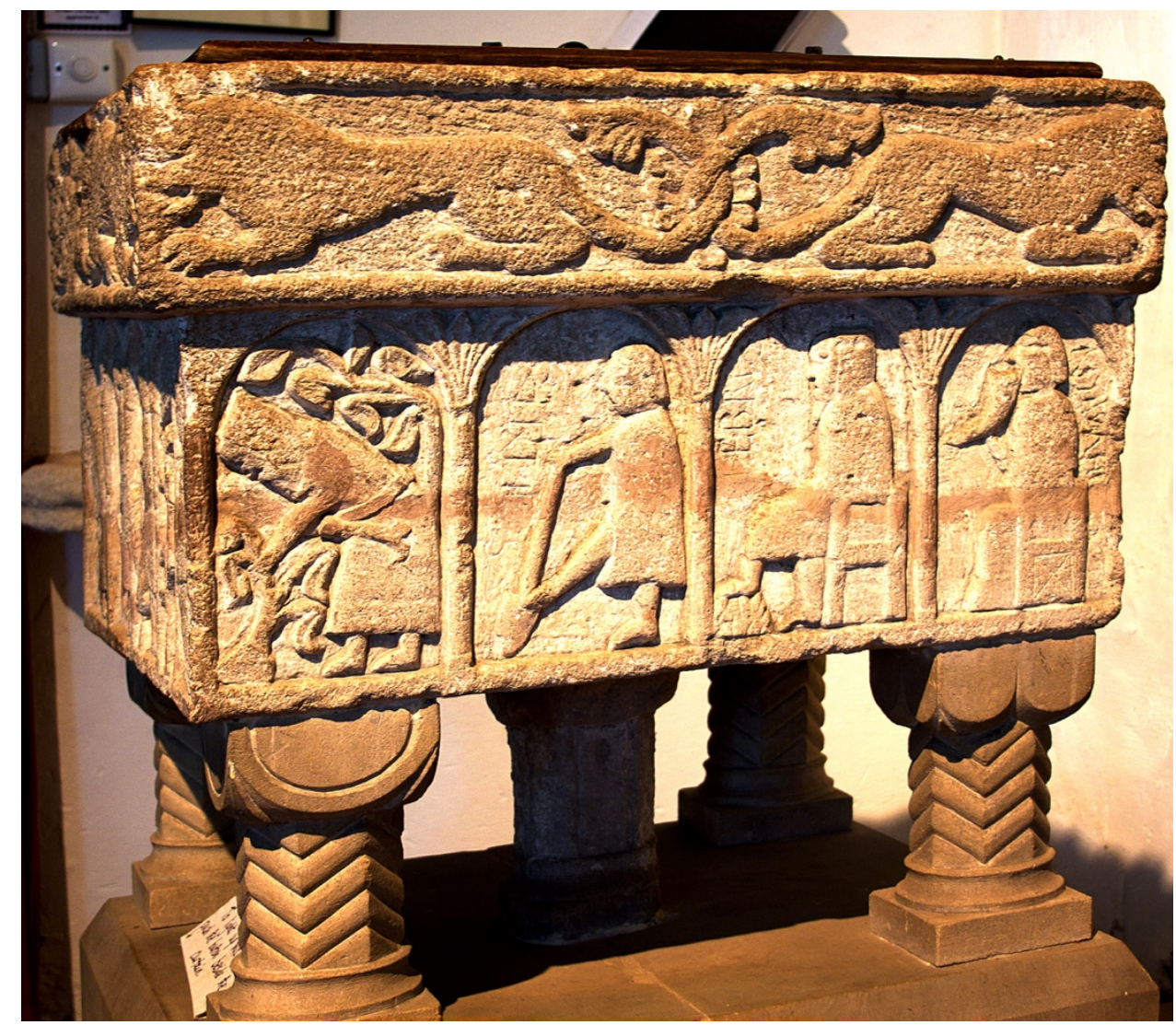

Plate 2: Baptismal Font: Burnham Deepdale

the font is not entirely clear, as it has been moved many times, including as late as the eighteenth century, which resulted in it being dropped, broken, discarded, recovered and restored; however, the nature of the carvings do suggest that it was designed to have one of its sides against a wall (Astley, 1907, p. 104).

This motif was flexible in terms of the rural labors on display and usually catered to the region which, in the case of the $R-N W$ sample, was dominated by the cultivation of corn and grazing of sheep, which resulted in more modest landholding parcels. The north panel depicts the first four months of the year: January, a man imbibing from a horn while sitting; February, a man sitting; March, a man beginning to work the ground with a shovel; and April, a man trimming a vine. The east panel shows the next four months: May, a man celebrating the Rogation Days before the Feast of the Ascension or pruning a tree (Paul, 1903, p. 54); June, a man weeding; July, a man working the ground with a hoe or scythe; and August, a man bundling a sheaf of corn. The south panels close out the year: September, a man harvesting his crops; October, a man grinding his corn, or 
perhaps brewing (Paul, 1903, p. 54); November, a man slaughtering a pig; and December, depicting four men seated for a feast. The remarkable nature of this font is the clear picture it presents of rural life in medieval Norfolk, complete with not only labor but also leisure.

Despite the medieval iconography on display, the cause of survival of this particular font appears to be three-fold. The first two reasons tie directly into a greater theme being demonstrated in this work; that the fitting was still a liturgical necessity and the subject matter of the iconography was theologically neutral. The third is related to the unique imagery, which suggests an intimate connection with the common parishioners, as it was one of the rare cases where their lives and experiences were immortalized in stone as opposed to a commemoration of historically significant saints or rituals. This collective connection opens a new populist dimension to the analysis of iconographic depictions, with the notion of that the people were accepting of decoration appealing directly to them by honoring their accomplishments, which was often limited to their drudgery.

\section{R-NE Sample}

This section examines two medieval baptismal fonts located in the parishes of Sloley and Irstead. The Sloley font retains a seven sacrament motif, accompanied by more symbolic representations culled from Scripture; while the Irstead fitting features more complex Christological iconography. These two cases were selected for their unique iconography that demonstrates the use of Pierce's theory of sign, with the liturgical and Christological representation as icons and the use of animals representing the evangelists as symbols.

\section{Case Study: Sloley}

The rural parish of Sloley demonstrates the influence a conservative gentry family could exert over not only the creation of church fittings but their subsequent survival throughout the Reformation. By the eleventh century, a small settlement of about 26 families was already in place, as recorded in Domesday; the primary landholders were the abbot of St Benet's Abbey at Hulme, home to a Benedictine order, and the Beaufour family. By the middle of the twelfth century, Sir Reginald le Gross emerged as the 
tenant-in-chief and established his family as one of the major landholding families in Norfolk. The fifteenth century saw an increase in building in and around the village financed by the Gross family, including the rebuilding and expansion of St. Bartholomew Church, atop the original Norman structure, and the conversion of Old Sloley Hall into the manor of the estate. The influence of the Gross family in the parish during this period can be seen in the south aisle of the church, which was extended to accommodate the altar tomb of Oliver le Gross in 1439, who willed additional funds to further repair the building (Blomefield, 1810, pp. 60-62).

Blomefield (1810, p. 62) does offer an interesting glimpse into religious life at Jacobean Sloley, as a Thomas Grymes presented the rector to the parish as opposed to the usual trend of being presented by the leading member of the Gross family, who remained prominent until their estates in Sloley and Crostwich were sold to the Walpoles in the early eighteenth century. There are no records chronicling what exactly transpired during the early phases of the Reformation, but a conservative influence can be observed in the surviving Perpendicular Gothic font found in St. Bartholomew (Plate 3). This fitting, which was possibly commissioned as late as the mid fifteenth century, features unmolested carvings depicting the seven sacraments and the baptism of Christ, with the lower basin and stem adorned with eight angels, flowers, and the four evangelists. This is one the best preserved medieval fonts featuring an undamaged sacrament motif, along with another found at Gresham (Bond, 1908, p. 259). 

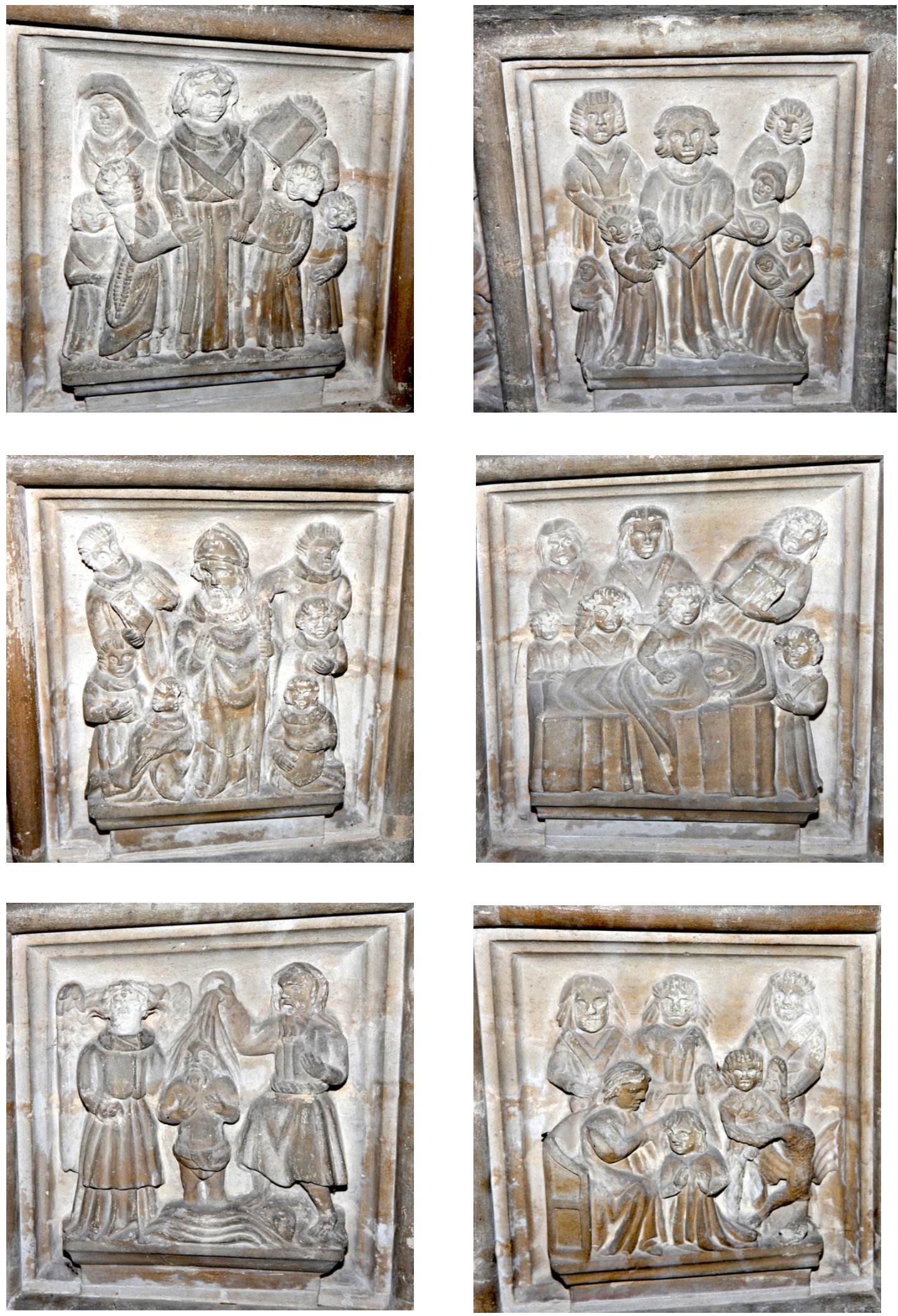

Plate 3: Baptismal Font: Sloley 
Seven panels of the octagonal basin are each carved with a likeness of the seven sacramental rites of the Catholic Church, with the eighth of Jesus being baptized, an appropriate and common choice of this remaining panel (Matthew 3.13-17, Mark 1.911, Luke 3.21-23, John 1.29-33). The upper portion of the stem is adorned with eight carved angels beneath the basin and at the base, each of which is holding a blank heraldry shield. The stem and base feature strong iconography, which conveys respect and an emphasis on both Scriptural and secular authority, as the eight sides have alternating carvings of the four evangelists and four floral heraldic emblems, most likely the Tudor rose. This elaborate stem terminates with four protruding statuettes at the base, each of which originate from the angelic tetramorph that pulls the chariot of God as described in the Book of Ezekiel and again referenced in the Book of Revelation (4.6-9); although, Pevsner (1999, p. 665) oversimplifies this decoration by only referencing the figures as small lions. This common medieval iconographic convention equates the four beasts with the four evangelists: Matthew, a man who embodies wisdom; Mark, a lion that represents courage; Luke, an ox who evokes the sacrificial component of faith; and John, an eagle to remind the faithful of the heavenly and eternal nature of Christ. These creatures, all of whom were regarded as masters of their grouping, are visual metaphors for the essence of Jesus, but also the attributes necessary for salvation (Lanzi \& Lanzi, 2004, p. 16; Mâle, 1973, p. 2).

\section{Case Study: Irstead}

The rural village of Irstead, located near the Barton Broad, part of the labyrinth of rivers and lakes known as the Broads, is home to an early fourteenth-century church dedicated to St. Michael. Within a century of its founding, the church obtained an outstanding stone baptismal font set atop a two-step octagonal base (Plate 4). The most remarkable feature of this fitting is the sculpted motif found across the eight panels of its tall basin. Unlike Sloley, this font forgoes the sacramental motif in favor of a biblical scheme, which remained unmolested throughout the sixteenth and seventeenth centuries. The eight basin panels feature four content carvings alternating between panels adorned with only a decorative floral pattern. The four subject panels all evoke either a figure or theological imperative found in scripture. Firstly, the eastern side portrays the face of Christ within a cruciform nimbus, set atop a backdrop of clouds, with traces of its original blue copper coloring visible. It has been suggested 
inspiration for this particular rendition appears to have been the Volto Santo, or the veil of Veronica, a medieval relic akin to the Turin shroud (Bond, 1908, p. 253); however, the rather general nature of the image leaves this view unsubstantiated. Secondly, the southern side presents another bearded visage, which at first glance appears to be another version of Christ, encircled with a nimbus; however, a closer examination reveals that the halo encircles the entire head past the chin. This makes it far more likely the face in question is that of John the Baptist, with the circular shape representing the plate on which his severed head was presented (Matthew 14:10-11, Mark 6:14-29). The designer of the font was most likely aware of the potential for confusion between the two faces, which is why the aforementioned face of Jesus had the cruciform added for visual distinction. Thirdly, the west side features a divine hand stretching down from the sky holding what appears to be a scroll. It is interesting to observe that this carving, which is clearly depicting the transference of Mosaic Law from God to mankind, is on a panel opposite that of Christ, who spoke of being the fulfillment of the Law (Matthew 5:17-18). Furthermore, in a period where spatial sacrality was integral in the design and furnishing of a consecrated space, the choice to have Christ facing the chancel, while the Law faces away, is a subtle but powerful testament to the priorities of medieval Christianity. Finally, the northern panel is a clear representation of the Agnus Dei, or Lamb of God, which is a biblical trope for Jesus as the sacrificial conqueror of iniquity (John 1:29). The image itself was a common icon in medieval Christology, with the lamb carrying a war flag topped with an empty cross. This particular iteration of the image retains the shaft but not the flag itself; however, the lamb has a halo surrounding its head, another common component of the iconography. Both the shaft and halo retain some of their original blue bice, a term for colors comprised of copper salts (Thompson, 1956, pp. 152-53).

The Irstead font is another example of the type of religious motifs that commonly survives reforming, and later puritanical, iconoclasm. In addition to being spared any physical molestation, the traces of original color suggest that the fitting avoided being whitewashed, a characteristic rarely found on octagonal fonts. In a smaller rural parish, such as Irstead, the possibility looms that the survival of church fittings was unrelated to the broader religious imperatives of the period due to its remote location; however, this dynamic would provide even greater context for how the parishioners saw and 
reacted to the Reformation, without the influences of waves of commissioners making their visitations. In the case of this parish, iconographies, depicting biblical figures, events or symbols, were considered acceptable visual representations of the transforming religious doctrine.
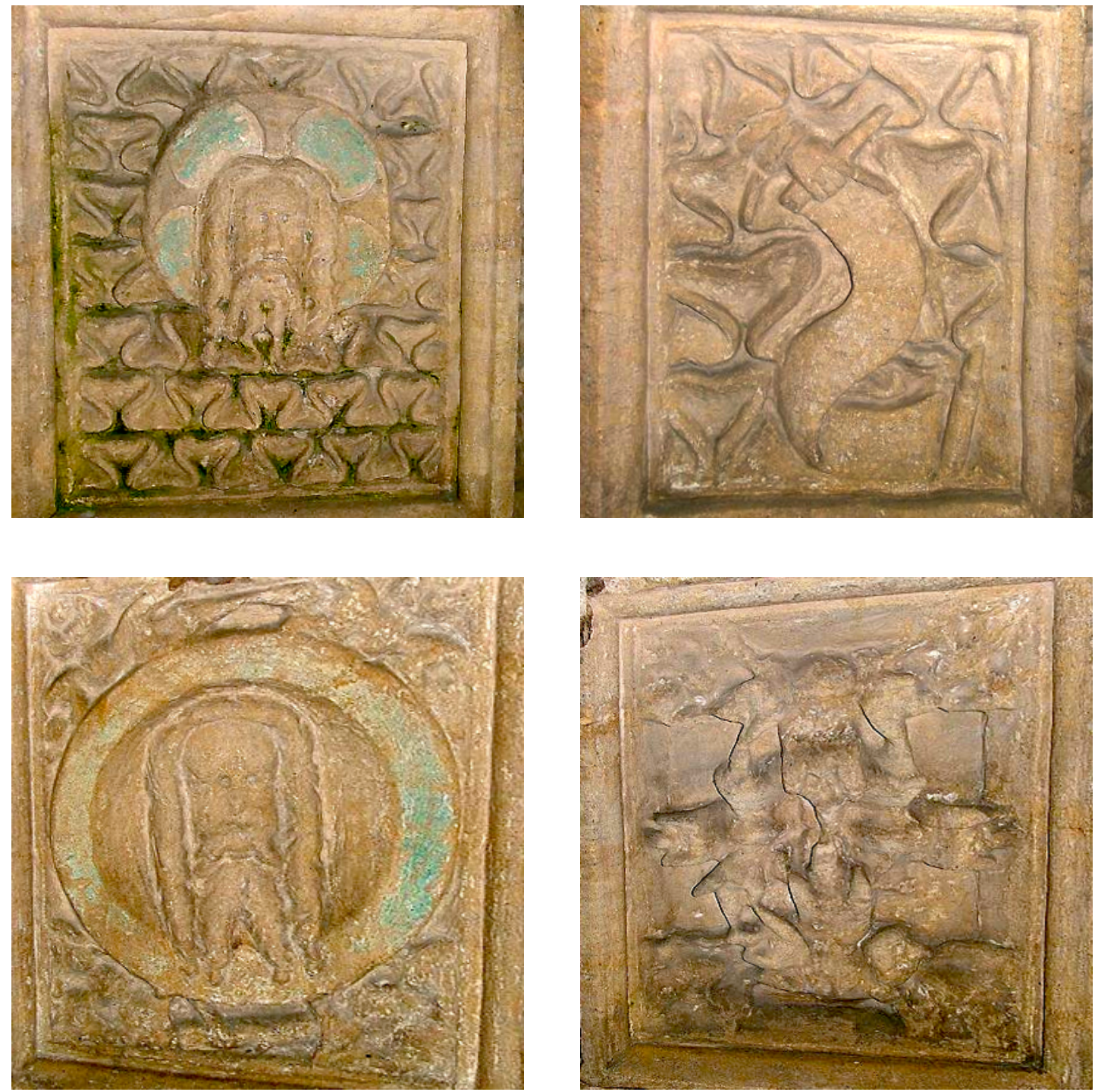

Plate 4: Baptismal Font: Irstead 


\section{R-S Sample}

This section will examine two medieval baptismal fonts located in the parishes of Blo Norton and Shimpling. Both cases were selected for the use of symbol tied to the Bible as opposed to orthodox tradition. Shimpling builds on the evangelist motif seen at Sloley, with the addition of the heraldic use of objects associated with the Passion of the Christ. Blo Norton was selected for its unusual use of Jewish iconography, allowing an opportunity to address the Norfolk Jewry and the role that a biblical-centric worldview of Puritans during the seventeenth century Commonwealth had on the resettlement.

\section{Case Study: Blo Norton}

The remote parish of Blo Norton, located near the southern border between Norfolk and Suffolk, has a small village church consecrated to St. Andrew. This parish was divided between three distinct types of landlord: aristocratic, franklin, or freemen, landowners, such as the earls of Surrey from Brome Hall Manor and Alsius from his manor in Lopham, respectively, and monasteries, such as Bury St Edmunds Abbey and Ely Cathedral (Blomefield, 1805, pp. 242-249). The role of these varying forces must have created a sense of perpetual uncertainty for the rector of St. Andrews, which could only have been exacerbated as the ownership of the monastic holdings transitioned to private hands following the Dissolution. Like so many churches, the interior of the building was transformed by Victorian restorations, with a fourteenth-century granite baptismal font remaining as the only medieval fitting (Plate 5). Rather than iconographic depictions, the octagonal basin and central shaft are adorned with carvings that are semiotic in nature. Beyond the quatrefoil, heraldry, and tracery, one of the eight panels features a rare six-point Magen David, more commonly known as the Star of David. Observers have speculated that this use of a Jewish symbol may have been part of a sixteenth-century modification, which still would have been an unusual addition to a piece of Christian furnishing in a country that expelled its Jewish population through legislation almost three centuries earlier (Pevsner \& Wilson, 1999, p. 209). This font offers a rare glimpse into the period between the beginnings of the Reformation and the resettlement of Jews in England the following century under the commercial and religious policies of Cromwell's Protectorate government. A practical explanation for the inclusion, and survival, of this symbol is a fraternal kinship 
resulting from a Protestant ethic regarding the Bible, which is primarily a chronicle of God's covenant with the Jewish people until its fulfillment and transformation in the New Testament. The ethnic identities of many Biblical figures were obscured and recontextualized in visual depictions produced in medieval Christendom; however, the shift towards a literate faith lifted the veil and made it quite difficult to marginalize the Jewish influence.

A survival of this nature is especially remarkable considering the complex relationship between the Norwich Jewry and English Christians, specifically during the first decade of the establishment of a prominent Jewish community in the city. In 1144, the body of a thirteen-year-old boy named William was discovered outside Norwich in Mousehold Heath, part of Thorpe Wood. Everard of Calne, Bishop of Norwich during the period,
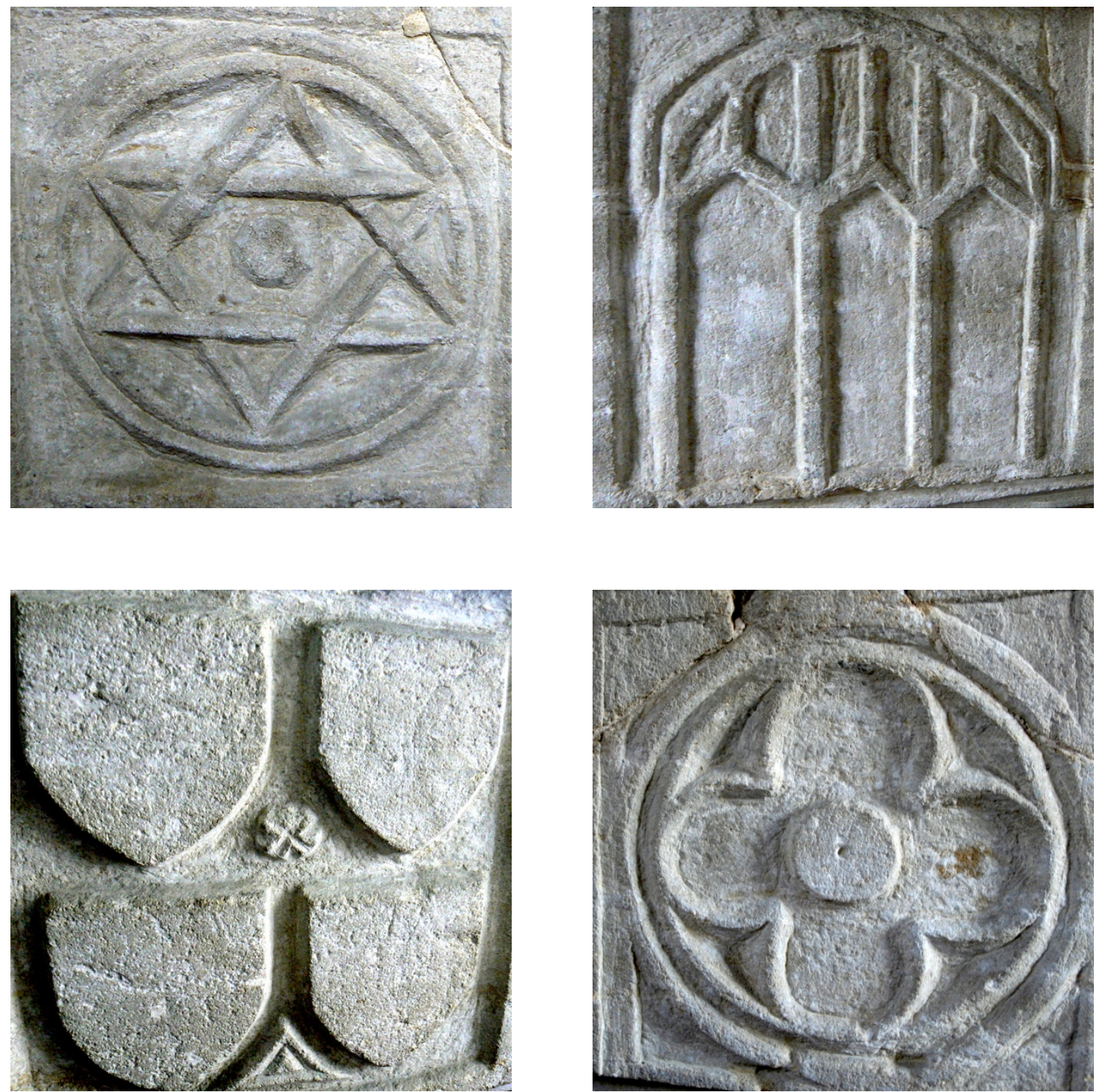

Plate 5: Baptismal Font: Blo Norton 
horrified by the early emergence of a cult which exploited a tragedy for the sake of inciting further hatred and violence, resigned from the episcopacy in favor of monastic life in 1145. At the instigation of his successor, William de Turbeville, a formal cult to William's martyrdom emerged, as the body became an object of veneration and was relocated several times until finally installed in a shrine at Norwich Cathedral.

In 1150, an investigation of the murder was conducted by Thomas of Monmouth who determined that the boy had been ritualistically tortured and slain by the local Jewish community in accordance with a prophecy, which required the annual sacrifice of a Christian child in exchange for the eventual return of Israel (Jessopp \& James, 1896). These reports were circulated throughout the kingdom and resulted in massacres against Jewish communities, notably at London and York. At Norwich, the local nobility sought to suppress any unjust reprisals again Norwich Jewry, culminating in a full revolt. As these local uprisings intensified, the county sheriff garrisoned the Jewish quarters before temporarily relocating them within Norwich Castle; those who failed to find sanctuary were massacred.

This chain of events not only ignited further anti-Semitism but also strained the relationship between the people and the local authorities, who were seen as acting outof-step with popular sentiment with their defense of Jewish lives. In spite of centuries of separation, the emergence of a Jewish symbol on a sacramental fitting is a remarkable testament to a possible shift in attitude ushered in by the later phases of the Reformation.

\section{Case Study: Shimpling}

The rural setting of Shimpling, located to the east of its sister village of Burston, is the home to a church dedicated to St. George, located south of the village proper. It is worth mentioning the round thirteenth century tower topped with a fifteenth century octagonal belfry (Pevsner \& Wilson, 1999, p. 644), although a broader assessment of medieval masonry in East Anglia and a comparative look at similar towers in the area, such as All Saints in Thorpe Abbotts, suggest a later fourteenth century date (Hart, 1872, p. 138). The interior of the building has a richly decorated stone baptismal font, which retains its original panel incisions on the octagonal bowl and sculpted figures 
around the stem (Plate 6). The fitting dates to the fifteenth century and was possibly commissioned when the church bells were restored following an endowment provided by Matilda Goodwyn in 1466 (Cattermole \& Cotton, 1981-83, p. 264). An alternative possibility is that this font originated in another parish, as Blomefield's (1805, pp. 154161) account describes a different font featuring carvings of St. George, the dragon and the arms of Shimpling.

The eight sides of the bowl retain unmolested carvings on each panel, all of which take their creative inspiration from the canonical Gospel. Every other design is a carved
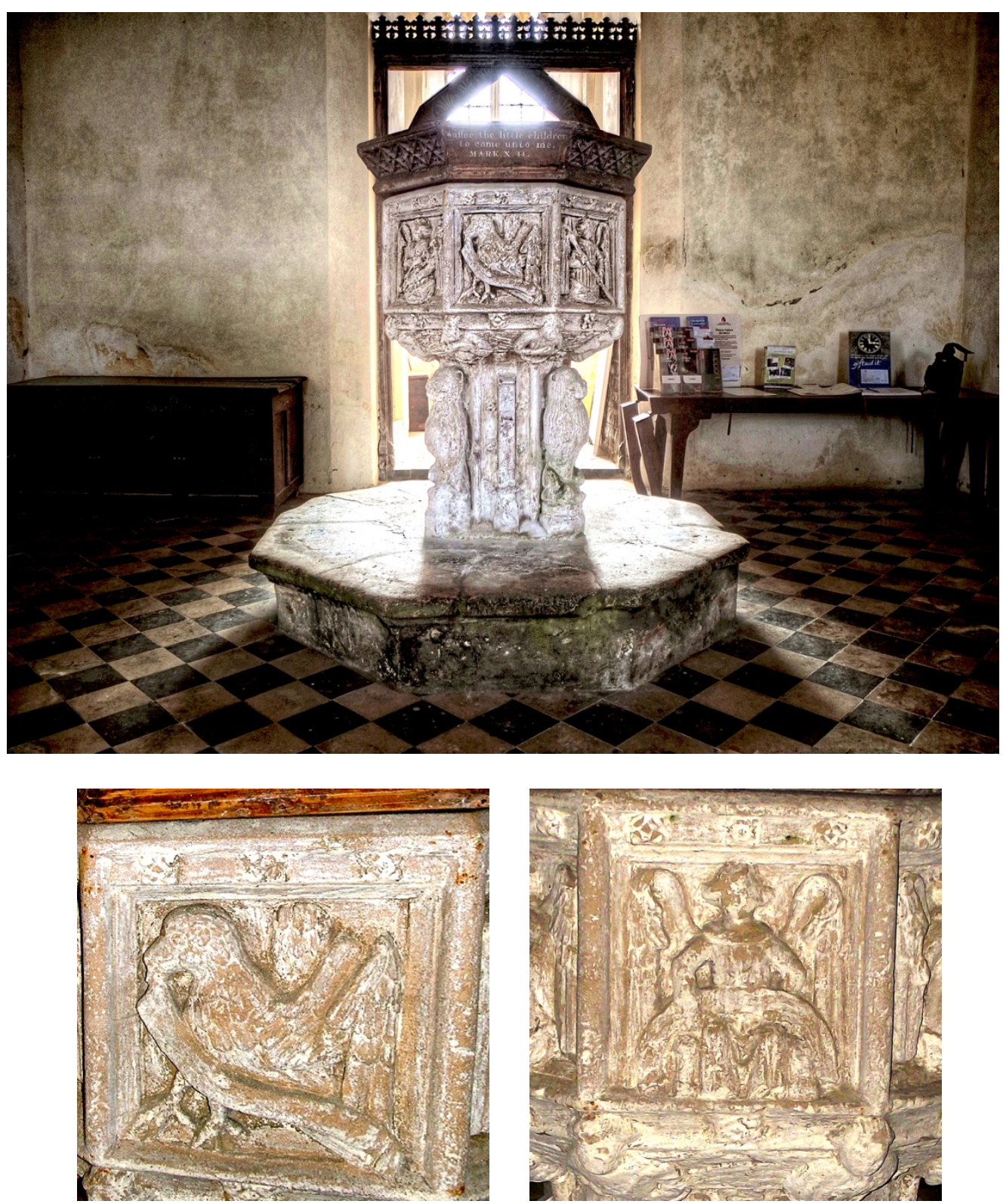

Plate 6: Baptismal Font: Shimpling 
symbol for one of the four evangelists; Matthew, Mark, Luke and John. With a renewed Protestant emphasis on Scripture, the authors of the most vital and sacred pieces of writing were more than worthy of commemoration. Similar to the Sloley font, the evangelist motifs, specifically in their symbolized form, proved to be a resilient set of iconography.

The four remaining alternating panels are adorned with another collection of Christian heraldry known as the Arma Christi, or instruments of the Passion. Each image features an angel holding the objects; a ladder used to take the body down from the cross; the crown of thorns; the spear used to pierce his side; and the hammer, nails, and pincers. These articles are a series of items associated with the brief time in the life of Jesus between his arrival in Jerusalem and execution at the hands of Roman authorities. These objects, all referenced in the Gospels, evolved into heraldic symbols representing weapons used in the subjugation of Satan following the Resurrection. England had a long tradition with the motif as the Utrecht Psalter, a ninth century illustrated manuscript which contains an early representation of the iconography, was in possession of Canterbury from before the Conquest through to the Dissolution (DeWald \& Wilde, 1932). Furthermore, the Middle English poem O Vernicle’ was often reproduced as an illustrated manuscript containing visual depictions of instruments (Cooper, et al., 2014). Recent studies of the Arma Christi in England suggest that increased popularity of this form of iconography aided in sparking a reliquary tradition that influenced the devotional practices and contributed to altering the relationship between structure and agency in medieval religion (Gayk, 2014, pp. 275-79). Many of these traditions, especially those related to relics, were among the earliest to be targeted and eradicated by the various schools of reform which emerged across Europe. Gayk argues that the transformation of how these symbols were to be interpreted arose in the Reformation tradition; a historical, and still heraldic, representation rather than a sacred source of miracles.

Shimpling's close proximity to northern Suffolk allows for a cursory look at the career of William Dowsing, the Puritan commissioned to carry out acts of iconoclasm in parish churches across Cambridgeshire and Suffolk on Parliamentary orders during the First English Civil War. In the detailed account he produced during this period, he 
mentions the Arma Christi font stonework in reference to five different churches. This ornamentation, which he often mentions in conjunction with symbols representing the Trinity, went mostly unmolested with only one font having its iconography defaced (Cooper, 2001, pp. 288-290, 292, 295). This should come as no surprise, as the 1643 Parliamentary Ordinance only highlights crucifixes, the Virgin, superstitious inscriptions and depictions of saints as unacceptable, with angels added the following year. This passive assessment by a sanctioned iconoclast during a period, which saw the excesses of material destruction, indicates an acceptance, or at least tolerance, for images tied to a biblical interpretation of Christianity.

\section{U-N Sample}

This section will examine three medieval baptismal fonts located in the Norwich parishes of St. John de Sepulchre, St. Gregory and All Saints Westlegate. The fonts examined at St. John de Sepulchre and St. Gregory feature symbolic iconography, while the one at All Saints Westlegate has a predominately New Testament biblical motif.

\section{Case Study: Norwich: St. John de Sepulchre}

St John the Baptist and the Consecration of the Holy Sepulchre, or simply St. John de Sepulchre, was unique in medieval Norwich, as it may have been one of the more independent parishes in the city. This can be attributed to its distance from the primary hubs of authority in the city, ecclesiastical and secular, as it is situated on the southern city wall near Berestrete Gate. Although this would be the church on display to visitors arriving from London, it was not necessarily indicative of city trends. The building retains an unmolested late Perpendicular Gothic font, which has its octagonal bowl adorned with four lions and four angels on alternating panels; the stem continues the bowl motif with four seated and laughing lions (Plate 7). While this form of iconography is usually associated with rural fonts, as seen in Shimpling and Sloley, it is possible that the more remote nature of this urban parish can be attributed to both the motif and its ultimate survival. The biblical association of the lion with Christ could be an explanation for the unmolested survival of this fitting, as well as three additional lion fonts found at St. Gregory, St. Peter Parmentergate and St. Swithin respectively. The wealthy, and literate, merchant class in Norwich could see for themselves in a 
vernacular translation of Scripture that forces of good and evil are both associated with the lion in a series of references beyond merely the visual representation of Mark the Evangelist. The earliest biblical reference can be found in Genesis 49.4, where the patriarch Jacob is promised that his descendants through the tribe of Judah will be like a lion, a reference that Christianity came to interpret as a prophecy anticipating the

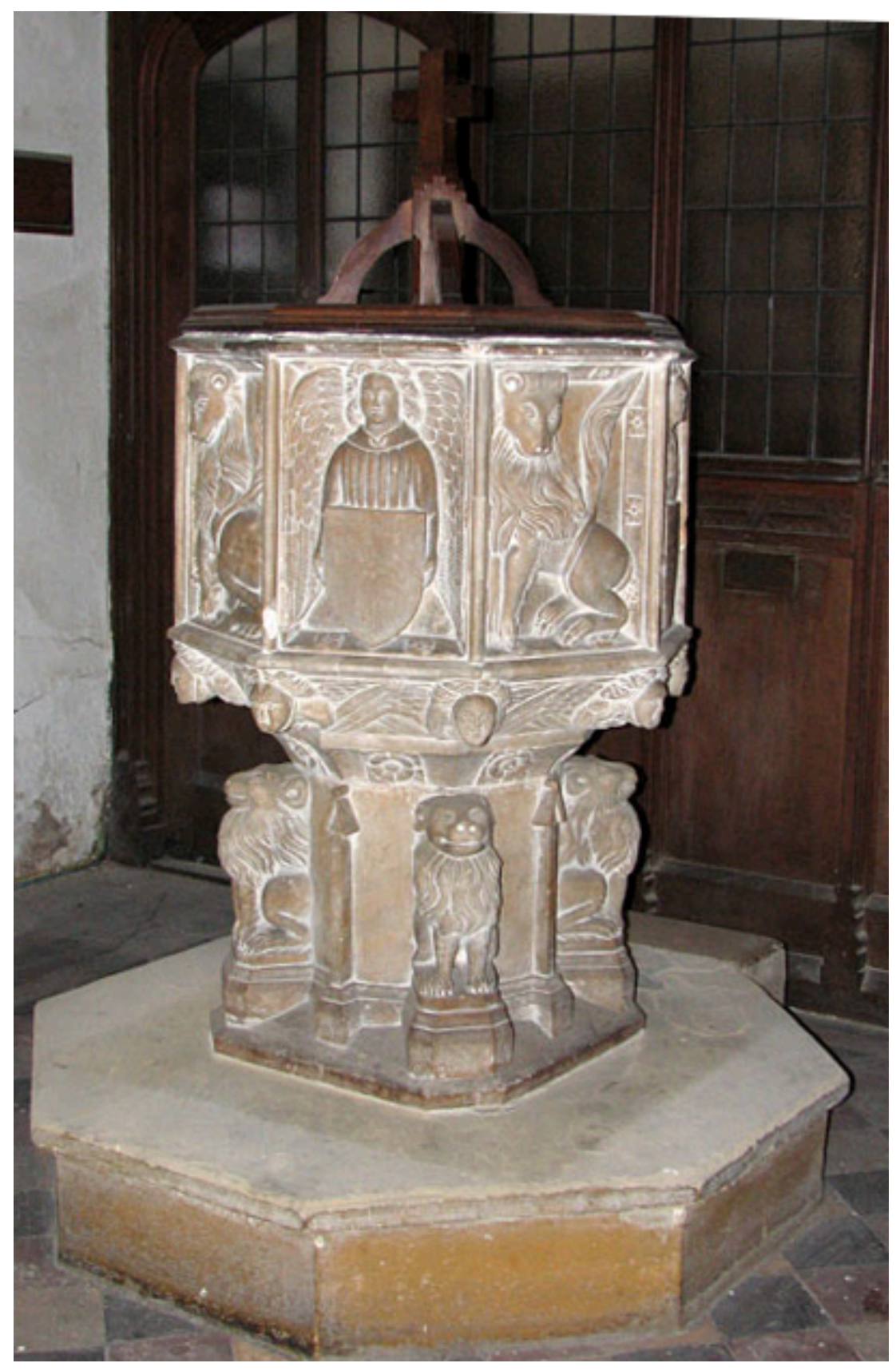

Plate 7: Baptismal Font: Norwich St John de Sepulchre

(Photo by: Evelyn Simak) 
messiah in the form of Jesus. Furthermore, the attributes of a lion are continually used metaphorically, such as to convey the strength of God's voice and justice, or even prowess as a hunter (1 Peter 5.8). While the role of the lion in antiquity must have shaped these passages, the belief in the authoritative nature of the Bible embraced by Calvinist, and previously Lollard, theology must have played a role in the icon's survival on this font. The veneration of saints had occurred under the authority of the Catholic Church, the symbol of the lion and the divine sacrality of angels were referenced in the Word. It could be argued that the reformers and Puritans did equate the lion iconography with Christ. The sense of divine justice and righteousness promoted by Puritan reformers may have led to a deep fascination with the Book of Revelation. In Revelation 5.5, Christ is referred to as the 'Lion of Judah.' The reverence for icons depicting Christ, or popular passages from scripture, is a trend which begins to emerge from an appraisal of medieval survivals. This appears to be true regarding the motif, which is also present in a more rustic form on the font located at St. Peter Parmentergate, and on a font removed from St. Swithin in the modern period (Groves, 2010 , p. 134). While the objects were theologically purged of their sacred nature through the implementation of new doctrine, they still served as a visual representation of the Word.

The quatrefoil motif, carved onto a quarter of the surviving fonts in Norwich, could occasionally be interpreted as leaves; however, this four-lobed symbol evokes the crucifix within a Christian context. St. Martin at Palace, a parish church with a heritage that predates the Conquest and evidence for an early Norman bishop's palace, retains a fourteenth-century font with undamaged quatrefoil carved on each side of its octagonal bowl. While some of the more excessive iconoclasts could have targeted the decoration on the grounds that the symbol was an idolatrous cross, it can be assumed that quatrefoils were often perceived as an inoffensive symmetrical carving on a necessary piece of church furniture. This is further evident by the five additional surviving fonts in Norwich to retain their original quatrefoil decoration. 


\section{Case Study: Norwich: All Saints Westlegate}

All Saints Westlegate, a smaller urban church constructed in the thirteenth century before being greatly renovated in the fifteenth century, was declared redundant in the mid-1970s and had its surviving fonts moved to St. Julian, which had lost its angeladorned baptismal furnishing in the blitz. The font is dated to the early fifteenth century and appears to have been contemporaneous with the nave and aisle construction previously mentioned (Plate 8 ). The octagonal bowl is decorated exclusively with biblical effigies of the twelve apostles and four evangelists distributed two per panel. The stem is adorned with eight additional biblical figures, including St. Paul, St. John the Baptist and St. Michael, and an extra-biblical representation of St George of Lydda

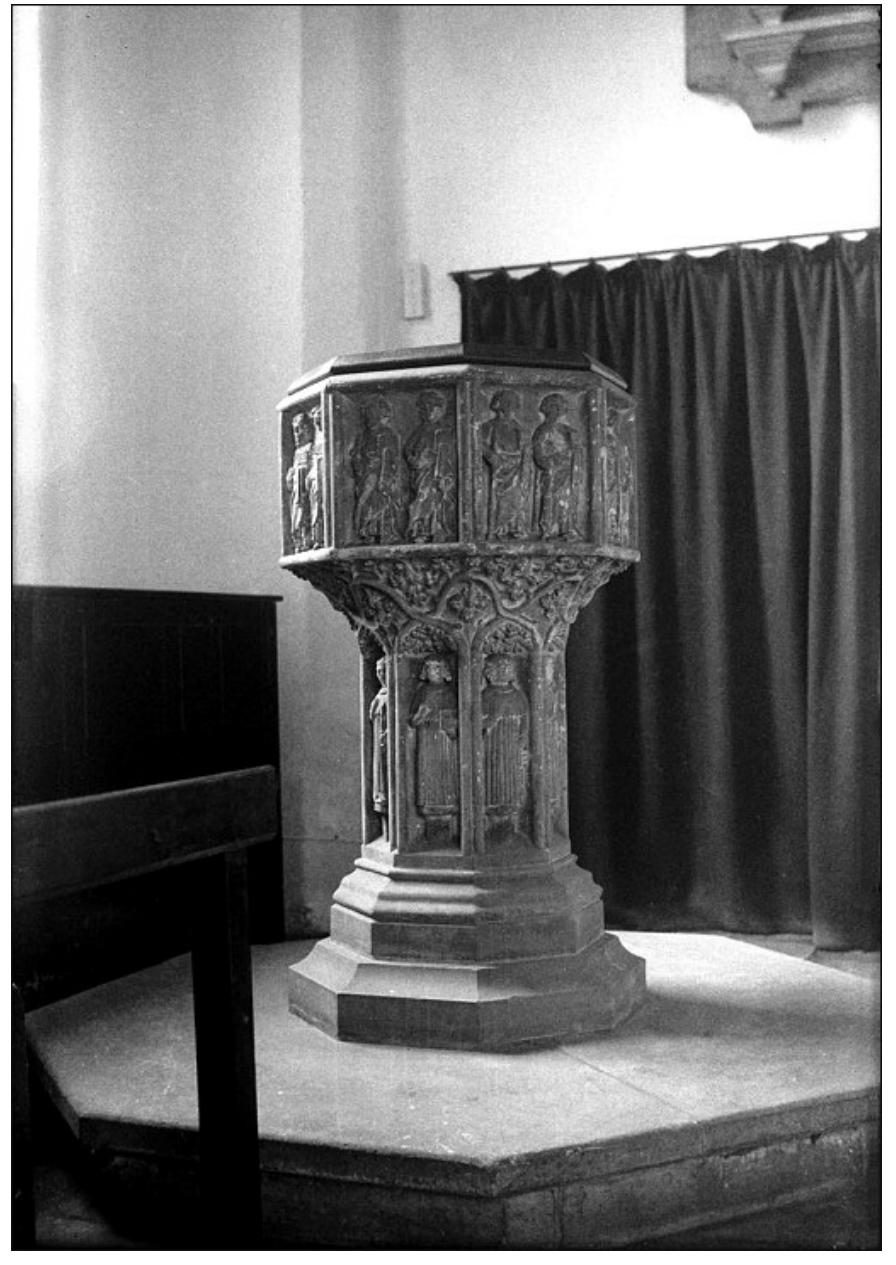

Plate 8: Baptismal Font: Norwich All Saints Westlegate (Photo by: George Plunkett)
(Jarrold and Sons, 1884, p. 76). These carvings, which were added in 1448 following a bequest for emendation, all survived unmolested in sharp contrast to several seven sacrament fonts found across the city to be discussed in the next chapter (Nichols, 2002, p. 182). Further evidence for the enduring nature of this motif can be observed in a nearly identical font surviving in St. James, a parish church serving Cowgate and an annexed hamlet-chapelry called Pockthorpe. This fitting has subsequently been relocated to St. Mary Magdalen on Silver Road where it retains its unscathed decoration. 


\subsection{Screens}

\section{Introduction}

The segregation of space in medieval ecclesiastic structures was central to the clerical and lay understanding of sacrality and authority. This division is clearly demonstrated in the architectural layout of the numerous parish churches scattered throughout Norfolk in the form of rood screens. These elaborate partitions, often comprised of tracery above and painted panels below, depicting a variety of saints, were erected in stone, iron or wood, with the last being the most common in the urban and rural churches of East Anglia. The primary function of this architectural feature was to provide a physical, and conceptual, barrier between the congregational space of the building from the altar space at the eastern end. The origins of this division of space can be traced to the Fourth Council of the Lateran, which gathered in 1215 following a papal bull issued by Innocent III two years earlier. The first canon to be established from the council was an exposition of the Catholic Faith and of the sacraments, which included a brief mention of the doctrine transubstantiation.

There is indeed one universal church of the faithful, outside of which nobody at all is saved, in which Jesus Christ is both priest and sacrifice. His body and blood are truly contained in the sacrament of the altar under the forms of bread and wine, the bread and wine having been changed in substance, by God's power, into his body and blood, so that in order to achieve this mystery of unity we receive from God what he received from us. Nobody can effect this sacrament except a priest who has been properly ordained according to the church's keys, which Jesus Christ himself gave to the apostles and their successors (Leclercq, 1910).

Despite earlier uses of the term 'transubstantiation' in regards to Holy Communion, most notably in the writing of Hildebert, an eleventh century Archbishop of Tours (Hedley, 1907, p. 374; King, 2000, p. 134), the language of the canon is thought to be the first authorized mention of a change in substance during the Eucharistic liturgy. Traditional notions of sacrality were galvanized in response to the miracle taking place 
at the altar; thus endorsing the need for a clear division between the clergy and laity in ecclesiastical architecture.

The custom of partitioning an altar from the rest of a building interior created a sense of divine veneration for the act of sacrifice, which has its origins dating back to the Judaism of antiquity. This notion, combined with the logistics of preparing and administering Holy Communion, required the need to divide the space. Rather than this only being a symbolic segregation of sacrality, it provided seclusion and protection for consecrated personnel to engage in their work.

Rood screens were a visually striking part of the interior architecture of a medieval church; however, they were one part of an elaborate interior design of the crossing between nave and chancel. Firstly, this medieval feature owed its name to the rood, an imposing crucifix statue which was often placed over the entrance to the chancel toward the east end of a parish church. In most cases, images of the Virgin and St John the Beloved, a representation of the Gospel of John 19.25-27, flanked the painted or gilded rood, which had its four arms terminating in either fleurs-de-lys or the symbols of the four evangelists (Alston, 1912). Secondly, ritual and maintenance of the rood required ease of access, which led to the creation of a loft, or gallery, above the screen. From this area, a lighting scheme designed to illuminate the rood could be reached; furthermore, the rood would be veiled for the duration of Lent with either a violet or black cloth adorned with the sign of a white cross (Herbermann, 1907, p. 181). This elevated position also provided an ideal location to address the congregation, for Gospel readings, sermons, or other pastoral services. Thirdly, rood lofts were made accessible by a set of stairs enclosed in the wall separating the chancel from the nave. Finally, the rood often hung from elaborate wrought-iron chains affixed to a transverse beam spanning across the chancel arch. Rather than simply being a plain, and functional, piece of architecture, these carved beams were often richly adorned with gilt.

The ornate partitioning of space was one of the defining architectural features found in all medieval churches across England. Over $80 \%$ of all surviving screens from all four samples are rood screens, which served to divide the space between the chancel and 
nave; a crucial function to facilitate the logistics of liturgy and propagate the sacrality of space. While other screens, such as those installed near a tower, chapel or transept crossing, served important roles, the surviving chancel partitions provide the finest case studies to examine the impact of the Reformation on parish life.

The fragile nature of the physical composition of these screens, polychrome wood, requires alternative criteria for determining if the furnishing should be classified in this study as a medieval survival or a victim of iconography. Furthermore, the sheer size of many of these partitions, especially chancel screens, also requires a more liberal set of standards, as one damaged dado panel out of a dozen should not force the discussion to the following chapter. Screens with less than a quarter of its decoration damaged will be addressed in this chapter, while the absence of the upper portion of the screen will not be assumed a deliberate iconoclasm for our purposes.

The Reformation ushered in a monumental shift in the use of space within a parish church, as the traditional liturgical uses of the chancel were undermined by Protestant theology. While the traditional patronal statues were widely removed and destroyed under the Edwardian regime, medieval rood screens were crucial for the protection of the clergy preparing the sacrament of the Eucharist, which was justified by the supernatural nature of the liturgy as defined by the fourth Lateran Council of 1215. In 1563, the Thirty-Nine Articles of Religion addressed the notion of transubstantiation with its twenty-eighth article by declaring that it "cannot be proved by holy Writ; but is repugnant to the plain words of Scripture, overthroweth the nature of a Sacrament, and hath given occasion to many superstitions" (Bray, 1994, p. 301); (Church of England, 1825, p. 908).

This shift in doctrine resulted in either the removal or modification of existing screens, with often only the lower dado portion remaining. The rate of all surviving screens, including several tower, chapel and crossing screens, across the four samples are .36 screens per church for $R-N W, .35$ for $R-N E, .42$ for $R-S$ and .13 for $U-N$. Out of these survivals, $43 \%$ have been partially dismantled with the upper portion being removed leaving only the dado panels. While the perceived divine nature of the clergy and their liturgical work no longer warranted privacy, the logistics of preparing and administering Holy Communion still required some degree of partitioning. 


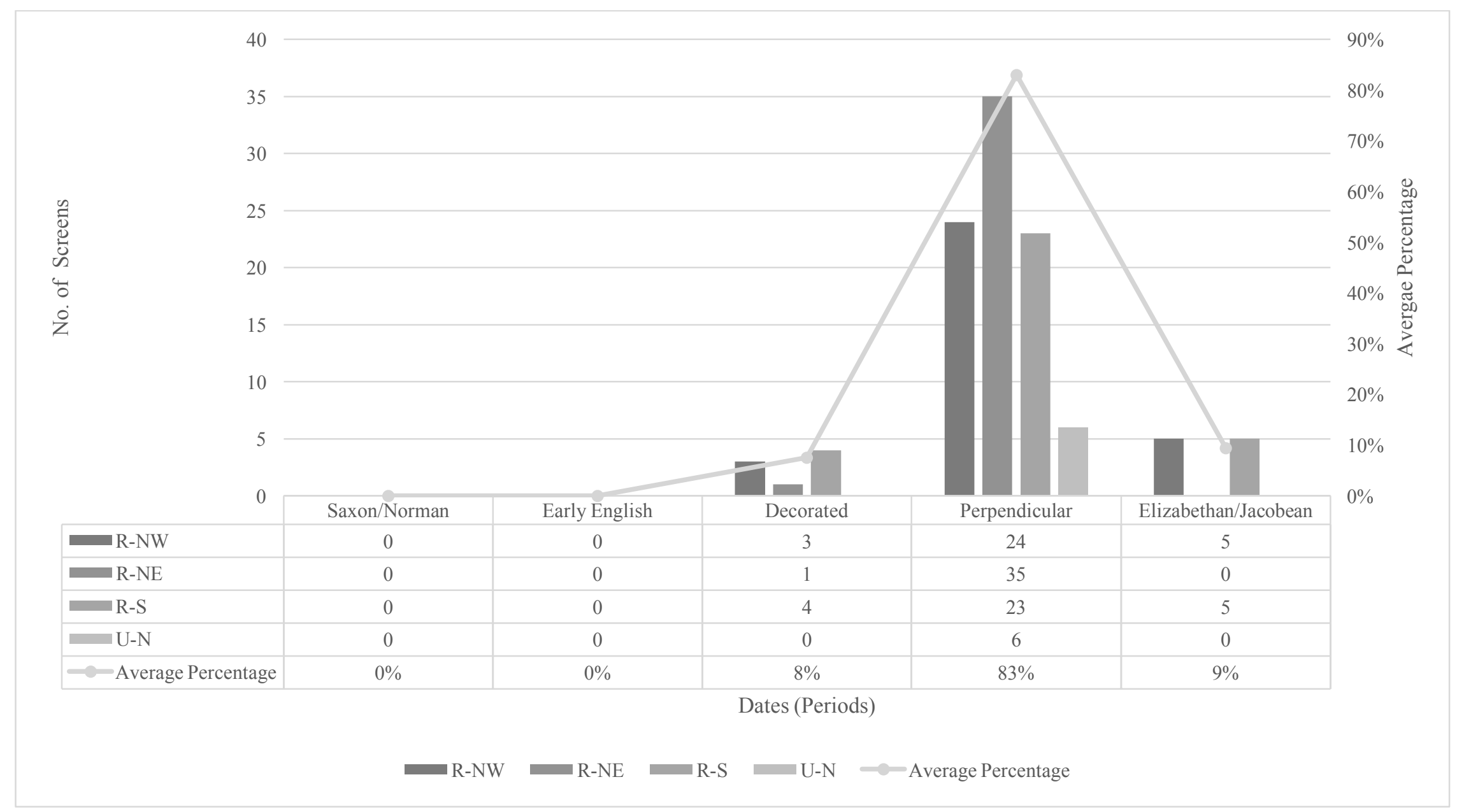

Figure 6: Screens Chronological Distribution 


\begin{tabular}{|c|c|c|c|c|c|}
\hline Sample & & Church & Screens & Percentage & Per Church \\
\hline & & (c) & $(f)$ & $(\% f)$ & $(f / c)$ \\
\hline \multirow[t]{6}{*}{ R-NW } & Brothercross & 10 & 3 & $9 \%$ & 0.30 \\
\hline & Freebridge-Lynn & 36 & 17 & $53 \%$ & 0.47 \\
\hline & North Greenhoe & 21 & 3 & $9 \%$ & 0.14 \\
\hline & Smithdon & 20 & 4 & $13 \%$ & 0.20 \\
\hline & King's Lynn & 3 & 5 & $16 \%$ & 1.67 \\
\hline & TOTAL & 90 & 32 & $100 \%$ & 0.36 \\
\hline \multirow[t]{5}{*}{ R-NE } & Blofield & 19 & 5 & $14 \%$ & 0.26 \\
\hline & South Erpingham & 39 & 13 & $36 \%$ & 0.33 \\
\hline & Taverham & 19 & 5 & $14 \%$ & 0.26 \\
\hline & Tunstead & 26 & 13 & $36 \%$ & 0.50 \\
\hline & TOTAL & 103 & 36 & $100 \%$ & 0.35 \\
\hline \multirow[t]{5}{*}{$\mathbf{R}-\mathbf{S}$} & Depwade & 23 & 14 & $44 \%$ & 0.61 \\
\hline & Diss & 16 & 5 & $16 \%$ & 0.31 \\
\hline & Guiltcross & 14 & 5 & $16 \%$ & 0.36 \\
\hline & Shropham & 23 & 8 & $25 \%$ & 0.35 \\
\hline & TOTAL & 76 & 32 & $100 \%$ & 0.42 \\
\hline $\mathbf{U}-\mathbf{N}$ & Norwich & 45 & 6 & - & 0.13 \\
\hline TOTAL & & 314 & 106 & - & 0.34 \\
\hline
\end{tabular}

Table 8: Screens: Population 


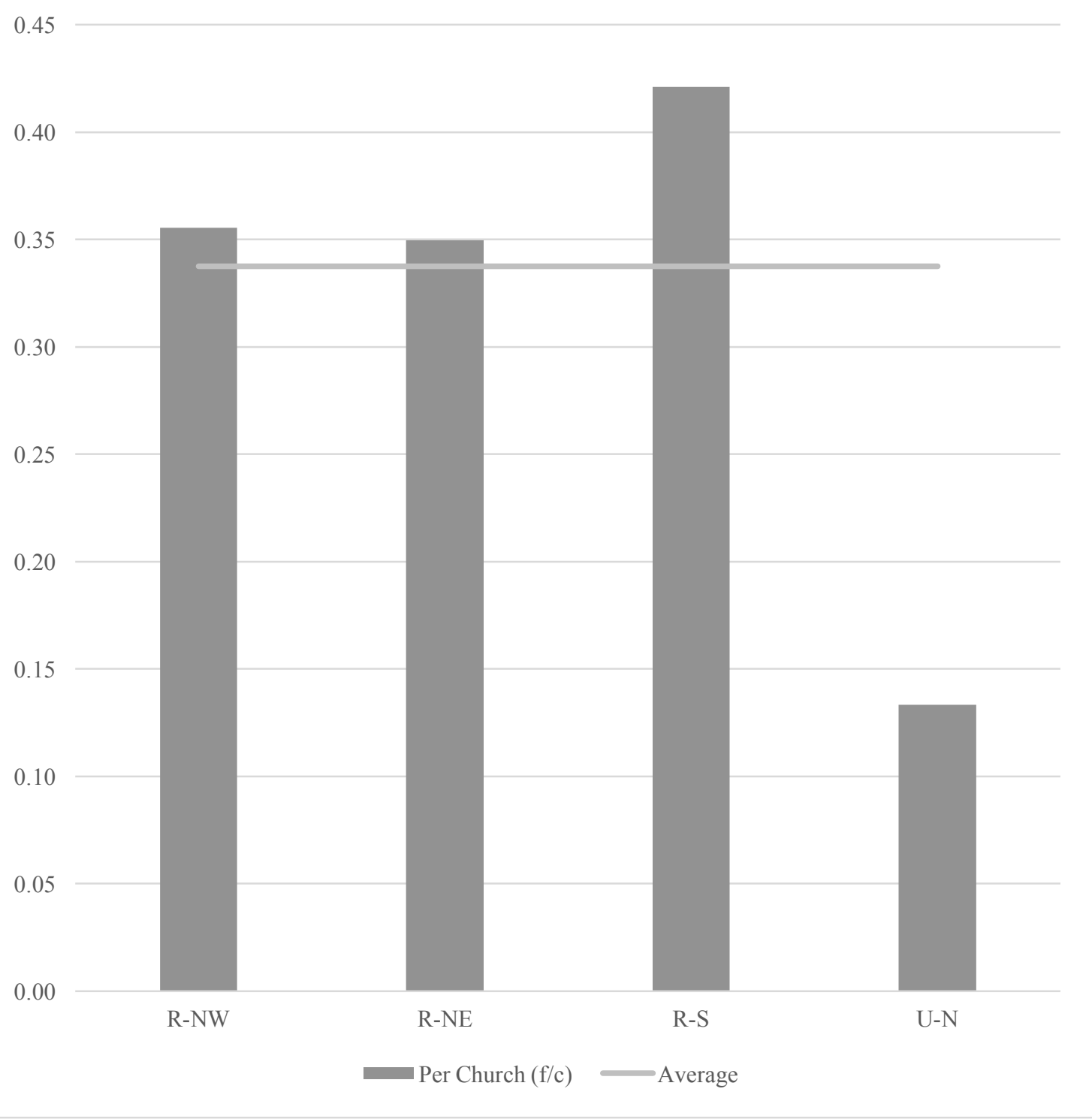

Figure 7: Screens: Per Church 


\begin{tabular}{|c|c|c|c|c|c|c|}
\hline & & R-NW & R-NE & R-S & $\mathbf{U}-\mathbf{N}$ & TOTAL \\
\hline \multirow[t]{3}{*}{ Biblical } & Undamaged & 3 & 10 & 6 & 1 & 20 \\
\hline & Damaged & 6 & 9 & 2 & 1 & 18 \\
\hline & TOTAL & 9 & 19 & 8 & 2 & 38 \\
\hline \multirow[t]{3}{*}{ Extrabiblical } & Undamaged & 1 & 3 & 3 & 2 & 9 \\
\hline & Damaged & 10 & 17 & 5 & 1 & 33 \\
\hline & TOTAL & 11 & 20 & 8 & 3 & 42 \\
\hline \multirow[t]{3}{*}{ Secular } & Undamaged & 2 & 1 & 5 & 0 & 8 \\
\hline & Damaged & 0 & 1 & 0 & 0 & 1 \\
\hline & TOTAL & 2 & 2 & 5 & 0 & 9 \\
\hline \multirow[t]{3}{*}{ Decorative } & Undamaged & 4 & 4 & 9 & 4 & 21 \\
\hline & Damaged & 0 & 1 & 0 & 0 & 1 \\
\hline & TOTAL & 4 & 5 & 9 & 4 & 22 \\
\hline TOTAL & & 26 & 46 & 30 & 9 & 111 \\
\hline
\end{tabular}

Table 9: Screens: Iconography

\section{R-NW Sample}

This section will examine two medieval rood screens located in the parishes of Hunstanton, now known as Old Hunstanton, and Castle Acre, which was previously discussed for its baptismal font and canopy. Hunstanton had sustained aristocratic continuity from the eleventh century, throughout the period of this study and beyond. Along with its fairly isolated location along the northeast coast, this conservative parish was able to operate without much outside or direct interference. Castle Acre was selected for its use of a nearly identical motif to Hunstanton, with slight alterations which may have had nationalistic causality. 


\section{Case Study: Hunstanton}

The village of Hunstanton, located on the northeast coast of Norfolk, presents a case of extended aristocratic continuity, with various incarnations of the le Strange family holding influence over the parish from the Conquest through the Reformation, all the way to the Victorian restorative work and beyond. This family began their influence in the area following their eleventh-century arrival through the marriage of Roland le Strange to the daughter of Ralph, Lord of Hunstanton. This union further bolstered the family's position, as Guy le Strange, father of Roland, was granted lordship in Cheswardine, Shropshire by Alan fitz Flaad, Sheriff of Shropshire and courtier to Henry I. Hunstanton retain a Saxon church consecrated to St. Mary, which was given by John le Strange, son of Roland, to Haughmond Abbey, an Augustinian monastery in Shropshire in 1178. Blomefield (1809, pp. 312-328) points out this undertaking fulfilled an archaic custom where a lord would offer the patronage of his church to a monastic order founded by a greater noble who was responsible for his position; in this case, William FitzAlan, the son of the aforementioned Alan, was the founder of the abbey.

The subsequent centuries saw the fortunes of the family continue to extend their influence throughout Norfolk, apparent through the creation of several modest peerages, including baronies in Knockin and Blackmere. By 1301, John le Strange, the second Baron Strange of Knockin and the sixth descended of Roland, offered his lordship of Hunstanton to his brother, Hamon, in exchange for not having his son's claim to the peerage challenged. As the new master of the parish, Hamon set upon extensive renovations of the church; an undertaking which would be primarily undertaken by his son and completed around 1340 (Blomefield, 1809, pp. 312-328).

The surviving chancel screen found within the church is not dated to this period of construction; rather, it was installed and decorated on the eve of the Reformation around 1505 (Plate 9; Pevsner \& Wilson, 1999, pp. 67, 438). The lower portion of the screen is comprised of twelve panels, each featuring an unmolested representation of the eleven faithful apostles and St. Paul. The style of the painted figures links this screen to the artwork found on another screen in Norfolk, including St. James Pockthorpe in Norwich, subsequently moved to St. Mary Magdalene (Pevsner \& 

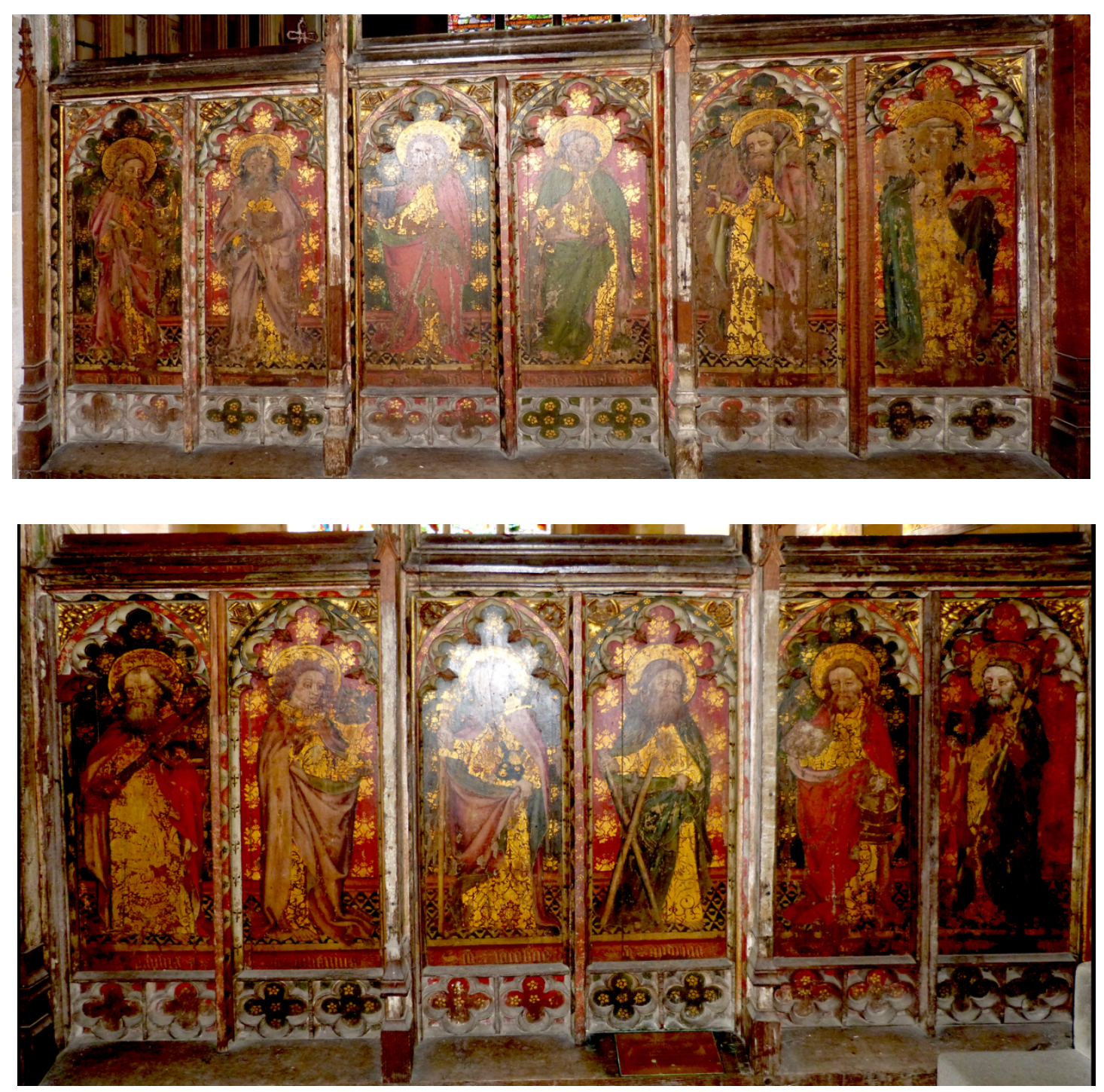

Plate 9: Screen: Hunstanton

North Side (Top); South Side (Bottom); 11 Apostles and St. Paul

Wilson, 1997, p. 330), and in North Elham (Pevsner \& Wilson, 1999, p. 569). This New Testament iconography survives undamaged, having only been removed once during 1857 renovations that saw the upper tracery replaced and set upon the original wooden panels.

The village remained relatively conservative throughout the Reformation, as the le Strange family forged strong ties with Thomas Howard, the third duke of Norfolk. In this period, Nicholas le Strange benefited from his position as Chamberlain to the duke and went on to have a successful career as High Sheriff of Norfolk and a Member of 
Parliament before being granted additional holdings in Gaywood. Catholic connections of this nature continued, as Nicholas' grandson Roger served Maximillian II, the Holy Roman Emperor, before being formally recommended to Elizabeth I. It is possible that this conservative trend extended throughout the entire parish, as the church had been served by five separate religious guilds before their dissolution following 1547 (Blomefield, 1809, p. 328). Despite this dynamic, the churchwardens at St. Mary's in the same period recognized a reforming, or at least compliant, shift in culture as they altered the original record of their chalice and paten to a 'cup' and 'cover' in their inventories compiled during the reign of Edward VI (Walters, 1965, p. 220).

\section{Case Study: Castle Acre}

The conservative parish of Castle Acre and its church consecrated to St James, discussed earlier in this chapter, retains the dado of a medieval rood screen (Plate 10). This fitting presents an interesting analytical challenge, as the vibrancy of the paintwork suggests it was either touched up or restored in more recent times; likely during the Victorian period. In spite of this, the figures depicted on each of the twelve panels do not feature much damage to the wood itself, as acts of vandalism often resulted in traces of gauging. Similar to the screen found at Hunstanton, the motif found here is of the eleven faithful apostles, with St. Matthias, the Apostle appointed to fill the vacancy left by Judas Iscariot (Acts 1.23-26).

Of the twelve images, two retain traces of damage resulting from either vandalism or negligence. Despite being the namesake of the church, the depictions of St. James show signs of damage to the eyes. The nature of Catholic veneration for James, who was also the patron saint of Spain, would have been singularly offensive to proponents of the Reformation, as a pilgrimage to a shrine commemorating his alleged resting place along the Camino de Santiago, or Way of St. James, was one of the most prominent religious expeditions undertaken by Western European Catholics. These pilgrimages were deemed superstitious following the Tudor government: 

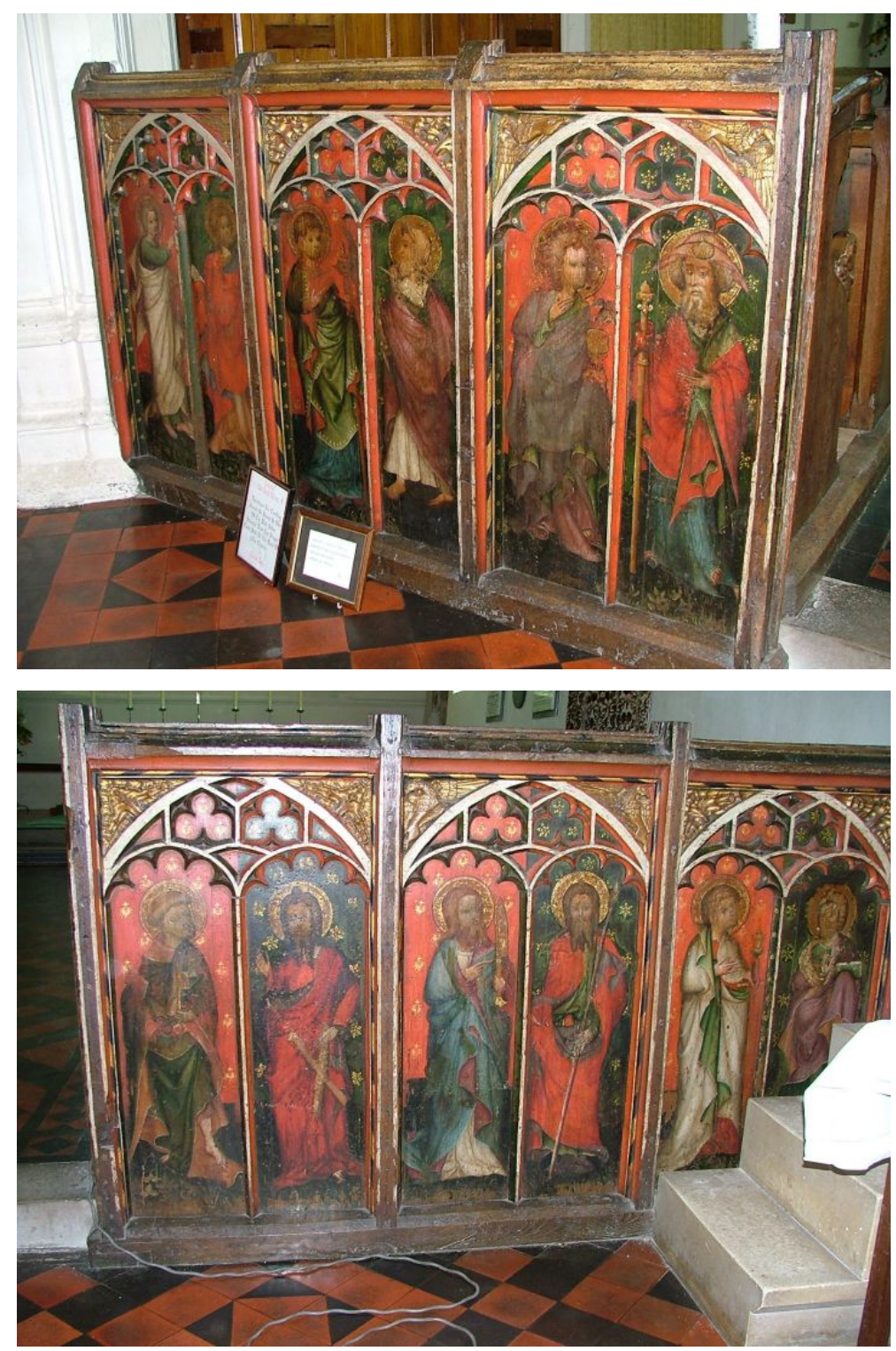

Plate 10: Screen: Castle Acre (Photo by Simon Knott)

Also, that they shall take away, utterly extinct, and destroy all shrines, coverings of shrines, all tables, candlesticks, trindals, and rolls of wax, pictures, paintings, and all other monuments of feigned miracles, pilgrimages, idolatry, and superstition, so that there remain no memory of the same in walls, glass windows, or elsewhere within their churches and houses; preserving nevertheless, or repairing both the walls and glass windows; and they shall exhort all their parishioners to do the like within their several houses (Elizabeth I, Injunction 1559 XXXIII in Gee \& Hardy, 1896, p. 423) 
This offense would no doubt have been compounded in this period by the emerging hostility between England and Spain, exacerbated by both the marriage of Mary I and Spanish ambition to restore Catholicism. It is a testament to this image's strong association with its biblical origin, and not its subsequent medieval trappings that it was spared a more severe mutilation. With only the eyes retaining traces of damage, it is possible that the iconoclast recognized the eyes as a reciprocal gateway that empowered the effigy; perhaps even suggesting that the saint was looking back at you. In the abolition of religious superstition, it is possible that the act of blinding a depiction of your enemy's patron saint was fueled more by superstitious nationalism.

It should also be noted that the panel depicting St. Andrew also bears the traces of some minor damage from gunfire; however, this is most likely a result of a failed attempt to clear the church interior of crows. Infestations of this nature were very common as the roofs of medieval churches fell into disrepair, leading to local parishioners being hired to clear out the building with the blunt use of firearms (Knott, 2005).

\section{R-NE Sample}

This section will examine two medieval rood screens located in the parishes of Edingthorpe and Tunstead. The screen at Edingthorpe was selected for the placement of its biblical motif, which was purposefully arranged with a sense of hierarchical sacrality. The screen at Tunstead was chosen for analysis for not only its inclusion of biblical figures, but its inclusion of extrabiblical images that may have survived as a result of their association with teaching.

\section{Case Study: Edingthorpe}

The small village of Edingthorpe, which saw its parish absorbed into that of Bacton in 1935, retains a round-tower church dedicated to All Saints with part of its construction dated to the Saxon period. Like many examples found throughout Norfolk, control of the parish was shared between the powerful laity and a monastery, in this example a Cistercian abbey in Cumbria. In 1259, a legal conflict emerged over control of All Saints between John de Warenne, sixth earl of Surrey, and John de Sancta Fide, with the former gaining control and restoring a portion of the church to the abbot of Holmcultram Abbey and ensuring a fifth of all income reserved for the king 
(Blomefield, 1810, pp. 27-28). During the reign of Henry VII, the manor was given to William Boleyn, grandfather to the future queen consort, Anne, and remained in his family until the collapse of the Boleyn faction in 1536; Henry VIII inherited the lordship and later offered it to William Woodhouse, a naval commander who played an influential role in the Henrician reconstruction of the navy. While the political and religious inclinations of this parish are difficult to decipher from the written record, the surviving accounts do reveal that Queen Mary I presented a rector alongside her Spanish husband, Philip (Armstrong, 1781, p. 39; Blomefield, 1810, p. 28).

The surviving chancel screen is dated to the fifteenth century (Plate 11; Page \& Doubleday, 1906, p. 542), and features the traces of what was once rood stairs that would have provided access to the loft; similar to the aforementioned Castle Acre (Duffy, 2012, p. 263). This fitting retains its original circular tracery, a style seen at other churches in Norfolk, such as Merton, and six dado panels. The paintwork features ornate depictions of six apostles, with three on the north side and three on the south side. While the figures appear contemporary to the construction of the screen, the white ogee-arched tracery enveloping each image appears to be a later addition, as traces of wear reveal an even earlier flower motif. The north panels feature Bartholomew, Andrew, and Peter with each biblical saint wielding his notable medieval instrument; a fish knife, saltire, and cross keys respectively. The south panel continues the series of biblical saints with St. Paul, St. John and St. James brandishing a sword, an apocalyptic book, and scallop shell, respectively. It should be noted that both Peter and Paul are positioned as the most prominent figures, as they would have been to the left and right of the medieval rood, a sharp contrast to the traditional use of the Virgin and St. John as the flanking figures of prestige. With the exception of the white tracery, which may have been a Victorian innovation, each image show signs of erosion resulting from the passage of time as opposed to deliberate iconoclasm; however, the damage to the strong Catholic portrayal of Peter may have been purposeful. The use of the floral background, a common decoration on Norfolk screens, combined with the clear scriptural context of the iconography, contributed to the survival of this modest partition. 

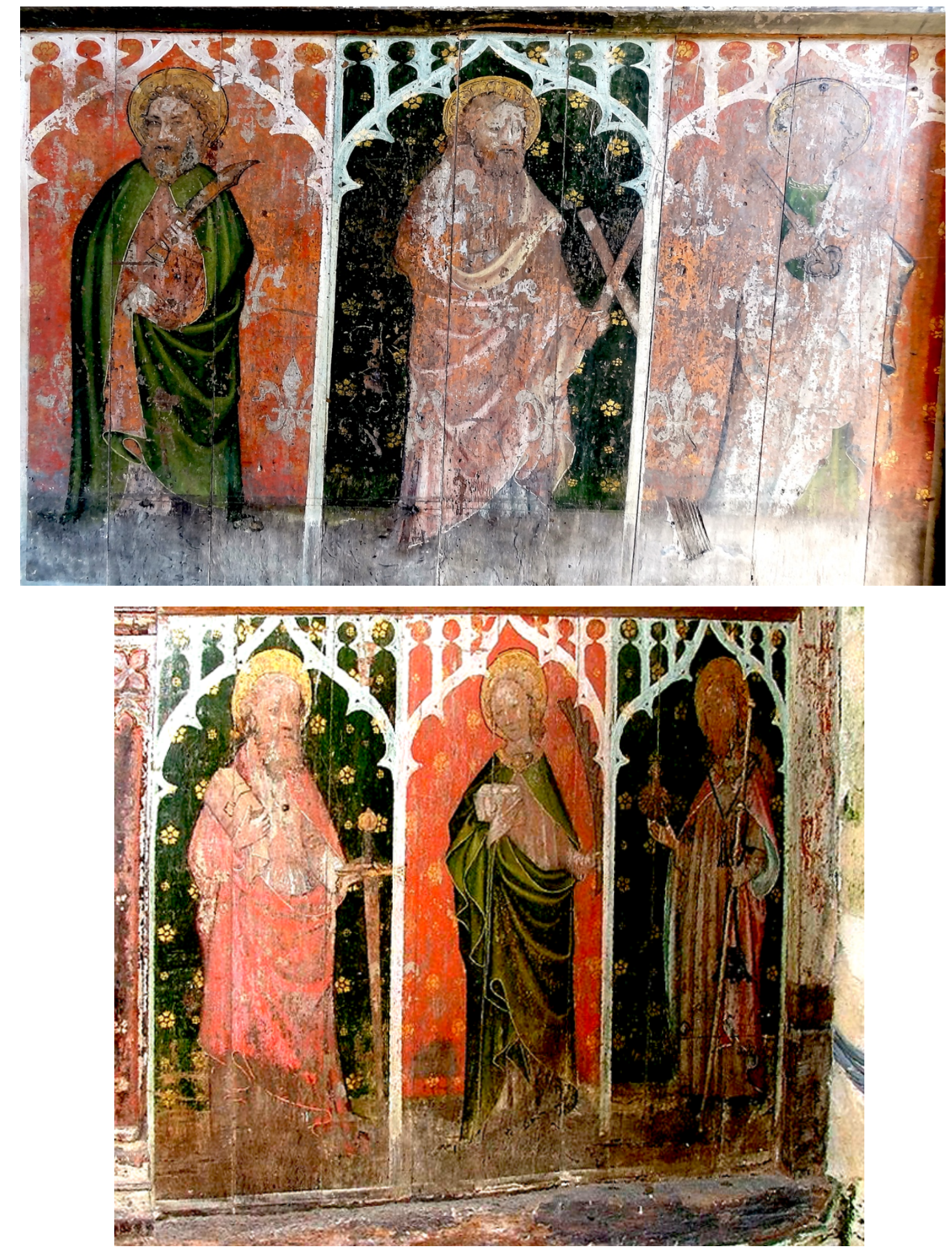

Plate 11: Screen: Edingthorpe

(Photo: Simon Knott) 


\section{Case Study: Tunstead}

The parish of Tunstead can be traced back to a Saxon settlement, which served as the capital for the hundred, the geographic divisions within the county, of the same name. The church, dedicated to St. Mary the Virgin, and its rectory, was a possession of Campsey Ash Priory in Suffolk. By the fourteenth century, the commercial prosperity of the town resulted in plans to construct a new, and grander, church starting with a new nave and square tower. These plans were interrupted by the cataclysmic pandemic of bubonic plague, which struck mercantile hubs like Tunstead the hardest. This period ushered a massive decline in population and fiery demolition of most of the buildings, leaving only the unfinished church as an enduring symbol of the town's former glory. In the aftermath, the lordship was imparted from Sir John Stretch to Henry of Grosmont, which ultimately resulted in Tunstead being made part of the duchy of Lancaster following the ascension of Henry IV. Furthermore, the bishop of Norfolk nominated Henry de Taterford as the parish's first vicar, complete with sufficient income shared with their Augustinian masters in the south (Blomefield, 1810, pp. 7073; Knowles, 1959, p. 290). Construction resumed on the church with the nave being completed in a different architectural style by 1370 .

The Reformation ushered in massive upheavals for Tunstead, as the seizure of the monasteries, resulted in their share, and vicar's patronage, being appropriated to one John Corbet, with an additional portion being held by the Crown. In addition, everyday life in the church underwent extensive changes resulting from the suppression of three religious guilds, two tabernacles with Lady of Pity and Trinity with St Ann, and nine votive candles lit commemorating a litany of saints (Blomefield, 1810, p. 73).

The surviving medieval rood screen, with its open tracery and sixteen dado panels, may have been contemporary to the completion of the nave; however, the sixteen painted figures have been dated between 1470 and 1490 (Plate 12; Pevsner \& Wilson, 1999, p. 702). Like Castle Acre, this screen features the eleven faithful apostles with the addition of St. Mathias. Moreover, the two outer dado panels on each end feature the four Latin Doctors, with St. Gregory and St. Ambrose to the northern end and St. Augustine and St. Jerome to the southern end. Each panel features an ornate ogee arch above the figure, the name of the saint beneath the image and two quatrefoils at the 
bottom. Robert Whiting (2010, p. 187) suggests that the inclusion the aforementioned decorative schemes are tied to the teaching function linked to the position of a screen or a pulpit, while Duffy (1992, p. xxxiii) indicates that the purpose of such images was to reinforce the authority of hierarchy. These two perspectives align with the religious tension of the seventeenth century, with conflicting positions of the role of the Anglican Church in the life of its parishioners ranging from an emphasis on hierarchical respect for order of the Stuarts to the 'godly' preaching and teaching promoted by liberal reformers. The remarkable condition of these panels, devoid of any damage or repainting, suggests that in select instances the Latin Doctor scheme was acceptable, on either the grounds of their association with hierarchy or teaching; however, this screen is the only case where this occurs and this motif shows sign of defacement in every other case found across the samples. 

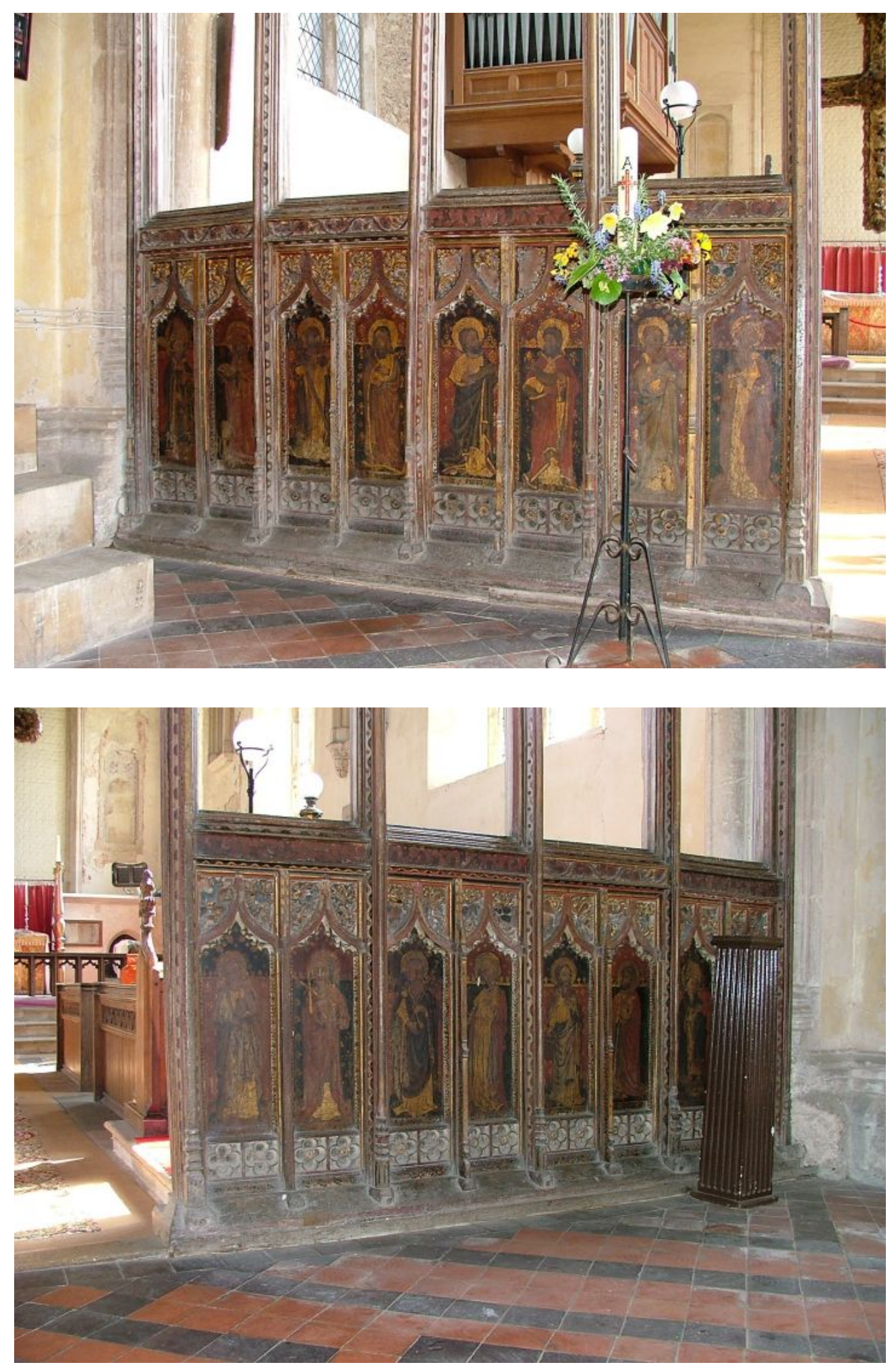

Plate 12: Screen: Tunstead

(Photo: Simon Knott) 


\section{R-S Sample}

The surviving medieval rood screens in the $R-S$ sample group tend to be adorned with neutral decorative schemes, like floral patterns, quatrefoil or heraldry, in place of the more complex effigy iconography. This group is unique in the case of quatrefoil and heraldry, with eight and four survivals respectively; and not one is to be found in the other three samples. Conjecture for image destruction is an issue that will be addressed extensively in the following chapter; however, the work of parliamentarian visitation in the mid-seventeenth century, spreading north from Suffolk, was mostly confined to the southern regions of Norfolk. This could account for a rigid enforcement of restrictions on images by parliamentarian agents, which was often the concern of the locality or the episcopacy to administer throughout the rest of the county.

\section{Case Study: Tivetshall St Margaret}

The village of Tivetshall had the unique arrangement of possessing two churches, less than a mile in distance, as part of the extensive manor that extended into Gissing and Shimpling. The decades preceding the Conquest saw this manor come under the control of Bury St Edmunds Abbey, as Syward, a monk from the Benedictine institution, had his parents cede their interests in exchange for him being made dean of the monastery (Blomefield, 1805, p. 205). In addition to the forty acres of land, the abbey received the mother church of the parish, dedicated to St. Mary the Virgin, and its parochial subordinate, consecrated in the name of St. Margaret. Despite being regarded as a single institution, the churches were treated as distinct parishes with their own rectors and churchwardens.

The monastic suppressions carried out early in the Reformation resulted in the manor passing from Bury to the Crown, before beings granted to Sir John Cornwallis, who served under the duke of Norfolk during Henry VIII's military adventures in northern France before being made the steward of the prince's household, the future Edward VI. In spite of this inherent Protestant inclination, John's son and heir, Thomas, used his position as of sheriff of Norfolk and Suffolk to suppress local opposition to Queen Mary's accession and for a return to Catholicism. This act resulted in not only an appointment as a privy counselor but also a promotion as comptroller of the royal household until the queen's death in 1558. The reign of Elizabeth resulted in Thomas 
being dismissed from office and returning to manage his rural interests, including Brome Hall in Suffolk and Uphall Manor in Tivetshall. Following the fall of the Cornwallis' patron, Thomas Howard, fourth duke of Norfolk, Thomas was placed under house arrest as a 'prisoner for matters of religion' and forced to conform to the Elizabethan settlement. His remaining years saw him as a recusant who was allowed to live with his brother William, a Catholic priest who was previously imprisoned in London, until his death in 1604 (Bindoff, 1982, p. 709). By this time, St. Margaret's had grown to surpass its mother church with over one hundred communicants and a strong sense of autonomy evidenced by their longstanding refusal to acknowledge the authority of their monastic, and later secular, manorial masters while still exhibiting signs of subordination to the diocesan episcopacy alone (Armstrong, 1781, p. 176).

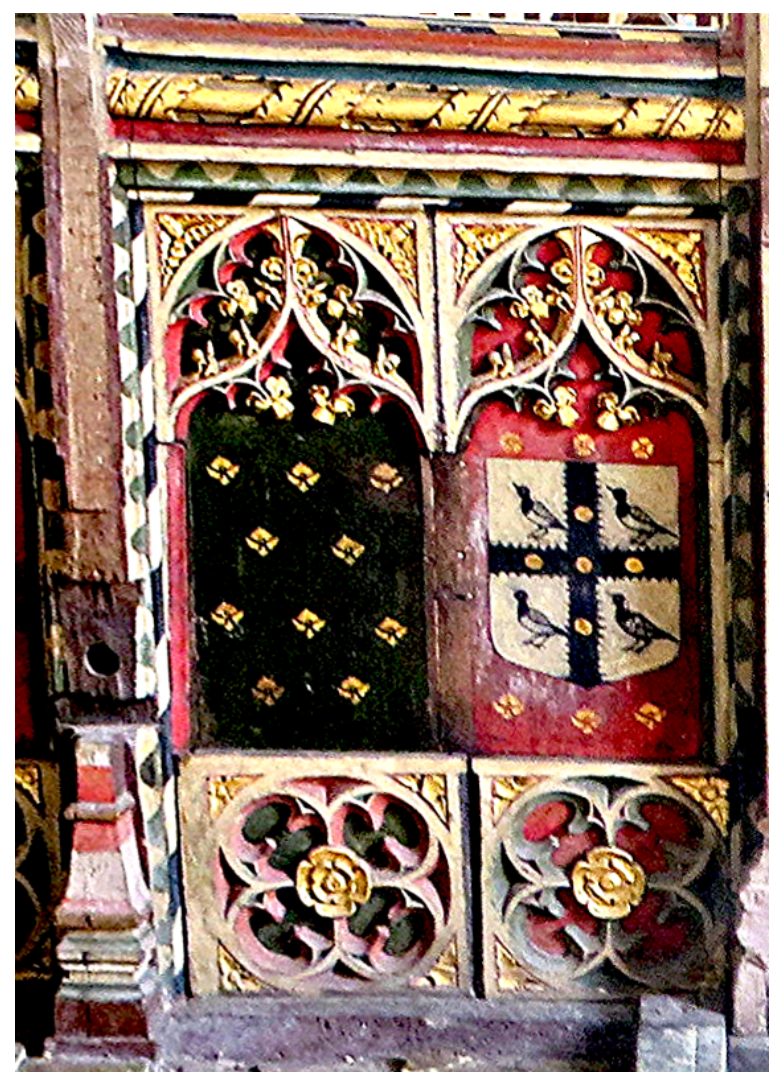

Plate 13: Screen: Tivetshall St. Margaret

The dado of a medieval chancel screen has survived, with the later addition of open tracery and an elaborate late sixteenth-century tympanum commemorating Queen Elizabeth I (Plate 13). These panels retain their original alternating red and green paintwork with gold floral stenciling, and gilded diagonal quatrefoils at each base. Eight of the twelve panels also retain gilded ogee arch tracery, with signs of the four southern panels having been removed. The panel closest the screen opening on the northern side features a heraldic shield, with four birds emblazoned on each corner separated by a cross containing five roundels. In spite of the common identification of the birds as magpies (Blomefield, 1805, pp. 211-212), (Pevsner \& Wilson, 1999, p. 735), the shield actually features either martlets or Cornish choughs (Strype, 1824, p. 2) and is associated with the Aylmer family. Despite a conflicting account placing the location of Aylmer Hall in Tilney (Strype, 1824, p. 2), 
the ancient seat of this minor gentry family was located in Tivetshall, with the building receiving either a renovation or rebuilding in the late sixteenth century. In 1521, John Alymer, the future bishop of London under Elizabeth, was born at his family's manor. The influence of liberal religious inclination in the parish, evidenced by the early use of heraldry on a rood screen as opposed to saintly figures, does acquiesce with the notion that Alymer, once a tutor to Lady Jane Grey who was forced to flee England following the ascension of Mary, and his family helped shape the religious landscape in the parish.

A less likely alternative is that the heraldry is associated with Bury, which also features four martlets emblazoned upon a shield (Berry, 1828, p. 15). While this is not the coat of arms for St Edmunds Abbey, the possibility exists that some connection may be linked between the shield and the parish's monastic landlords.

\section{Case Study: Dickleburgh}

The village of Dickleburgh, which lies near the border with Suffolk, was part of a complex medieval parish that included the neighboring towns of Semere and Langmere. This area was served by a church dedicated to All Saints and was further complicated by portions of parish falling under the jurisdiction of another hundred, Earsham. Following the Norman Conquest, the vast and diverse nature of the parish required a unique arrangement to ensure that all portions received fair representation. The church was administered by a rotating series of rectors who represented the four sections of Dickelburgh: Fouldon, Fields, Langmere, which lies in the Hundred of Earsham, and the Diss portion of Semere. In the century preceding the Reformation, Fouldon and Semere merged in 1429 before later unifying with Fields in 1449 and separating from Langmere 1454, leaving one rectory. This unification resulted in the consolidation and distribution of the annual pensions to monastic lords who held a portion of the rectories, including the priors of Butley and St. Faith and the abbot of Bury. The pension owed to Bury was a result of the manor once belonging to Tivetshall, and the arrangement orchestrated there by the monk, Syward. Before the Conquest, the abbot relinquished control of the manor to the church, which led to the manor being shared between three priests with the advowson and pension remaining 
with Bury, until the Dissolution resulted in it being relinquished to the Crown before being passed around for the next two centuries (Blomefield, 1805, pp. 191-195).

The nobility and landed gentry contributed to a diverse mosaic of religious and secular authorities that influenced this large parish. Like many rural areas across the county, a portion of this influence flowed from the Howard family who had acquired Dickelburgh Hall Manor before the Reformation. This dynamic was temporarily disrupted in 1572 when Queen Elizabeth seized these holdings following the duke of Norfolk's arrest and subsequent execution. The remainder of the century saw the manor rented to various local gentlemen before being returned to the Howard family with the accession of King James I. A piece of the Semere portion belonged to the Bacon family, who were at the center of several progressive legal and ecclesiastical cases in the late fourteenth and early fifteenth centuries. Robert Bacon, who had served as Sheriff of Norfolk and Suffolk in 1370, had his manor seized by the king as a result of an undocumented crime. Following Bacon's death, his widow, Joan, sued the Crown and recovered her late husband's deprived property (Blomefield, 1806, p. 300). This legal victory emboldened her to later challenge the Church for the right to receive communion in her own home as she became infirm with age. In 1414, Richard Courtenay, bishop of Norwich, granted permission for her request, which became a precedent later extended to all of the elderly (Blomefield, 1805, pp. 200-01). The unique elements of Dickelburgh make it an ideal case study for a prominent rural parish, which encompassed various villages and manors across more than one hundred.

The dado of a Perpendicular Gothic (c.1350 - 1520) chancel screen (Bond, 1908, p. 511) survives with extensive and detailed woodwork across all four panels (Plate 14). While the red, green and cream paintwork is a result of a meticulous restoration, the relief carvings predate the Reformation and provide one of the more unusual iconographic depictions found in this study (Pevsner \& Wilson, 1999, p. 297). Each panel features a large central quatrefoil with wide cusping and ornate foliage, with four smaller quatrefoils along the base with roses at the center. The foliage is painted green and does not exhibit any signs of gilding, which is uncommon for the period (Colling, 1851, p. 279). The two inner panels feature additional iconography, with an array of effigies, beasts, and grotesques found within the outer and inner spandrels around the 
central four leaflets. While most descriptions of these features are very general (Pevsner \& Wilson, 1999, p. 297; Mortlock \& Roberts, 2007, p. 79), this study will suggest an intimate connection between these images and medieval European folklore and literature. Several of the carvings are evocative of Reynard, an anthropomorphic red fox found in French, Dutch, English, and German fables. The southern panel features a depiction of the fox dragging a goose by its neck, which was a common motif that presented the deceptive nature of the fox and is reminiscent of the Chaucer Reynardian account of Daun Russell in The Nun's Priest's Tale, where a rooster is seduced and seized by the fox only to escape as he arrogantly opens his mouth to taunt his pursuers (Chaucer, 1915). This notion of hubris extends to another common depiction of Reynard as the 'preaching fox.' This same panel features a figure with the body of a fox with the hooded head of a monk, which resembles a drawing of Reynard found in the margins of the Flemish Utrecht Book of Hours from the fifteenth century (Linley, 2016, p. 261). Another carving is of a monk, holding two birds to his left and right, is positioned in the identical position as the 'preaching fox' motif found carved onto a misericord at Ripon Cathedral, Wells Cathedral, and St. Botolph in Boston (Wildridge, 1899, p. 198; Block \& Varty, 2000, pp. 142-143). The medieval Church utilized the fox iconography as a moral defense against heretical teachings, such as Lollardy; just as the fox could seduce the birds with its words, heretical doctrines would consume the souls lured in by preaching (Benton, 1997, p. 83).

The rest of the carvings feature additional imagery linked to medieval animal sagas, including a feline representation, which could be Tybalt, the Cat, a rival of Reynard (Chaucer, 1915). A strong hunting motif is also present, complete with traditional hare coursing, although this carving could represent Reynard's murder of Kayward the Hare and implication of Bellin the Ram. The inclusion of various angels, heads and even a dragon add to the mystique of this screen, as it deviates from the traditional use of religious iconography and offers a glimpse to an alternative social imperative derived from literature. The final feature worth mentioning from this screen is carved effigy of a monk playing pipes with his habit blown back in the upper left corner of the northern inner panel (Mortlock \& Roberts, 2007, p. 79). It is possible this depiction is of Dicul, the parish's namesake, who may be the same man mentioned by Bede as a Scoto-Irish 
monk who had a small monastery in West Sussex, or Dicuil, the post-Bede ninth century monk and astronomer. (Workman, 1916, p. 69; Sawyer, 1883, p. 114).
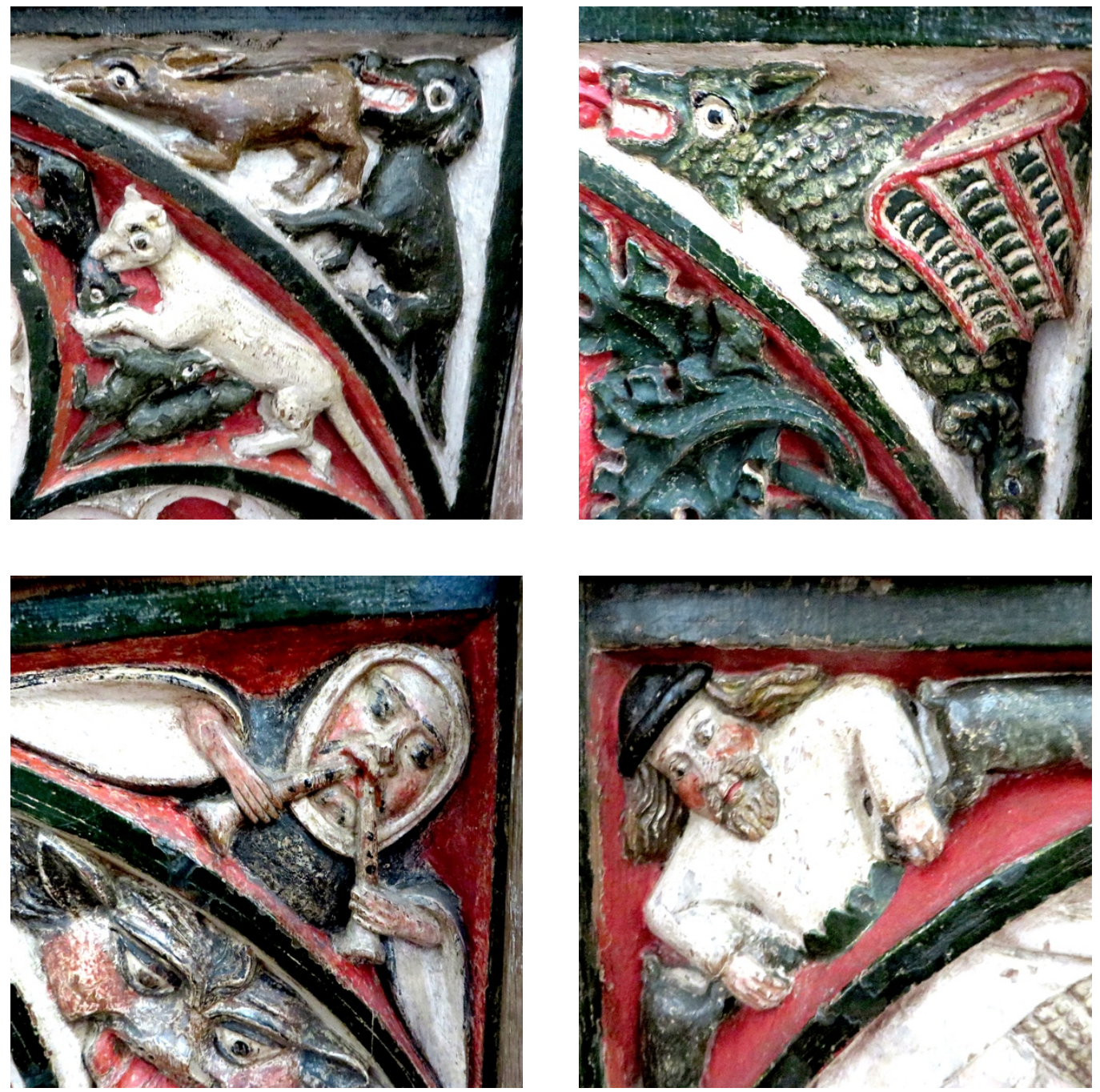

Plate 14: Screen: Dickleburgh 


\section{U-N Sample}

Norwich presents a sharp contrast from the rural samples, as only six medieval rood screens remain: one is a nineteenth century transplant from the parish of Horstead. This suggests that less than a tenth of the screens that stood on the eve of the Reformation in 1520 survived the ensuing transformation of space within the parish churches. The scant evidence does offer a single case that is contrary to the overall tendencies and findings related to surviving iconography throughout the county. While these findings are worth exploring in the following chapter, the marginal and anecdotal nature of their survival does not provide a significant impact on overall trends seen in Norfolk.

\section{Case Study: Norwich: St James at St. Mary Magdalene}

The parish church of St. James with Pockthorpe was founded as part of the city's reorganization following the eleventh century Conquest and began as part of the manor at Thorpe until the first decade of the thirteenth century when the bishop of Norwich, John de Gray, granted the appropriation of the rectory to the Cathedral Priory (Anonymous, 1768, pp. 581-582). As a wealthy parish, with powerful ties and a strategic location near the northern gate, St. James commissioned a new rood screen in 1505 to be painted by the same artist who depicted the apostles on the screen at Hunstanton discussed earlier in this chapter (Plate 15). Rather than maintain an apostolic motif, the ten dado panels illustrate exclusively post-biblical saints, including from north to south: St. Barbara, St. Sitha, St. Agnes, St. William of Norwich, St. Joan de Valois, St. Martin, St. Blaise, St. Walstan, St. Helen and St. Nicholas (Pevsner \& Wilson, 1997, p. 330). The selection of this type of iconography, ranging from famous and local saints to more obscure inclusions, is a unique survival for Norfolk. The panels do exhibit signs of rehabilitation consistent with nineteenth-century restorative work; however, the wooden surfaces do not show any traces of earlier damage. One noticeable sign of wear is the fading on the name inscription beneath each figure, which is especially apparent on the panel featuring William (Monmouth, et al., 1896, p. xxxvii).

In 1946, St. James dispersed many of its medieval furnishings, most notably its baptismal font and rood screen which were installed at its daughter church of St. Mary 
Magdalene on Silver Street, before being closed and converted into a puppet theater in 1980.
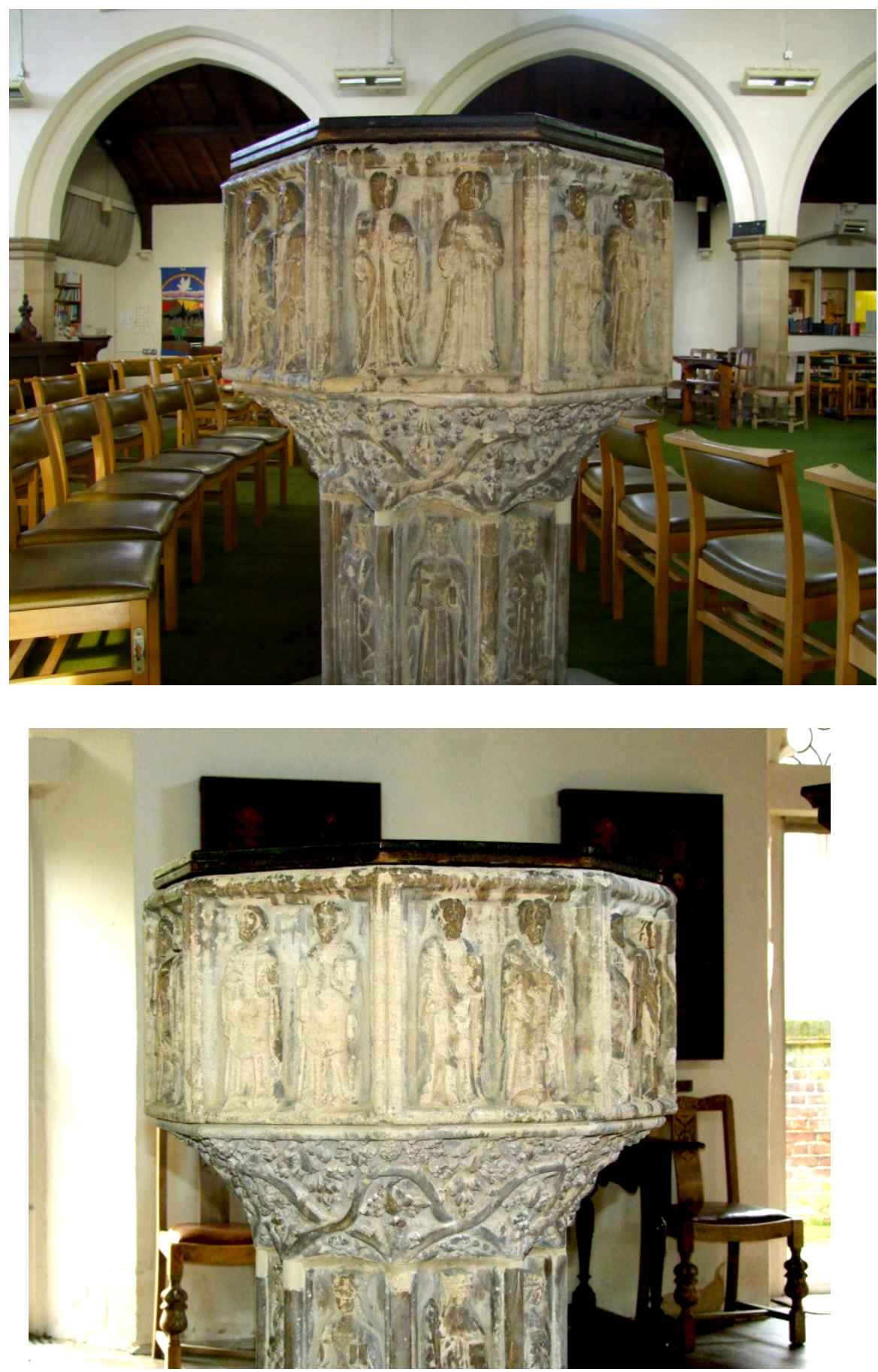

Plate 15: Screen: Norwich St James at St. Mary Magdalene

(Photo: Simon Knott) 


\section{Case Study: Norwich: St Peter Parmentergate}

The parish church of St Peter Parmentergate, located on the northern end of Ber Street, had a strategic location in Norwich with close proximity to St. Peter Mancroft, St. Andrews, the Castle and the Cathedral. With the episcopal see as its patron, and an economic arrangement with the city infirmarer, the church was rebuilt in 1486 to accommodate its growing population, as the rectory nearly doubled in value in the two centuries leading up to the Reformation (Finch, 2004, p. 70; Tanner, 1984, p. 177). The completion of the project required new furnishings by the start of the sixteenthcentury, which included a new chancel screen featuring twelve dado panels (Plate 16). The northern six panels have survived, stripped of any traces of polychrome, and retain elaborately carved ogee arches with ornate floral designs within each spandrel with fleur-de-lis trim across the entire upper edge. One of the panel features a carved relief of St. Michael the archangel in the right spandrel and the dragon in the left, a common late medieval motif popularized in the period by the famous woodcut produced by the German artist Albrecht Dürer (Durant, 1957, p. 311). The figure is easily identifiable from its wings, feathered armor, sword and cruciform shield, which is often interchangeable with an inscription featuring the Latin phrase quis ut deus, which is translation of name Michael which means 'who is like God'. The base of these six panels all features a carved quatrefoil, with the four southern panels utilizing a diagonal variation.

St. Michael iconography shared many similarities to depictions of St. George, the patron saint of England, both of whom emerge in late medieval Christianity as the scions of chivalry, in their artistic depictions and association with religious, military orders (Ball, 2003, p. 586). In spite of this, the literary basis for common artistic interpretations emerged from very different sources. While the tale of St. George slaying the dragon sprang forth in the thirteenth-century writing of Vincent of Beauvais and Jacobus de Voragine, the account of St. Michael battling Satan as the dragon is extrapolated from apocalyptic texts from the New Testament (Revelations 12.7-9; Jude 1.9). The use and endurance of this iconography is a rare case of a metaphysical, rather than historical, representation being an acceptable motif as a result of its connection to the Bible. The use of images of the Book of Revelation will be explored in greater 
detail later in the chapter during an analysis of a collection of roof bosses found in the cloister at Norwich Cathedral.

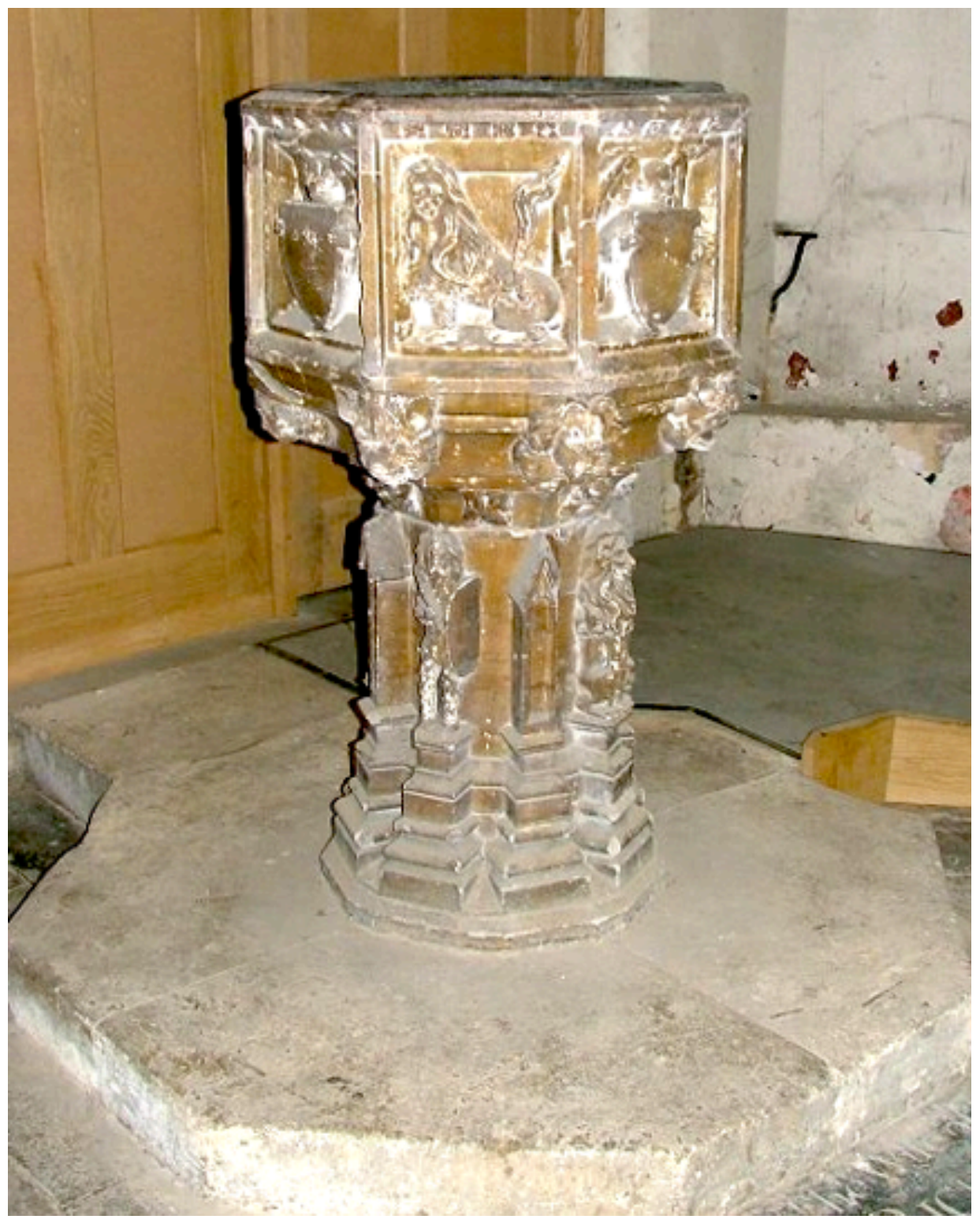

Plate 16: Screen: Norwich St Peter Parmentergate 


\subsection{Paintings - Wall \& Ceiling}

Medieval wall paintings are among the more challenging features of a parish church to classify within the context of this study, as the structural necessity of the canvas usually prevented any attempt at overt demolition. The ensuing whitewashing, or covering with a white lime-based paint, resulted in a paradoxical assault on these instances of iconography that simultaneously expunged the offensive visuals while ironically preserving them to be uncovered by later generations. The assumption that the interior walls of nearly every parish church were covered, in order to remain in compliance with Reformation legislation, does not usually provide enough information within the context of this study to draw any definite conclusions regarding the nature of destruction. While a few exceptions to this will be examined, notably at Norwich Cathedral, this section on wall paintings will instead focus on the shared themes presented in the 65 survivals.

Wall paintings were a distinctive form of artistic expression found in churches across England; simultaneously providing basic interior aesthetic and larger-than-life canvases to promote religious iconography. Norfolk retains more surviving cases of these medieval murals than any other county in the country (Pevsner \& Wilson, 1997, p. 67), with 62 cases across all four samples with a comparable rate of survival within all three rural groups predating the start of the Reformation.

The spartan stone interiors left behind in the wake of the Reformation were once a brilliant and vivid spectacle, which no doubt would have dazzled the senses of most parishioners, who were unaccustomed to seeing such a splendid array of colorful images depicted on such a large scale. The subject matter of paintings uncovered across Norfolk is not dissimilar from survivals found across England, with biblical and extrabiblical content utilized without distinction (Rosewell, 2008). Common extrabiblical iconography include the Blessed Virgin, St. Christopher and St. George, the Seven Deadly Sins and Seven Corporal Works of Mercy and the Three Dead Kings; while images pulled from the Old and New Testament usually focused on the Passion and the apocalyptic Doom, or Last Judgement 
Unlike the previous two fittings, wall paintings provide a very different set of challenges in terms of easily identifying signs of iconoclasm. The relative portability of fonts, and to a lesser extent screens, allowed for their removal or modification The sheer size of these murals, and structural importance of the canvas, required an alternative method to purge any offending content matter, as mounting a scaffold to target the faces of a figure would not be enough. As a result, the survivals cannot be treated as a barometer for acceptability of iconography; however, the paintings do still provide context for the religious mood in Norfolk on the eve of Reformation.

Throughout the period, these visual treasures were not as simple to deface as more portable icons; however, the suppression of these images proved to be far more effective than any sort of destruction. Many parish churches had their entire interiors whitewashed, with the dual purpose of concealing offensive, or illegal, images while offering a bright and modest space which would be more conducive for a 'Word-based' faith. If anything could be authorized to grace these new blank walls, it would be vernacular text from scripture; such remains can be seen at Great Walsingham and Thornham. Over sixty wall paintings, either full images or scant traces, have been uncovered across the four samples groups, with nearly half of these within the $R-N E$ sample.

partitioning. 


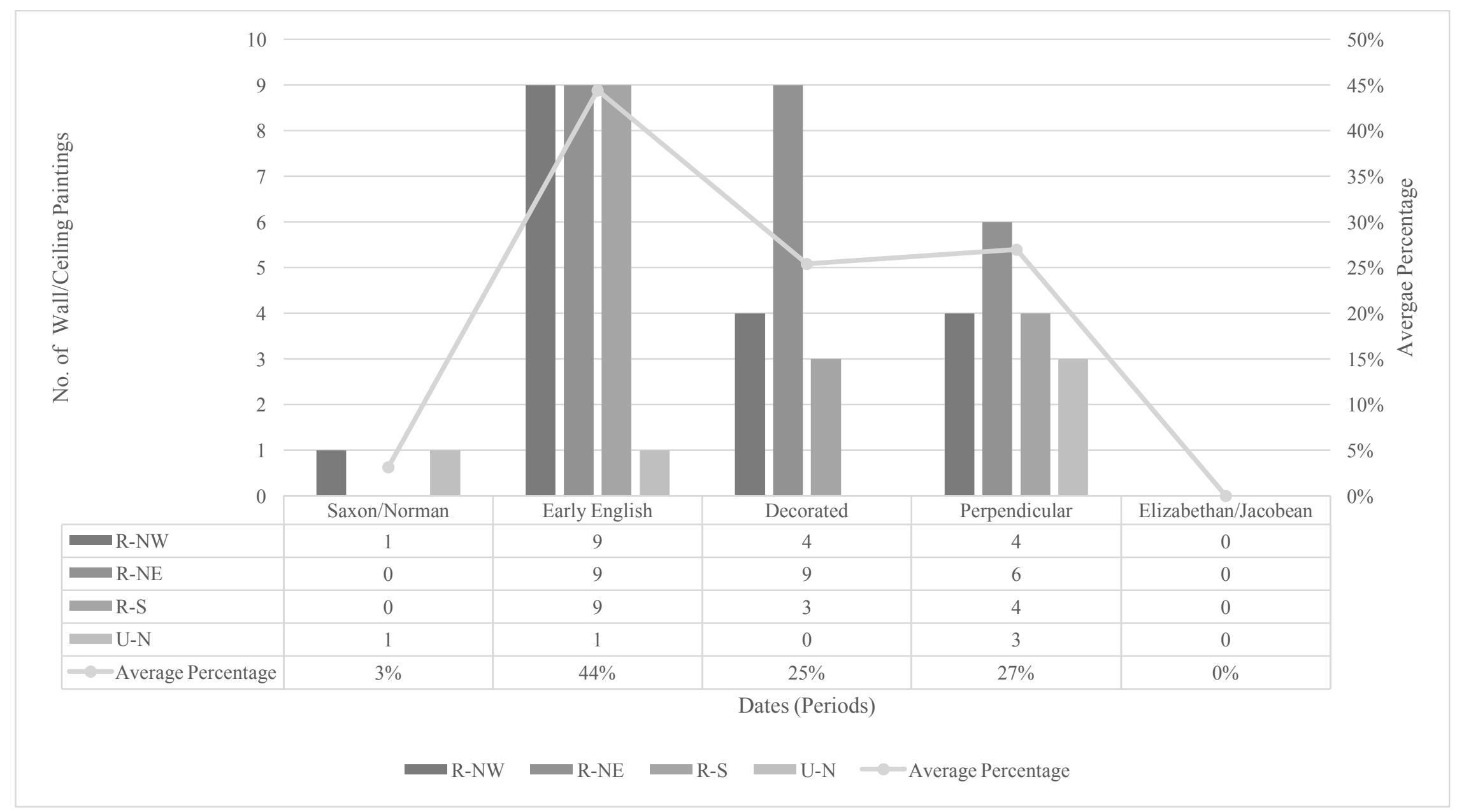

Figure 8: Paintings - Wall/Ceiling Chronological Distribution 


\begin{tabular}{|c|c|c|c|c|c|}
\hline Sample & & Church & Paintings & Percentage & Per Church \\
\hline & & (n) & $(f)$ & $(\% f)$ & $(f / n)$ \\
\hline \multirow[t]{6}{*}{ R-NW } & Brothercross & 10 & 4 & $22 \%$ & 0.40 \\
\hline & Freebridge-Lynn & 36 & 3 & $17 \%$ & 0.08 \\
\hline & North Greenhoe & 21 & 2 & $11 \%$ & 0.10 \\
\hline & Smithdon & 20 & 9 & $50 \%$ & 0.45 \\
\hline & King's Lynn & 3 & 0 & $0 \%$ & 0.00 \\
\hline & TOTAL & 90 & 18 & $100 \%$ & 0.20 \\
\hline \multirow[t]{5}{*}{ R-NE } & Blofield & 19 & 3 & $13 \%$ & 0.16 \\
\hline & South Erpingham & 39 & 7 & $29 \%$ & 0.18 \\
\hline & Taverham & 19 & 4 & $17 \%$ & 0.21 \\
\hline & Tunstead & 26 & 10 & $42 \%$ & 0.38 \\
\hline & TOTAL & 103 & 24 & $100 \%$ & 0.23 \\
\hline \multirow[t]{5}{*}{$\mathbf{R}-\mathbf{S}$} & Depwade & 23 & 5 & $31 \%$ & 0.22 \\
\hline & Diss & 16 & 2 & $13 \%$ & 0.13 \\
\hline & Guiltcross & 14 & 2 & $13 \%$ & 0.14 \\
\hline & Shropham & 23 & 7 & $44 \%$ & 0.30 \\
\hline & TOTAL & 76 & 16 & $100 \%$ & 0.21 \\
\hline $\mathbf{U}-\mathbf{N}$ & Norwich & 45 & 5 & - & 0.11 \\
\hline TOTAL & & 314 & 63 & - & 0.20 \\
\hline
\end{tabular}

Table 10: Paintings - Wall/Ceiling: Population 


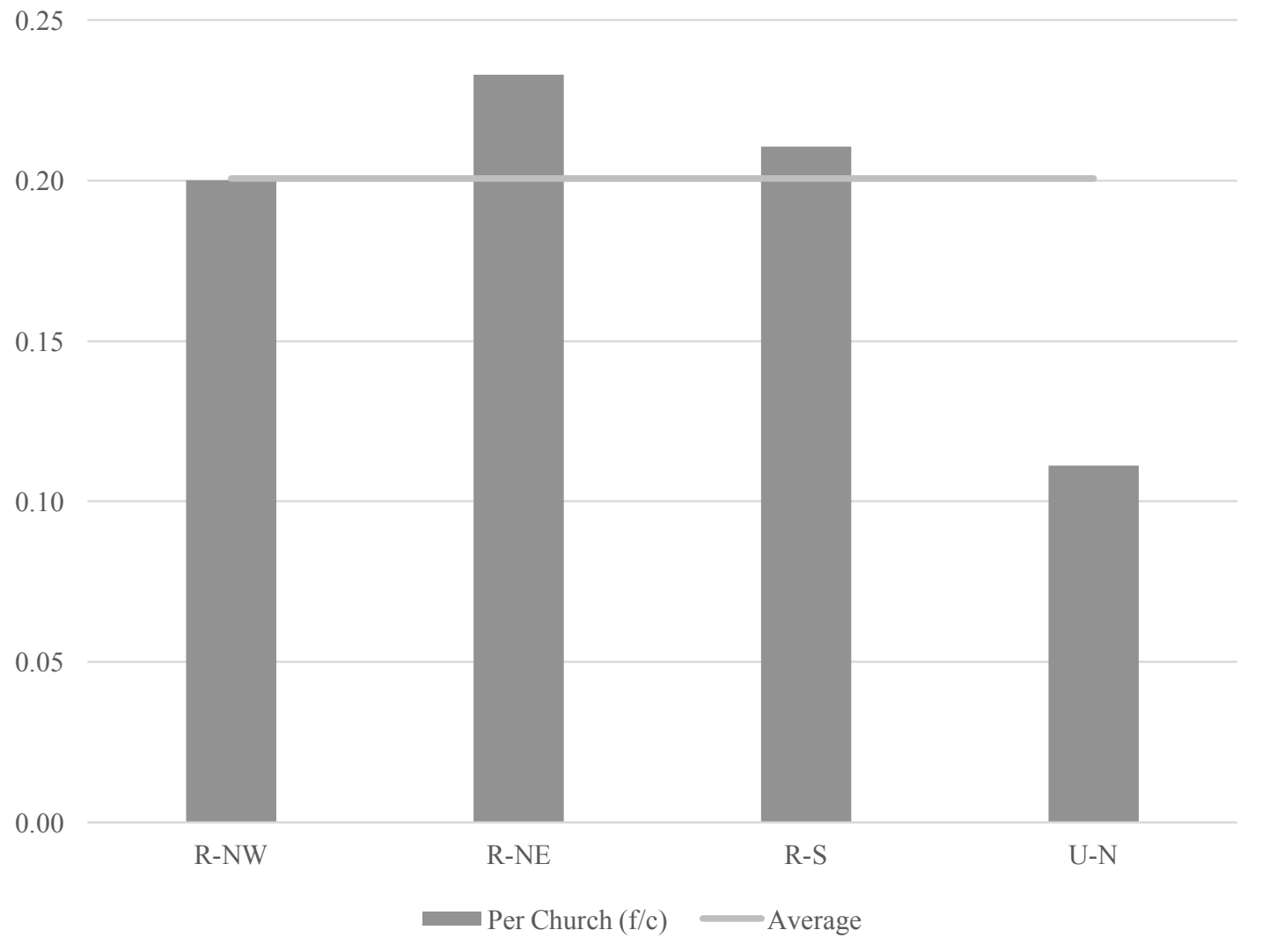

Figure 9: Paintings - Wall/Ceiling: Per Church

\begin{tabular}{|l|r|r|r|r|}
\hline & R-NW & R-NE & R-S & U-N \\
\hline Annunciation & 1 & 0 & 2 & 0 \\
\hline Doom - Last Judgement & 1 & 2 & 1 & 0 \\
\hline St. Christopher & 4 & 11 & 5 & 0 \\
\hline Warning to Gossips & 0 & 1 & 0 & 0 \\
\hline Tree of Seven Deadly Sins & 0 & 1 & 0 & 0 \\
\hline Three Quick \& Three Dead & 0 & 2 & 0 & 0 \\
\hline & & & & 1 \\
\hline Masonry Pattern & 1 & 1 & 0 & \\
\hline
\end{tabular}

Table 11: Paintings - Wall/Ceiling: Iconography 


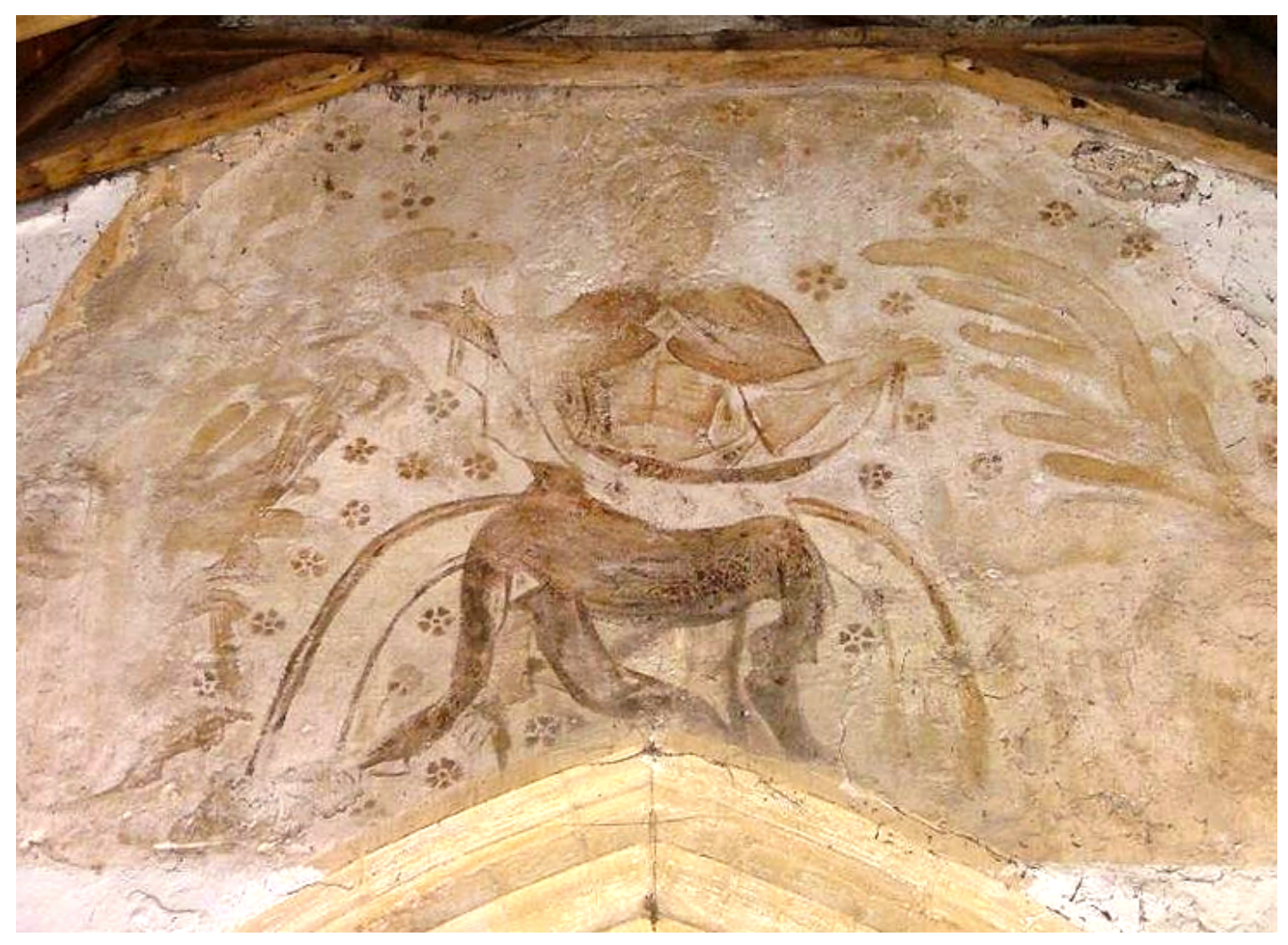

Plate 17: Wall Painting: North Creake- Last Judgement

\section{(Photo: Simon Knott)}

\section{Last Judgement}

The medieval fixation with death, a natural result of the devastating pandemics of the fourteenth century and beyond, saw the role of religion that provided meaning and purpose become more important than ever before. Furthermore, the apocalyptic nature of the desolation could be explained in a Biblical context that served as a sobering call to begin living a righteous life to avoid a final judgment resulting in eternal damnation. The resulting macabre iconography, dealing with life after death, provided a constant and terrifying reminder to parishioners of the importance of their faith and the Church that facilitated its practice. While the point is outside of the realm of this study, it could even be argued that this monopoly on salvation and fear of death after the Black Death culminated in the abuses and excesses of the Church, like the selling of indulgences, that fueled the Reformation on the continent.

While a majority of medieval iconography focuses on the past, through the veneration of saints or moments in history, some images instead look forward towards the Last 
Judgement, as depicted across scripture. These 'Doom' motifs were a useful visual device to illustrate the consequences for not conforming to the tenets of the Church; a very powerful message that was usually positioned on either the east wall, like Bradfield and North Creake (Plate 17), or west wall to influence parishioners either during the Mass or as they were exiting (although cases like East Harling feature this image along the north aisle).

The basic composition of this eschatological motif, including the four examples found in this study, include Christ at the top of the image, flanked by his mother and St. John the Beloved. His outstretched hands indicate that the saved are welcomed to Heaven to his right; while the damned are committed to Hell on his left. As a host of angels blow their trumpets, Michael, the archangel, serves as the facilitator who operates the scale which weighs the sins of the soul. While demons, representing sin, attempt to tip the soul in their favor, some depictions feature the Virgin interceding to counterweight the scale.

Another common usage for wall painting was to create the illusion of depth and texture through usage of patterns that replicated masonry patterns, such as brickwork. The interior walls of churches were often covered with a smooth plaster; that while providing an ideal medium for grand works of art, did suppress the impressive stonework hiding beneath (Rosewell, 2008, p. 15). In areas where an iconographic mural was not possible, simple repetitive patterns, which did not require the rare skill of an artist, provided a method to ensure nearly all wall space would be covered with color and design. Across the four samples, the only surviving examples of this appear at Sedgeford, Burlingham St Edmund, and Norwich Cathedral.

\section{Case Study: Heydon and Paston - Three Dead Kings}

Wall paintings provided the opportunity to present more complex motifs that would otherwise be unsuitable for a panel painting. Intricate and detailed stories, such as the Last Judgement, benefited from being able to depict the host of figures required to convey the story effectively. Another elaborate illustration, found in two instances in the $R$-NE sample, is based on the fifteenth-century Middle English poem, De Tribus Regibus Mortuis (Three Dead Kings). The poem, and the legend it is inspired by, 
features three kings separated from their retainers in the midst of a boar hunt. Soon thereafter, the monarchs are terrified when they encounter three reanimated corpses, and debated whether to flee from the horror or face it with chivalry. The walking dead soon explain they are not demonic entities; instead, they are their ancestors who have appeared to denigrate their heirs for not saying the requisite masses for their souls. They explain that their sinful and materialistic nature, while they were alive, have resulted in being caught in the current dreadful transience between life and death. The nightmarish episode soon ends, and the three kings return home and raise a chantry for their ancestors and have their episode recounted visually on its walls (Plate 18).

Unlike the Doom scheme discussed previously, this legend promotes a theological sentiment that exists in direct opposition with the Reformation in two distinct ways. First, as the doctrine of purgatory, and the coinciding prayer for the dead, lost its essential mandate with the Ten Articles of 1536 was and then declared "repugnant' for its inconsistency with the Bible in the 1563 Thirty-nine Articles. Secondly, the story itself places the royal prerogative as subjected to the authority of the Church, as not one of kings in the story were exempt the consequences and penance for a sinful life (Kinch, 2008, p. 53).

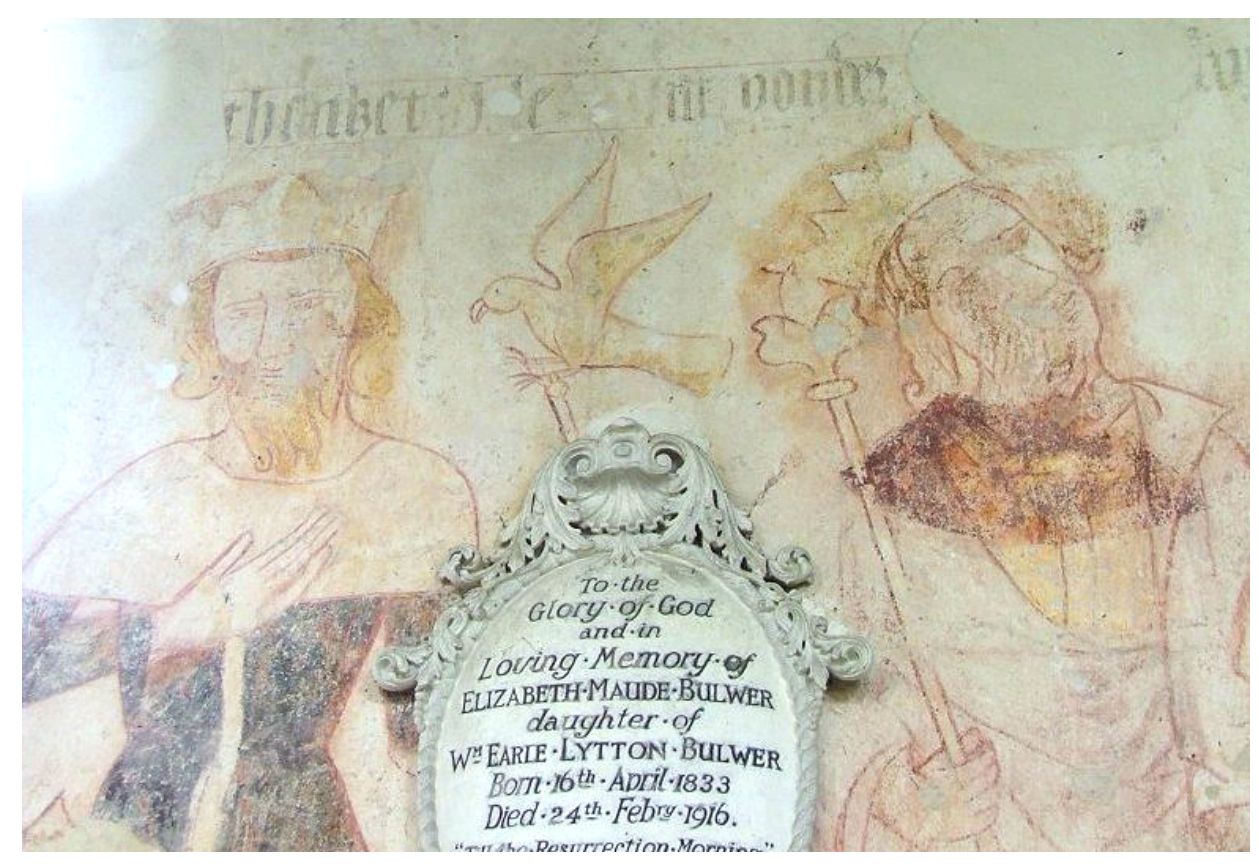

Plate 18: Wall Painting: Heydon and Paston - Three Dead Kings 


\section{Masonry Patterns}

Medieval polychromy was not only confined to the realm of religious iconography, as it often provided an inexpensive alternative for the addition of an architectural decorative scheme. The most common example, which can still be seen at Burlingham St Edmund and Sedgeford, is a simple masonry pattern designed to simulate the appearance of stonework. The interior walls of many early churches were covered with a thin layer of plaster comprised of lime and sand until the more durable and costly gypsum came from the continent in the mid-thirteenth century and slowly emerged as the preferred material (Sharpe, 2011, pp. 99-100). These smooth veneers hid the stonework beneath, providing a blank canvas for all nature of decoration; however, in some cases the aesthetic appeal of the concealed stonework called for its polychrome recreation.

Norwich Cathedral contains traces of this in the ambulatory and chapels near the chancel. For instance, the Jesus Chapel, located off the northern side of the ambulatory, contains a painted pattern which transformed the groin vaults into rib vaults.

Furthermore, the ceiling has been adorned with a pattern which imitates the appearance of bricks. Pevsner (1999, p. 207) speculates that the aesthetic additions could have been added following the destructive fire of 1272 . This would have served as an inexpensive method for giving a structure an architectural update without employing a mason. While some of the cosmetic patterns were retouched in 1870, they certainly endured throughout the Reformation. On the opposite side of the ambulatory, similar schemes have also survived on the apsidal arch of St. Luke's Chapel. This reveals that the increasing tendency towards plain whitewashed interiors was not universally implemented. The decorations were modest and practical enough to have gone untouched, as they seem to have been regarded as part of the fabric of the structure itself.

\subsection{Sculptures}

This section examines the sculpted roof bosses found at Norwich Cathedral that were spared any deliberates acts of iconoclasm, while a section in $\mathbf{C h a p t e r} \mathbf{V}$ will continue the analysis by assessing the damaged survivals in the same assemblage. 


\section{Case Study: Norwich Cathedral Roof Bosses}

Norwich Cathedral retains the most extensive collection of medieval sculptures, in the form of vaulted ceiling bosses, found anywhere in England. These bosses were intricately carved and decorated stone caps attached to the keystone intersection of a ceiling's rib vault. While Gothic architecture often included these decorative additions, the sheer number, and elaborate narratives featured surpasses the common motifs often observed, such as foliage, animals and grotesque figures. To put 1106 roof bosses at Norwich in perspective, the second highest concentration can be seen at Tewkesbury Abbey in Gloucestershire with approximately 250, with only 15 narrative carvings of the life of Christ (Rose, 1996, p. 363). This assemblage provides not only valuable insight into medieval Christendom, but a broad cross section of iconography in which to gauge the impact of the Reformation in Norwich.

The creation of these religious sculptures coincided with structural renovations to the Cathedral, often the result of interior fire damage. In 1463, lightning struck the spire of the building, causing extensive devastation to the nave as the wooden roof burned. Walter Hart, or Lyhert, bishop of Norwich at the time, saw this as an opportunity to provide the Cathedral nave with a rib-vaulted ceiling. The ensuing construction culminated with the addition of 336 sculpted and painted bosses. This collection provides a historiated narrative from east to west of the entire Bible, from Creation to the Apocalypse. The first seven bays recount various stories of the Old Testament, with the events found in the Book of Genesis spanning all the way to King David. The remaining seven bays are dedicated to the New Testament, telling the story of Christ, the Apostles and culminating in the eschatological events depicted in the Book of Revelation. Each bay has 24 intersections capped with a sculpted boss, of which six feature generic foliage. The details and craftsmanship dedicated to these pieces are staggering, as they were placed on a ceiling nearly 80 feet high and can barely be recognized, much less appreciated, from the ground below. One can almost imagine members of the laity pointing out bosses they could recognize as other would with the stars in the sky (Plate 19).

It is perhaps a testament to being hidden in plain sight that these iconographic treasures remained completely untouched by the Reformation and were spared any damage or 
whitewashing. The impracticality of targeting these artifacts aside, this motif was not designed for veneration; rather, they served as a visual representation of scripture utilized for the edification of the laity, both literate and illiterate (Ladick, 2011, pp. 54$55)$.

By 1509, the nave roof and spire had been rebuilt just in time for the outbreak of another fire, which destroyed the remaining wooden roof in both the north and south transepts. Bishop Richard Nykke, no doubt inspired by his predecessors, recognize the opportunity not only to vault the ceilings but continue the decorative scheme with own series of historiated bosses (Rose, 1996, p. 363). While the nave already covered most of the events found in scripture, it was decided that an additional, and more detailed, account of the Gospel would be appropriate. It should be observed that on the eve of Reformation, the extensive history of the Church was ignored in favor of a Biblical scheme that, while central, was already in use. The northern and southern transepts were built with four bays each, for a total of 192 bosses, with the story progressing from north to the south. The northern transept depicts events from the Gospels, from the birth of John the Baptist through the death of King Herod; while the southern transept continues the story and concludes with Jesus' ministry (Ladick, 2011, p. 55).

The cloister at Norwich Cathedral, positioned along the southern flank of the building, retains another collection of nearly 400 sculpted bosses affixed to the low vaulted ceilings. Within the context of Reformation iconoclasm, this series provides far greater insight than those found within the cathedral itself which were out of reach, if not out of sight and mind. Not only could the subject matter of these fittings be seen with the naked eye, but they could even be reached with minimal effort (Plate 20-21).

By 1272 , the ongoing tension between the city of Norwich and the cathedral close, the precinct of property within the city limits that fell under its own episcopal or monastic jurisdiction, exploded into widespread rioting which resulted in the destruction of all Norman structures used by the priory, including the cloisters. The process to rebuild was undertaken in phases over the following century, with the addition of roof bosses added to intersections in the 49 bays. 
The entire collection appears to provide a truncated account of the entirety of Christian history, starting with the natural and abstract bosses on the eastern walk which were akin to Creation, and thus, closest to God. The construction of the east walk, running along the southern transept of the cathedral, was the first portion to be completed and adorned with roof bosses, with the earliest examples located in the central four bays just outside of the new chapter house. All 36 of these proto-bosses bore a simple foliage motif, setting the stage for the significant expansion of the medium and use of increasingly sophisticated schemes.

In addition to the foliage and grotesque figures, the east walk possesses the start of a Christological scheme that recounts the Passion of Christ, from flagellation to the harrowing of Hell. The collection was reserved for the most sacred of spaces, as its northern placement along the east walk provided the nearest proximity to the altar, in addition to being just outside of the Prior's door into the cathedral.

This New Testament narrative extends to the south, with events from early in the life of Christ, such as the Annunciation, Visitation, and beheading of John the Baptist. The remaining sections of the south walk begin a new cycle which extends into the west walk of over one hundred (107) bosses recounting the series of events described in the eschatological conclusion to the New Testament, the Book of Revelation. Outside of wall murals, this motif was a very uncommon form of Christian iconography in the Middle Ages, as the mysterious nature of the account would be quite difficult for the average parishioners to comprehend. The innovative imagination of the bishop and prior who authorized the production of this scheme on this scale, as the early implementation and use of stone as a medium is unprecedented across in Europe (Rose \& Hedgecoe, 1997, p. 288). These particular Apocalyptic images were purchased by the Cathedral as construction began on the west walk in 1346 and provided the finishing touch upon its completion (Heywood, 1996, p. 102). This exceptional achievement must have inspired the carvers to produce a final collection of bosses as magnificent as the Apocalypse cycle, which would serve a grand finale to adorn remaining sections of the west and north walk; meeting the Passion scheme on east walk completed over a century prior. The craftsmen did not disappoint, as features north walk continues to story of the Christ with the post-Resurrection and the 
martyrdom of the apostles as depicted in the Book of Acts. From here, the series continue, featuring both stories from Catholic tradition and saints, including the life and coronation of the Virgin, and an array of extrabiblical saints, including: St. Laurence on a gridiron, St. Martin on horseback, St. Clement, St. Nicholas, St. Thomas of Canterbury, Henry II, and St. Theophilus of Adana, St. Edward the Confessor, St. Denis, St. Catherine, St. Lucy and St. Giles. This post-scriptural motif continues into the west walk with bosses recounting both the accounts of St. Christopher and the legend of the Christians of Constantinople, which meets the conclusion the Apocalypse set of bosses mentioned earlier.

The inclusion of this collection of undamaged bosses provides valuable insight into the nature of motifs which were spared deliberates acts of iconoclasm during the period. In the following chapter, we will examine other bosses in the assemblage which suffered mutilation and assess the nature of offensive iconography. 

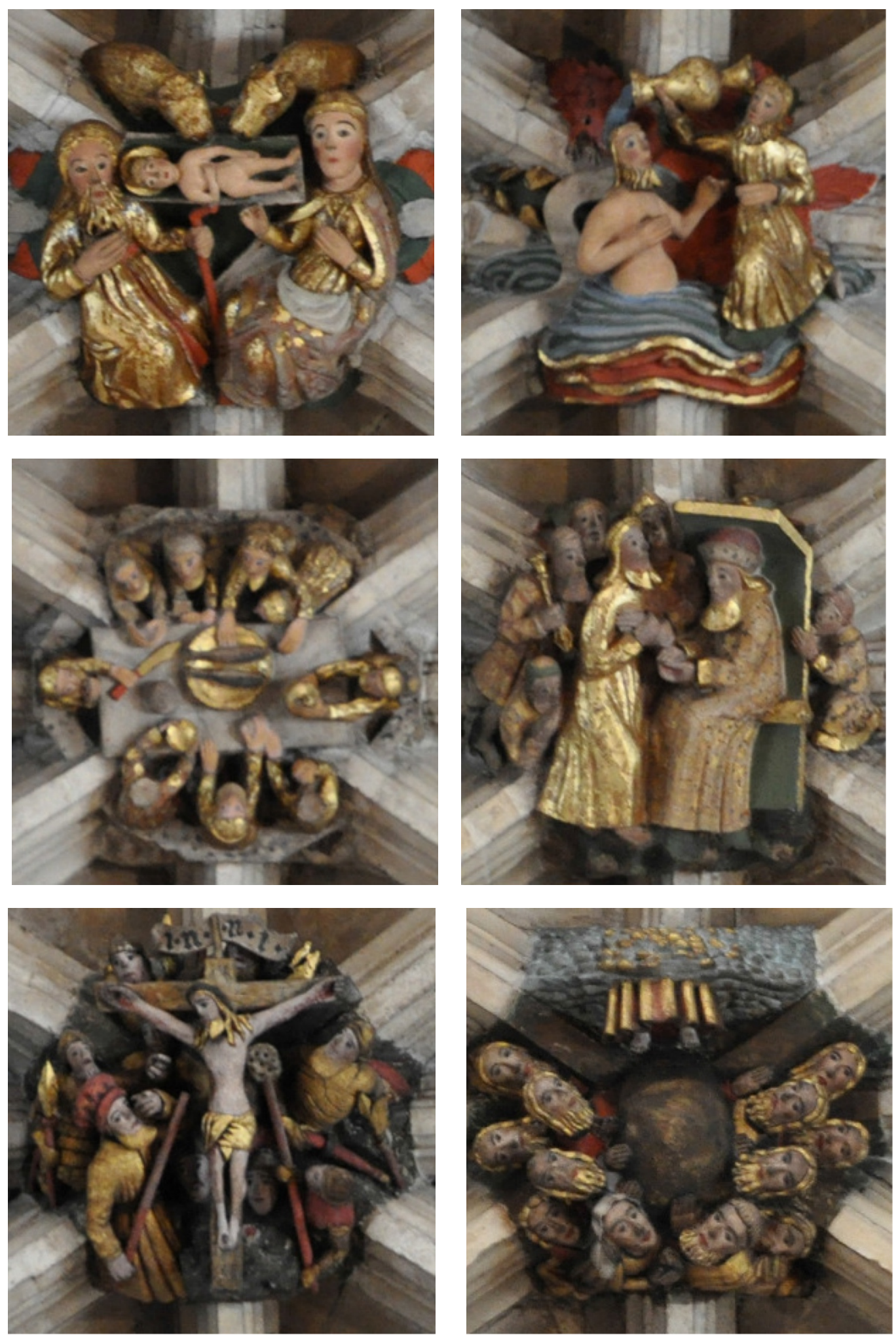

Plate 19: Sculptures: Norwich Cathedral Nave 

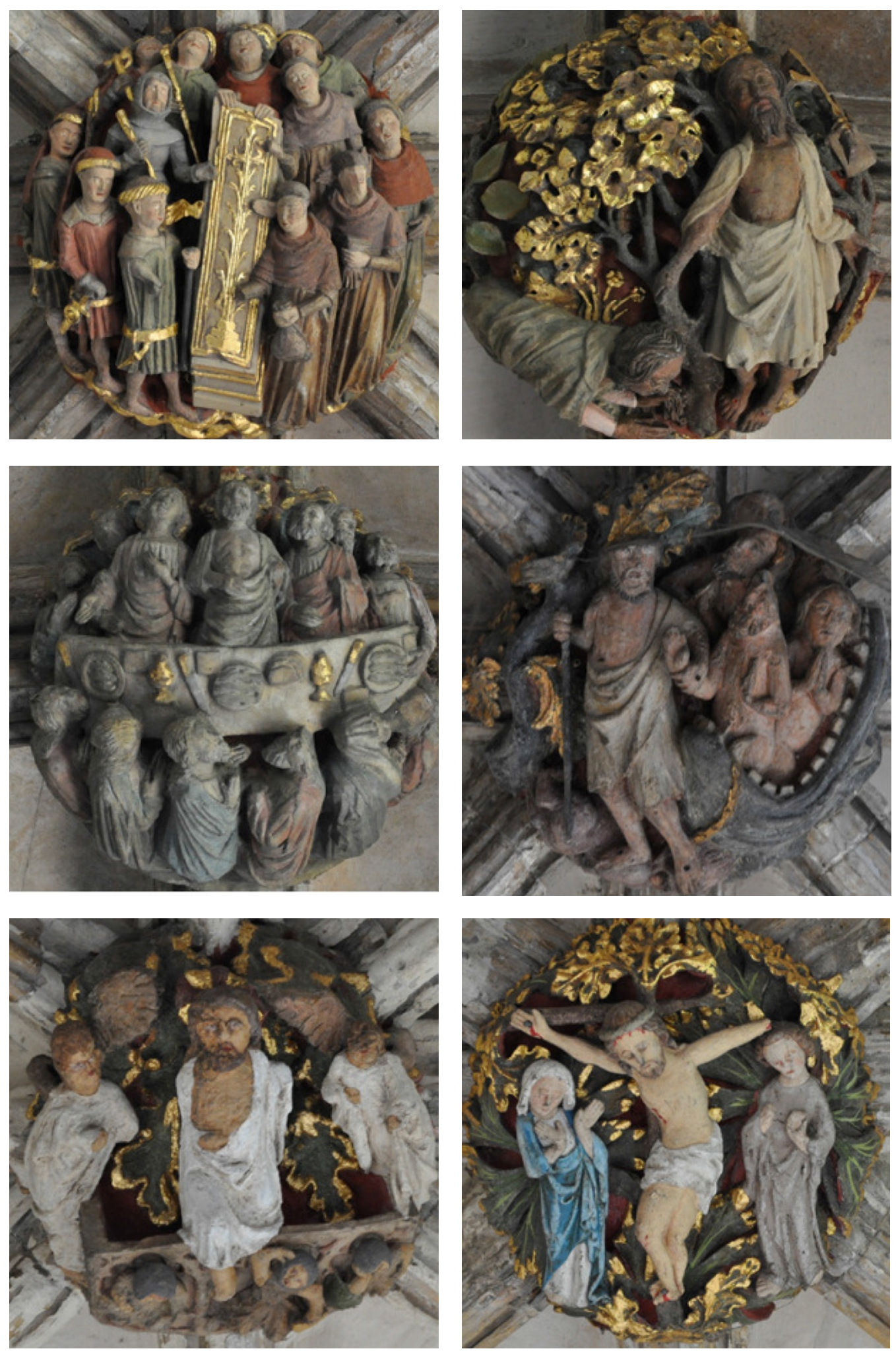

Plate 20: Sculptures: Norwich Cathedral Cloister. Part One 

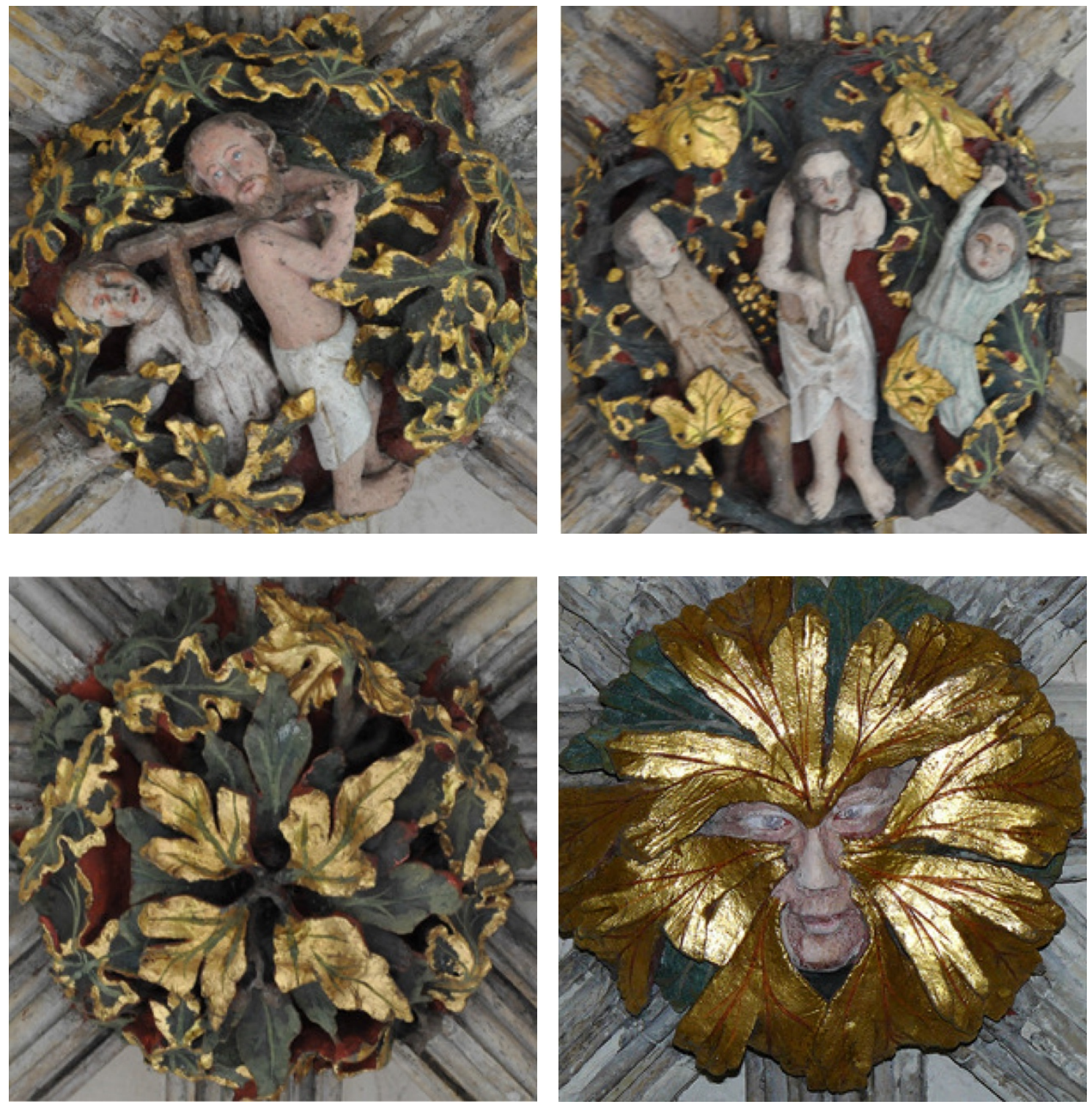

Plate 21: Sculptures: Norwich Cathedral Cloister. Part Two

Plate 19: Nativity; Baptism; Last Supper; Christ's arrest; Crucifixion; Ascension.

Plate 20. Sealing of the tomb; Christ with Mary Magdalene; Breakfast with disciples;

Harrowing of Hell; Resurrection; Crucifixion.

Plate 21. Carrying of the Cross; Scourging of Christ; Foliage; Green man. 


\subsection{Pulpits}

Medieval pulpits constructed of stone and wood have survived across England, as preaching for the purpose of educating the laity was an integral component of the Church. Priests required a license to take the pulpit, which was often used to teach core doctrines in the common tongue, such as the fourteen articles of belief outlined by Thomas Aquinas in the Summa theologiae, the Ten Commandments, and the seven works of mercy, capital sins, virtues and sacraments. (Cox, 1915, pp. 2-4). In other cases, sermons and passages of Scripture were read aloud in Latin for the benefit of those who could understand, such as educated member of the laity or even in to the monastic clergy during meal times (Cox, 1915, p. 36). Another important function of these pulpits was for a priest to proclaim a bidding prayer, where a prayer for the welfare of the parish, clergy, and secular authorities was offered up publically (Cox, 1915, pp. 18-19). If a church did possess a pulpit, these activates would often take place from a practical vantage point, such as from the chancel steps.

St. Margaret church at Burnham Norton retains a hexagonal oak wineglass pulpit featuring six figures painted within a carved ogee arches and against alternating red and green background. This richly decorated fixture was provided at the expense of a John and Katherine Goldalle in 1450 (Nichols, 2002, p. 154). In accordance with the educational implications of a pulpit, images of Latin Doctors, all wielding a pen and scroll, are featured on four panels of the six panels. The only notable damage is the usual scratches evident on St. Gregory's papal tiara, however, the St. Jerome's anachronism cardinal's hat. The two remain panels feature Goldalle and his wife, who are clearly identified with a dated Latin inscription (Blomefield, 1807, p. 17). It is possible this generous donation was made as an act of public contrition, as Goldalle has been arrested four years earlier for stealing oysters from the salted marshes (Bryant, 1914, pp. 26, 187 ).

Castle Acre retains a hexagonal oak wineglass pulpit which is quite similar to the one found at Burnham Norton. The primary difference between these two fixtures is the lack of the two donor panels, which remain blank here. It has been suggested that the reason for this is that these images were not originally intended for the pulpit and had 
been repurposed from an earlier dismantled parclose screen. (Alexander, 1994). The inclusion and endurance of this motif on two separate pulpits demonstrates not only the importance of preaching in the late medieval church, but also the significance the Latin Doctor in their association with teaching. 


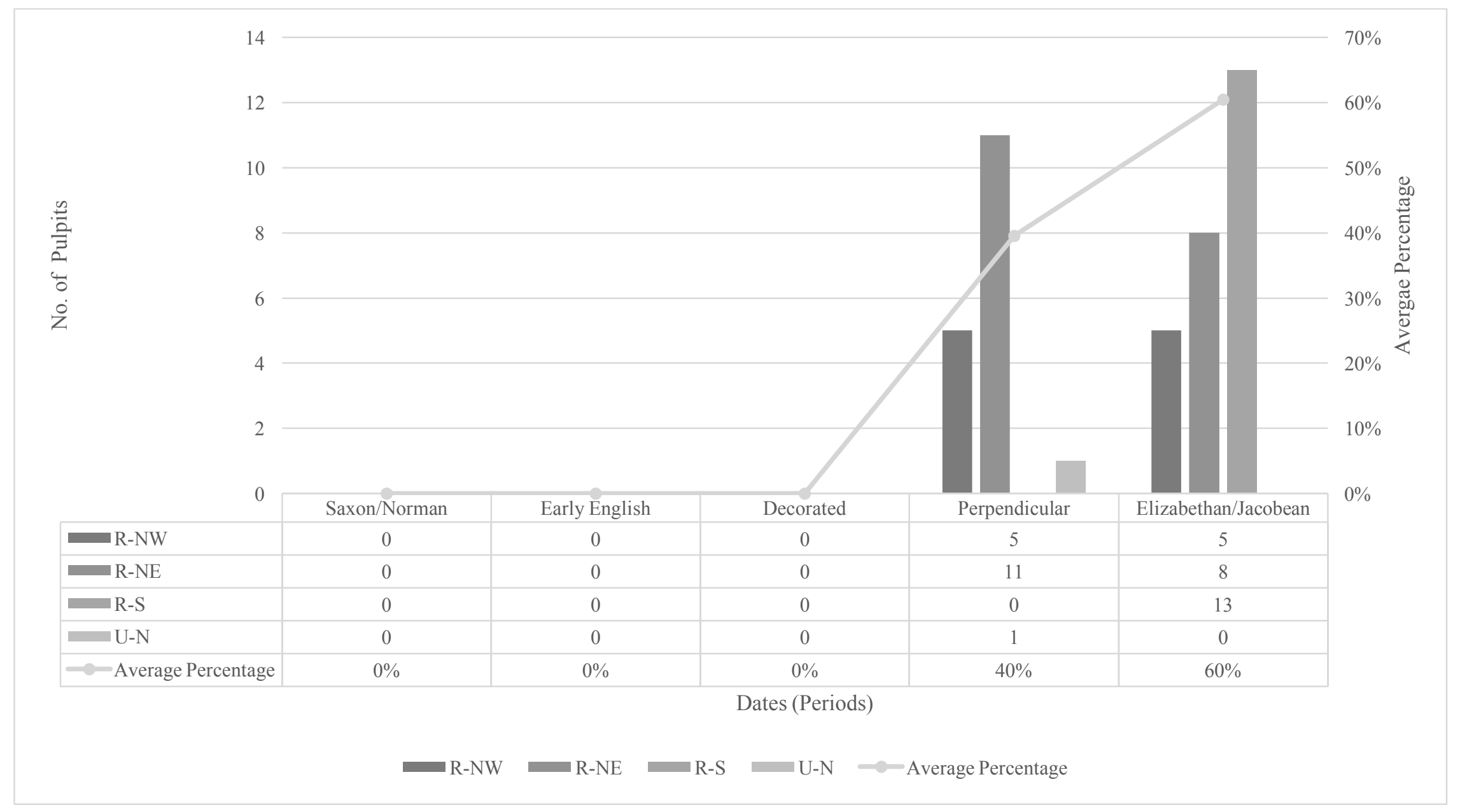

Figure 10: Pulpits: Chronological Distribution 


\begin{tabular}{|c|c|c|c|c|c|}
\hline Sample & & Church & Pulpit & Percentage & Per Church \\
\hline & & (c) & $(f)$ & $(\% f)$ & $(f / c)$ \\
\hline \multirow[t]{6}{*}{ R-NW } & Brothercross & 10 & 3 & $30 \%$ & 0.30 \\
\hline & Freebridge-Lynn & 36 & 1 & $10 \%$ & 0.03 \\
\hline & North Greenhoe & 21 & 3 & $30 \%$ & 0.14 \\
\hline & Smithdon & 20 & 3 & $30 \%$ & 0.15 \\
\hline & King's Lynn & 3 & 0 & $0 \%$ & 0.00 \\
\hline & TOTAL & 90 & 10 & $100 \%$ & 0.11 \\
\hline \multirow[t]{5}{*}{ R-NE } & Blofield & 19 & 1 & $5 \%$ & 0.05 \\
\hline & South Erpingham & 39 & 8 & $42 \%$ & 0.21 \\
\hline & Taverham & 19 & 5 & $26 \%$ & 0.26 \\
\hline & Tunstead & 26 & 5 & $26 \%$ & 0.19 \\
\hline & TOTAL & 103 & 19 & $100 \%$ & 0.18 \\
\hline \multirow[t]{5}{*}{$\mathbf{R}-\mathbf{S}$} & Depwade & 23 & 5 & $38 \%$ & 0.22 \\
\hline & Diss & 16 & 4 & $31 \%$ & 0.25 \\
\hline & Guiltcross & 14 & 1 & $8 \%$ & 0.07 \\
\hline & Shropham & 23 & 3 & $23 \%$ & 0.13 \\
\hline & TOTAL & 76 & 13 & $100 \%$ & 0.17 \\
\hline $\mathbf{U}-\mathbf{N}$ & Norwich & 45 & 1 & - & 0.02 \\
\hline TOTAL & & 314 & 43 & - & 0.14 \\
\hline
\end{tabular}

Table 12: Pulpit: Population 


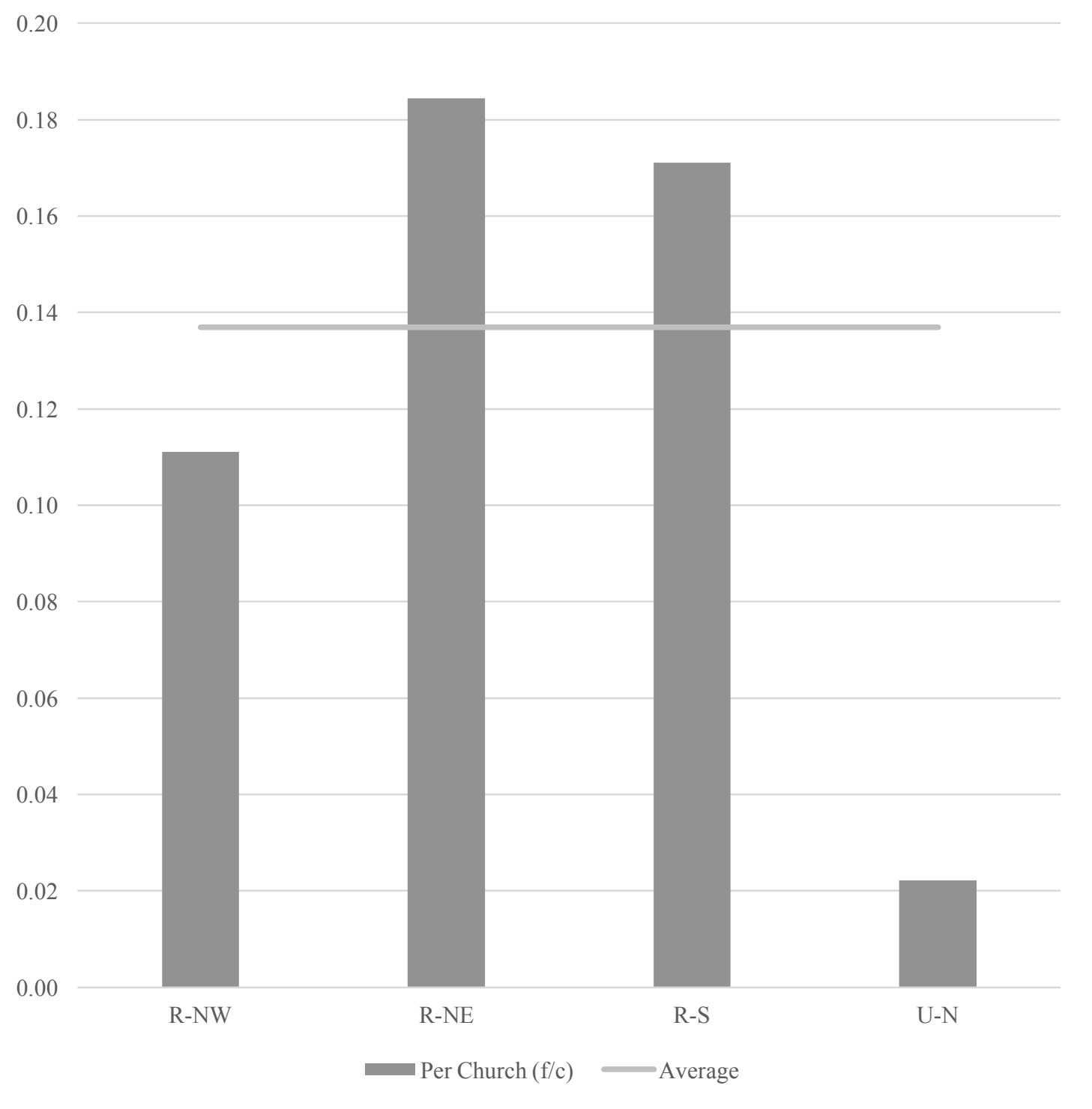

Figure 11: Pulpits: Per Church 


\subsection{Hidden Icons}

As the aforementioned fittings all have their own story of survival to tell, it is important to address those which were purposefully rescued from destruction through concealment. These undocumented activities present a unique challenge for archaeologists in their attempt to provide context to pre-Reformation survivals, essentially an archaeology of "hide and seek" (Aston, 2003, p. 21). In 1565, the the practice of hiding idols was acknowledged by Bishop Benthem of Coventry and Lichfield, who instructed his clergy to to abolish all "monuments of idolatry and superstition... and all idols laid up in secret places in your church" (Aston, 1988, p. 318). Just as a Catholic restoration was possible through the installation of the wrong monarch or the machinations of foreign regimes, the physical icons of the old religion could be excavated from the shadows and resume their corrupting influence.

A significant example of a hidden medieval icon surviving the Reformation is a brass pelican lectern at Norwich Cathedral. This fifteenth century fitting may have been Flemish in origin before being acquired by the Cathedral, which would be very consistent with the prominent Walloon population located in the city (Pevsner \& Wilson, 1997, p. 69). The

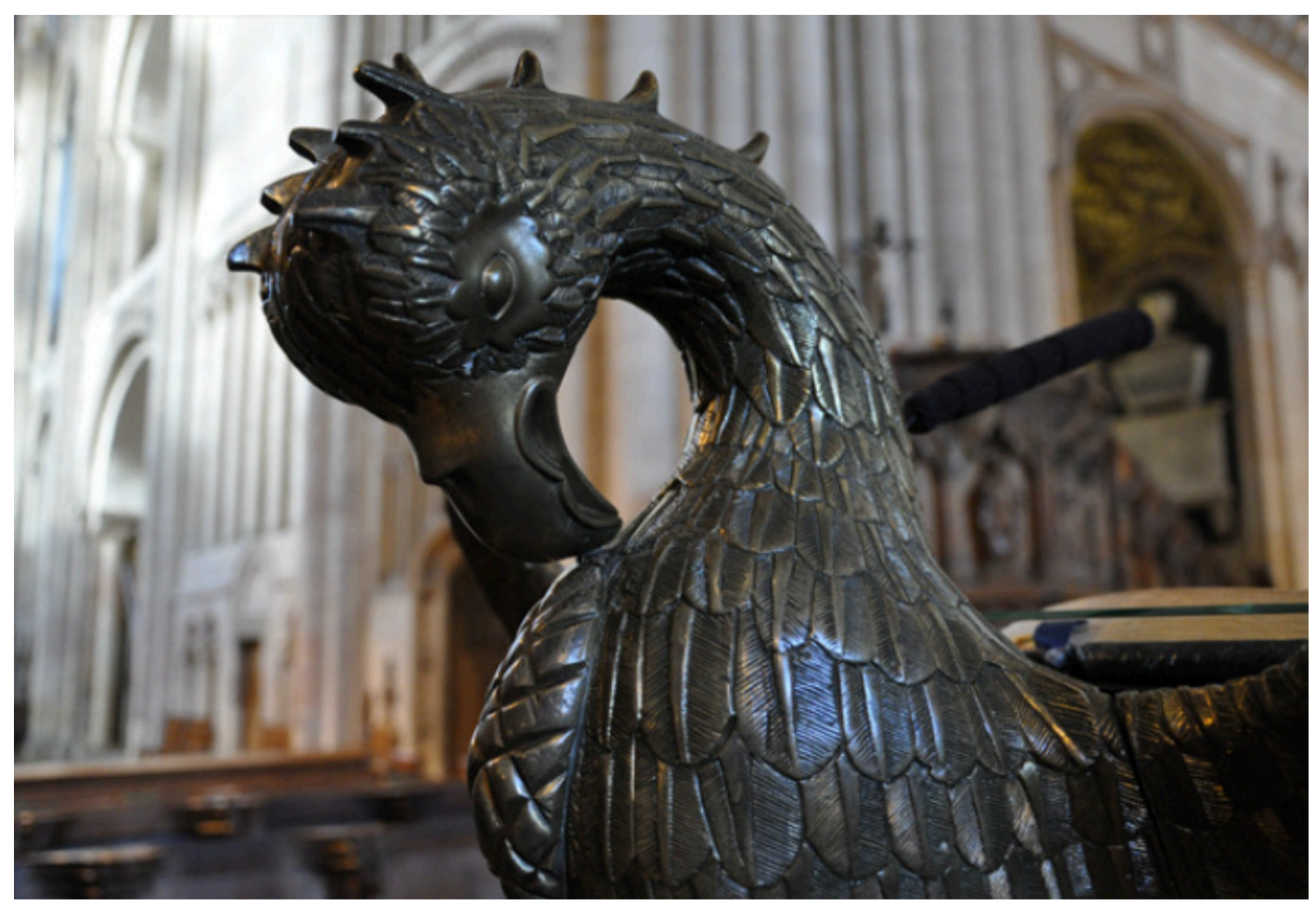

Plate 22: Lectern: Norwich Cathedral 
medieval symbolism of the pelican is associated with Christ, as the bird kills its own children in self-defense, before it pierces its own side and allows the blood to resuscitate them. The lectern was eventually hidden away and buried in the Bishop's Garden, near the Jesus Chapel, in 1643 (Wills, 1962, p. 113). While the Christological implications of the bird motif may not have been as offensive as the veneration of saints, it may have still been lost to puritan soldiers for its metal just as many floor commemorations were. Following the emergence of the icon from hiding, the lectern was adorned with three additional figures of a bishop, a priest and a deacon in 1845 (Cox, 1915, p. 165).

\subsection{Conclusion}

The church fittings examined across the four samples groups in this chapter demonstrated the sacramental, decorative and functional commonality seen in surviving medieval church fittings. Iconography depicting figures from Scripture survived at a much higher rate those derived from extrabiblical accounts. This observation appears to extend beyond images of saints and to even more obscure medieval schemes that had a direct or indirect connection of Christ. One glaring exception to these findings are depictions of the Latin Doctors, which were often modified to suppress the strong papal associations with this collective of figures.

Fittings decorated with images and schemes connected to local identity also had strong rates of survival. Paintings and carving tied to agrarian and folk identity were spared, as were many depicting the patron saint of England. It was also demonstrated the totality of influence the manor could have on a parish church, whether it be a power aristocrat, a local family or a monastery. Finally, the fittings that survive at the highest rates are baptismal fonts and screens. These valuable fittings provided a parish with generational continuity, which no doubt influenced the decisions to modify or remove them during the Reformation. These results, and how they tie into the wider themes and research questions, will be assessed the Chapter VII discussion section 


\section{Chapter V: Reformation: Iconoclasm}

This chapter will present a detailed analysis of medieval church fittings, predating the 1534 Acts of Supremacy, which suffered defacement or destruction during the following 126 years of religious transition, transformation and upheaval defined as the 'Reformation' in this study. Unless a fitting is directly referenced in the written record, it becomes a difficult task to determine the exact nature and circumstances of its defacement; however, the common periods of targeting images, such as portions of the Henrican reign, the entirety of the Edwardian reign and the English Civil War of the seventeenth century will be examined as possible candidates. The evidence supports a broader interpretation of the religious imperative of early reformers, and later of Anglicans and Puritans. It will be argued that mainstream reformers were far more pragmatic than the abusive iconoclasts they have been traditionally portrayed as, with a sense of practicality and emotional resonance governing their actions in the modification of church interiors.

\section{Edwardian Inventories}

The compilation of the Inventories continued from the autumn and into the winter of 1552 until the Privy Council ordered the first wave of confiscation in January 1553. The liturgical outlines described in the 1552 Book of Common Prayer provided the baseline requirements for what each church was to be left: a chalice and modest communion table cloth for the Eucharist; a simple surplice for the clergy; and a collection of integral writings like the Bible, a psalter and the latest prayer book (Duffy, 2012, pp. 126-29). Other furnishings, like baptismal fonts and rood screens, were also to remain as long as their decoration complied with the decrees against images. Unlike the 1536 uprisings in Lincolnshire and Yorkshire or the 1549 uprisings in Devon and Cornwall, these significant alterations to parish life unfolded without any trouble. If any moment in the Reformation should have sparked a popular resistance to the Protestant direction in which the country was moving, it certainly should have been this. The political reforms spanning the period from the Royal Supremacy to this moment moved closer and closer into affecting the lives of the common people; this bold move directly into the parish church was the coup de grâce for the traditional religion, now no longer able to thrive at a local level. 
After six months of stripping the parish churches, Edward's death on the sixth of July 1553 cast a shadow of uncertainty as to whether this campaign would continue under his successor. Within weeks, Princess Mary was proclaimed from Norwich, as she had fled London to rally support from the Howard family. With the memory of Kett's rebellion still lingering in the collective memory of the county, the people rallied to her cause and aided her in securing the throne (Bayne, 1869, pp. 203, 694). Following the ascension of Mary, it was still unclear how the new Catholic queen would handle the consequences of her predecessor's actions. In an attempt to show support for his new monarch, Henry Crooke, Mayor of Norwich, ordered a chest of seized church plate be opened and sent to the new queen (Duffy, 2012, p. 127). Although the Edwardian policies of confiscation would have provided her new government with badly need funds, Mary proceeded with a strategy of restoration by the autumn of her first year. The sheer logistics of this campaign were idealistic at best, as much of the church plate had already been melted down upon its arrival at the Jewel House in the Tower of London. Other confiscated valuables were still being stored at local depots, where former royal commissioners were tasked to aid in the identification and return of these items to the appropriate parishes. In order to be carried out effectively, this enterprise would require time and passion from the former commissioners, two things this Catholic reign would be too short to support.

The death of Queen Mary and accession of her half-sister Elizabeth in 1558 halted restoration of church goods and ensured the damage done by the Edwardian regime would be lasting. The following year saw a new series of Royal Visitations designed to enforce both iconoclasm and the suppression of Catholic rituals; however, the confiscation of any restored or newly commissioned church valuables was not reinstituted (Duffy, 2012, p. 128). Perhaps it was clear that the injury already inflicted on the material culture of the parish churches was grave enough to ensure a return to Catholic ritual at a local level was going to be unlikely. The loss of certain communal elements of the parish church, such as the remembrance of the dead through prayer, shifted focus to the economic divide amongst the parishioners in a new and even more striking fashion. While the majority were deprived of any ecclesiastical outlet for remembrance, the wealthy could still commission monuments, brasses or ledger slabs. 
The assault on parish life thus instituted, from confiscation to restoration and back, did not create this divide, but it did remove the illusion which occasional blurred these lines in maintaining a strong sense of community. Elizabeth may not have wanted to make windows into men's souls, but the Tudor government's transformation of parish life ensured many of those souls would no longer retain the material culture they required to be Catholics.

\begin{tabular}{|c|c|c|c|}
\hline & R-NW & R-NE & $\mathbf{R}-\mathbf{S}$ \\
\hline Chalice & 79 & 96 & 67 \\
\hline Paten & 53 & 82 & 50 \\
\hline Pyx & 5 & 12 & 12 \\
\hline Cope & 74 & 92 & 63 \\
\hline Bell/Clapper & 80 & 90 & 69 \\
\hline Vestments & 70 & 87 & 60 \\
\hline Cross Clothe & 4 & 6 & 7 \\
\hline Altar Clothes & 29 & 33 & 22 \\
\hline Albes & 8 & 19 & 16 \\
\hline Candlestick & 17 & 46 & 26 \\
\hline Organ & 5 & 0 & 4 \\
\hline Cross (Copper/Latten/Silver) & 20 & 43 & 32 \\
\hline Plates/Dishes & 1 & 1 & 0 \\
\hline Senser & 1 & 19 & 9 \\
\hline Totals & 446 & 626 & 437 \\
\hline
\end{tabular}

Table 13: Edwardian Inventory in Rural Samples 


\section{Parliamentary Visitation}

It is possible that a correlation can be made between levels of iconoclasm in England during the Reformation and early proto-Protestant notions espoused by the fourteenth century Oxford theologian, John Wycliffe, and his followers. While Lollards appear to have still existed in Norfolk at the dawn of the Reformation, they seem to have been attracted to the unfolding events rather than having any influence on them (Bray, 1994, p. 17). Historian Eamon Duffy (1992) engages this phenomenon by acknowledging, but never overstating, their influence on the unfolding events of the Reformation. Additional work done on the correlation between Lollard social statuses in East Anglia reveals a higher concentration of Lollards along Norfolk's southeast border with Suffolk (Jurkowski, 2007). This phenomenon will be assessed against the rate of survival and destruction determined by this study.

A revival of iconoclast activity took place in Norfolk in the mid-seventeenth century as the conflict between King Charles I and Parliament launched the religious landscape back into turmoil. Elaborate medieval survivals or High Church innovations were targeted for what could have proved a final purge of the last vestiges of medieval Catholicism. In many counties, commissioners sanctioned by Parliament swept across the country to inspect parish churches and enforce the 1643 ordinances against images. The previous year saw the Parliamentarian militias of Essex, Hertfordshire, Norfolk, Suffolk, and Cambridgeshire consolidate as the Eastern Association, with Huntingdonshire and Lincolnshire joining shortly thereafter. Within a year, Edward Montagu, second earl of Manchester, was appointed as the commanding officer of the organization, with the cavalry wing under the charge of Oliver Cromwell. Manchester was ordered to carry out inspections across his counties for the destruction of idolatrous or superstitious monuments, and appoint commissioners to this end (Morrill, 2001, p. 12). The most notable case to emerge from this enterprise was the work of William Dowsing, Provost-Marshall in the Eastern Association, who conducted the visitations of Cambridgeshire and Suffolk, which he personally recorded in a detailed journal.

Tracing these events in Norfolk is more difficult without such a detailed account; however, churchwarden accounts across the south of the county reference a Captain Clement Gilley, who was the likely commissioner for this region. Most of Gilley's 
work was confined to the $R-S$ sample of this study; church bells inscriptions were his trademark target as every church on the road from Norwich down to Suffolk features damaged bells (Blatchly, 2001, p. 109; Jessopp \& James, 1896). The $R-N W$ and $R-N E$ samples show inconsistent signs of systematic iconoclasm fueled by an external impetus, which can either be a testament to the shortage of manpower under the command of Gilley or the reliance on local bureaucracies to enforce the ordinances, as can be seen in Besthorpe and Fritton. Parish churches that straddled the line between rural and urban, like St. Margaret's in King's Lynn, saw the iconoclastic activity reluctantly carried out by its churchwardens, but not without referencing the economic hardships of enforcing the law (Blatchly, 2001, pp. 118-119).

The $U-N$ sample of Norwich handled the enforcement of the parliamentarian ordinances differently and independently, as they enforced them by establishing their own committee in January 1644 (Blomefield, 1806, pp. 385-398). This committee, which included aldermen and churchwardens, was loyal to Parliament and appointed three commissioners with puritanical inclinations to conduct the church visitations across the city. The subsequent iconoclast purge was carried out by Alderman Matthey Linsey, a grocer and future mayor; Alderman John Greenwood; and Sheriff Thomas Toft, who performed civil marriages as late as 1657 before losing power at the Restoration. In May 1547, the trio moved against Norwich Cathedral and Bishop Joseph Hall, while continuing to order the removal of images across the city for public burning in the market near St. Peter Mancroft. Following his eviction from the palace, Hall recorded the harsh desecration he witnessed at the Cathedral; of which evidence still endures to this day. Many churches, like St. John Maddermarket and St. Gregory, complied with the commissioners and went to work repairing the damage; while others like St Mary Colsany were already in compliance as a result of the Edwardian purges in the previous century (Blatchly, 2001, pp. 121-122). In spite of the enthusiastic compliance across the 'godly' city, several parishes rejected the excesses of the destruction on theological and even political grounds. John Utting, mayor of Norwich (1647), churchwarden of St. Peter Mancroft, and a known Royalist, was able to resist the commissioners until Parliamentary troops arrived to relieve the embattled mayor of his position. The ensuing riots culminated in the supporters of Utting igniting a stash of gunpowder housed at the Committee House on Bethel Street; which ironically 
destroyed the grand east window of his church. Other cases of resistance came in the form of ministers unleashing sermons critical of the commissioners, like Charles Davill of St. Laurence who publically attacked the destruction of images and the degrading of the clergy (Hooper, 2004, p. 104).

\subsection{Baptismal Fonts}

As seen in the previous chapter, baptismal fonts were often spared from complete destruction, as they were still required for Anglican liturgy as a sacramental or even symbolic expression of faith. The issue to arise is that these prominent, and costly, fixtures often featured elaborate decorations in paint or stonework. While the paintwork could be hidden easily enough through whitewashing, the carvings required more effort to obscure. This could be achieved through either filling in the panels with plaster, which could be financed through the selling of church plate, or more usually economical mutilation by chisel. The latter would provide a sense of finality in terms of the religious direction the reformers were embarking on, with the damaged facade providing a permanent reminder of their new position in regards to visual idolatry.

Baptismal fonts were addressed through official policy at several junctures of the unfolding religious reform in England. In 1561, Elizabeth I issued a royal order that fonts not be relocated, most likely to address the continental trends of repositioning the fittings toward the front of the church near the pulpit. This official position was reinforced in the 1604 Book of Canons, which reiterated that fonts should remain in the same location they had since their inception. Following the outbreak of the first conflict between Royal and Parliamentarian forces, medieval stone fonts were ordered to be "utterly defaced" and replaced with simple basins (Firth \& Rait, n.d.). In 1645, the Directory for Public Worship was approved to supersede the Book of Common Prayer and promoted a more puritanical expression of faith. This publication required that all fonts be moved to the front near the communion table, a costly and impractical request in most cases (Spraggon, 2003, pp. 78-80, 105, 115). The following year, churchwardens were again instructed to remove fonts, although most scholars agree that this provision referred to holy water stoups often found near the church entrance (Morrill, 2001; Spraggon, 2003, p. 79). 
Fonts decorated with the seven sacrament motif, a scheme found almost exclusively in East Anglia, did not fare well during the Reformation in terms of remaining unmolested. The catechetical teachings espoused through these fonts are indicative of the ideal representation of the Roman Catholic sacraments, which are an approximation as defined by the laity who usually commissioned their construction. The influence of heretical movements, such as the Lollards, may have initially influenced the desire to present these sacraments in their purest and most accurate form as a countermeasure (Duffy, 1992, p. 66). This desire, combined with the wealth procured from the wool trade, enabled an excess of these fonts in the fifteenth century, subsequently defaced during the following century.

In the wake of Reformation, the importance of Marian veneration diminished as a result of the extra-biblical prominence placed on her within Catholic theology, combined with a backlash against her elevated role as a mediator alongside Christ. As a result, images of the Virgin fell victim to many deliberate acts of iconoclasm as her inclusion was considered offensive and idolatrous. Her role as the mother of Christ, as described in Scripture, emerged as the acceptable basis for her inclusion in the new Church of England, as evidenced by the elimination of the August 15 feast day commemorating the Assumption in 1561 in place of a general commemoration. The remaining Marian feast days, such the presentation of Christ at the Temple (February 2; Luke 2.22-40), the Annunciation (March 25; Luke 1.26-39), the visitation with Elizabeth (May 31; Luke 1.39-56) present a biblical view of the Virgin, with the conception (December 8) and birth (September 8) celebrated as lesser festivals. As a baptismal font decoration, the Virgin is still visible on only two fonts in each rural sample with all six depictions retaining signs of mutilation and no remaining survivals in Norwich. These meager survivals of one of the most prominent subject matters in medieval art suggests the wholesale proscribing of the image, most likely on lost fonts, or even skillful cement filling or recutting. 


\begin{tabular}{|c|c|c|c|c|}
\hline & & Icons & Damaged & Rate \\
\hline & & (i) & (d) & $(d / i)$ \\
\hline \multirow[t]{6}{*}{ R-NW } & Brothercross & 4 & 3 & $75 \%$ \\
\hline & Freebridge-Lynn & 15 & 3 & $20 \%$ \\
\hline & North Greenhoe & 19 & 4 & $21 \%$ \\
\hline & Smithdon & 13 & 5 & $38 \%$ \\
\hline & King's Lynn & 2 & 0 & $0 \%$ \\
\hline & TOTAL & 53 & 15 & $28 \%$ \\
\hline \multirow[t]{5}{*}{ R-NE } & Blofield & 14 & 1 & $7 \%$ \\
\hline & South Erpingham & 40 & 9 & $23 \%$ \\
\hline & Taverham & 11 & 1 & $9 \%$ \\
\hline & Tunstead & 25 & 4 & $16 \%$ \\
\hline & TOTAL & 90 & 15 & $17 \%$ \\
\hline \multirow[t]{5}{*}{$\mathbf{R}-\mathbf{S}$} & Depwade & 38 & 5 & $13 \%$ \\
\hline & Diss & 23 & 3 & $13 \%$ \\
\hline & Guiltcross & 3 & 0 & $0 \%$ \\
\hline & Shropham & 17 & 4 & $24 \%$ \\
\hline & TOTAL & 81 & 12 & $15 \%$ \\
\hline $\mathbf{U}-\mathbf{N}$ & Norwich & 35 & 8 & $23 \%$ \\
\hline TOTAL & & 259 & 50 & $19 \%$ \\
\hline
\end{tabular}

Table 14: Baptismal Fonts: Iconoclasm 


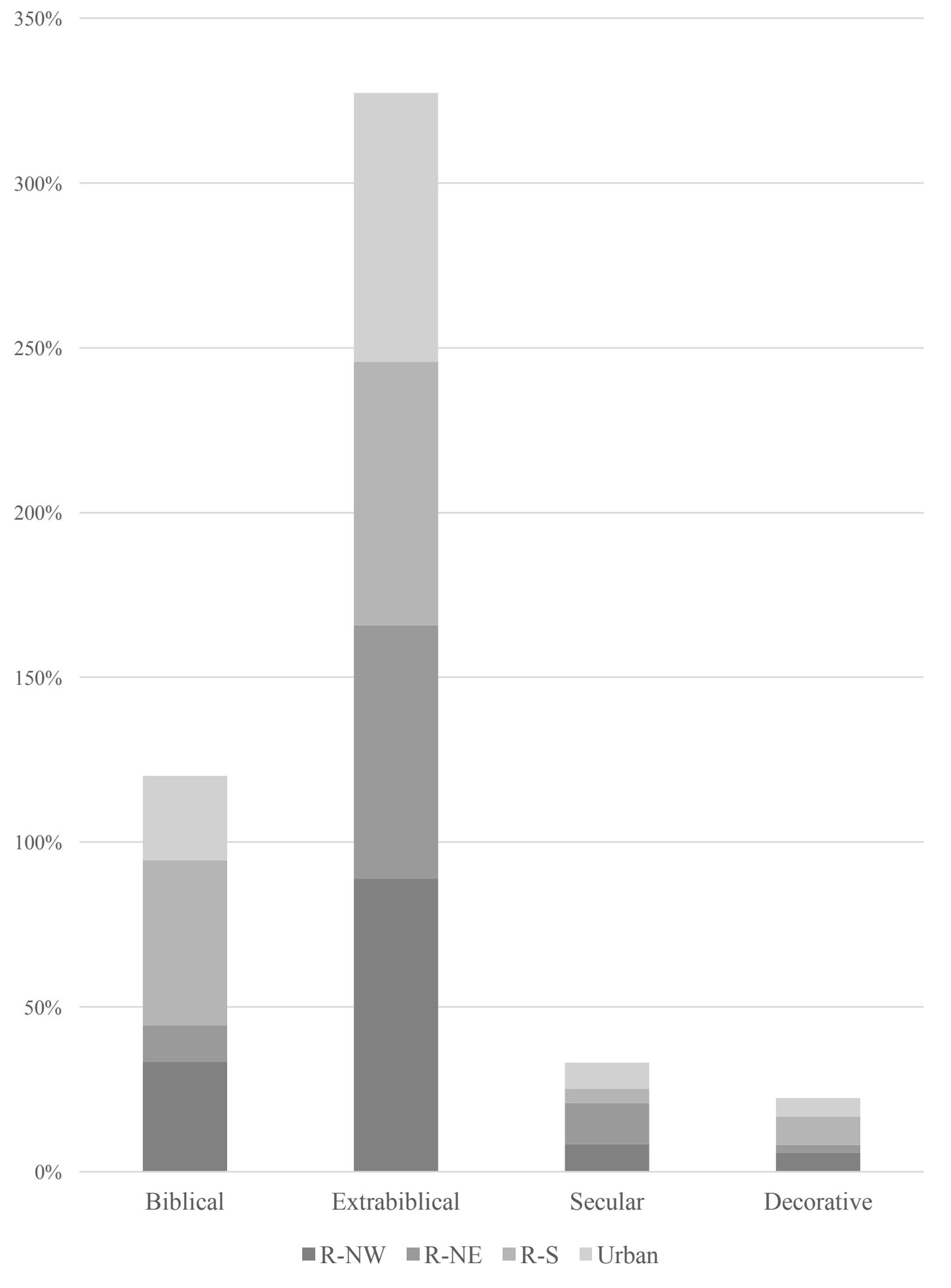

Figure 12: Baptismal Font: Rate of Iconoclasm 


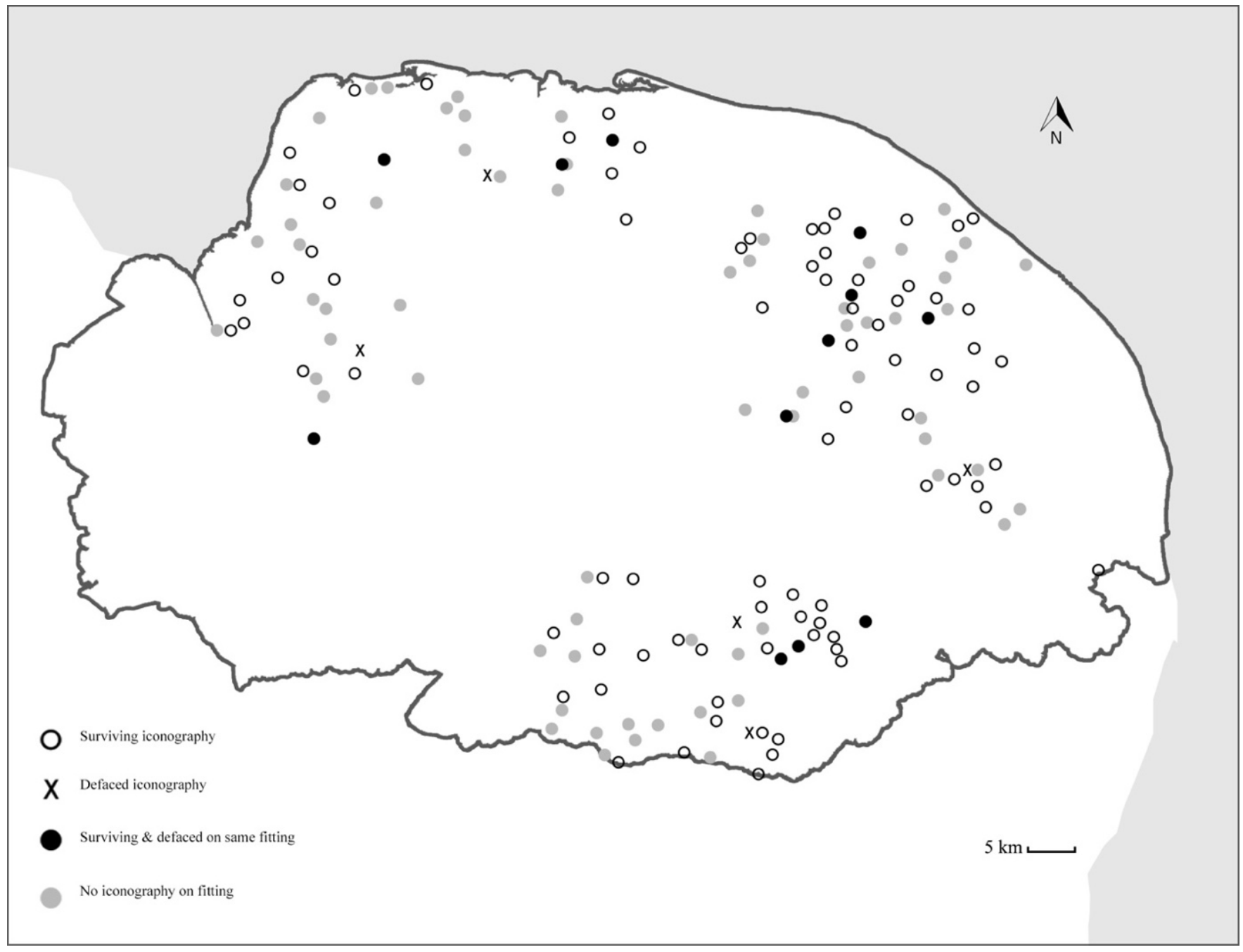

Figure 13: Baptismal Fonts: Map Distribution 


\section{R-NW Sample}

Three case studies were selected for this sample group, as baptismal fonts at Binham, Gayton Thorpe and Docking will be examined. Both Binham and Gayton Thorpe feature damaged carvings depicting the seven sacraments of the Catholic Church, while Docking features mutilated figures of female saints. All three parishes were under the influence of a monastery until the Dissolution, and in the case of Docking, actually shared a building.

\section{Case Study: Binham}

The coastal village of Binham provides an example of rural religious life intimately connected to a monastic authority; the entire parish was served directly by Binham Priory and operated out of the nave. In the wake of the Conquest, this Benedictine monastery was founded by Peter de Valognes as a dependent house of St. Alban's Abbey in Hertfordshire, although it was officially considered a subject of Cluny Abbey in France (Blomefield, 1809, p. 209). The priory was further endowed with the lordship of the parish, rendering it the undisputed ecclesiastical and secular authority in the area.

During the reign of King John (1199-1216), this special blend of church and state eventually led to a dispute between church officials which erupted into a conflict set within the broader struggle between the monarch and his barons. In wake of a dispute over ownership of Northaw Wood between Robert Fitzwalter and John of Wallingford, abbot of St. Albans Abbey, Thomas, prior of Binham, chose to support the former's claim. In retaliation, Wallingford exercised his monastic authority and deposed Thomas from his position. These actions led Fitzwalter to claim dominion over the patronage of Binham and besiege the priory in an attempt to reinstate his supporter (Bryant, 1898, p. 2; BAA, 1858, p. 167). Upon hearing of these events, King John sent forces to lift the siege in defense of the clergy, whom he needed to curry the favor of in his struggle against the nobility despite his disregard for clerical pleas for exemption from secular legal jurisdiction (Pearson, 1867, p. 47). 
The nave of the priory church, which survived the dissolution of the monastery, retains another of Norfolk's 30 stone fonts adorned with the Seven Sacraments, featuring the fluctuating eighth panel portraying the baptism of Jesus by St. John the Baptist (Plate 22; Matthew 3.13-17, Mark 1.9-11, Luke 3.21-22). Pevsner (1997, pp. 64, 392) insists that the odd panel is a more unusual depiction of the Trinity, featuring the three consubstantial persons of God in place of the aforementioned figures. This misunderstanding, which may have also been present during the Reformation, arises from the fact that both Christ and the Holy Spirit, present in the shape of a dove, are part of both motifs. While the rolling horizontal lines found in the lower portion of the panel could be interpreted as clouds, supporting a Trinity hypothesis, they are more likely waves representing water, and thus baptism iconography.

Each bowl panel has its basso-relievo severely mutilated, with the heads all showing evidence of having been chiseled flat or enough to obscure the facial features. In many cases, the destruction corresponded with a seam found around the perimeter in the bowl, leaving a clean horizontal break across the entire panel instead of the usual jagged separation at the neck. Despite the fact that the destruction appears indiscriminate, it should be noted that the baptism of Christ panel, depicting events from Scripture, was unusual and caused visual confusion with the Trinity. The beheaded effigy of Christ, in the center of the image, inexplicably has an exaggerated potbelly, a feature in medieval artwork usually associated with demons (Smith, 2012, p. 69 ) or the capital vice of greed (Taylor, 2005, p. 180). This aberration from a traditional visual representation of Christ may have been enough to warrant the wholesale cleansing of all iconography found on the font. The stem is decorated with tracery surrounded eight statuettes of the Apostles, each holding an item that helps in their identification, such as the saltire of St. Andrew or the fish of St. Philip. Each of these carvings, along with eight angels found underneath the bowl and above the stem, all show traces of facial destruction. 

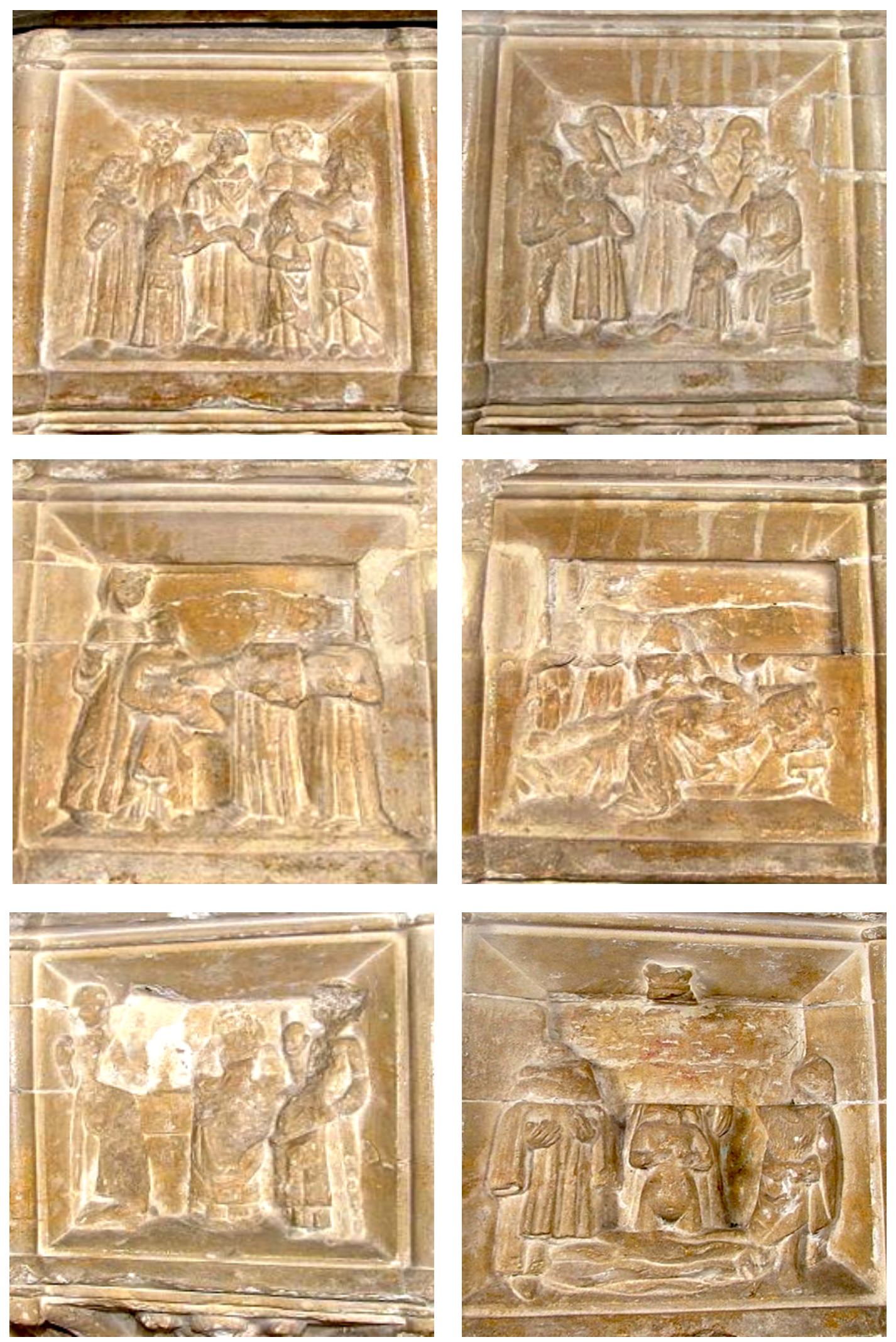

Plate 23: Baptismal Font: Binham 


\section{Case Study: Gayton Thorpe}

St. Mary in Gayton Thorpe also possesses a seven sacraments stone font, albeit without the elaborate tracery on its stem and basin panels found at Binham (Plate 23). This parish church predates the Conquest, as evident from its eleventh-century round-tower construction, and was endowed with 30 acres of property in service of its rather large population. In 1227, a portion of the church's income was granted to the Abbey Church of the Blessed Virgin Mary at West Dereham by Sir Thomas Hastings, whose Sussex family assumed lordship of the sarls of Norfolk by marrying into the line of Roger Bigod (Blomefield, 1808, pp. 437-441). Furthermore, another portion was allotted to Pentney Priory, an Augustinian house located near King's Lynn. These financial arrangements created the common medieval dynamic of a smaller parish church being influenced by a larger monastic institution, until its transference into private secular hands, as was common in the wake of the Dissolution. Landowners of this type had a vested interest in the Reformation, if not on a theological pretext, on economic grounds that would be threatened by a resurgence in Catholicism. The endowment granted to the monasteries by the parish was transferred to their new masters, with the portion earmarked for Pentney now being paid to Thomas Mildmay from Chelmsford in Essex, a royal commissioner for the Dissolution in East Anglia, whose son, Walter, was Chancellor of the Exchequer under Queen Elizabeth I (Blomefield, 1808, p. 439).

The scenes featured on seven of the eight basin panels offered a conventional arrangement of the figures required for the sacraments; however, the panel depicting the sacrament of Ordination features the central figure standing with the descent of a dove, creating a stark contrast with the Penance and Reconciliation panel that portrays the recipient on their knees. These scenes create a greater sense of division between the clergy and laity, as the traditional subservience found in Ordination is replaced with a sense of triumph that is reminiscent of baptism scenes featuring Christ. The eighth panel found on the basin honors the namesake consecration of the church in its depiction of the Blessed Virgin with Child. 

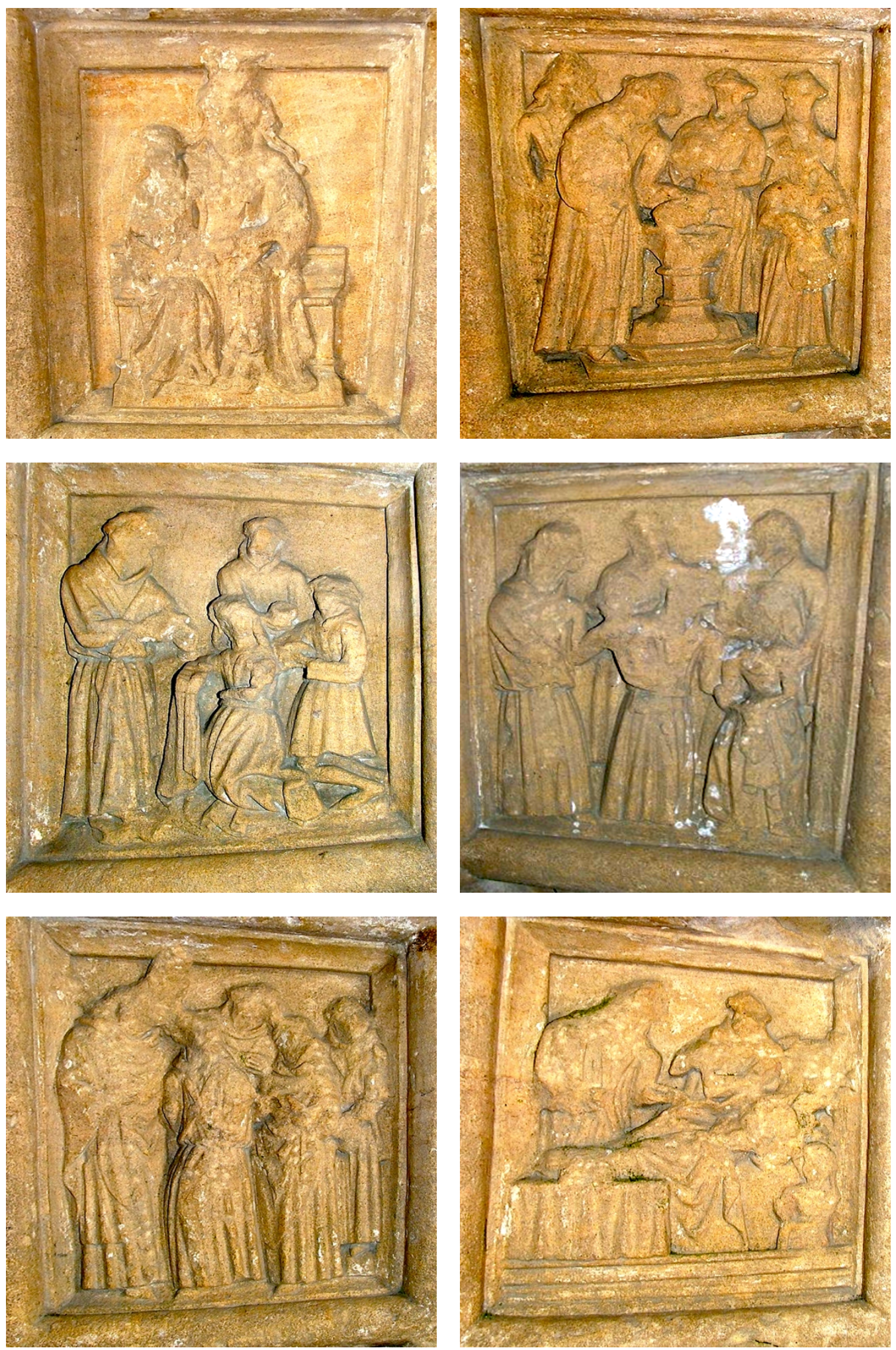

Plate 24: Baptismal Font: Gayton Thorpe 
The iconoclasm found on this particular font is interesting, as every panel features an image with strong ties to Catholic liturgy and veneration. While all seven sacraments show traces of damage, primarily on the figure's faces, the Virgin panel, a common target for reformers, suffered the most destruction with nearly the entire panel being chiseled away. The only image to suffer comparable defacement is the southeast panel depiction of the second sacrament of healing known as Anointing of the Sick, which is the primary component of the Last Rites along with Eucharist and Confession. The role of this sacrament, despite its biblical foundation (James 5.14-15) could have been found as one of those most offensive to the liberal reformers who refused to reconcile the notion that afterlife salvation was entwined with a corrupt temporal agency such as the Church.

\section{Case Study: Docking}

The village of Docking presents another interesting arrangement of authority, as the parish church of St. Mary was subordinate to an alien Benedictine priory for over two centuries (Le Strange, 1973, p. 44). Serving as the manor since its inception in 1209, Docking Priory belonged to Ivry in the diocese of Evreux in Normandy. By the early fifteenth century, institutions of this nature became wildly unpopular leading to their suppression in 1415, the same year as Henry V stunning victory at Agincourt (Page \& Doubleday, 1906, p. 462); Docking Priory was granted to Joan of Navarre, widow of Henry IV. Although the circumstances of this suppression not theological, it is interesting to see this move against a foreign religious institution as a precursor to the disbandment of all monasteries, priories, convents and friaries during the following century.

The same year as the Dissolution, St Mary was able to appropriate the endowment made to the priory, along with five other parishes, to begin construction on an eightyfoot tower, which is the highest point in the entire $R-N W$ sample group. In the same year, William Docking, a rector from Cockley Cley, was buried in the south side of the church and left funds to glaze the windows and aid in the construction of said tower (Blomefield, 1809, pp. 362-370). 
A fifteenth-century font, featuring elaborate late Gothic sculptures, still remains in mostly excellent condition in spite of traces of deliberate mutilation (Plate 24). The tall basin panels provided an ample canvas to produce detailed basso-relievo carvings of the four evangelists and four Latin Doctors (Bond, 1908, p. 247; Whiting, 2010, p. 45), complete with liturgical vestments commonly featured on clerical representations within the Seven Sacraments motif; this is most likely the cause of a common misinterpretation that these figures are merely unnamed church officials (Pevsner \& Wilson, 1997, p. 307). The angled bottom of the basin is decorated with the evangelists symbols beneath the appropriate panel, and a rose beneath the Doctors and eight angels on each joint. The ornamentation continues around the lower perimeter of the stem with eight female figures, all missing their heads. Three of these figures are holding infants, which easily identifies them as the Virgin, St. Anne and St. Elizabeth holding Christ, the Virgin, and John the Baptist respectively. The paraphernalia in the figure's hands can identify the remaining five: St. Apollonia with pincers; St. Catherine with a wheel and sword; St. Margaret with a spear and dragon (Collins, 1914, p. 182); St Dorothy or Apollonia with pincers; and St. Agatha or Sitha holding forceps, which may or may not actually be a key ring (Nichols, 2002, p. 228). This attack on female images suggests a trend, as six of the figures are extra-Biblical, with the additional two tied up with Marian bias.
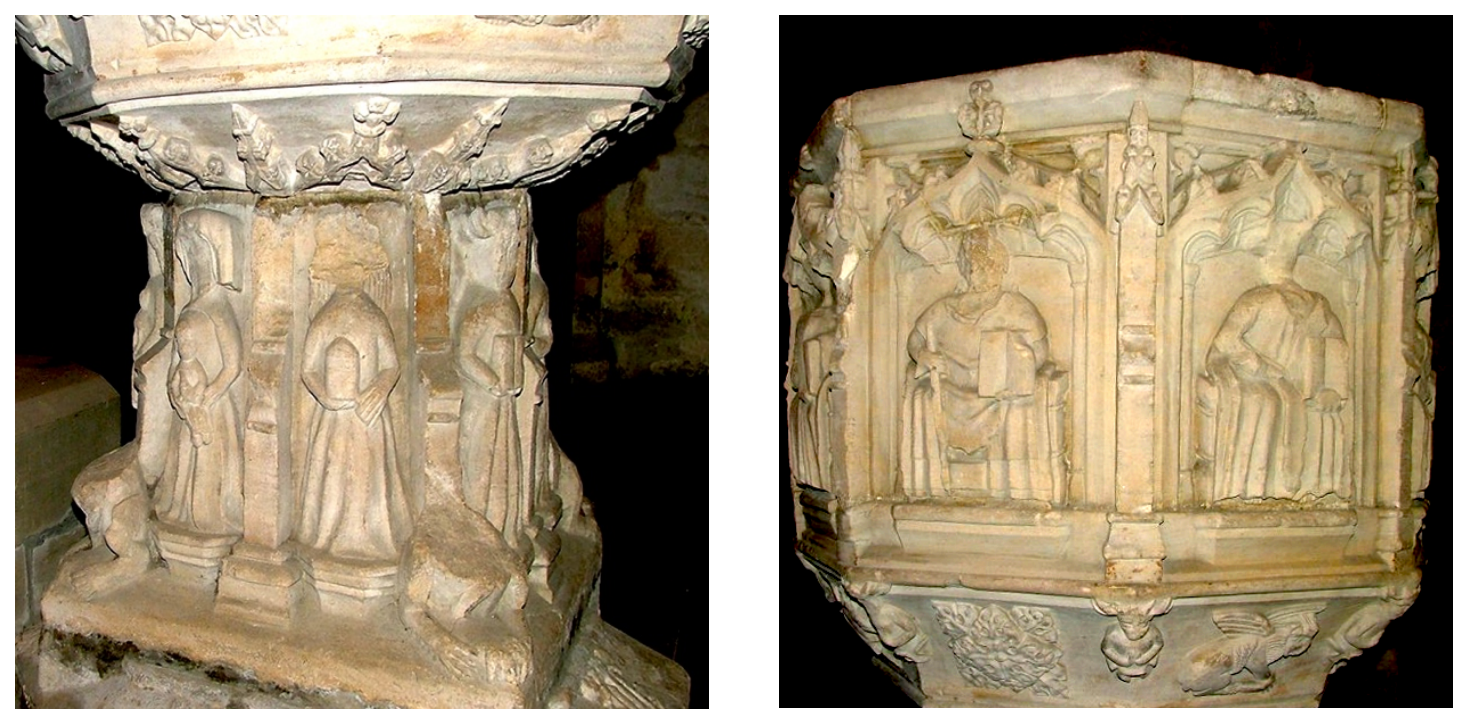

Plate 25: Baptismal Font: Docking 


\section{R-NE Sample}

This section examines two defaced stone fonts located at Burgh-next-Aylsham and Colby. While the former provides insight into which sacraments were more offensive to iconoclasts, the latter demonstrates the strong bias against extra-biblical figurative decoration, specifically Marian icons.

\section{Case Study: Burgh-next-Aylsham}

The medieval parish of Burgh-next-Aylsham, today united with Tuttington, has an early thirteenth-century church on the banks of the River Bure consecrated to St. Mary. Of the original Early English Gothic (1189-1307) construction, only a truncated version of the chancel has endured a fifteenth-century renovation of the nave and a sixteenthcentury roof refurbishing. In 1459, William Norwich granted the church a sizable endowment for the construction of a new square bell tower topped with battlements (Cattermole \& Cotton, 1981-83, p. 264). This project sparked a beautification campaign that saw the commissioning of a new baptismal font decorated with the seven sacraments motif, the hallmark of East Anglian stonemasons, set atop a Maltese cross with the signs of the evangelists in each corner (Plate 25). The intricacies of the carvings are relatively modest in detail, compared to the fonts found at Binham and Docking; however, a unique eighth panel can be viewed on the southeast side of the bowl. This low relief is of a man kneeling before a vested altar holding what appears to be a chalice, although the exact nature of the object between the figures folded hands is difficult to decipher due to damage (James, 1930, p. 159). The molestation of this carving extends to the kneeling man's face and what seems to be a small figure set atop the altar, an image that suggests this panel is a representation of the Mass of Saint Gregory. This iconography illustrates a Catholic account of Pope Saint Gregory I receiving a vision of Christ at the altar during communion as a divine validation of the transubstantiation. The form taken by Christ in most representations of the story is as the Man of Sorrow, or Suffering Servant as described in Jewish scripture (Isaiah 53) and in all Passion accounts found within the Gospel. The first revision made to the Book of Common Prayer, published in the fifth year of Edward VI's reign, pushed the theological underpinning of the Church of England into a distinctly Protestant direction with its position regarding the nature of the Eucharistic sacrament. Rather than a miraculous transformation, communion was perceived as a symbolic act of 
remembrance since "the naturall body and blood of our saviour Christ, they are in heaven and not here. For it is agaynst the trueth of Christes true natural bodye, to be in moe places then in one, at one tyme" (Church of England, 1825, p. 667). This shift in doctrine left the Mass of Saint Gregory as an especially offensive representation in its divine glorification of a denounced component of liturgy.

The theme put forth in the Mass of St. Gregory panels, of the divine authority linked to the sacraments, is continued in a heavily defaced image depicting the Sacrament of Penance and Reconciliation. This scene, featuring a parishioner confessing his sins, includes a demonic figure fleeing into the backdrop; the implication being the absolution of one's sins through the Church has averted condemnation and the fire of Hell. Conservative Anglicans could abide this rite, as the common position in regards to confession became "all may, some should, none must"; however, this was at odds with the reforming principle of sola gratia, or by grace alone.

English iconoclasm is often difficult to date with a chronological window of over a century existing for potential periods of destruction. In the case of Burgh, a more conservative presence existed in the parish on the eve of the armed conflict between Charles I and Parliament. This parish was spared an aristocratic influence throughout the Reformation, as the sixteenth and seventeenth century saw a lapse in occupancy by any gentry (Blomefield, 1807, pp. 427-430). This may have resulted in a community entitled to greater flexibility in their expression of faith that appears to have shifted conservative by the mid-seventeenth century. In 1640, a Grand Committee of Religion was formed to investigate the state of all parishes, in regards to decay of preaching, increased popery, and scandalous ministers (Shaw, 1900, p. 15). The rector of St. Mary, Nathaniel Gill, who had received his training at Trinity College, Oxford, was promoting a conservative theology that seemed at odds with Puritanism. By August 1643, the Long Parliament passed the Ordinance for sequestering notorious Delinquents' Estates, which targeted even marginally defiant clergy like Gill. In the wake of having his lands seized, he was recorded in the parish register boasting of his adherence to High Church Anglicanism as he baptized infants with the sign of the cross and performed burial rituals in accord with the prayer book before retiring from his duties at Burgh in 1651. He returned as vicar at Aylsham three years into the Restoration (Yates, 1884, pp. 46-47). 

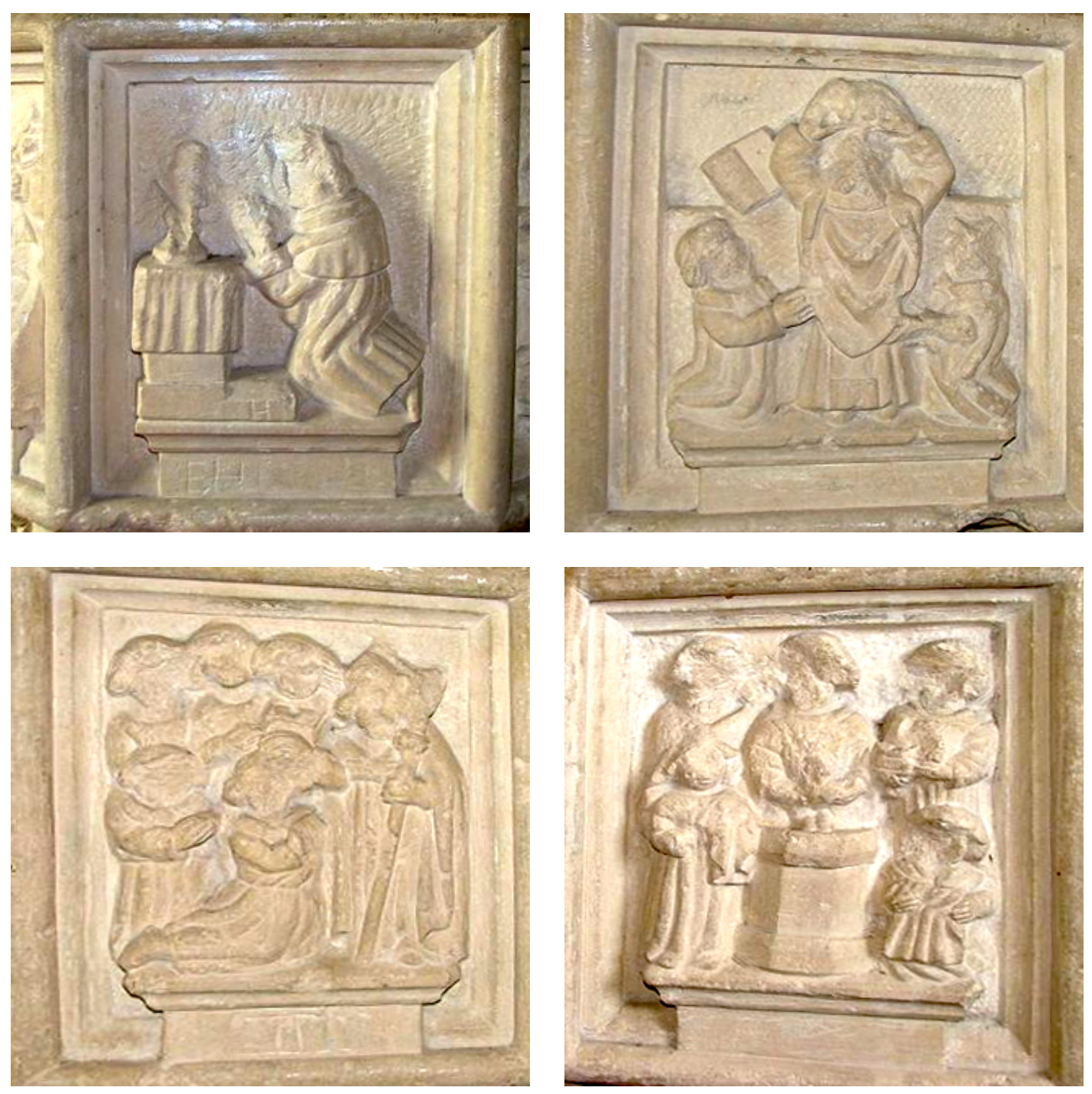

Plate 26: Baptismal Font: Burgh-next-Aylsham 


\section{Case Study: Colby}

To the north of Burgh, past Banningham, lies the village of Colby and its church dedicated to St. Giles, whose finger was allegedly retained as a relic in a silver reliquary. The laity of this parish had four confraternities, with one named for the church's namesake, one for St. John the Baptist and two for the Blessed Virgin (Blomefield, 1807, p. 423). The town itself began as a corn farm under the dominion of Cawston until it was divided between the local Colbi family and the earls of Norfolk, which led to the manor being passed to a series of families, such as the Howards and Windhams, and joined with other estates as near as Ingworth or as far as Felbrigg, Cromer and Hanworth near London.

The religious inclination of this parish during the Reformation is unclear beyond what can be assumed was a severe upheaval following the dissolution of the four guilds after 1547, a result of policies put forth by the Edwardian regime. In the subsequent years, the inventory of the church, compiled by royal commissioners, does not mention the enforcement of any policies against images or liturgy outside the reference of the sale of silver cross, the funds being used for repairs. This nominal reference had to be submitted by the churchwardens, as it was required that notice be provided to the commissioners of the sale of any church goods before their seizure (Rye, 1872, p. 25).

A late fifteenth-century stone font in the Perpendicular Gothic style has survived in situ as evidenced by its octagonal pedestal, which is in perfect alignment with the bowl (Plate 26). In a rare case of spatial positioning, not one of the eight panels face east directly; instead, corners point directly north, south, east, and west. In regards to this unusual placement, it is possible that a notion of having two panels facing the altar may have influenced the placement in an attempt to combine equal tribute to both instances of iconography. While the northern east panel features the Virgin and Child, the southern east panel features two kneeling figures that appear to the donors. The intention of such placement may have been instigated by the benefactors themselves, in order share in the sacred positioning alongside a prominent religious icon.

The Virgin panel is presented as sedes sapientiae, or upon her throne of wisdom with a crown of majesty on her head and Christ sitting on her lap. The throne of wisdom 
itself, which is presented more as a wide bench, draws its inspirations from a biblical account of Solomon (I Kings 10.18-20, II Chronicles 9.17-19) with the addition of Mary stemming from earlier Byzantine art presenting the Virgin as the "container of the uncontainable God" (Peltomaa, 2001, pp. 76, 94). This motif was very common in work produced by the Flemish Primitives in the fifteenth and sixteenth century (Barasch, 1997, pp. 83-84), a style to which the region was exposed as a result of Norfolk's prosperous wool trade with the Low Countries.

The panel to the right of the Seat of Wisdom features a carving of a huntsman, brandishing an axe and kneeling before a small four-legged creature that appears to be a canine. Although it has been inferred that this image is of St. Giles protecting a deer (Mortlock \& Roberts, 2007, pp. 70-71), the content of this damaged panel correlates closer to St Edmund; patron saint of pandemics, kings, and the entire East Anglian diocese (Ball, 2003, p. 276; Ridyard, 2008, pp. 211-233). Edmund ruled East Anglia in the mid-ninth century until his defeat and death on the battlefield while facing an invasion of Danes around 855. Within a century, a Benedictine monk from Ramsey Abbey commissioned Abbo of Fleury to compose Passio Sancti Eadmundi, which presented the conflict as martyrdom for the fallen monarch (Pestell, 2004, p. 110). The story continued to evolve to include an elaborate backstory that began with the wayward shipwreck of a noble Dane on the shores of Norfolk. After being brought before the East Anglian king, the Dane impressed Edmund with his extensive skill as a hunter. The royal huntsman became overcome by jealousy for the shift in the king's affection and murdered the Dane. Upon discovering what had transpired, Edmund sought to punish his huntsman by setting him adrift on the same boat the Dane has previously arrived on. This act set into a motion a chain of events that proved to be the king's undoing, as the boat found its way back to the home of the Danes. Upon being captured, the royal huntsman told the Dane's sons that King Edmund had killed their father, which sparked the subsequent invasion (Waters, 1886, pp. 100-101). Iconography of this nature combines regional history and religious tradition with a wider sense of xenophobia; a notion that could have resonated with parishioners of a small village caught up foreign influence stemming from overseas commerce. 
The mild damage to the font includes facial features chiseled off, in the case of the Virgin, donors and huntsman panels, with signs of cement covering the basso-relievo on the remaining panels; four relatively unmolested panels featuring signs of evangelists, with the exception of the humanoid effigy for Matthew, and a blank panel which may have been cemented over during the Reformation. The images found on this font, both damaged and surviving, do help provide context for a parish lacking an abundance of documentary evidence; however, the village does appear to have had a conservative sense of religion, shaped by aristocratic and fraternal influences, on the eve of reform.
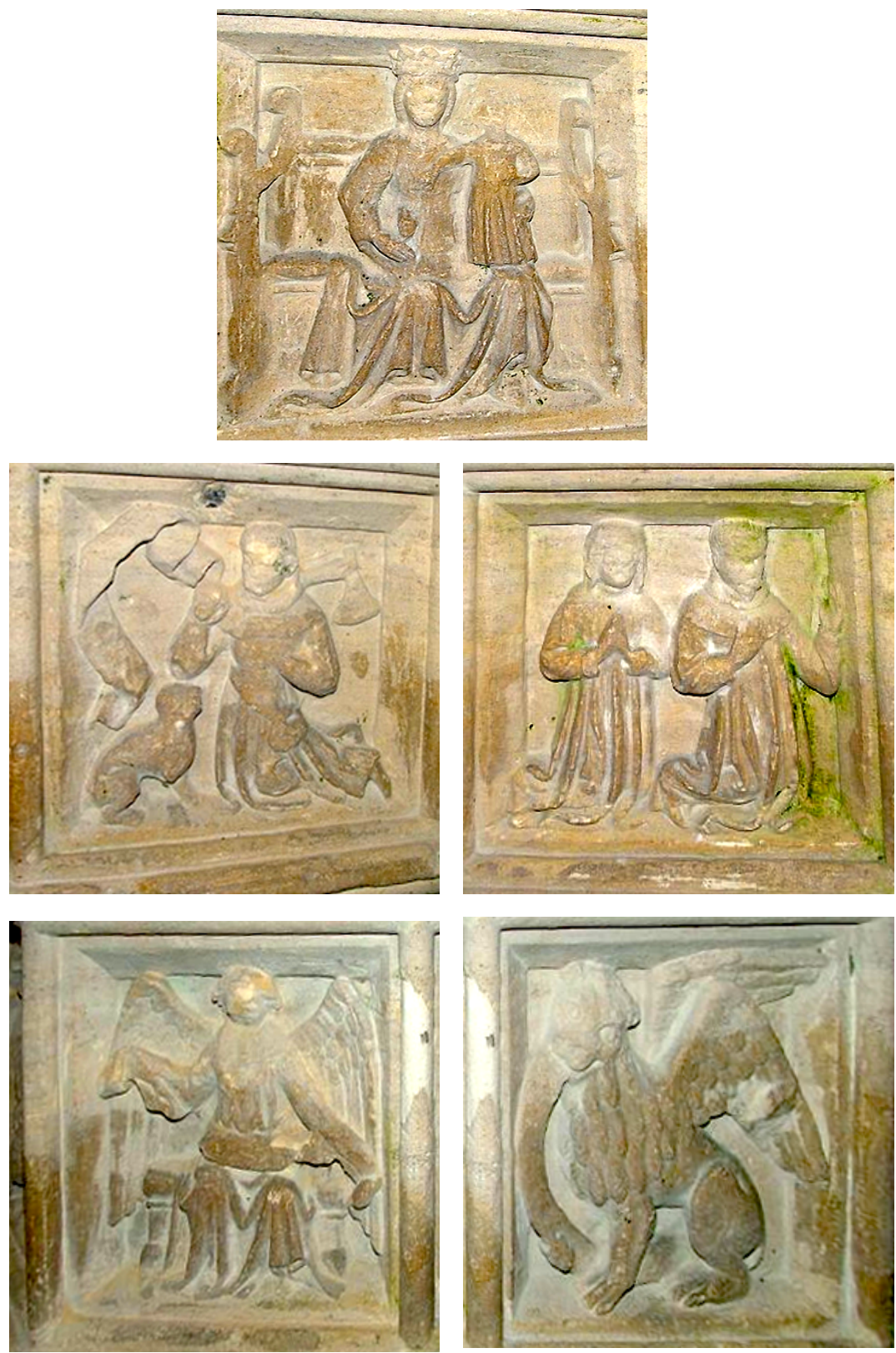

Plate 27: Baptismal Font: Colby 


\section{R-S Sample}

Only the parish of Bridgham was selected, as this sample group featured the lowest totals of biblical or extra-biblical iconography. However, this group also boasts the highest totals of secular or decorative features, which were more prone to survive undamaged.

\section{Case Study: Bridgham}

The small parish of Bridgham suffered massive upheaval resulting from Tudor rule including, and beyond, the consequences of religious reform. Despite its diminutive size and rural setting, the village had a constant influx of visitors traveling from Suffolk on a pilgrimage to the Shrine of Our Lady of Walsingham. This dynamic must have shaped the structure of the local economy, which possessed the opportunity to generate revenue outside of agriculture. Furthermore, the rectory did not provide any funds to the Crown, an unusual arrangement for a parish church, until the reign of Henry VIII (Armstrong, 1781, p. 58).

The rectory, with a church dedicated to St. Mary, had a long history of being influenced by external religious forces. This benefice was bound to Hackford's manor and under the dominion of the Benedictine abbots of Ely until the order was superseded by a new episcopate establishment in conjunction with the completion of the new cathedral in the early twelfth century (Blomefield, 1805, pp. 436-440). This alignment of power endured until 1558 when Bridgham, along with Brettenham, was taken from the bishop and transferred to the Crown, in the person of Elizabeth I, although the manor and rectory were in the twelfth year of a sixty-year lease. The conclusion of the arrangement finally culminated in the official transference of authority from James I to one Framlingham Gaudy, a member of the middling gentry (Armstrong, 1781, pp. 56$57)$.

St. Mary has a fifteenth-century stone font, which retains sporadic vestiges of its original paintwork, either eroded through time or partially preserved by Reformationera whitewashing; the latter is more likely as the fitting has a chalky white appearance (Plate 27). The bowl is adorned with an intriguing mix of religious iconography and ecclesiastical heraldry, reflecting the medieval alignment of power in the parish. The 
panel facing the altar depicts the Holy Trinity, with God the Father seated behind the crucifixion. While most accounts describe this image as the Holy Trinity lacking the third consubstantial expression of the Holy Spirit, often depicted as a dove, this defaced iconography is more evocative of the Throne of Mercy motif or even the rare Bosom of Abraham Trinity. In either case, this representation features the crowned Father seated behind the crucified Son, with the differences being the Throne motif having a space reserved for the dove of the Holy Spirit and the Bosom motif having the Father holding a cloth filled with souls. This panel features heavy damage to the faces of both figures, thus making it impossible to determine which motif this image was intended to be. The Bosom of Abraham Trinity, also known as the Trinity with Soul, is one of the most elusive icons in England, with only twelve known survivals (Barratt, 2008, p. 51; Ramsay, 1987, pp. 514-515). To the immediate left of this panel is an angel holding the Shield of the Trinity; which is a common trend across the remaining panels which group a figure with their respective heraldry.

The southern and northern facing panels both feature the figures of clergymen, most likely seated bishops from their vestments. These two figures, with mutilated faces, can be inferred to be the bishop of Ely and the archbishop of Canterbury, respectively. The juxtaposed panels to these two images feature vandalized angels holding the heraldic emblems of the episcopacy of Ely (Blomefield, 1805, p. 439), which held control of the parish when the font was commissioned, and the archiepiscopacy of Canterbury. This direct implementation of local ecclesiastical authority on a fitting as crucial as a baptismal font helps develop an understanding of how independent this parish was from secular authority.

The final note of importance regarding this font is the damaged survival on the western panel of the Assumption of Mary, one of the primary renditions of the Virgin deemed offensive and blasphemous in the wake of the scriptural-based theology emerging during the Reformation. The notion that Mary bodily ascended into Heaven at the conclusion of her mortal life is not told in Scripture, and places the mother of Christ on a spiritual level comparable to her Son. While the Incarnation was derived from Scripture (Matthew 1.18-23, Luke 1.34, John 1.14), the devotional abuses which presented Mary as “Mediatrix', or mediator, with Christ, were rejected by reformers. 
These popular misuses of Marian theology conflicted with official Catholic doctrine and extended into the Reformation, rendering the Virgin a particular offensive icon. Despite this, her biblical prominence led to her being referenced as a 'pure virgin' from the 1552 revision of the Book of Common Prayer (Christmas Daie Collect) and even the retention and alteration of the five feast days discussed previously.

Despite backlash again Marian iconography, this panel has not suffered the level of aggressive damage that the previous examples, like Gayton Thorpe, possess.

Iconoclastic restraint is demonstrated, as only the faces of the Virgin, angels and saints were targeted. The reasons for this level of restraint is intriguing, as it helps reveal a parish adjusting to vast changes brought about directly and indirectly by the Reformation.
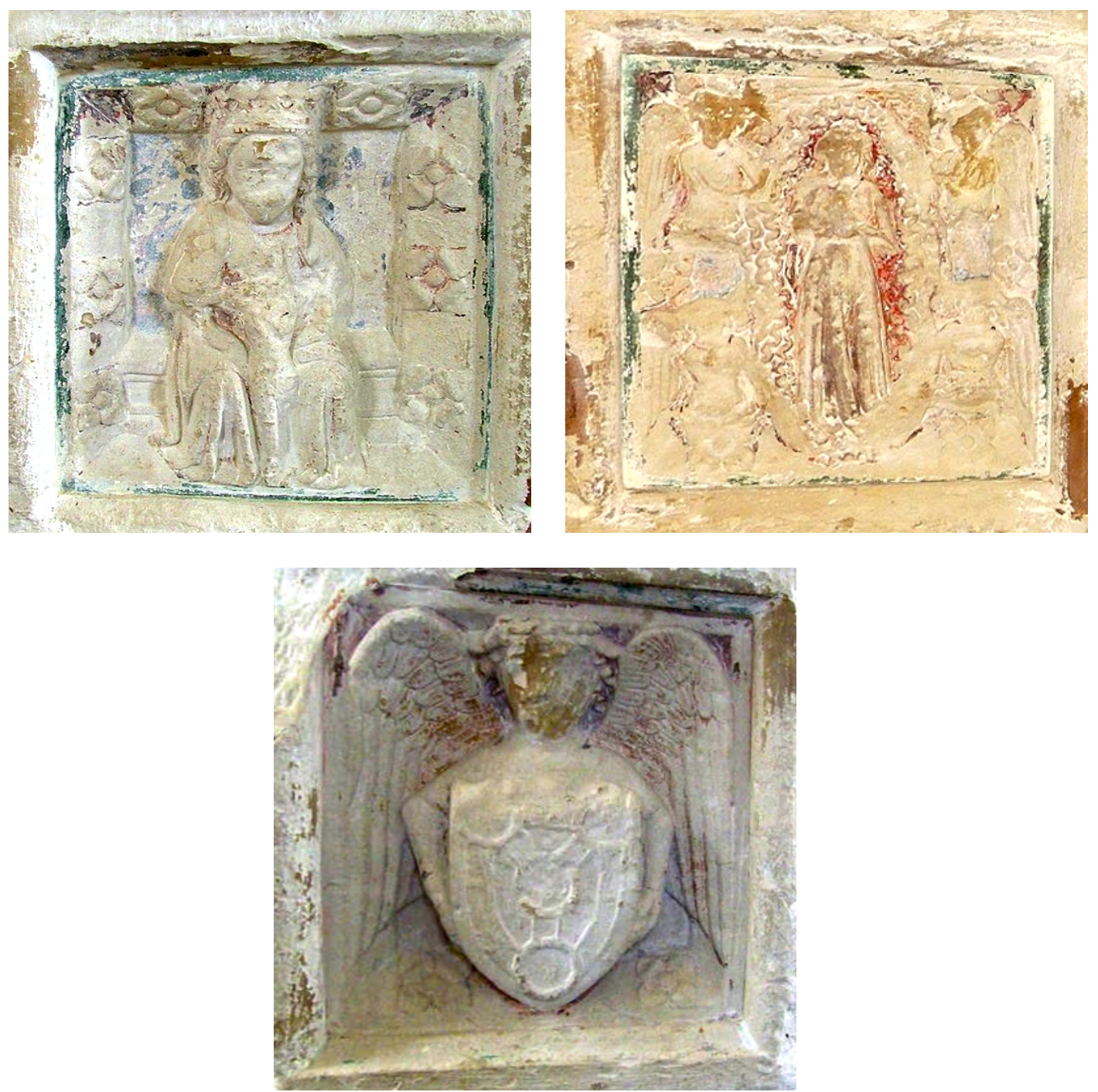

Plate 28: Baptismal Font: Bridgham 


\section{U-N Sample}

\section{Case Study: Norwich: St. Mary in the Marsh}

One of the most prominent medieval churches in Norwich was St. Mary in the Marsh, a parish located within the boundaries of the cathedral close. This building predated the cathedral itself, as it was commissioned by Herbert de Losinga, bishop of Thetford at the time, along with St. Margaret at King's Lynn and St. Nicholas at Yarmouth in the late eleventh-century. It may have been Losinga's experience with the construction of this church which inspired the building of the cathedral following the papal allowance to move the diocesan seat to Norwich. The resulting geographic realignment of ecclesiastical authority in the county left St. Mary in the Marsh as one of only two parish churches within the jurisdiction of the Close along with St. Helen (Britton, 1816, p. 29; Browne, 1814, pp. 258-259). The result must have been a very formal establishment with immense influence flowing from both the episcopacy and the Benedictine priory operating at the Cathedral. In the wake of Tudor reforms, and the surrender and conversion of the priory into a secular order, St. Mary in the Marsh was deemed redundant in the face of a shift from devotional to congregational worship. In 1564, it was formally closed, gutted, and converted into dwelling houses (Groves, 2010, p. 146). While the original plan was to consolidate the parish, along with St. Vedast, into St. Peter Parmentergate, the parish was installed at Jesus Chapel within the Cathedral itself, an apsidal room off the north aisle. This section of the Cathedral, featuring its own eastern facing altar, was once dedicated to the Holy Martyrs and contained the tomb of William of Norwich (Gilchrist, 2005, p. 249). It is ironic that the parishioners of St. Mary in the Marsh, martyrs in their own right as a result of the Reformation, would be relocated here.

The congregation was relocated to different locations throughout the cathedral, until they were finally installed in St. Luke's chapel, along with their ornate baptismal font (Plate 28-29). The fact that this fixture was not only spared, but also moved to a new location of worship, is a powerful testament to how important baptism still was. Moreover, it demonstrates the object's significance to parish and community identity. The font was a fifteenth-century East Anglian piece (Pevsner \& Wilson, 1997, p. 208), in the common medieval octagonal style. Each panel depicts one of the seven 
sacraments; the eighth panel was reserved as was common for the Crucifixion. The base features eight seated figures on each corner, with eight additional standing figures on each side of the pedestal. While identifying these vandalized figures is difficult, it has been suggested that were the four evangelists with an assortment of twelve saints, popes, and confessors (Blomefield, 1806, p. 9). Every single carving on this font has been severely mutilated; while most figures are missing their heads, others have been completely removed. The rich stonework found on this font, combined with its strong Catholic iconography, must have made it an unbearable sight in the face of reformers seeking to cleanse all things considered to 'popish.' While it is unclear when this demolition took place, there are two possible candidates. First, the font may have been defaced during its initial relocation in 1564 under the auspices of Bishop Parkhurst, an Elizabethan appointee who had spent an extended period of time in Geneva, no doubt consuming continental Protestant theology, during the Marian interlude. The second opportunity may have occurred in the following century when the Cathedral was ransacked by a 'rabble' of Puritans, as recorded by Bishop James Goldwell in 1643. The latter stripped the Cathedral of many of the last vestiges of portable medieval iconography, as all images, vestments, statues; organ pipes and a plethora of books were brought to the marketplace for burning (Hall \& Pratt, 1808, p. 1xvi; Anon., 1855, p. 16). 

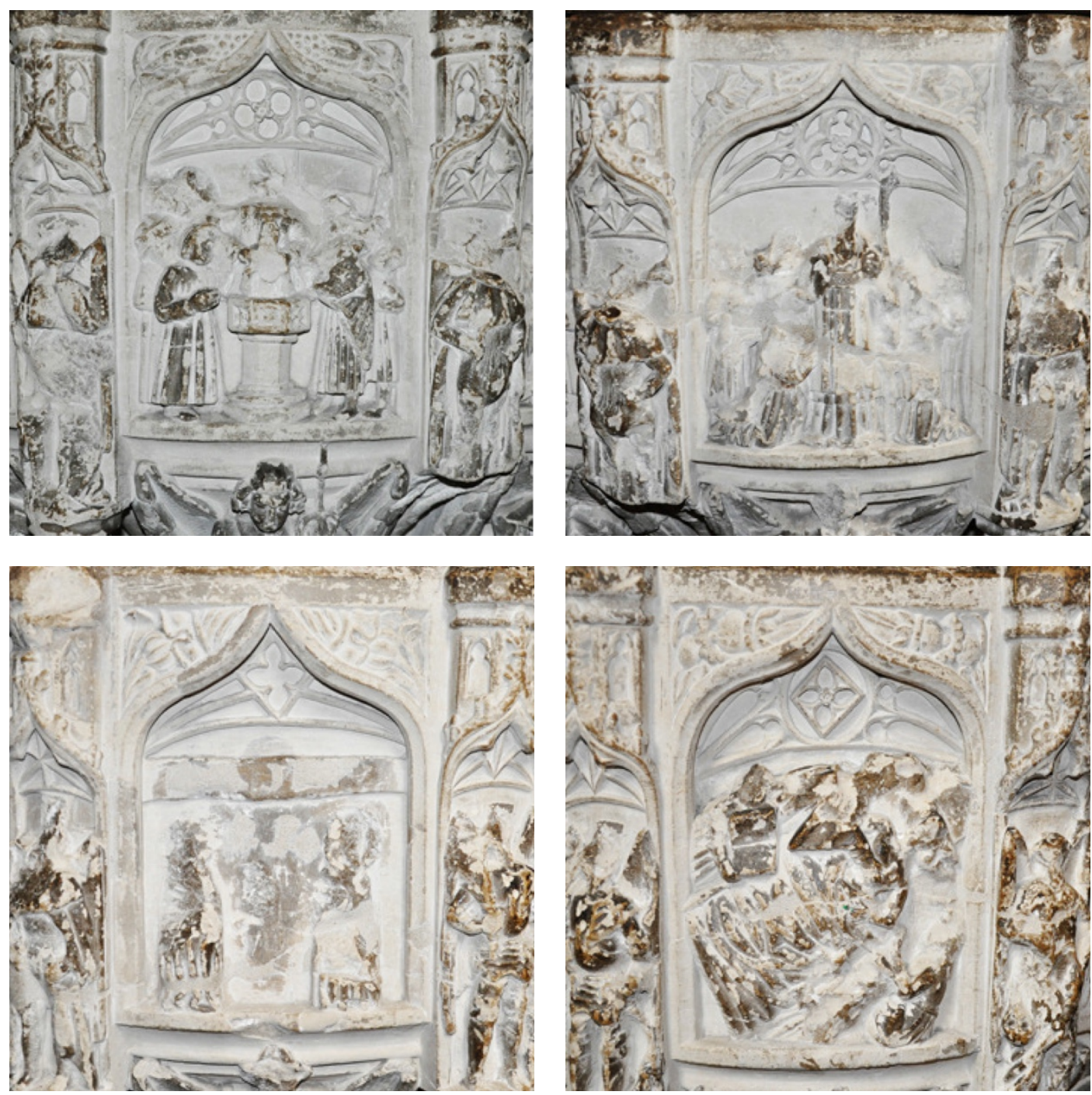

Plate 29: Baptismal Font: St Mary in the Marsh. Part One 

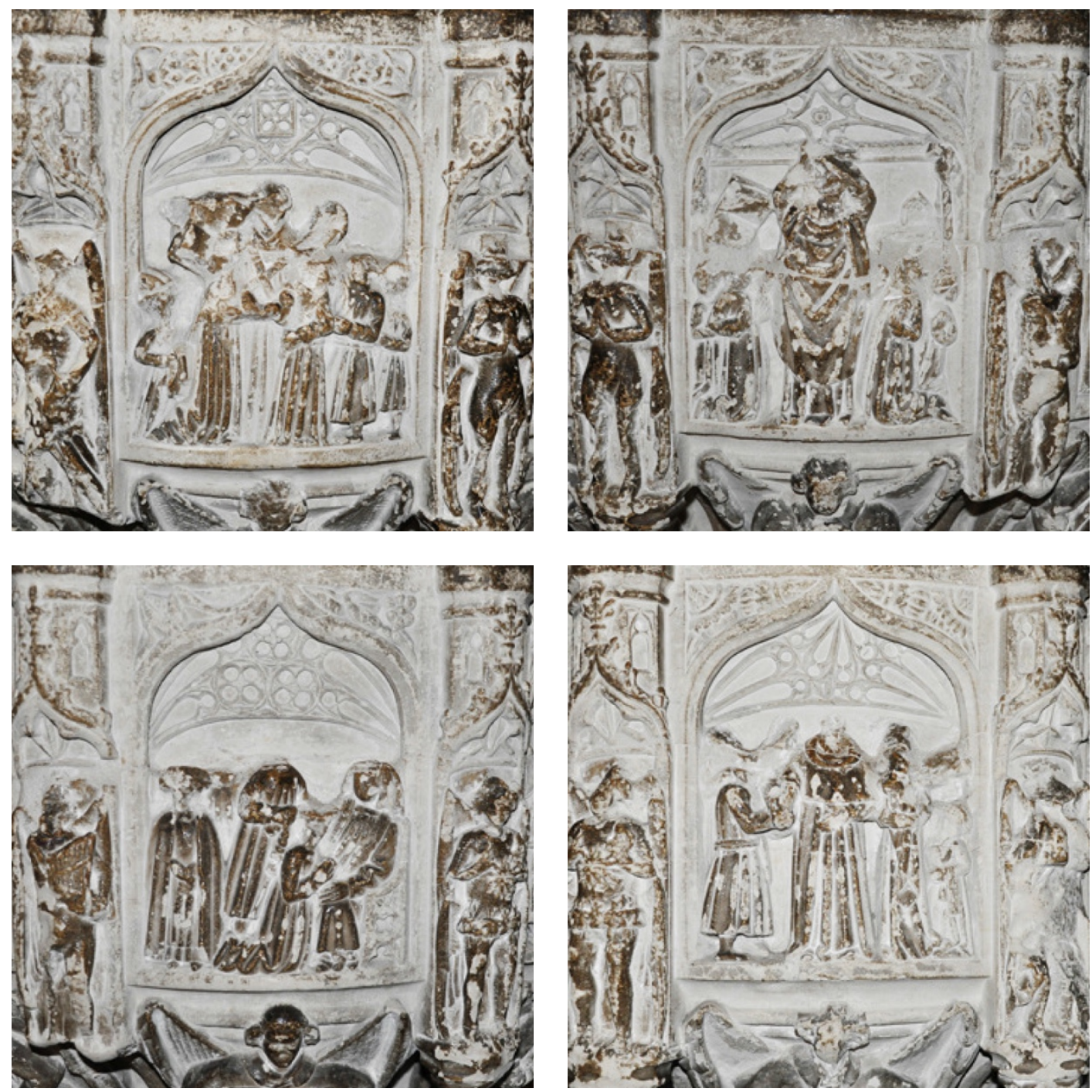

Plate 30: Baptismal Font: St Mary in the Marsh. Part Two 


\section{Case Study: Norwich: St. Peter Mancroft}

St. Peter Mancroft, the largest parish church in Norwich, faced a shift in authority and increased in influence as a result of the Reformation, specifically the Dissolution of the Monasteries. Following the Conquest, the church found itself under the neglected control of the Benedictine monastery of Gloucester Abbey for nearly three centuries. By 1388, the growth of wealth and prosperity in Norwich prompted ownership to be transferred to the local community of St Mary-in-the-Fields, another Benedictineowned house. The dean and chapter of the college did not see fit to appoint a rector or vicar and instead chose to retain all revenue themselves for the grand rebuilding of the church (Blomefield, 1806, pp. 184-238). Along with contributions from affluent citizens, merchants and craft guilds, St. Peter Mancroft was consecrated by 1455 . Within a century of its emergence, this parish church suffered massive upheaval as a result of the Henrician reforms. The patron college of St Mary-in-the-Fields was closed in 1544, with the greater tithes, such as corn, hay, and wood, being transferred to a series of families; the vicar retained a smaller portion of the tithes. Without the monastic provisions, the citizens of Norwich began to rely far more on their parish churches for civic and charitable support. In 1581, the parishioners themselves attained the patronage of the church and appointed members of the laity to act as trustees (Blomefield, 1806, pp. 184-238). This arrangement, of a prominent parish church controlled by the people, was a very progressive notion complete with the appointment of the vicar, or parish priest, by the laity themselves.

A seven-sacrament stone font was bequeathed to the church in 1463 by a wealthy grocer from the neighboring marketplace named John Crawston (Plate 30; Pevsner \& Wilson, 1997, p. 249). The octagonal basin was decorated with painted sacrament iconography, as opposed to the carved reliefs found on the St Mary in the Marsh font at Norwich Cathedral. The shafted stem was adorned with eight carved figures of saints. It appears that the figurative decoration was spared the early waves of iconoclasm during the Edwardian reforms. In 1642-43, the parish church allotted funds to take down idols and replace glass formally. This included 'the takeing down images at the font' (Spraggon, 2003, p. 110). As a result, the eight figurative carvings on the stem were hacked off and the painted exterior whitewashed. It is important to note that these removed images may not be medieval, as it is possible that they were added during the 
campaign of beautification in the 1620s; another reminder of the difficulty associated with dating iconoclasm. The font was utilized for the next two centuries until it was discarded during the Victorian refitting of the 1880s. In 1926, it was rescued, cleaned, and restored to the baptistery. Faint traces of the original paint were actually preserved, as a result of the Puritan whitewash (Riddle, 1960, p. 10).
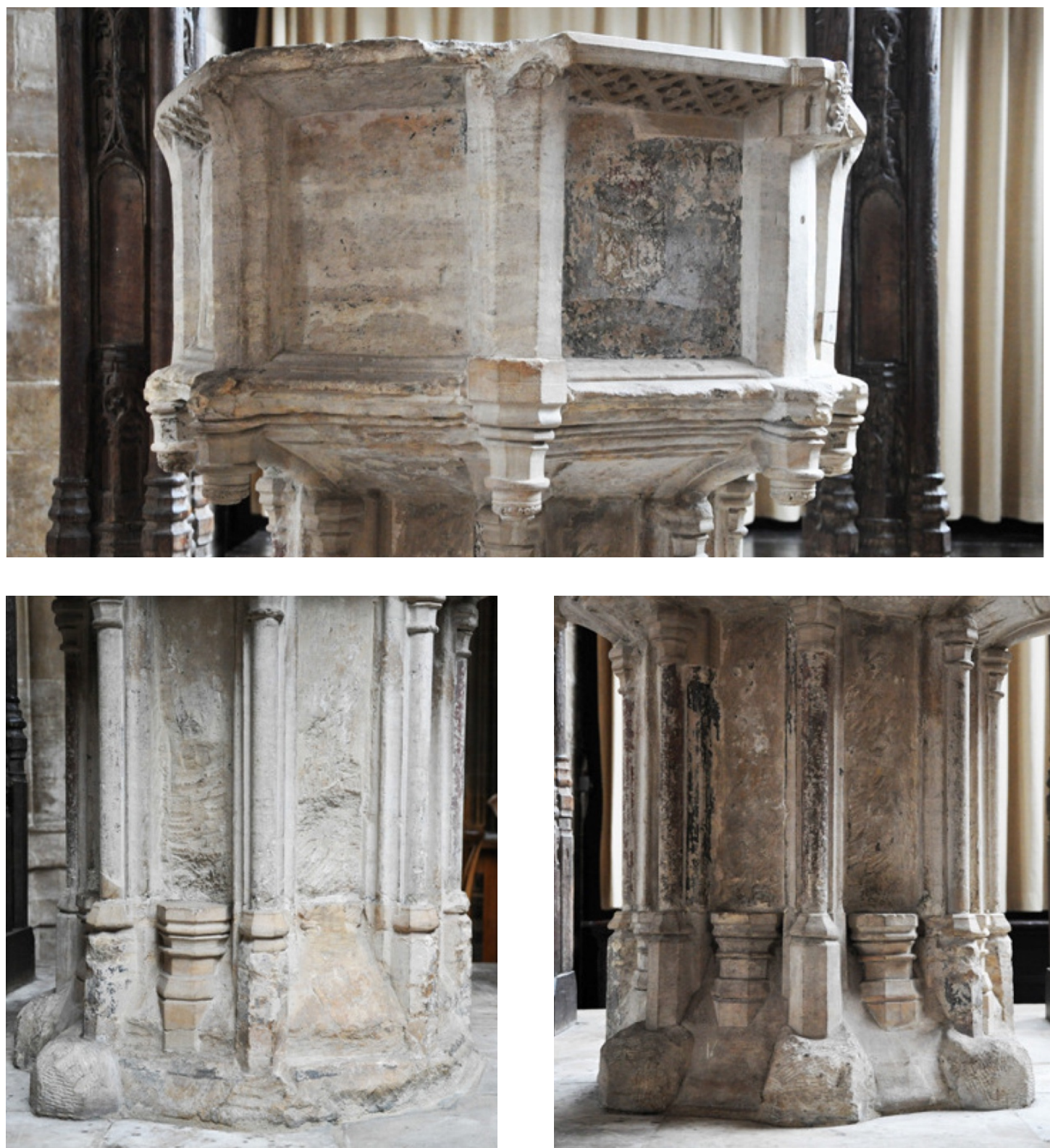

Plate 31: Baptismal Font: St Peter Mancroft 


\subsection{Screens}

Chancel screens were one of the most visually prominent fittings installed within a medieval church and were a testament to both the religious inclinations and the secular heritage of a parish. The sheer scale and position of these partitions rendered them part of the architectural fabric of the building itself, leaving it very challenging to ignore any images chosen for their adornment. The vulnerability of this constant exposure was compounded by the destructible nature of polychrome depictions set upon wood, and often carved, panels. The spike in screen construction seen during the late Perpendicular Gothic period correlated with the economic boom in Norfolk, which resulted in the renovation and expansion of churches across every sample group (Pevsner \& Wilson, 1999, p. 24). A new screen was often the final touch needed to cap off an extensive building project, placing many of their constructions or decorations on the eve of the Reformation. Unlike baptismal fonts, these fittings would have been completed later in the renovation process, as they were not quite as integral to the liturgy. This provided a grand opportunity for a wealthy parishioner to demonstrate the prominence of their family by commissioning a panel, a series of panels, or the screen itself. As the erection of these screens was still in recent memory, the connection between a fitting and the benefactor during the sixteenth century also needs to be considered when considering any iconoclastic damage incurred. As the aristocracy and affluent merchants poured their riches into these massive building projects, the political upheaval and civil warfare of the fifteenth century (Wars of the Roses) was a further economic drain. This tenuous financial situation must have curbed these benefactors' ability to patronize Italian artists, resulting in the use of local craftsmen and to the emergence and prosperous growth of the Norfolk school of artwork (King, 2013, p. 92).

The continued necessity to separate the chancel from the nave, as the liturgical implications were still evolving, can be attributed to the widespread survival rate. The use of figurative artwork, usually sans any Christological depictions, allows a precise analysis of which saints were targeted for defacement. The rate of destruction of images derived from sources outside of the Bible is again at a significantly higher rate than their scriptural counterparts or neutral decorative motifs across all four samples. Several trends emerge from an analysis of these datasets, such as the severity of 
damage inflicted on extra-biblical figures in the $R-N W$ sample. Moreover, the harm done to neutral subject matters is more than double in the $R-N E$ sample than the $R-N W$; while the $R-S$ sample has the same amount of neutral features as the other three samples combined, without a trace of any significant damage. The $R-S$ sample also features a lower overall rate of iconoclasm in all three categories; with the exception of Norwich, which only features five screens and does not lend itself to quantity rate analysis. 


\begin{tabular}{|c|c|c|c|c|}
\hline & & Icons & Damaged & Rate \\
\hline & & (i) & (d) & $(d / i)$ \\
\hline \multirow[t]{6}{*}{ R-NW } & Brothercross & 4 & 3 & $75 \%$ \\
\hline & Freebridge-Lynn & 8 & 3 & $38 \%$ \\
\hline & North Greenhoe & 11 & 8 & $73 \%$ \\
\hline & Smithdon & 3 & 2 & $67 \%$ \\
\hline & King's Lynn & 0 & 0 & $0 \%$ \\
\hline & TOTAL & 26 & 16 & $62 \%$ \\
\hline \multirow[t]{5}{*}{ R-NE } & Blofield & 22 & 19 & $86 \%$ \\
\hline & South Erpingham & 20 & 16 & $80 \%$ \\
\hline & Taverham & 4 & 3 & $75 \%$ \\
\hline & Tunstead & 17 & 7 & $41 \%$ \\
\hline & TOTAL & 63 & 45 & $71 \%$ \\
\hline \multirow[t]{5}{*}{$\mathbf{R}-\mathbf{S}$} & Depwade & 10 & 4 & $40 \%$ \\
\hline & Diss & 5 & 0 & $0 \%$ \\
\hline & Guiltcross & 5 & 3 & $60 \%$ \\
\hline & Shropham & 10 & 0 & $0 \%$ \\
\hline & TOTAL & 30 & 7 & $23 \%$ \\
\hline $\mathbf{U}-\mathbf{N}$ & Norwich & 9 & 2 & $22 \%$ \\
\hline TOTAL & & 128 & 70 & $55 \%$ \\
\hline
\end{tabular}

Table 15: Screens: Iconoclasm 


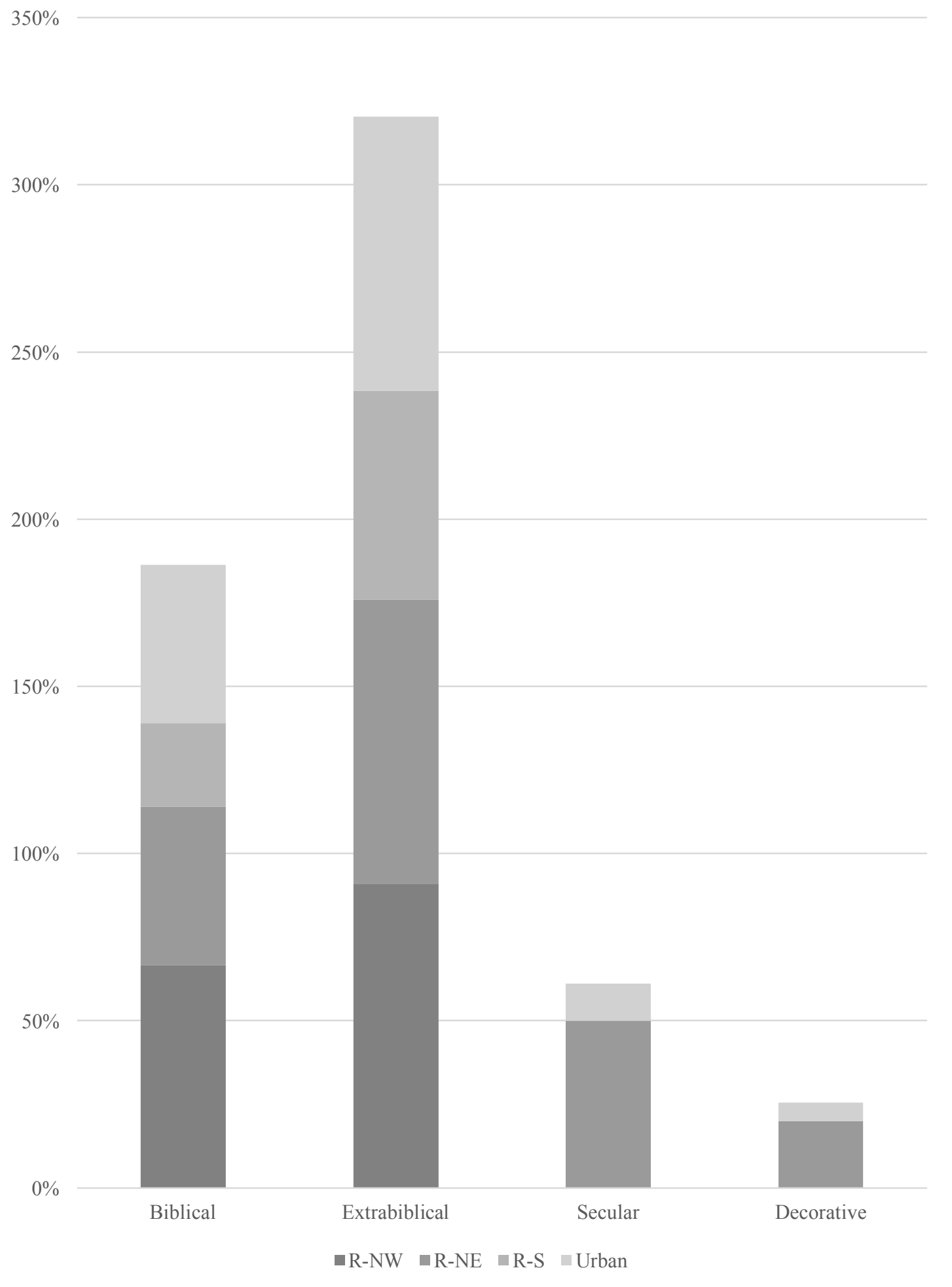

Figure 14: Screens: Rate of Iconoclasm 


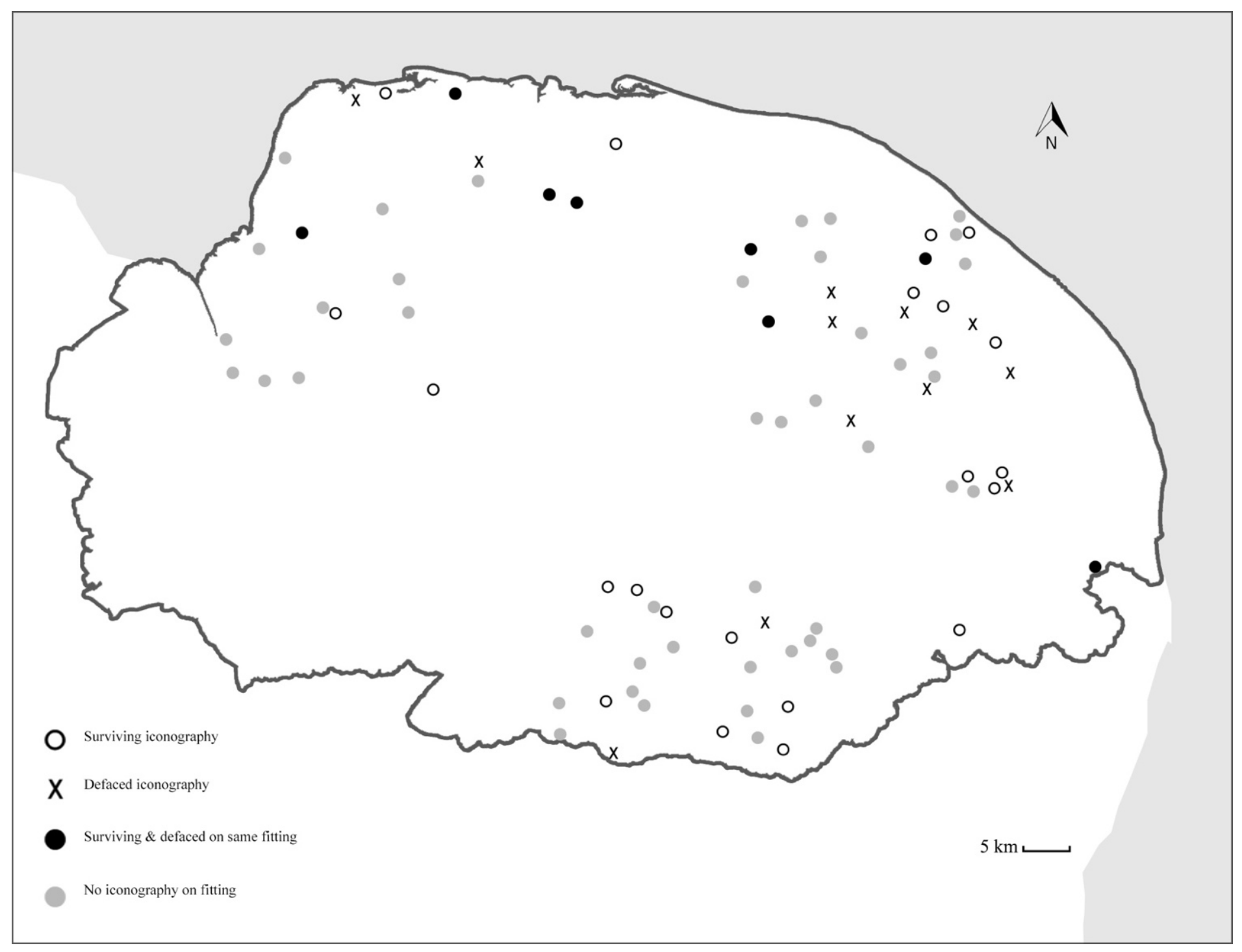

Figure 15: Screens: Map Distribution 


\section{R-NW Sample}

This section will examine two defaced medieval rood screens located in the parishes of Thornham and Dersingham. While Thornham was selected for its close ties to Norwich diocese and damaged Old Testament iconography found on its screen, Dersingham retains foreign extrabiblical iconography that was defaced in a very distinctive manner.

\section{Case Study: Thornham}

The village of Thornham, located on the northern coast of Norfolk, was dominated by the see of Norwich, as the bishop held both a manor and the rectory of All Saints church following the resolution of a conflict between Herbert de Losinga, founder of the Cathedral, and the House of Warrene (Blomefield, 1809, p. 391). In 1209, another manor held by Simon de Thornham was granted to William de Walsham, prior of the Cathedral Priory of the Holy Trinity of Norwich. These strong ties between this rural village and the religious authority of the provincial capital ensured that the subsequent reforms would be manifest with direct consequences.

The parish endured massive upheavals in the wake of the Henrician religious innovations, as the estates belonging to the Norwich episcopacy passed to the Crown in exchange for St. Benet's Abbey, which survived as the only monastic house spared dissolution when the abbacy was united with the bishopric (Blomefield, 1809, pp. 39193). Thornham Manor was granted to William Butts, one of the founders of the Royal College of Surgeons and obstetrical physician to two queen consorts, Anne Boleyn and Jane Seymour (Gunthrie, 1945, pp. 149-151), while the bishop retained the rectory and transformed the church into a vicarage, or residence of a vicar. This arrangement did not last long, as the manor soon reverted back to the Crown during the reign of Elizabeth before being purchased by Edward Coke, Chief Justice of the King's Bench under James I. In 1618, Coke offered the estate as part of a dowry to John Villiers, who would become the first Viscount Purbeck the following year, and the elder brother of the royal favorite, George Villiers, first duke of Buckingham (Blomefield, 1809, p. 393). As for the manor belonging to Norwich Priory, it was transferred to the new dean and chapter upon its dissolution and secular refounding. 
In the late fifteenth century, the church, dedicated to All Saints, underwent extensive renovations funded by the prominent Miller family, who were affluent merchants in the parish. John and Clarice Miller donated a magnificent rood screen (Plate 31-32), with the former requesting to be buried in the east end of the nave near the fitting (Farrow, 1943). The sixteen dado panels feature a unique compilation of biblical, from the Old and New Testaments, and extrabiblical figures; all featuring various degrees of facial damage and wear. The northern end of the dado features: St. Barbara, St Paul, Amos, Hosea, Zechariah, Isaiah, David, and Jeremiah with the southern end featuring: Zephaniah, Joel, Micah, Malachi, Daniel, Ezekiel, Lazarus, and St. Mary Magdalene. In sharp contrast to the traditional use of the twelve apostles, the inclusion of twelve Old Testament figures, including all four major prophets, seven of the twelve Minor Prophets and King David, is significant as each figure is the traditional author of a portion of the biblical text. The New Testament is represented by a continuation of the biblical author motif with St. Paul; and St. Mary Magdalene and Lazarus, two figures with ties to the divine miracle of resurrection as both a witness and recipient, respectively. The lone image depicting a figure unrelated to scripture is St. Barbara, holding a church designed in the Byzantine style. Each of the sixteen paintings features the figures pointing to a scroll with text from the Old Testament Latin Vulgate, a common motif when presenting a figure with scriptural text (Nichols, 2002, p. 308). While these snippets of text do not feature a reference, as the artist was often providing the citation from memory (Cartier, 1865, p. 165), the name of the prophet can often be seen along the bottom perimeter of the panel.

The use of Old Testament iconography is an extension of a medieval motif, which associated the prophets with the Twelve Apostles (Table 10). This is not the only case that such a correlation was used, as the four major prophets: Isaiah, Jeremiah, Ezekiel, and Daniel, were often juxtaposed to the four evangelists (Sill, 1996). It was common for text from the Apostles' Creed to be divided amongst the apostles and presented as being professed alternating with prophetic quotes from the Jewish scripture. In addition to the images on display at Thornham, additional prophets could be used in this formula, including Obadiah, Haggai, and Solomon. This motif forged a strong connection between Christianity and its religious forbears, as it reinforced the ideal that 
the prophets not only anticipated the coming of Christ but also helped lay the groundwork for the establishment of the Church (Cartier, 1865, pp. 139-142). The correlation between these images with both scripture, and their New Testament counterparts, suggests a nuanced understanding and appreciation for the biblical texts.

The three panels depicting New Testament figures is a unique assemblage, presenting three of the most integral saints in Christian scripture outside of the Virgin and the Twelve Apostles; the latter were already indirectly represented in the twelve Old Testament panels. While the images of St. Paul, St. Lazarus and St. Mary Magdalene all have portions of their faces scratched out, the carving of St. Barbara, the thirdcentury martyr, holding her three-windowed tower suffered the most with nearly the entire head scraped off. It should be noted that the artist defined a clear distinction between those figures that were post-Resurrection Christians, as only Paul, Mary and Barbara are adorned with a nimbus. 


\begin{tabular}{|c|c|c|c|}
\hline Panel & Prophet/Apostle & Scripture/Creed & Reference \\
\hline \multirow[t]{2}{*}{$\mathrm{N}-8$} & Jeremiah & $\begin{array}{l}\text { Patrem vocabis me et post me ingredi non } \\
\text { cessabis. }\end{array}$ & Jeremiah 3.19 \\
\hline & St. Peter & $\begin{array}{l}\text { I believe in God the Father almighty, creator of } \\
\text { heaven and earth. }\end{array}$ & Article 1 \\
\hline \multirow[t]{2}{*}{$\mathrm{N}-7$} & David & $\begin{array}{l}\text { Dominus dixit ad me filius meus es tu ego hodie } \\
\text { genui te. }\end{array}$ & Psalms 2.7 \\
\hline & St. John & I believe in Jesus Christ, his only Son, our Lord. & Article 2 \\
\hline \multirow[t]{2}{*}{$N-6$} & Isaiah & Ecce virgo concipiet et pariet filium. & Isaiah 7.14 \\
\hline & St. James & $\begin{array}{l}\text { He was conceived by the power of the Holy } \\
\text { Spirit and born of the Virgin Mary. }\end{array}$ & Article 3 \\
\hline \multirow[t]{2}{*}{$N-5$} & Zechariah & Aspicient ad me quem confixerunt. & $\begin{array}{l}\text { Zechariah } \\
12.10\end{array}$ \\
\hline & St. Andrew & $\begin{array}{l}\text { Under Pontius Pilate, He was crucified, died, } \\
\text { and was buried. }\end{array}$ & Article 4 \\
\hline \multirow[t]{3}{*}{$\mathrm{N}-4$} & Hosea & $\begin{array}{l}\text { O mors, ero mors tua; ero morius tuus, } O \\
\text { inferne. }\end{array}$ & Hosea 13.14 \\
\hline & St. Philip & He descended to the dead. & Article 5 \\
\hline & St. Thomas & On the third day he rose again. & Article 5 \\
\hline \multirow[t]{2}{*}{$\mathrm{N}-3$} & Amos & Qui aedificat in caelo ascensionem suam. & Amos 9.6 \\
\hline & St. Bartholomew & $\begin{array}{l}\text { He ascended into heaven and is seated at the } \\
\text { right hand of the Father. }\end{array}$ & Article 6 \\
\hline \multirow[t]{2}{*}{$S-4$} & Malachi & Et accedam ad vos in iudicio et ero testis velox. & Malachi 3.5 \\
\hline & St. Matthew & $\begin{array}{l}\text { He will come again to judge the living and the } \\
\text { dead. }\end{array}$ & Article 7 \\
\hline \multirow[t]{2}{*}{ S - 2} & Joel & Effundam spiritum meum super omnem carnem. & Joel 2.28 \\
\hline & $\begin{array}{l}\text { St. James } \\
\text { (Alpheus) }\end{array}$ & I believe in the Holy Spirit. & Article 8 \\
\hline \multirow[t]{2}{*}{ S - 1} & $\begin{array}{l}\text { Zephaniah or } \\
\text { Solomon }\end{array}$ & Communicabit mcum de honis. & Wisdom 8.9 \\
\hline & St. Simon & $\begin{array}{l}\text { The holy catholic Church, the communion of } \\
\text { saints, }\end{array}$ & Article 9 \\
\hline \multirow[t]{2}{*}{$S-3$} & Micah & Deponet iniquitates nostras. & Micah 7.9 \\
\hline & St. Jude & The forgiveness of sins, & Article 10 \\
\hline$S-5$ & Daniel & Educam vos de sepulchris vestris populus meus & Ezekiel 37.12 \\
\hline \multirow[t]{2}{*}{$S-6$} & Ezekiel & $\begin{array}{l}\text { Evigilabunt: alii in vitam aeternam, et alii in } \\
\text { opprobrium. }\end{array}$ & Daniel 12.2 \\
\hline & St. Matthias & $\begin{array}{l}\text { The resurrection of the body and the life } \\
\text { everlasting. }\end{array}$ & Article 11,12 \\
\hline
\end{tabular}

Table 16: Screens: Thornham 

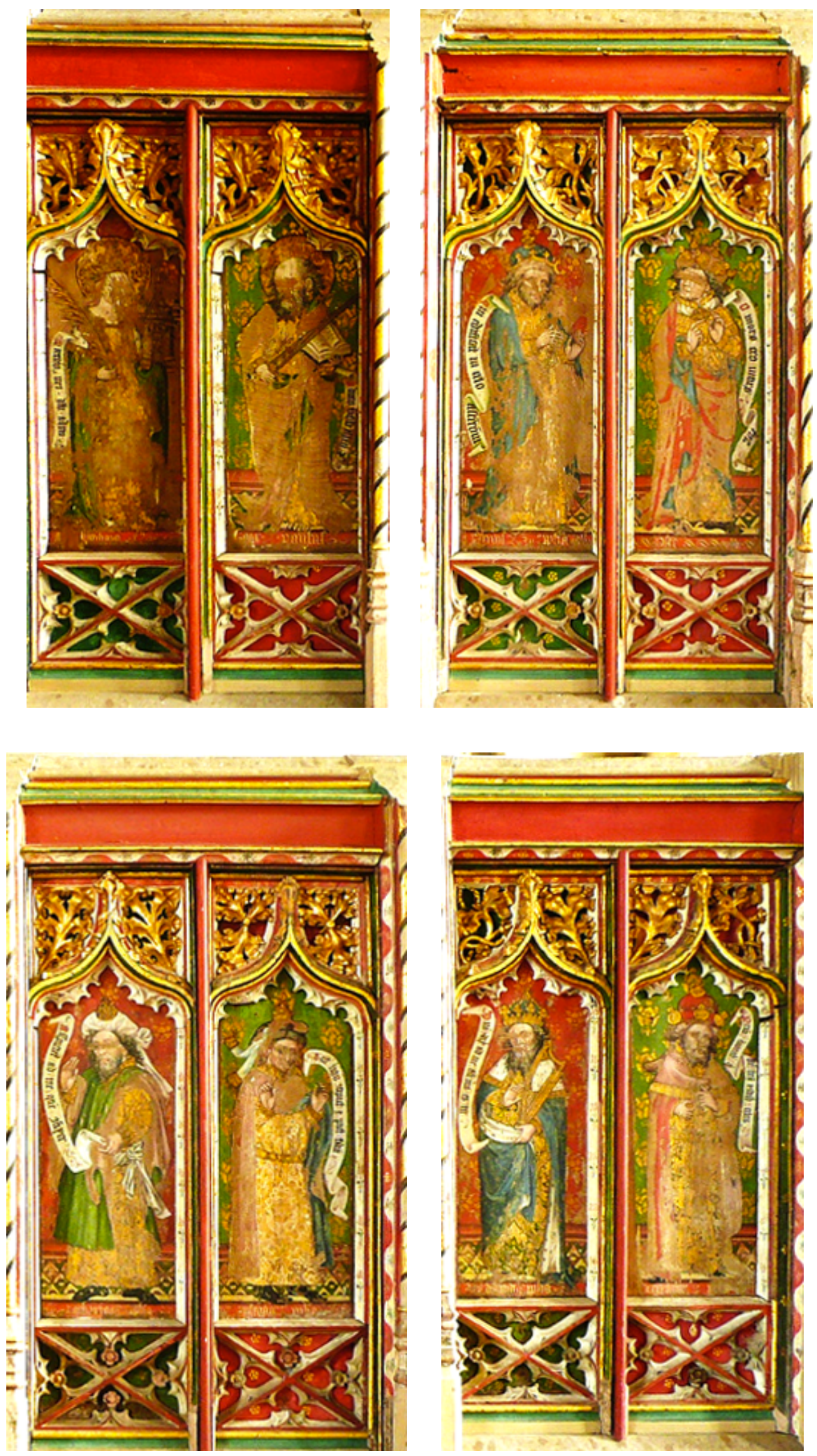

Plate 32: Screen: Thornham. South Side 

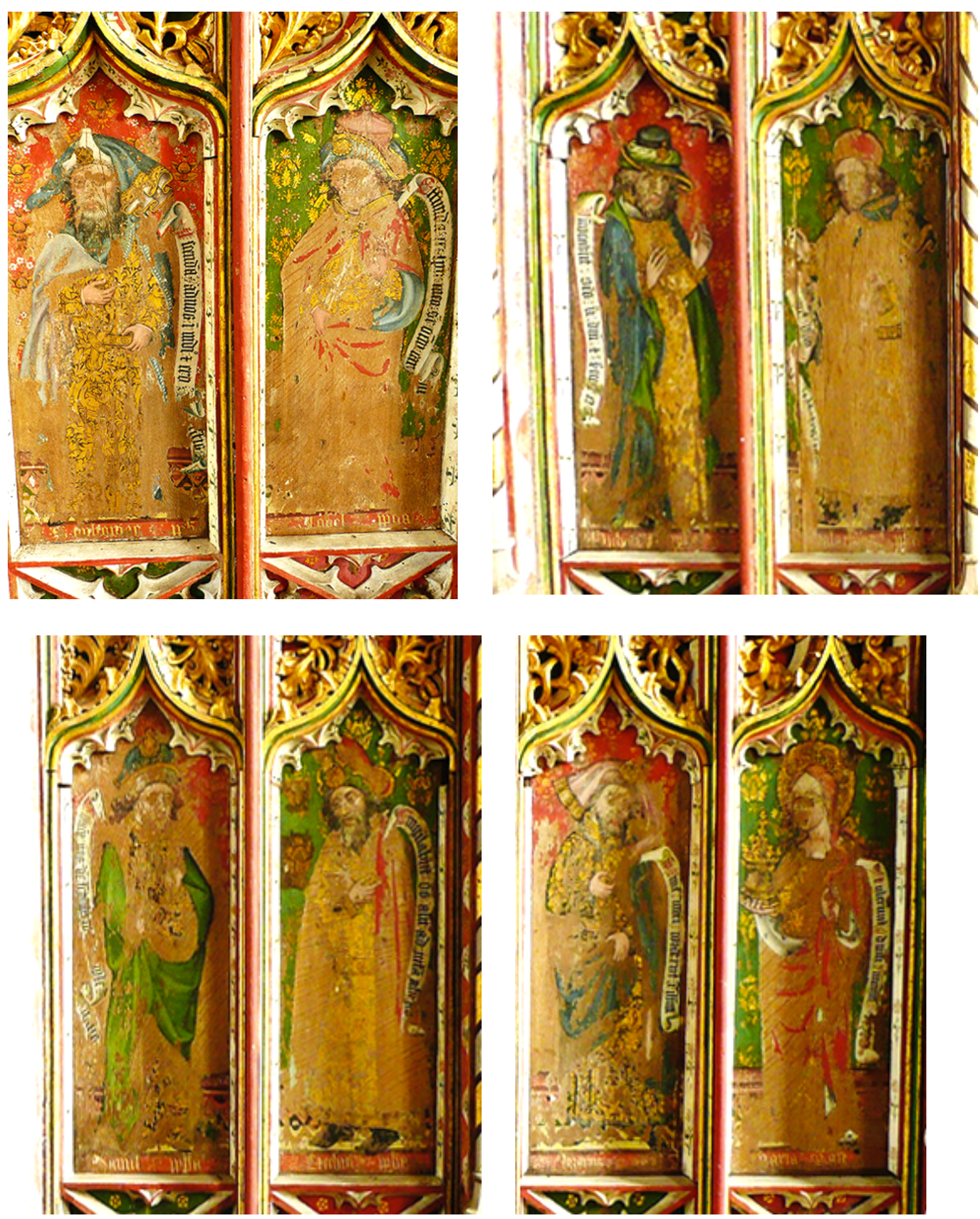

Plate 33: Screen: Thornham. South Side 


\section{Case Study: Dersingham}

The village of Dersingham, located just north of both King's Lynn and Sandringham, the house of Queen Elizabeth II, is home to St. Nicholas Church. The building was rebuilt in the Gothic Decorated style in the fourteenth century before receiving new Perpendicular Gothic windows at some point in the fifteenth century. The northern dado of a fifteenth-century rood screen has survived (Plate 33), with the six painted oak panels exhibiting signs of iconoclasm. These images were uncovered in the nineteenth century, as the already damaged panels were covered in paint as a final suppression of the offensive iconography. The defaced images are all derived from tradition and history outside of the Bible, ranging from early martyrs to English clergy. From north to south, the saints on display are: St. Agatha, St. Denis, St. Agnes, St. Hubert, St. Martin, and an unidentified archbishop of Canterbury. The omission of any Biblical saints from this collection may suggest a similar trend could have existed on the missing six southern panels.
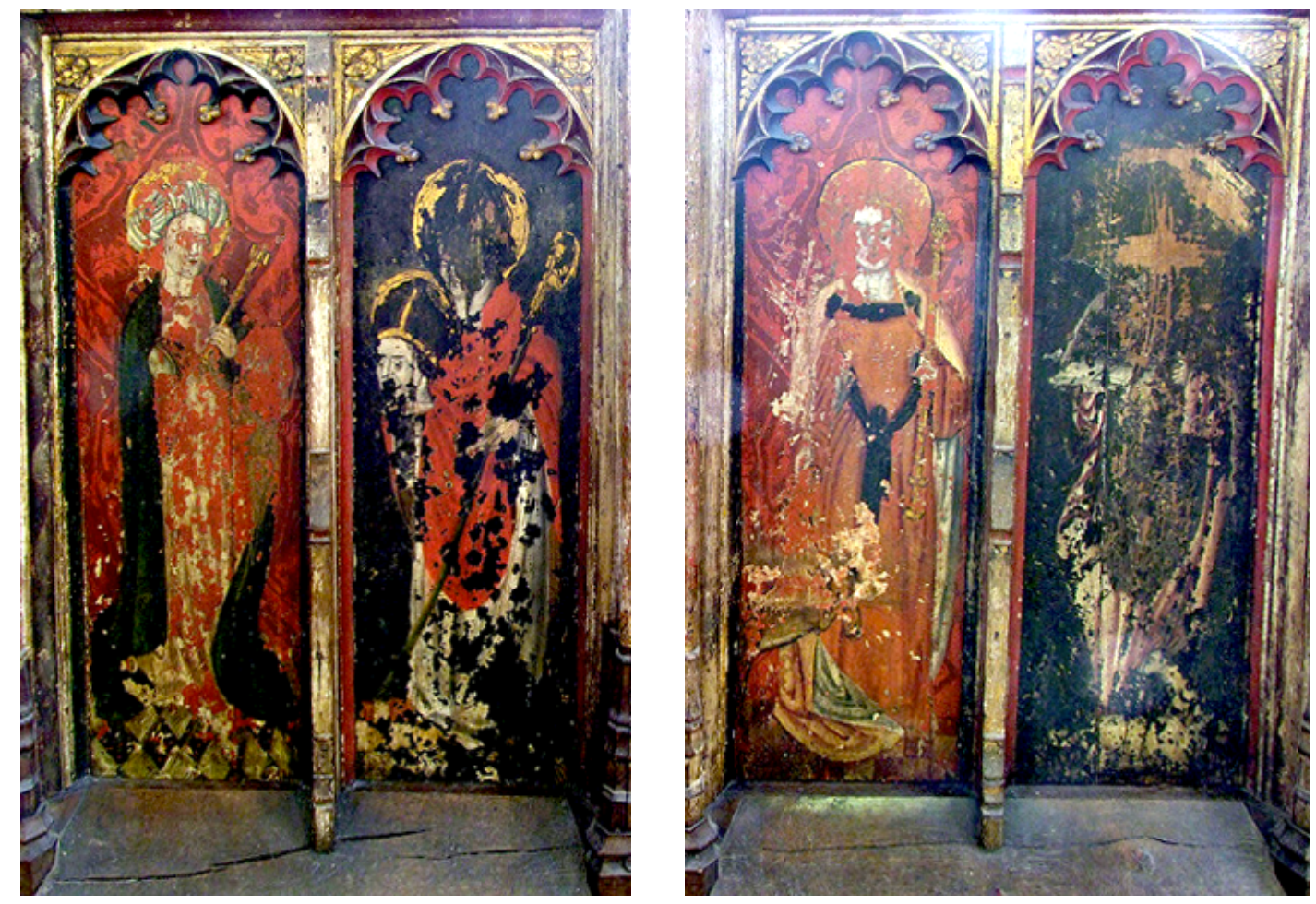

Plate 34: Screen: Dersingham

From left to right: St. Agatha, St. Denis, St. Agnes, St. Hubert 
While each panel shows signs of defacement on the effigies' face and eyes, the images of St. Hubert and St. Denis shows the most severe signs of damage, with the upper portion of the latter barely visible beneath gouges in the shape of a cross. The extremity of the damage to these figures may be associated with xenophobia rather than strict religious effrontery. St. Hubert, or Hubertus, was an eighth century bishop of Liège, a Walloon-speaking area of southern Belgium, who emerged as a patron saint of hunters. If nationalism played a part in the severity of damage this image suffered, then it should not come as a surprise that an effigy of Denis, the third century bishop, and later patron saint, of Paris, was deemed inappropriate for display within an English house of worship.

\section{R-NE Sample}

Two damaged medieval rood screens, located in the parishes of North Burlingham and Cawston, were examined for this sample. The case at North Burlington features extrabiblical images painted on a screen dated two years after the Royal Supremacy; however, the planning for this ornamentation took place just before the start of the Reformation. The Cawston screen, one of the most magnificent in Norfolk, demonstrates the different levels of iconoclasm leveled against biblical and extrabiblical images together in the same assemblage.

\section{Case Study: North Burlingham}

The small village of North Burlingham (today united with Lingwood, South Burlingham, and Burlingham Green), and its church dedicated to St. Andrew, provides an excellent case of passive resistance to the Reformation through the late implementation of offensive iconography and procedural noncompliance by the rector. The lords of the manor, the De Caston family, held the advowson of the church until it passed to Sir Robert Carbonel of Bodingham, Suffolk through his marriage to Elizabeth de Caston, in the fourteenth century. It is possible that this transference of patronage to an absentee lord enabled more local influence to dictate the direction the parish would take in the following century.

The parish church retains an oak rood screen dated to 1535 , with a twelve-panel dado featuring ten heavily disfigured paintings (Plate 34-35). The northern side of the screen 
presents: St. John the Baptist, St. Cecilia, St. Walstan, St. Catherine, St. Edmund and St. Etheldreda; while the southern side features: St Thomas of Canterbury, King Edward the Confessor, St. Benedict and St. Withburga. Each image was originally adorned with the name of the donors associated with each representation; these are no longer visible. In spite of this, local research undertaken within the parish has been able to identify six names with three of the panels, which demonstrates that the creation of the screen was a collective effort which better reflects the theological imperative of the community at the dawn of Reformation, as opposed to the narrow vision of a single family responsible for financing the entire project (Hill, 1939, pp. 14-30). It should be noted that the choice of these particular images for this screen was uncommon this late in the century, as half of the images are local, Norfolk or English, saints and only one being a Biblical saint.

By 1538, discord within the church continued as the rector ceased providing his signature to the church registers, leaving only the churchwardens to certify information until 1602 when the new priest, John Robison, retroactively signed for the previous sixty-four years (Hill, 1939, pp. 14-30). The collision between progressive clergy and the conservative parish continued as Matthew Parker, the future archbishop of Canterbury (1559 - 1575) and leading proponent of the new Anglican doctrine, became rector of St. Andrew in 1544 (Blomefield, 1807, pp. 222-226). It is difficult to gauge Parker's influence in the parish, as the same year he took it up, he was elected master of Corpus Christi College on the king's recommendation. By 1547, Parker resigned as rector and married Margaret, daughter of Robert Harlestone, a Norfolk squire. This move, which coincided with the massive reforms that went along with the ascension of Edward VI, would have been very controversial in a conservative rural parish like North Burlingham (Bjorklund, 2003, p. 350).

The figures adorning the screen all feature heavy mutilation across the faces, with the damage done to St. Thomas of Canterbury extending down across the entire body, with traces of his books, cross, and staff still visible. Thomas Becket's clash with King Henry II was the most notorious cases in English history over the royal prerogative in church affairs until the Reformation. In spite of being royal chancellor to Henry II before his consecration as archbishop of Canterbury in 1162, Becket emerged as an 
exponent for ecclesiastical rights through both promoting benefit of the clergy, which would subject clergyman to church rather than secular justice, and the recovery of lost lands at the discretion of the archdiocese. While the bishops supported their senior churchman, Becket eventually submitted to the Constitutions of Clarendon in 1164, which restored the royal prerogative to where it had been under Henry I (Huscroft, 2005, pp. 192-95). Later that year, Becket was arrested for attempting to travel to France without permission, which led to him being charged with violating the provisions of Clarendon, in addition to having his financial affairs investigated from his time as chancellor. Rather than answering the charges, Becket fled to France, where he was granted the status of papal legate to England in 1166; a position that empowered him to excommunicate his enemies from abroad. Following the coronation of Henry's son as junior monarch by the archbishop of York in 1170, Becket was further empowered by the pope to lay an interdict on England for violating ecclesiastical protocol, which reserved the right to crown English kings for the archbishop of Canterbury. Henry prevented this fate by entering into negotiations with Becket, culminating in his return to England; however, not before excommunicating the three senior clergymen involved in the offensive coronation, including: Roger, archbishop of York, Josceline, bishop of Salisbury, and Gilbert Foliot, the bishop of London who had already been absolved from a previous Becket excommunication (Warren, 1973, pp. 506-509). Despite offering to absolve the two bishops, Becket claimed that only the pope could reverse the ruling on Roger, who convinced the bishops to travel to Normandy and appeal to Henry himself. Upon learning of events that had transpired, Henry proclaimed his desire to be "rid me of the turbulent priest," prompting four knights to journey to Canterbury where they brutally murdered Becket.

In an age where royal authority had overtaken ecclesiastic rights and privileges, it is apropos that a defiant parish would choose to incorporate this image in a position of prominence on the panoply, as images closest to the partition opening on the north side. Yet, the obvious passion and zeal in its destruction when compared to the other nine panels demonstrates the offense this image offered to reformers. Based on the late date of construction of this screen, and the lack of rector for part of Edward's reign, it can be inferred that this defacement may have occurred later in the Reformation process. By the sixteenth century, Thomas emerged as a polarizing figure; embraced by those who 
supported the sovereignty of the Church and rebuffed by those who agreed with the Royal Supremacy. This dichotomy is visually captured through both the late creation of such a representation and the subsequent enormity of its destruction.

The image of St. John the Baptist, positioned far from the screen opening on the northern half of the dado, is the only Biblical image featured. The defaced iconography chosen for the representation evokes the proclamation of Christ as the sacrificial savior, as evidenced by the figure holding a book topped with a small lamb and the Latin inscription Ecce Agnus (John 1.29).

The use of additional images of early saints provides a visual hagiography, with three panels presenting figures of importance to the Roman Catholic teachings. The painting of St. Cecilia is not shown in conventional form, as the patron saint of musicians; instead, her life and death are highlighted by her crown of white flowers, a symbol of her divine virginity even in marriage, her emblem of martyrdom and three stigmatic wounds to her neck. The role that the Lord plays in Cecilia's marriage to Valerian, from her maintained virginity to his conversion and their final sacrifice, may have served as a sharp contrast to the continued marital conflict of Henry VIII.

The use of St. Catherine and St. Benedict, saints associated with secular and religious learning, may have been chosen as a reminder that the domain of education was reserved for those qualified. The image of Benedict features him wielding his pastoral staff and a closed book with two naked, and wounded, demons at his feet. His role as a restorer of monastic discipline is highlighted through both his abbot's habit and book inscribed with the opening line of his precepts, instructing the reader to hear the words of the master (Avscvlta Fili, verba Magistri). This emphasis on Benedict's contributions to Christian monasticism would have been a striking contrast to the ongoing visitations and suppressions facing the monasteries across England. Within three years of the completion of this rood screen, the Benedictine monks at Norwich Cathedral became the first cathedral priory to be dissolved following their surrender to Henry VIII; it was transformed into a secular establishment with a dean and chapter comprised of the submissive prior and monks (Gilchrist, 2005, p. 200). 

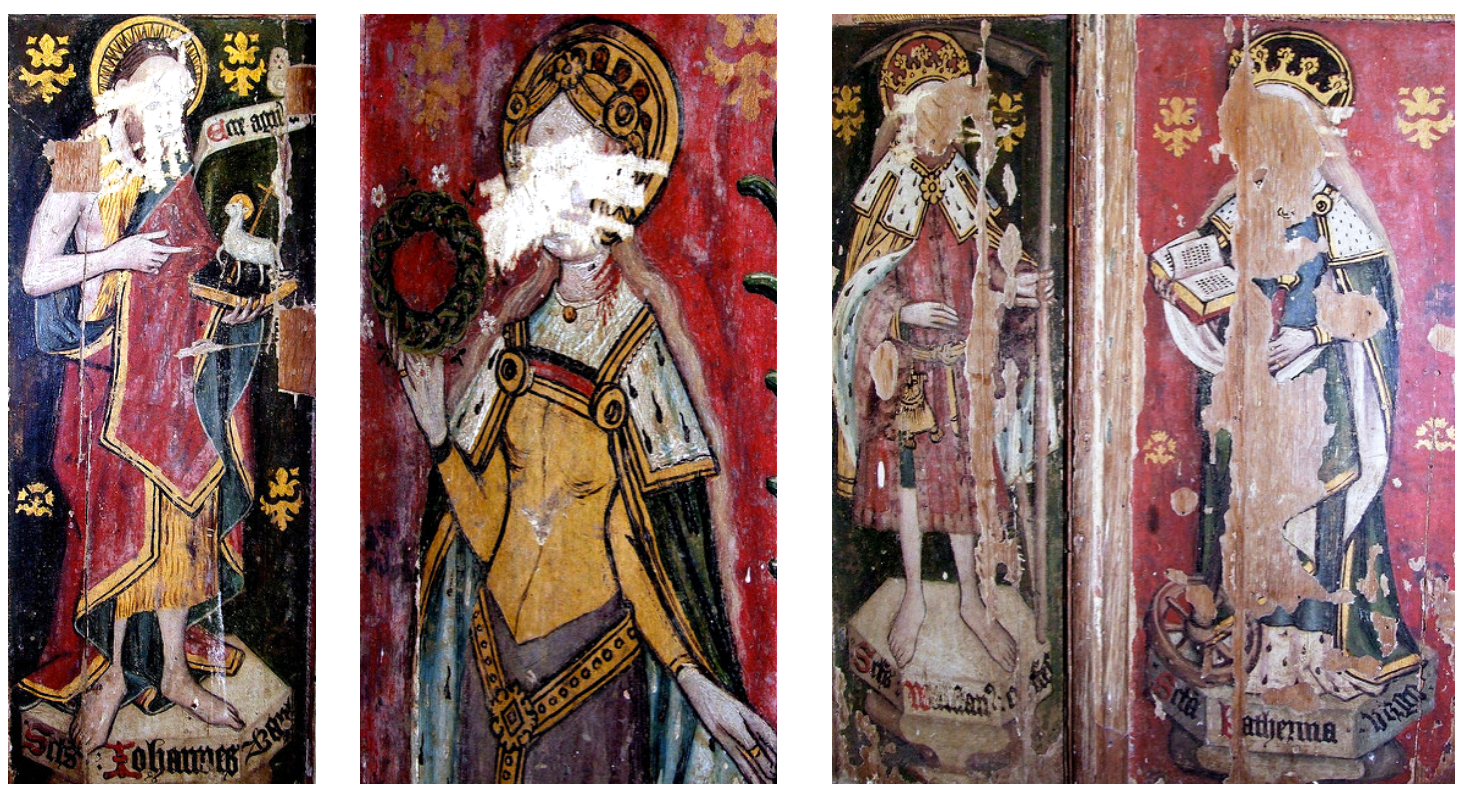

Plate 35: Screen: North Burlingham. North Side

From left to right: St. John the Baptist, St. Cecilia, St. Walstan,

St. Catherine. St. Edmund (Photo bv Simon Knott)

Finally, the pronounced use of saints tied to local tradition suggests an affinity within the parish for their own history. The importance of agriculture to a rural village like North Burlingham is acknowledged with a representation of St. Walstan, a charitable Norfolk farmer who prayed and labored in fields between Bawburgh and Taverham before perishing in 1016. After emerging as the patron saint of farmers, his veneration in art was usually confined to rural locales in Norfolk and Suffolk (James, 1917). This Anglo-Saxon theme continues several panels away with St. Edmund, king of the East Angles and namesake for another parish church located in South Burlingham. His story would have been especially poignant at the time this screen was erected, as King Edmund strove to restore both churches and monasteries in the face of invading Danes. His efforts culminated in defeat in battle and subsequently discovery hiding in a church before being captured, beaten and executed. His remains were brought to Bury in 903, where a powerful and influential Benedictine monastery was founded. Like the panel featuring St. Benedict, this image suggests a local mood contrary to the policies being implemented by Henry VIII. While the image of St. Edmund, highlighting his martyrdom by arrows, was a typical piece of iconography found across Norfolk before the Reformation, this image was unveiled only four years before the suppression, and subsequent destruction, of Bury St Edmunds Abbey (Freeman, 1895, p. 110). 
This motif of monastic veneration continues with effigies of both St. Etheldreda and St. Withburga; two women tied to the Anglo-Saxon religious tradition of East Anglia. These women represent two of the four saintly daughters of Anna, the seventh-century king of the East Angles. The story of Etheldreda, or Audrey as she is sometimes called, represents another case where both royal and divine prerogatives collided. Following her marriage to Ecgfrith of Northumbria, the future king of Deira, she became a nun and arranged for her marriage to remain unconsummated. Despite initially agreeing, Ecgfrith soon changed his mind and attempted to win the support of Wilfrid, the bishop of York, to help him convince the queen to abandon her vow of celibacy. After this approach had failed, the king moved to use both coercion and force; a tactic which forced Etheldreda to flee the cloister and return to Ely, where she would go on to establish a double monastery. The screen painting features the duality of her life, as a princess of East Anglia, with a crown, and as the abbess of Ely, wearing her habit. Her story demonstrates what happens when the secular machinations of a monarch come into opposition to the divine sacrality of monastic life; a theme which must have provided hope for a conservative parish witnessing the deconstruction of a world that figures like Etheldreda helped build. 

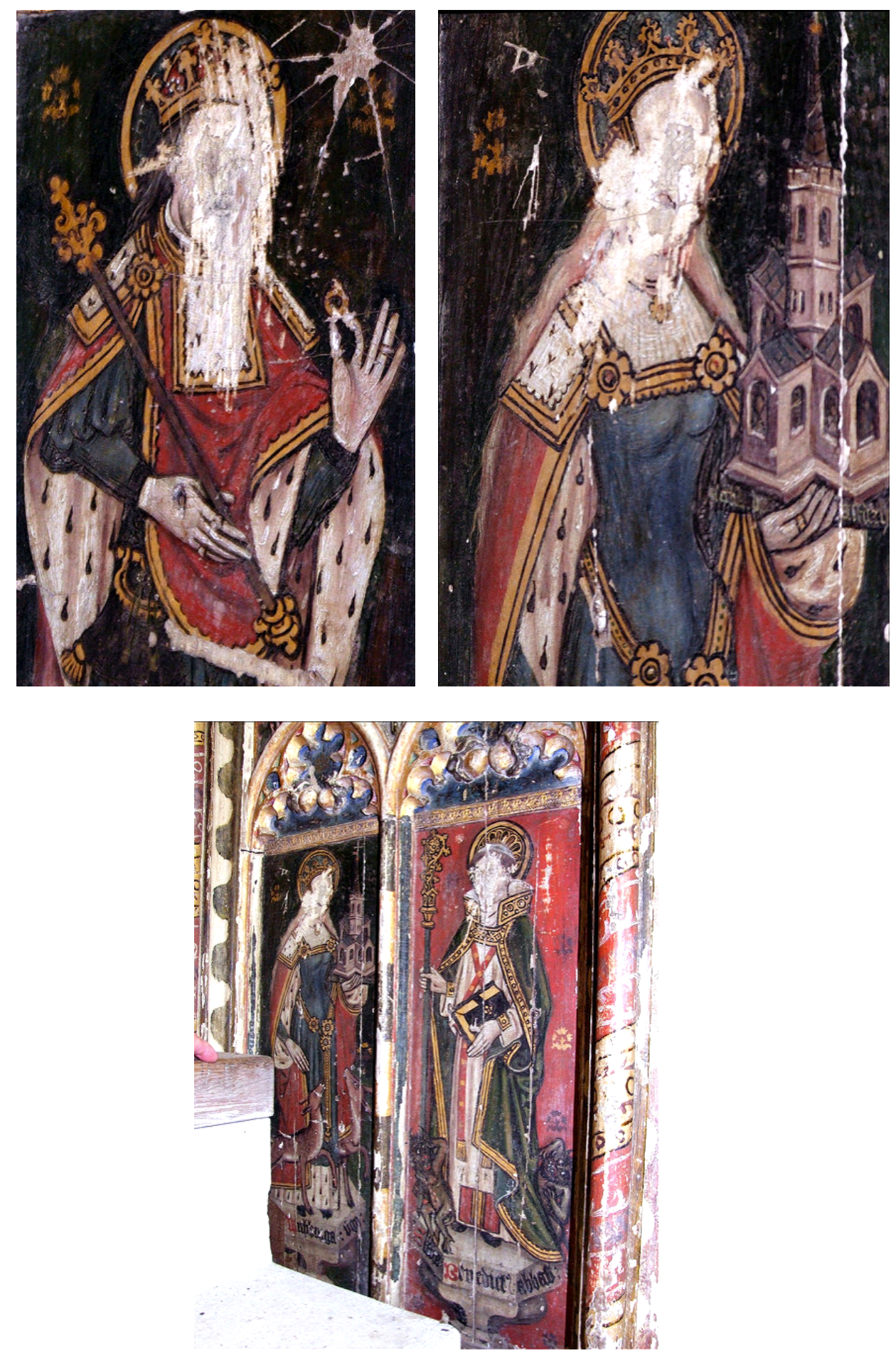

Plate 36: Screen: North Burlingham. South Side

Left to right: St Thomas of Canterbury, King Edward the Confessor,

St. Benedict and St. Withburga (Photo by Simon Knott) 


\section{Case Study: Cawston}

Cawston, a small village north of Norwich, demonstrates the prestige that an influential landlord could provide a diminutive parish. This manor continuously passed between the Crown and the earls of Suffolk; until 1385, when Richard II provided the lands to his Lord Chancellor, Michael de la Pole, who was offered the earldom. His support for Richard resulted in his position being compromised by the Lords Appellant, a group of nobles who challenged the king's rule by seeking to undermine his ability to install ministers of his own choosing. After fleeing to France, de la Pole was stripped of his holdings and sentenced to death, a conviction that would never be carried out. His son, also Michael, chose to yield to Henry Bolingbroke's claim on the English throne, resulting in the restoration of some of his father's lands and title. It may have been an attempt to rehabilitate the family name that led to Michael, and his wife Katherine, investing in the massive rebuilding of the parish church, dedicated to St. Agnes. The desire to distance themselves from their troubled past also resulted in this Michael, and his son, Michael, joining Henry V on England's military adventures in France; which resulted in both perishing within a few months of one another in 1415. Michael's remaining son, William, became the fourth earl of Suffolk before being created marquess in 1444, and later, duke of Suffolk in 1448. His continued successes could be attributed to his prominence in the court of Henry VI, evidenced by his selection to negotiate the marriage with Margaret of Anjou in 1444. These negotiations, which included a provision for the return of Maine and Anjou to France, resulted in the duke taking the blame for the subsequent erosion of English holdings on the continent. With his support in London diminished, his enemies in Norfolk, such as the Paston family, seized upon the opportunity to turn local opinion against him and lay accountability on him for the East Anglian lawlessness (Curran, 2011, pp. 261-262). In spite of his strong ties to Henry, whose own position was becoming tenuous, William was arrested and exiled; however, he was captured, tried and executed on his journey to France (Davis, 1958, pp. 26-29). Cawston passed to his son, John, who was married to Elizabeth of York, sister of Edward IV and Richard III. In the wake of the Yorkist collapse at Bosworth, John swore allegiance to Henry VII and was allowed to retain his position. His heir, Edmund, who succeeded his father's position when his older brother John predeceased their father, emerged as a potential claimant to the throne; resulting in Henry demoting his title back to earl and even seizing some holdings, including 
Cawston (Blomefield, 1807, pp. 26-64). In 1504, Henry VIII granted the manor to Gerald FitzGerald, eighth earl of Kildare, who held it until his death in 1513. In the following year, Margaret de la Pole, wife of the recently executed Edmund, petitioned to regain her husband's forfeited lands for the remainder of her life. While this request was granted, her passing in 1516 resulted in Cawston again returning the Crown. In 1539, Henry exchanged these lands to James and Elizabeth Boleyn; uncle and aunt to his second wife, Anne. In 1550, an order was filed with the Exchequer for the manor to go to Anne's daughter, Elizabeth upon their passing. These bestowals resulted in Cawston once again returning the Crown, as Elizabeth had ascended to the throne by 1562. After the land was leased for four decades, King James I sold the manor and advowson to Henry Hobard, his attorney general in 1610 (Blomefield, 1807, pp. 260264).

The purpose of this chronology of authority is to provide a context for this rural parish, which was never granted an opportunity to be out of step with royal politics. While the earls and later dukes of Suffolk provided a degree of stability and separation, their prominence in national affairs must have helped shape the local parish identity; while the direct royal control during most of the sixteenth century would have no doubt played a role in the way the Reformation was received. Furthermore, the forfeiture of these lands by the original benefactors, and installation of new absentee lords, eliminated any strong local ties, which may have potentially shielded the church from any gratuitous vandalism.

The rood screen found at St. Agnes in Cawston is one of the most magnificent and largest medieval furnishings in all of Norfolk, featuring eight dual-panel dado bays with another two dual-panel bays located on the center gate (Plate 36-38). While the surviving upper portion is simple open tracery, the sixteen paintings are of remarkable quality and adorned with molding, and vibrant floral patterns are characteristics of the East Anglian style.

Three distinct artistic styles can be observed, suggesting that the dado was decorated in stages. The northern portion of the screen features St Agnes and her lamb, St Helena and her cross, St. Thomas, St John the Evangelist, St James, St. Andrew, St. Paul, and 
St. Peter. These images, all painted by the same artist, originally featured the inscription "Prey for the Sowlis of William Athereth, and Alice his Wyff, the wcche dede these iiii Panys Peynte be the Erecutoris lyff' (Blomefield, 1807, pp. 267-68). The next six images created by another painter, including four on the central screen gates and two on the south dado, feature the Four Latin Doctors, St. James the Less and St. Bartholomew. The artistic prowess of these panels is not of significance when compared to the north and south collection flanking, as the detail and use of color is nowhere near as elaborate (Strange, 1913, pp. 82-84). While the screen is not dated, it can be reasoned that it was completed between 1490 and 1510 (Duffy, 2004, p. 336). The earliest reference to this fitting is from the will of John Barker who left an endowment for new seating and for a rood loft in 1460, which suggests that the church was still years away from requiring a partition.

The final six images, feature: St Philip, St Jude, St Simon, St Matthew, depicted with his glasses which identified him as both tax collector and author, St Matthias, and Sir John Schorne. This series displays a level of realism far greater than the preceding fourteen images, suggesting that facial details may have derived from living models. It has been suggested that the same artist may have been involved in the creation of the screen found at Worstead, as Jude and Simon have identical draperies; however, this particular screen appears to have also drawn inspiration from depictions of Peter, Paul and Andrew produced by the Dutch painter and engraver Lucas van Leyden in the year preceding the completion of this screen in 1512 (Moore, 1996, p. 356). The six images found on the southern dado at Cawston must be later additions than the rest of the screen, produced on vellum and glued over the preexisting artwork. As the style of these images can be traced to the early sixteenth century, when this and similar screens were constructed, it can be deduced that these reproductions were stencils of the original works. The most appropriate chronology would be for the original images to have been damaged during the Edwardian reign, only to be restored during that of Mary (Strange, 1913, p. 82). The significant enhancements to the faces could easily be explained: while the bodies could be copied the erasure of the original heads required original work to complete the restorations. 
The surviving traces of iconoclasm found on this screen, with slight damage found to the eyes of each figure, can mostly be attributed to nineteenth-century adolescent vandalism as opposed to destruction instigated on religious grounds (Strange, 1913). While St. Helena exhibits minor signs of additional damage on the face, the representation of Sir John Schorne suffered the most severe mutilation across both the face and over whatever the figure is holding in its left hand. Schorne, an early fourteenth-century rector from North Marston in Buckinghamshire, was a local saint who never received an official canonization, despite a plethora of miraculous healings. From other visual depictions, it can be assumed that the figure had been holding a boot containing a small devil. The trend of targeted destruction of select images is consistent with this one panel being chosen for defacement, which may have been the second time this image was damaged as it had previously been replaced a vellum reproduction.

The paintings of the apostles remain relatively unscathed, while the remainder of the extrabiblical figures possesses an interesting mix of damage. St. Agnes, the church's namesake, endured in good condition; however, the Latin Doctors, or Teachers of the Faith in the Anglican tradition, include a heavily damaged image of St. Gregory. No image on this screen could compete with the sheer popery found on this panel, complete with papal tiara and ferula, or staff. Both the face and top of the staff have been erased from the image. The image of St. Augustine also bears signs of minimal damage, closer in scope to what is seen on the image of Helena rather than either Gregory or Schorne.

This outstanding collection of paintings indicates the precision of iconoclasm, which engaged closely with the subject matter of the images that were being defaced. The four images to suffer intentional mutilation, two minor and two severe, all represent saints who lived outside the confines of Scripture; or in the case of Schorne, official canonization. Biblical saints, or one who had a special connection with the consecration of the church itself like Agnes, were excused and must not have been deemed as offensive. In spite of the mixed survival rate of the Latin Doctor motif in this study, reformers could not abide the ultra-Catholic representation of Gregory. This complex relationship between the Reformation and these four saints can also be seen in 
the parish of Lessingham, although outside the confines of this study, connected to Cawston by also utilizing vellum images upon rood screen panels. The screen found in this church, dedicated to All Saints, replaced five damaged Apostles panels with parchment images of the Doctors along with St. Giles (Strange, 1913, pp. 81-82); yet, these post-Reformation updates did not last long and suffered subsequent destruction at some later point. Unlike the martyrs of the Christian faith themselves, the visual commemorations to them could suffer multiple deaths.
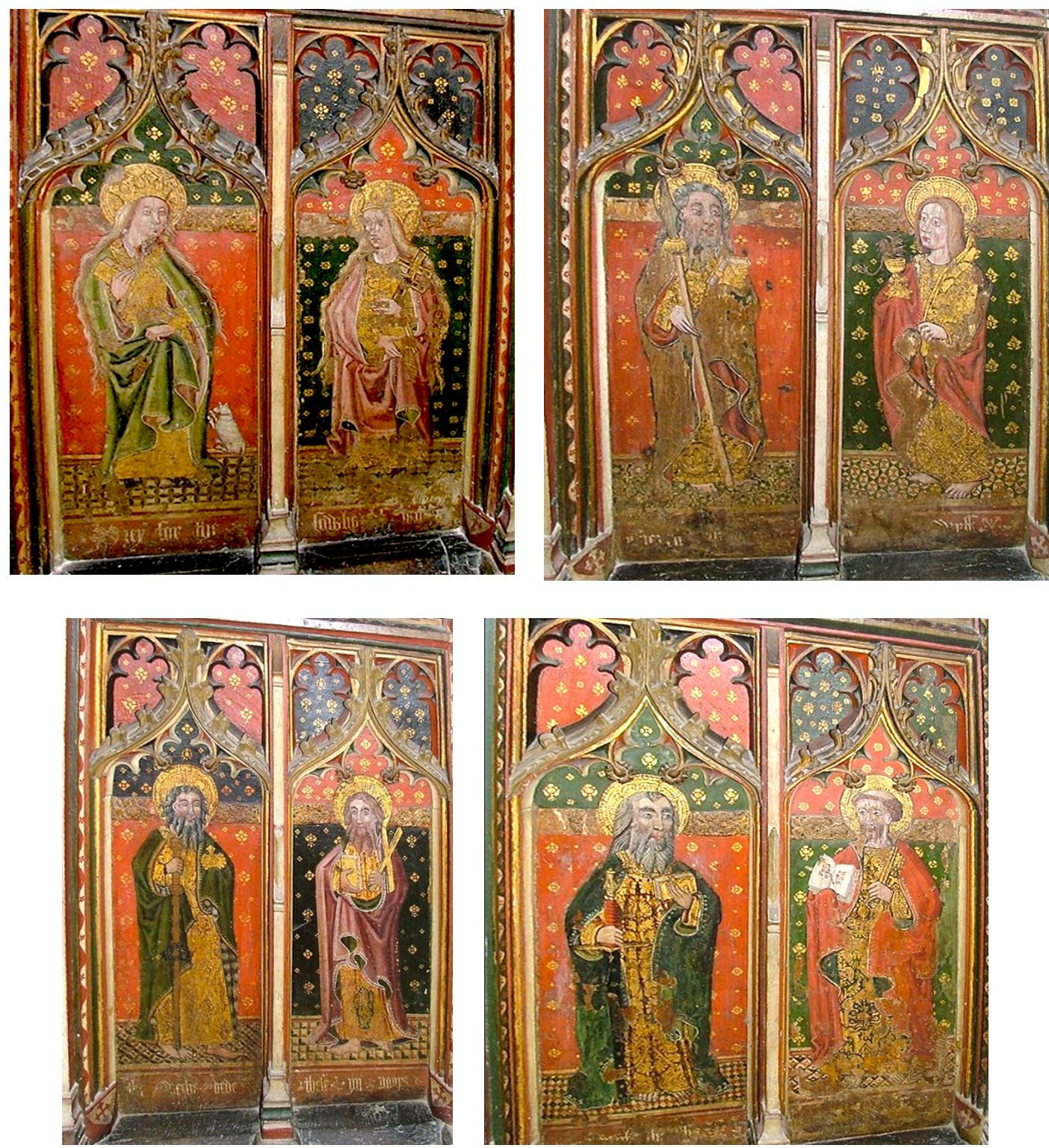

Plate 37: Screen: Cawston. North Side

Left to right: St Agnes, St Helena, St. Thomas, St John the Evangelist, St James, St. Andrew, St. Paul, St. Peter 

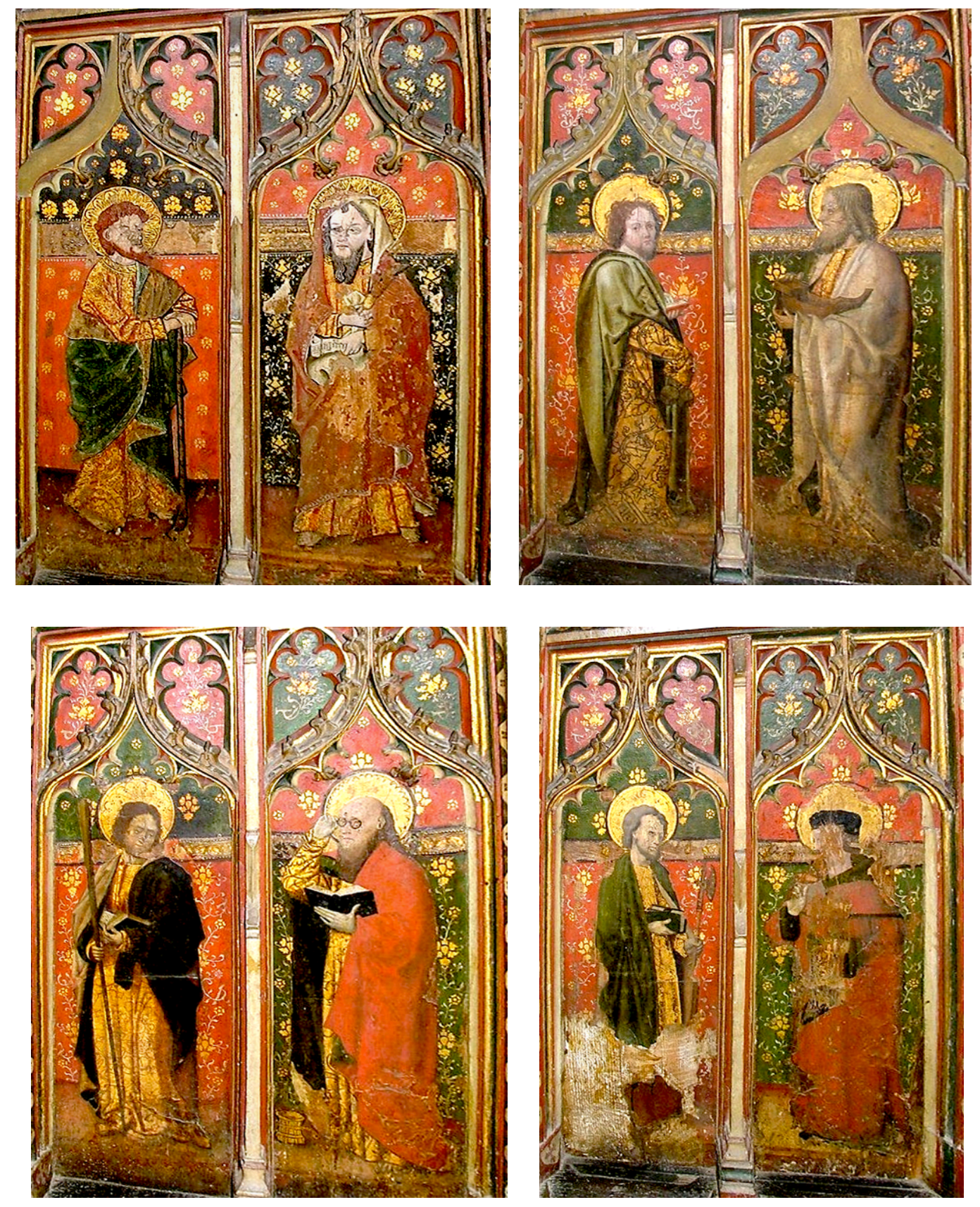

Plate 38: Screen: Cawston. South Side

Left to right: St. James the Less, St. Bartholomew, St Philip, St Jude, St Simon, St Matthew, St Matthias, and Sir John Schorne 

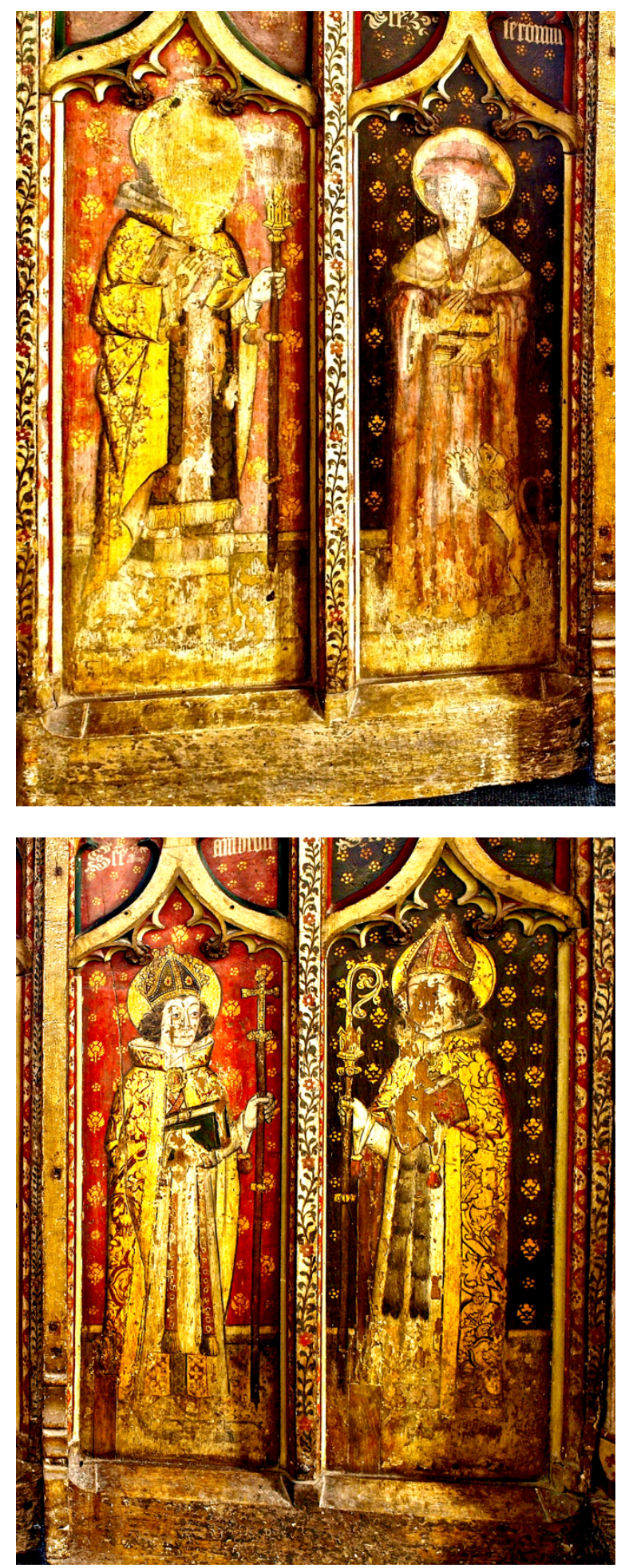

Plate 39: Screen: Cawston. Gates

Latin Doctors 


\section{R-S Sample}

This section will examine two defaced medieval rood screens located in the parishes of Fritton and Garboldisham. Fritton was selected for a combination of its unique donor iconography and selective iconoclasm for extrabiblical images. Garboldisham was also chosen to examine its defaced paintings depicting figures found outside of Scripture.

\section{Case Study: Fritton}

The village of Fritton provides another example of a rural parish that was afforded relative autonomy as the advowson of most the area belonged to the manor at Forcenett, and thus the duke of Norfolk, roughly twenty miles to the west. Blomefield (1806, p. 309) believed that the name of the parish itself, meaning 'free town,' may have been derived from the unusual level of freedom from direct governance this village may have enjoyed. The theological inclination of the populace, served by a church dedicated to St. Catherine, is unclear; however, the list of rectors provides some insight. In 1557, the year before the ascension of Elizabeth, Reginald Nuthall become rector of Fritton; a position he would hold for upwards of the next fifty years along with another parish at Hardwick in 1576 (Blomefield, 1806, pp. 222-23, 311-312). By the end of the century, Nuthall's preface to the Fritton register book went beyond standard honor and respect in his description of the Protestant reign under Elizabeth:

Almightie Jehova Kinge Contynue with multiplication of propserite, honor, and renowne, to the Joye of her Sowle, peace of her Conscience, And terror, and Fear of all her Foes (Rayson, 1864, p. 377).

This reverence for his Protestant sovereign, and reference to Jehova, suggests Nuthall was a progressive who embraced the Reformation and over half a century would move Fritton in this direction. In 1627, a Ralf Smith, whose family has acquired the advowson from the Norfolk family, presented George Cooke as rector. As the first phase of the Reformation had passed by the close of the sixteenth century, the Anglican Church was enduring a prolonged identity crisis as various factions wrestled for the opportunity to shape the nascent church according to their religious standards. Cooke would face a noticeable shift back toward hierarchy and ritual, with the ascension of Laud in 1633 and of Matthew Wren to the bishopric of Norwich in 1635. Within a year 
of Wren taking up his See, Cooke was suspended for not conforming to the rubrics prescribed in the prayer book (Blomefield, 1806, p. 312). The issue extended beyond Wren, who was translated to Ely in 1638, as Cooke attempted to petition the House of Commons to challenge the proceedings he had endured (Bodleian Library, 1860, p. 729). The embattled priest finally capitulated, and was restored to his position which he served throughout the Commonwealth and the Protectorate until 1661 (Anon., 1781, p. 97).

The church, dedicated to St. Catherine, is a magnificent Early English Gothic roundtower structure, which underwent structural renovations in the decades leading up the Reformation; including raising the nave and repairing the roof funded by lands willed in 1502 by a Roger Brown, John Alvard in 1506, and a John Johnson 1510 (Pevsner \& Wilson, 1997, p. 346); (Hart, 1872, p. 5). During this period, a new chancel screen was constructed and adorned to compliment a mural of St. Christopher recently commissioned with additional funds left by Alvard (Plate 39). The screen has twelve panels, with surviving images featured on only eight. The six figures on the northern dado all appear to be the work of Flemish artists dated to around 1510; with spandrels of each panel retaining outstanding carvings of heraldic foliage, unicorns, the Tudor rose and even St. George battling his dragon (Hart, 1872, pp. 3-5). The figures, painted upon alternating red and green backgrounds, are of the male donor kneeling with his eleven sons, his wife kneeling with her three daughters, and the four Latin Doctors. The southern dado features two Apostles, St. Simon with a fish and St. Jude with a boat. While the face of the Simon panel is scratched out, the Jude panel remains undamaged in spite of its apparently strange placement with a later painted block serving as placeholder for the missing gilded spandrels and cusping. Each of the Latin Doctors has damage to the faces, with the extra destructive attention paid to the papal tiara of St. Gregory. The remaining four blank panels were most likely never completed; however, had an Apostolic motif been continued, it is likely St. Peter and St. Paul would have occupied one bay with St. Phillip and St. James in the other. These two pairs both share a feast day on the liturgical calendar, just as Simon and Jude do, resulting in a natural grouping when requiring six apostles in groups of two. 
The donor panels are connected by a scroll decorated with the incomplete text Orate $p$ aiabs, Johi Bac blazoned above the two figures and their fourteen children (Astley, 1907, p. 244). The consensus of existing research is that the donor inscription is a reference to John Bacon (Whiting, 2010, p. 10; Finch, 2000, p. 69; Pevsner \& Wilson, 1999, p. 347); however, there is no record of this family having any connection the parish, as they were in Harleston between 1470 and 1530 and owned land in Pulham and Hardwick (Hart, 1872, pp. 4-5). Another problem with the Bacon identification is the number of depicted children on each memorial. While the eleven figures could represent the two surviving sons and nine predeceased issue, Bacon and his wife Agnes had four daughters as opposed to three depicted behind the mother panel. An alternative possibility is that the inscription is a reference to a John Bacton, whose family had strong martial ties with the Pastons. The connection to Fritton begins with John Paston III, and his wife Margaret, receiving the advowson of the parish. Paston, whose father William was the first cousin with a Bacton through marriage, received a portion of the parish of Bacton in 1503 following the death of a John Bacton in 1500. Without an heir of his own, he left his lands to his son-in-law, John Trovy, who sold these to Richard Calle, who in turn passed the property to Paston, his brother-in-law (Suckling, 1846, pp. 352-359; Richmond, 2002, p. 12). The trouble with the theory stems from the probability that it would be unlikely that his particular Bacton left his ancestral lands to his daughter over his eleven son.

The mystery of this commemoration endures, as the inclusion of a donor on a screen is a very rare phenomenon in Norfolk, where a rich and impressive collection of rood partition artwork was often funded by influential parishioners who never wanted more than perhaps their names to be included at the head or base of a panel. The positioning of the testators, which is consistent with most memorial effigies, is another rarity; as this space was often reserved for saints in conjunction with the broader context of the space featuring a rood cross above. Finally, the use of commemorative decoration within a parish church was often a method employed by new families to legitimize their rise in society (Finch, 2000); (Llewellyn 2001). The strong Catholic iconography laced throughout this commemoration, from the rosary beads held by the figures to purgatorial implications of the text, suggests the desire to establish a lasting connection with the living of the parish (Duffy, 2004, p. 334). Yet, the absence of any definitive 
connection between John Bacon, or Bacton, with Fritton, reveals a complex geopolitical landscape where even extended ties between a lord and a parish could be enough for the creation and subsequent endurance of a commemoration.
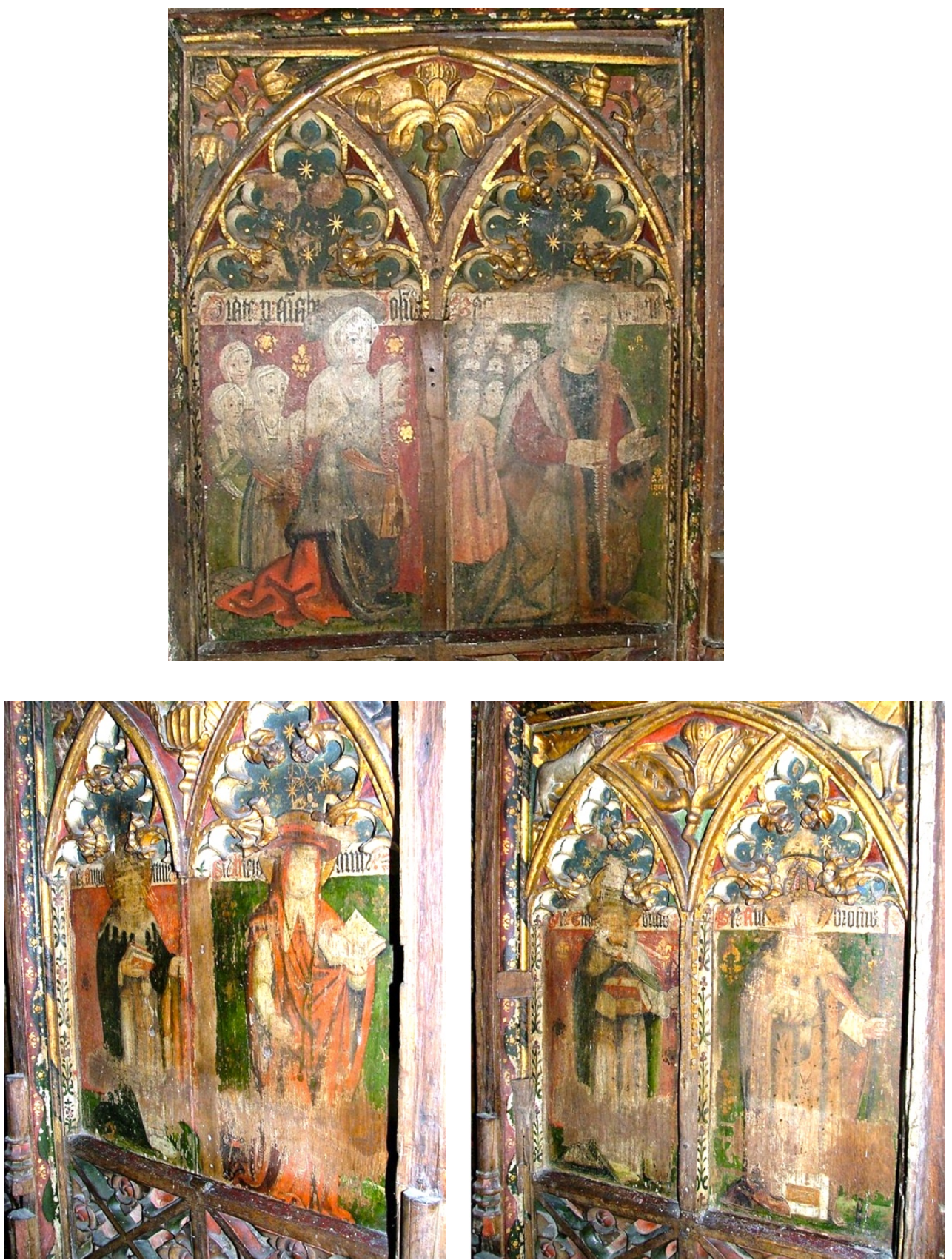

Plate 40: Screen: Fritton

Left to right: Donor and family, Augustine, Jerome, Gregory and Ambrose.

(Photo by: Simon Knott) 


\section{Case Study: Garboldisham}

Garboldisham provides another exemple of a village, served by two parish churches, which was dominated by the secular influence of five manors and four tenements. The chief manor was held by the Benedictine order at Ely until 1045 when the abbot, Wulfric, consigned this manor, and several others, to his brother, Gudmund, to facilitate his marriage to a nobleman's daughter. This unusual arrangement was designed as a temporary measure, as the lands would revert to Ely upon Gudmund's death; however, the subsequent Norman invasion saw the manor seized by Hugh de Montfort, which prevented holdings from ever returning to the monks (Blomefield, 1805, p. 255). This manor held a portion of the advowson of a church dedicated to St. John the Baptist, which the de Montfort manor chose to share with Bermondsey Abbey in Surrey; perhaps to honor their past Benedictine connections. In 1280, this stake was joined to that of a nearby church, dedicated to All Saints, which was already held by the earls of Norfolk at Bois's Hall. In spite of having its tower rebuilt in the fourteenth century, All Saints was declared the subordinate institution in 1433 to St. John the Baptist for all sacraments and upkeep of the clergy house; although, the rectors were instructed to maintain the chancel and conduct a weekly service.

The northern aisle of St. John the Baptist features an oak dado that was originally a part of the crossing screen installed at All Saints (Plate 40). In 1734, upon the instigation of the parishioners, this church was formally closed. This saw the removal of the roof; with all furnishings either being moved or sold for beautification of the remaining church. The upper portion of the screen is a Victorian innovation, suggesting the dado was either stored or only partially installed until the following century. The four open panels, featuring modest carvings or spandrels, each feature a painted representation, with St. Germanus and St William of York on the northern side of the opening and St. Mary Magdalene and St. Agnes to the south. These images were provided at the expense of William and Catherine Bole, who commissioned these panels with the instruction to pray for the welfare inscribed (Blomefield, 1805; Duffy, 2012, p. 64). While William died in 1504 (Cotton, 1987, p. 48), the nature of the vernacular suggests that the couple may have still been living; a type of commemoration found as far back as 1311, Sir John de Thorpe established a chantry chapel at Little Massingham, found 
in the $R-N W$ sample, designed to say mass for his ancestors and for the present welfare of himself and his wife (McLeod, 1882, p. 16).

The saints illustrated here, three extra-biblical and one controversial from the New Testament, all show traces of deliberate damage across the faces. While all four are unusual screen images, the St. Germanus, a fourth-century bishop of Auxerre, panel is an especially rare piece of iconography; in spite of his prominent role in late Roman Britain, challenging Pelagian heresy and advancing of the Cult of St. Alban. It should be noted that the facial mutilation on this panel, even with the Mass vestments and crozier (Nichols, 2002, p. 200), is significantly less than the other three figures. The other figure entwined with a local tradition, St. William, is another atypical choice for a screen. This saint, depicted with the mitre and crozier of an archbishop is most commonly found in Yorkshire windows, such as a lost version at Walpole St. Peter (King, 2006, p. 106). The remaining female saints, Mary Magdalene and Agnes, with the latter identified as holding a palm and having lamb at her feet (Nichols, 2002, p. 162). Yet, a closer examination of the damaged painting reveals the creature at her feet is covered in scales; this suggests that the images are actually of St. Margaret of Antioch with Satan as a dragon. 

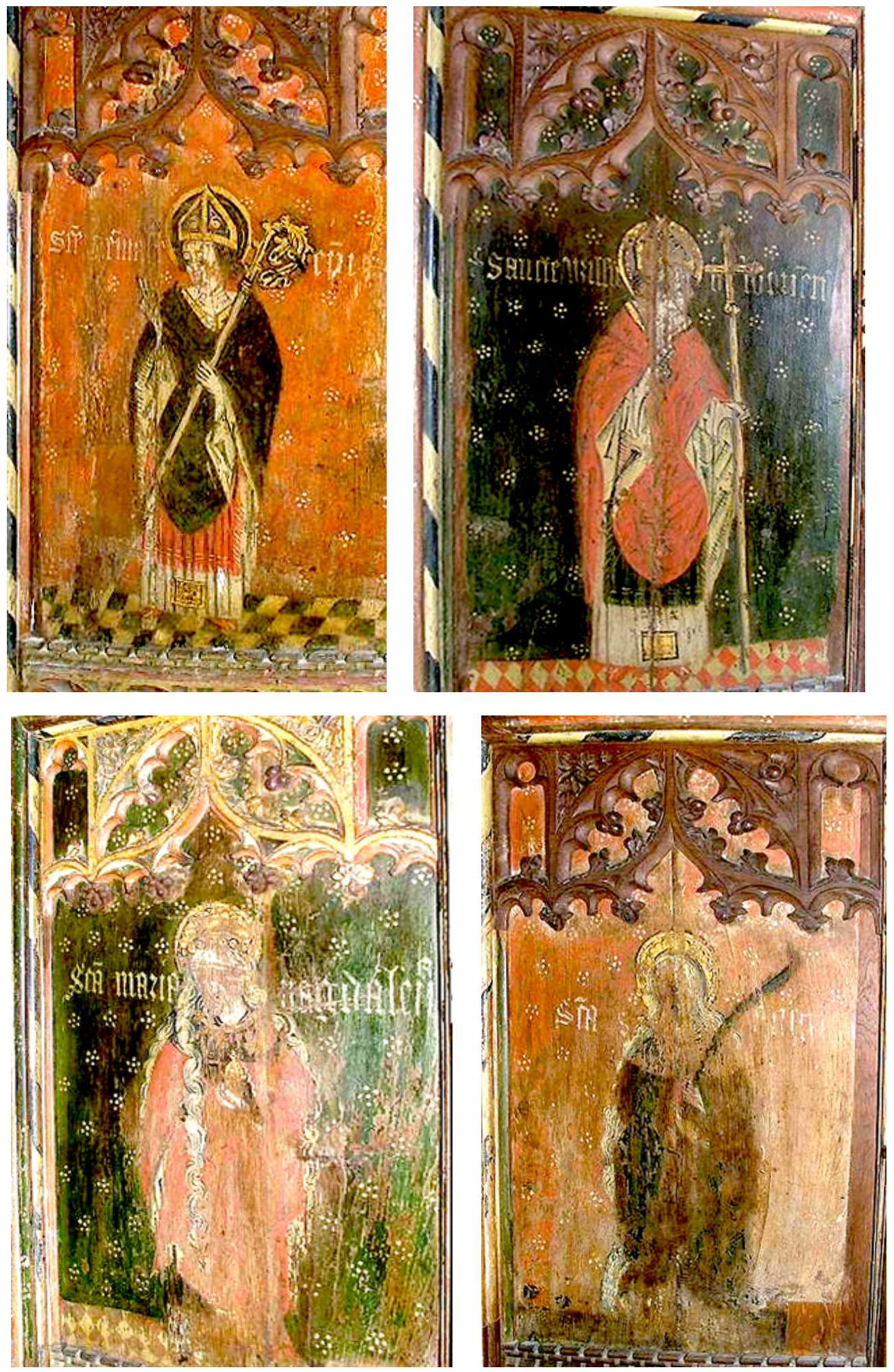

Plate 41: Screen: Garboldisham

St Germanus, St William of York, St Mary Magdalene, St Agnes 


\section{U-N Sample}

This group will examine a single case located in the parish in Norwich of St.

Augustine. While the rood screen itself has been lost, a single defaced panel of a popular extrabiblical saint has survived.

\section{Case Study: Norwich: St. Augustine}

The parish of St. Augustine, located in the small ward of Colegate in northern Norwich, is first mentioned in a twelfth-century correspondence between the bishop of Norwich and the Augustinian prior of Llanthony Secunda in Gloucester (Smith, et al., 1980, pp. 343-346 ). The namesake is unique as this church is the only of its kind in Norwich, which could be in remembrance of either the sixth-century archbishop of Canterbury or the more notable fifth century bishop of Hippo and Latin Doctor. The post-Norman period saw this church under the patronage of the aforementioned Augustinian house, which Blomefield (1806, p. 475) incorrectly identifies as Lenton Priory; however, his subsequent account of the advowson being passed on to Norwich Priory identifies the prior as Bartholomew, who served Llanthony Secunda in 1262. In spite of these monastic connections, the church was better served by their wealthy parishioners, including weavers, carpenters, and millwrights, who funded the extensive rebuilding in exchange for a chance to buried within the structure (Blomefield, 1806, pp. 474-476).

There can be no doubt that the renovated church received a new chancel screen during this period, complete with painted panels depicted various saints (Plate 41). At some point during the extended Reformation, this screen was demolished and completely extracted from the building. While the details of this destruction are unknown, the surviving remains provide clues to the chronology of this fitting. A single panel from the original screen, depicting St. Apollonia, has survived and was reset in the northern aisle until moved to storage in recent times (Mortlock \& Roberts, 2007). This saint was a third-century martyr, whose execution included having her teeth violently plucked from her mouth; this is the reason she came to be venerated as the patroness of dentistry. This panel features modest ornamentation, including paintwork designed to look like woodcarvings and arches; not an unusual discovery when considering the economic status of this parish's benefactors. At some stage during the Reformation, perhaps as a result of the Edwardian injunctions, the face of this figure (and presumably 
of those that did not survive) was scratched out. This suggests an initial phase of iconoclasm that predates the subsequent destruction, which may not have occurred until the destructive excesses of the following century. The use of Apollonia suggests that the lost panels may have also featured extra-biblical saints, an offense that began with defacement and culminated in annihilation. It should be noted that this panel is one of only eight examples of Apollonia remaining in any Norfolk church, usually seen in glass or on other screen panels, such as at Barton Turf. The scarce survival rate of such a popular extra-biblical depiction, one who promised relief from the frustrations and pain associated with poor dentistry, demonstrates that the visual depiction of these figures from Christian history was no longer deemed appropriate for display. The threshold for what was considered 'acceptable' was clearly far stricter in Norwich than

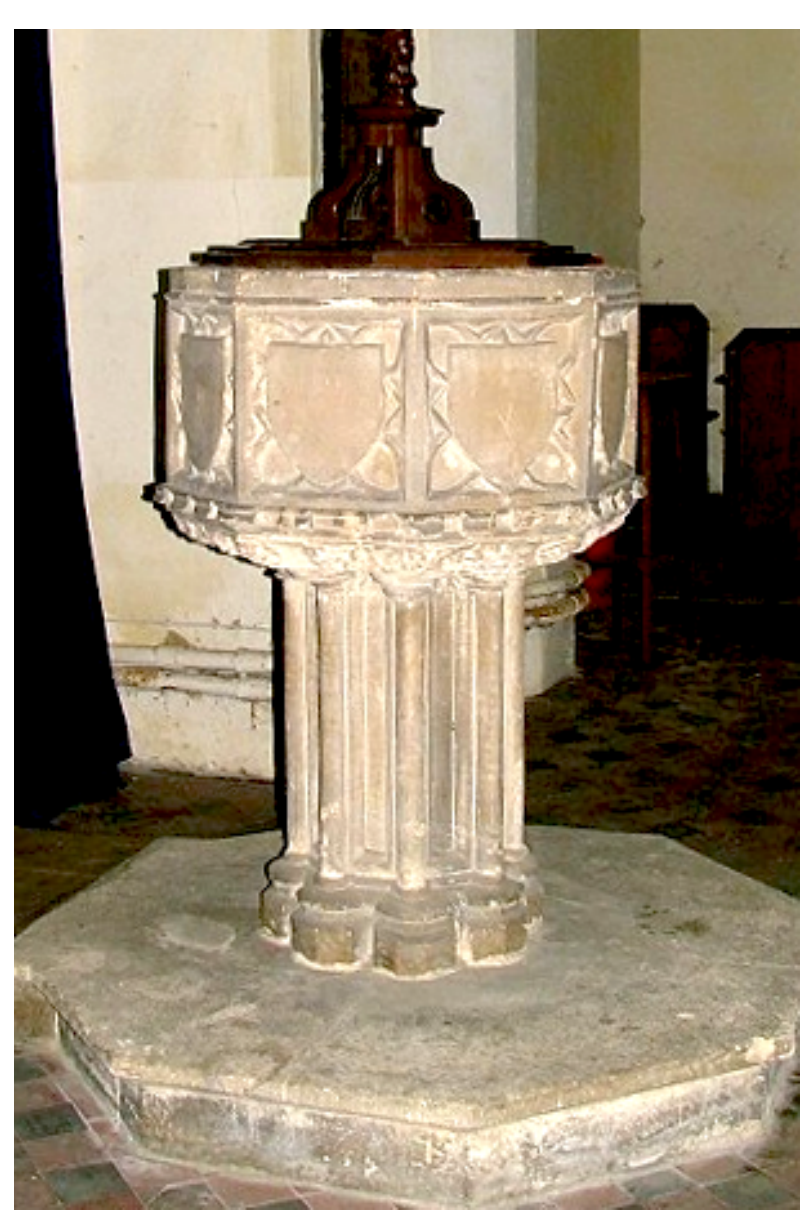

Plate 42: Screen: Norwich St Augustine the rural samples, as only four chancel screens survived in any form from the entire sample. It can also be speculated that the personal connection many parishioners must have felt for Apollonia culminated in this image being hidden and spared, in spite of the previous damage it has already endured. This a clear reminder that a single individual is all it would require to rescue a piece of iconography; while the destruction of parish property would require either a community consensus or the intrusion of an official visitation. 


\subsection{Paintings - Wall \& Ceiling}

Acts of iconoclasm against medieval polychromy during the Reformation are far harder to identify than the previously discussed church fittings, as the preferred method of destruction would ironically provide salvation for many of these images in the subsequent centuries. While the Henrician phase of the Reformation targeted selective icons, like Thomas Becket, while promoting the use of Royal Arms, the subsequent Edwardian period extended the religious reform far beyond issues of personal importance to the monarch. In 1547, all images connected with 'feigned miracles, pilgrimages, idolatry and superstition' were commanded to be removed with haste (Frere, 2016; Rosewell, 2008, p. 75). For frescoes, the solution did not necessarily require any deliberate acts of destruction, as these visual schemes could be easily covered by several coats of whitewash. This was a perfectly acceptable solution, and simple path to compliance, as for the more enthusiastic reformers, an image could be defaced first and then thoroughly purged by an unrelenting entropy of whiteness. Meanwhile, the more reluctant conformists could restrict the number of coats they applied and take assurance that their sacred images were actually be preserved for an eventual restoration. In regards to the latter, entire parishes did indeed begin to report that medieval wall paintings were starting to bleed through the whitewash and text as early as the 1570s (Litzenberger, 1997, p. 113), similar to a series of rood dado panels at Binham which will be discussed in the following chapter.

\section{Case Study: Norwich Cathedral}

Norwich Cathedral retains a rare case of medieval polychromy with evidence for targeted iconoclasm interestingly enough sprawled across the arches that served as the entrance to a lost chapel devoted to storage and display of relics (Plate 42). Originally constructed towards the end of the thirteenth century, this ante-reliquary, or sub reliquiis, was extended during the bishopric of John Wakering (1416 - 1425) and adorned with a variation of his traditional heraldry featuring a pelican motif, symbolizing Christ, as opposed to his traditional use of three hawks (Park \& Howard, 1996, p. 392). This bridge would have provided an opportunity for relics to be displayed at a safe distance, as pilgrims processed beneath through what must have been the Easter sepulcher (Ditchfield, 1902, p. 410). The vaults in this bay, which can be very easily observed due to the elevated nature of the chapel, are adorned with four 
frescoes, each features a trio of figures set against a backdrop of vines that create a visual cohesion across the entire ceiling. There can be no doubt that this pattern is meant to evoke the biblical reference of John 15.5; "I am the vine, ye are the branches: He that abideth in me, and I in him, the same bringeth forth much fruit for without me ye can do nothing." The branches, in this case, are divided into four categories: apostles, martyrs, confessors and virgins, all presented in a French art style which may have influenced later polychromy at Westminster (Pevsner \& Wilson, 1997, p. 67).

The eastern portion of the vault features St. Andrew and St. Paul flanking St. Peter, and represent the only complete grouping to feature figures from the Bible. The western segment pays homage to prominent female virgins, as the Blessed Virgin, with Child, is flanked by both St. Margaret and St. Catherine. While polychromy of this set is in excellent condition, the faces are missing and appear to have been filled in. The northern space of the vault depicts the confessors: St. Nicholas surrounded by St. Martin and St Richard of Chichester. The latter, although faded and defaced like the other, is in the best condition; possibly his inclusion was a result of his connection to Walter Suffield, bishop of Norwich, who was a contemporary of Richard and beneficiary of a serpent tongue relic, which must have been a prominent part of the collection (Park \& Howard, 1996, p. 396). Finally, the heavily damaged southern portion retains traces of three martyrs: St. Lawrence flanked by St. Edmund and a bishop, who appears to be the highly offensive Thomas Becket. While the damage to the faces of this trio appears to be deliberate, the lower portion stripped of all of its paints appears to be wear.

This incredibly deliberate censoring of extrabiblical iconography should come as no surprise at a site influenced by a learned presence, as the former priory continued to exist at the Cathedral in the form of a secular college. The canons would be in a position to both distinguish which saints were from scripture and the emerging Protestant imperative that valued the distinction. The remnants of the images, in a portion of the building formerly dedicated to relics, one of the most abused components of medieval religion, made a far stronger statement as a visual reminder of the conquest of biblical truth over false superstitions (Aston, 2003, pp. 9-28). 

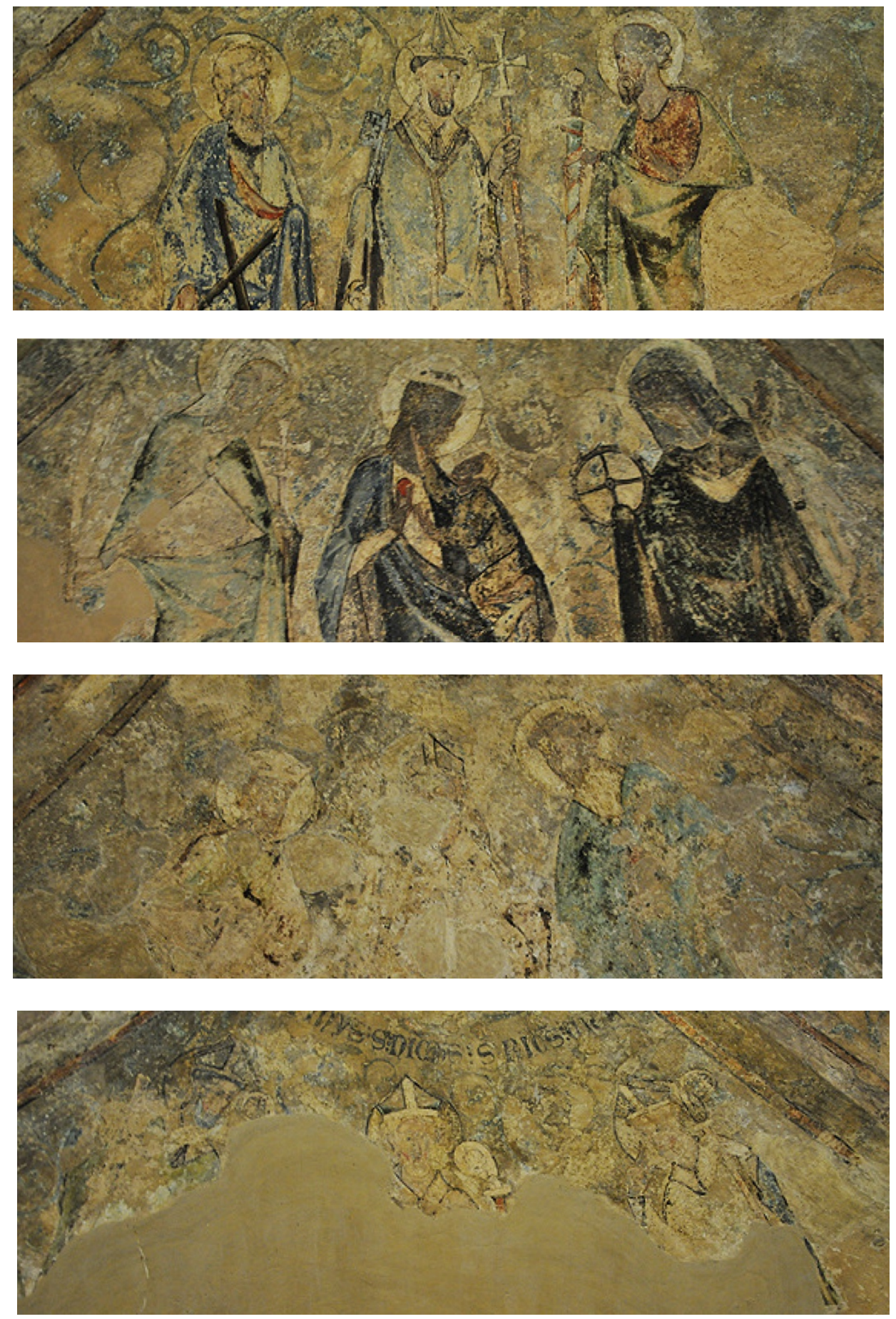

Plate 43: Wall Painting: Norwich Cathedral. Ante-Reliquary Chapel

St. Andrew, St. Peter, St. Paul (top); St. Margaret, the Virgin with Child, St.

Catherine (upper middle); St. Martin, St. Nicolas, St. Richard (lower middle); St

Thomas Becket, St. Stephen (?) or St. Lawrence (?), St. Edmund (bottom). 
Norwich Cathedral retains an excellent example of a defaced panel painting. In St. Andrew's chapel off of the north transept, a late-fourteenth century wood panel painting of the Crucifixion is on display. It has been speculated that this icon, in conjunction with a panel of the Betrayal displayed in the Visitors' Centre, were part of an elaborate altarpiece at the parish church of St. Michael-at-Plea (Pevsner \& Wilson, 1997, p. 211). During the Reformation, this painting was selectively defaced with the faces of the two donors kneeling at the foot of the cross scratched out, with the portion of the panels featuring Christ being spared any damage. This demonstrates that transformation of relationship between an image and viewer, as paintings like this were valuable for their expression of a historical event accounted in Scripture. The paradoxical integration of these two donors into the scene was not tolerated, which further reveals an intelligence demonstrated in certain example of iconoclasm. (Ladick, 2011, p. 46).

\section{Case Study: St. Christopher}

The most common iconographic depiction found in surviving medieval polychromy is that of St. Christopher, the pseudo-historical Catholic saint revered for fording across a river with the Christ child on his shoulders. Despite never being officially canonized, the man who inspired the legend, possibly named Reprobus, maintained the moniker of Christopher, or Christ-bearer. Evidence for 20 instances of his image can still be seen across all four sample groups; with four in $R-N W$ group, five in the $R-S$ group and astounding ten in the $R-N E$ group. The collection alone represents about $15 \%$ of the 183 known representation of St. Christopher on display in parish churches across all England (Collier, 1904, p. 130). This figure was a crucial focal point for veneration in medieval Christianity for protection from death, either resulting from an accident or illness. In a society ravaged by epidemics, the importance of such a safeguard was just as important as the focus placed on death itself, as discussed in the previous chapter. This patronage, which evolved into the more modern association with protection for travellers, was central enough to the life of common parishioners, that this image was often placed on the north wall of the church to ensure it would be seen upon entering the building through the south door. Across Norfolk sample groups, this is the case for 16 of the 20 instances, where the remaining cases at Sedgeford, Crostwick, Attleborough and Great Ellingham all feature a northern entrance possibly resulting from early settlement patterns. 


\section{Case Study: Hardwick}

The faded fourteenth century mural of St. Christopher, carrying the Christ child, is located on the north wall of St Margaret at Hardwick (Plate 43). While the diminutive depiction of Christ remains in good, albeit aged, condition, St. Christopher has a swatch of his face missing in a deliberate act of iconoclasm. The damage inflicted on an already washed out image is made far more clear in a watercolor reproduction provided

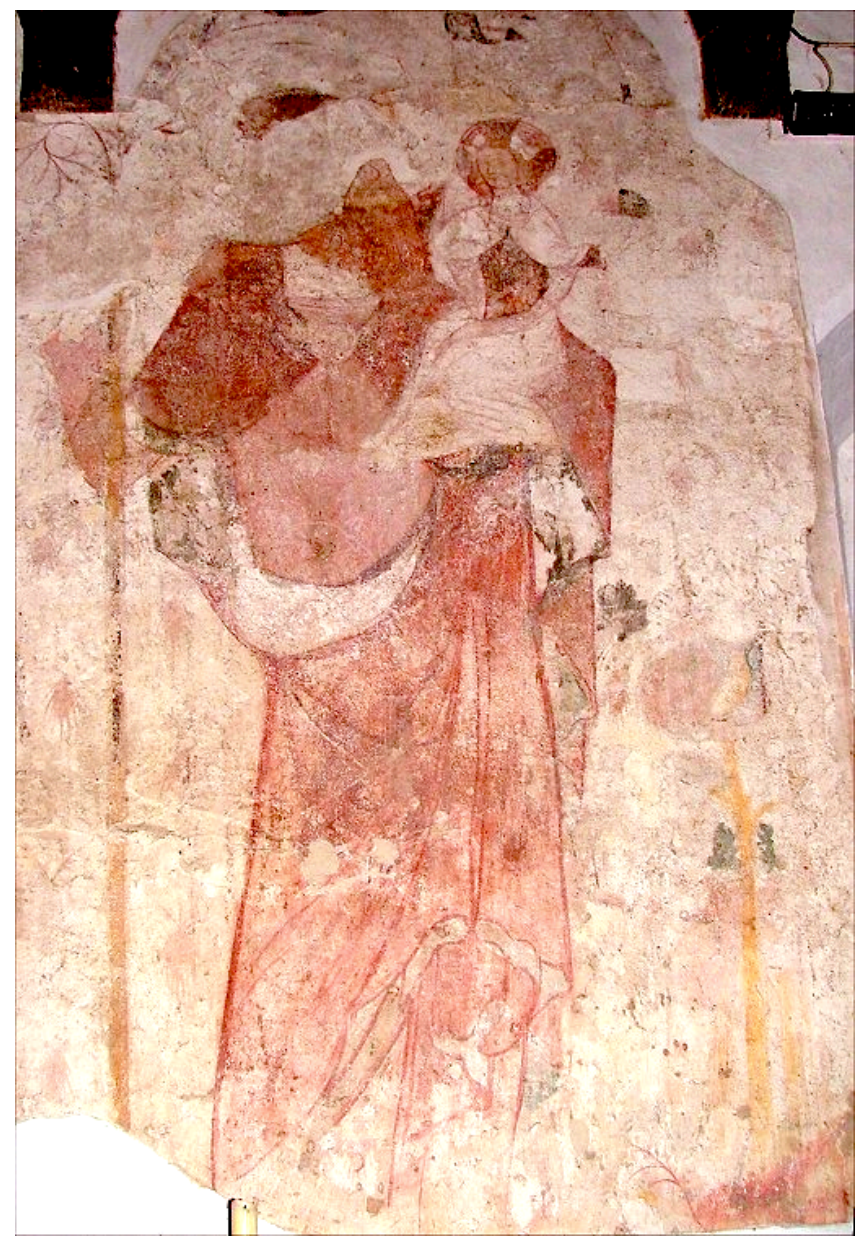

Plate 44: Wall Painting: Harwick by Blomefield (1801 in Brindley 1929). This representation, most likely inspired by an found within the De Lisle Hours manuscript (Pridgeon, 2008, pp. 220-222), is set atop a backdrop of birds and an owl. The deliberate targeted of this saint's face, while sparing the extrabiblical image of Jesus, may have been performed either during or in lieu of, any whitewashing undertaken. Either way, the dramatic restraint in selective acts of iconoclasm continues to reinforce the trend being outlined in this study.

\section{St. Christopher}




\section{Case Study: Donors}

At All Saints in Cockthorpe, the traces of a mural of St. Christopher on the north wall of the nave were recently uncovered beneath the Reformation whitewash (Plate 44; Pevsner \& Wilson, 1997, p. 437), a prime location as it would be viewed by all parishioners entering from the south entrance. From what remains of this image, the bottom portion features two miniature kneeling figures, one male, and one female. The incorporation of these donors into such a central piece of iconography suggests that they were a prominent family within the parish, as such an inclusion indicates that they desired the continuous prayers of the living as future generations gazed upon the grand image upon entering the church (Rosewell, 2008, p. 59). It is possible that these donors are Richard Calthorpe (d. 1438) and his wife Margaret Ermingland (d. 1478), as the latter ordered her body be placed near her husband within the church and for a chaplain to offers prayers for their souls (Blomefield, 1808, pp. 215-18).

The inclusion of donor memorialization in conjunction with an early sixteenth-century image of St. Christopher must have been the medieval incarnation of modern day sponsorship marketing; as the perpetual commemoration, fueled by the laity, could provide all the benefits to a soul that a chantry could provide at a fraction of the

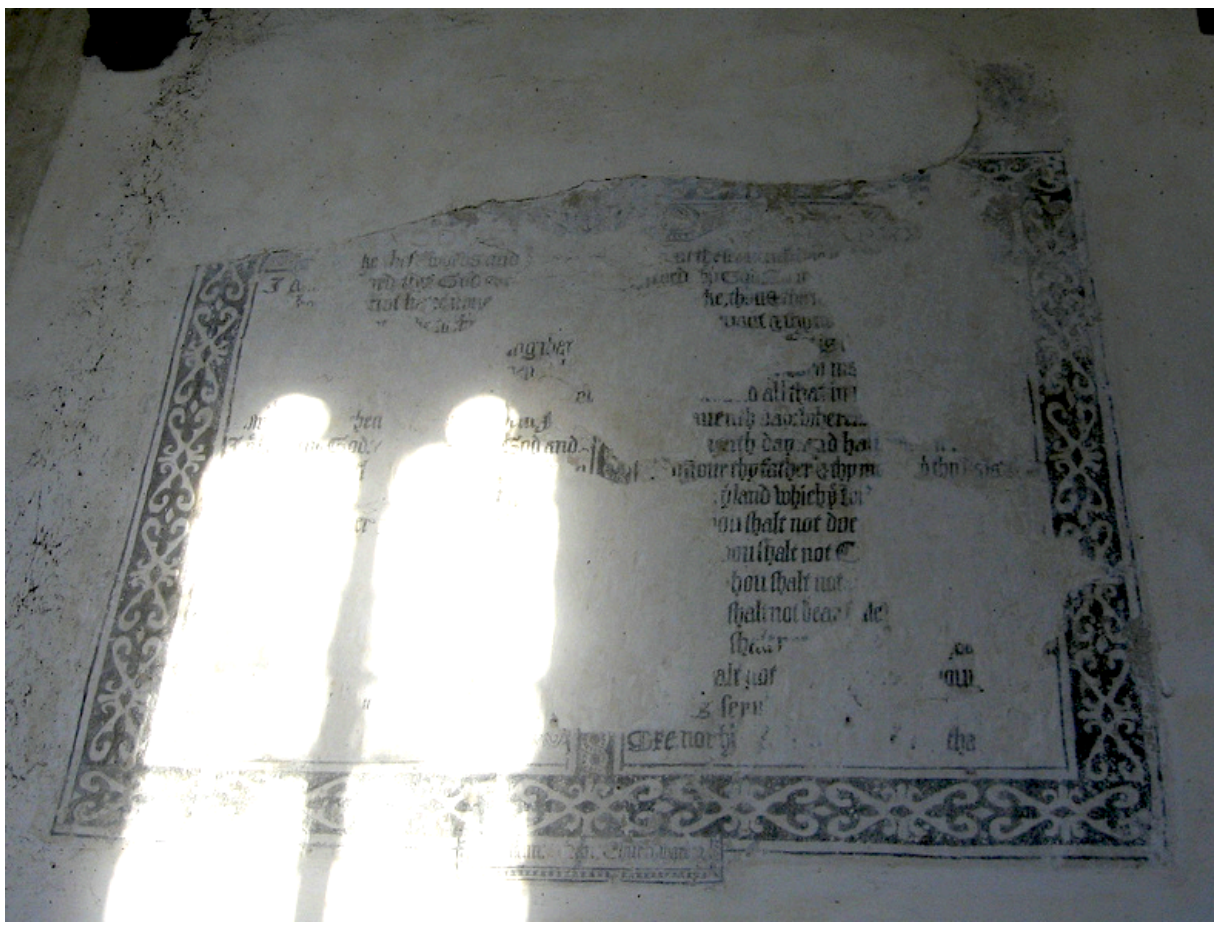

Plate 45: Wall Painting: Cockthorpe 
endowment. At St. Catherine in Fritton, traces of yet another St. Christopher painting can be identified on the north wall of the nave. It is probable that this polychromy, and another depicting St. George and the dragon on the northeast wall, was funded by the Alward family. The faint traces of two kneeling figures, as we observed in Cockthorpe, can still be seen along with an even fainter inscription identifying both John Alward (d. 1506) and his wife. His will allocated a portion of his land holding in a trust for the sole purpose of maintaining his parish church in Fritton (White, 1854, p. 354; Hempnall Group of Parishes, n.d.).

These murals provide an opportunity to address a fundamental truth regarding medieval iconography; the benefits reaped from the veneration of saints were intimately linked to visually experiencing a depiction. This passive approach, as opposed to a more assertive financial contribution, cast the widest net for parishioners to be blessed. As a result, the location and size of an image played an integral role

\subsection{Sculptures}

This section will build upon the case study in Chapter IV and examine the sculpted roof bosses found at Norwich Cathedral that fell victim to deliberates acts of iconoclasm.

\section{Case Study: Norwich Cathedral Roof Bosses}

At Norwich Cathedral, acts of iconoclasm inflicted upon roof bosses only appear scattered amongst the collection found within the cloisters (Plate 45-46). While deliberate destruction must have played a role in the partial destruction of the sculptures, the rigors of time and the elements could also be responsible, as the cloister walk is essentially outdoors. Furthermore, the most common form of damage as a result of neglect or disrepair is the loss of a sculpture's appendages, such as the head, which was the most common method of vandalism employed by iconoclasts following the Reformation. As a result, it is difficult to draw any absolute conclusions regarding why certain icons have endured, and others have not; however, an interesting trend does begin to emerge amongst the uncompromised keystones. 
While $14 \%$ of the cloister bosses depicting stories from the Bible, including the Revelation cycle, show traces of damage, the rate increases drastically to $52 \%$ for those featuring extrabiblical saints or legends. This rate is consistent across the Biblical sample, even when examining the Apocalypse group separately from other New Testament narratives. In addition, sculptures depicting the evangelists, most notably St. John, and Old Testament figures, like Moses and Samson, are scattering amongst the collection. The remaining decorative bosses, the foliage, grotesques, and lions, do not show any significant signs of damage beyond basic wear.

In spite of being the oldest figurative sculptures in the cloister, the series of bosses focused on the life of Christ in the east walk have the lowest rate of damage of all figurative sculptures in this part of the building complex. Only 28\% (9 of 32) of bosses featuring Christ show signs of iconoclasm, with the damage, always confined to other figures in the image, such as the Virgin or figures surrounding Christ enthroned in the Apocalypse series. This set includes central bosses of the Passion of the Christ across three bosses and the Resurrection and Harrowing of Hell across another two. In each case, the figures retain their heads and decorative integrity (with the exception of the original paint which has been lost to time, weather, and moisture as a result of repainting directed by E.W. Tristram in 1936-39; in Rose, 1996, p. 368). This trend continues into the north walk with undamaged bosses of the sealing of the tomb (Matthew 27.62.66), Jesus with Mary Magdalene following the Resurrection (John 20.17), and Christ eating breakfast with his disciples (John 21.12-13). An additional post-Resurrection boss depicting the Ascension has selective defacement of the female witnesses in the group which will be examined in the following chapter. In addition to these, the bosses depicting foliage and animals appear to have emerged relatively untouched. The cloister vault bosses fall into the first category for survival by not offending the theological imperative of the reformers. It is apparent that these icons could have been easily disfigured during any wave of iconoclasm during the sixteenth and seventeenth century. It appears; however, that the scriptural basis for the icons, perhaps combined with an enduring spatial reverence for the easternmost spaces, played a crucial role in their survival (Ladick, 2011, pp. 33-34). 
The selective destruction of extrabiblical vault bosses around the cloister appears to have been calculated and deliberate. Despite the head being one of the most vulnerable components of sculpture, a series of trends emerge when the nature of the defaced keystones is assessed in comparison with the survivals discussed in the previous chapter. In the east walk, a boss depicting the Ascension has the heads of all of the women in the depiction removed, which was possibly a tactic employed to assure the visage of the Virgin was defaced. This trend continues, as 53\% (9 of 17) of bosses featuring the Virgin feature signs of iconoclasm. This includes the Coronation and the medieval sermon tale of the Jew of Bourges, where a young Jewish boy was thrown into a furnace for taking mass and was saved by the Virgin (Rose, 2015). In addition, another boss depicts Mary surrounded by the twelve apostles, with four of the 12 men missing their heads, while the headless Virgin is flanked by eight undamaged figures. Another controversial extrabiblical saint, St. Thomas of Canterbury, shows damage on all four occurrences, which is consistent with the anti-Thomas component of the Reformation beginning during the reign of Henry VIII. While it is difficult to determine the nature of the damage definitively, the results do suggest a higher concentration of destruction on bosses dedicated to the veneration of strong Catholic doctrine, such as the Marian portrayals; or post-biblical events, like St. Basil, St. Julian, St. Giles, St. Catherine or unidentified bishops. 


\begin{tabular}{|l|r|r|r|}
\hline & Bosses & Damaged & Rate \\
\hline Biblical & $(\boldsymbol{f})$ & $(\boldsymbol{d})$ & $(\boldsymbol{f}) \boldsymbol{i})$ \\
\hline Extrabiblical & 142 & 20 & $14 \%$ \\
\hline Foliage & 48 & 25 & $52 \%$ \\
\hline Other & 118 & 2 & $2 \%$ \\
\hline & 85 & 1 & $1 \%$ \\
\hline TOTAL & & & \\
\hline
\end{tabular}

Table 17: Roof Bosses at Norwich Cathedral: Iconoclasm

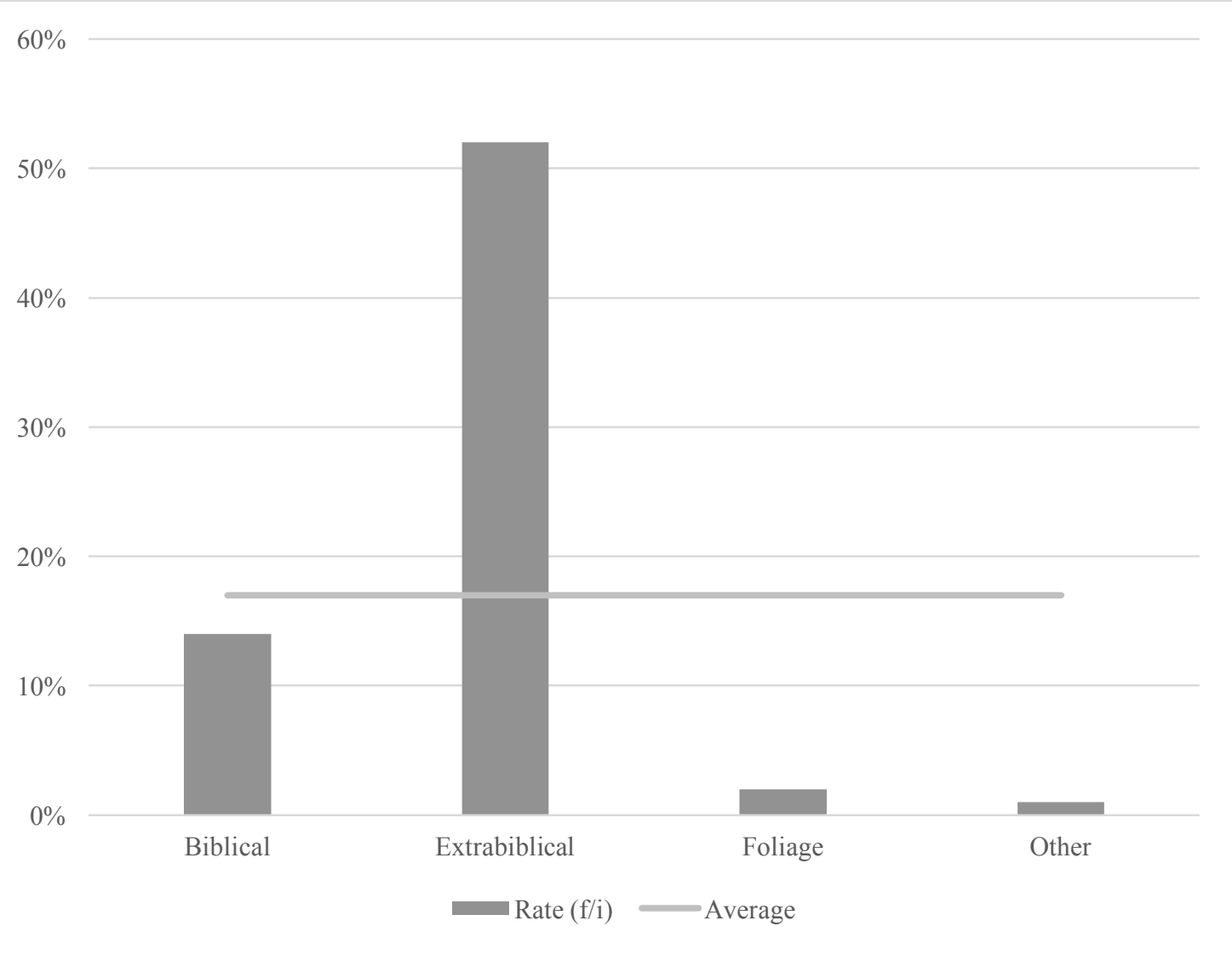

Figure 16: Roof Bosses at Norwich Cathedral: Rate of Iconoclasm 

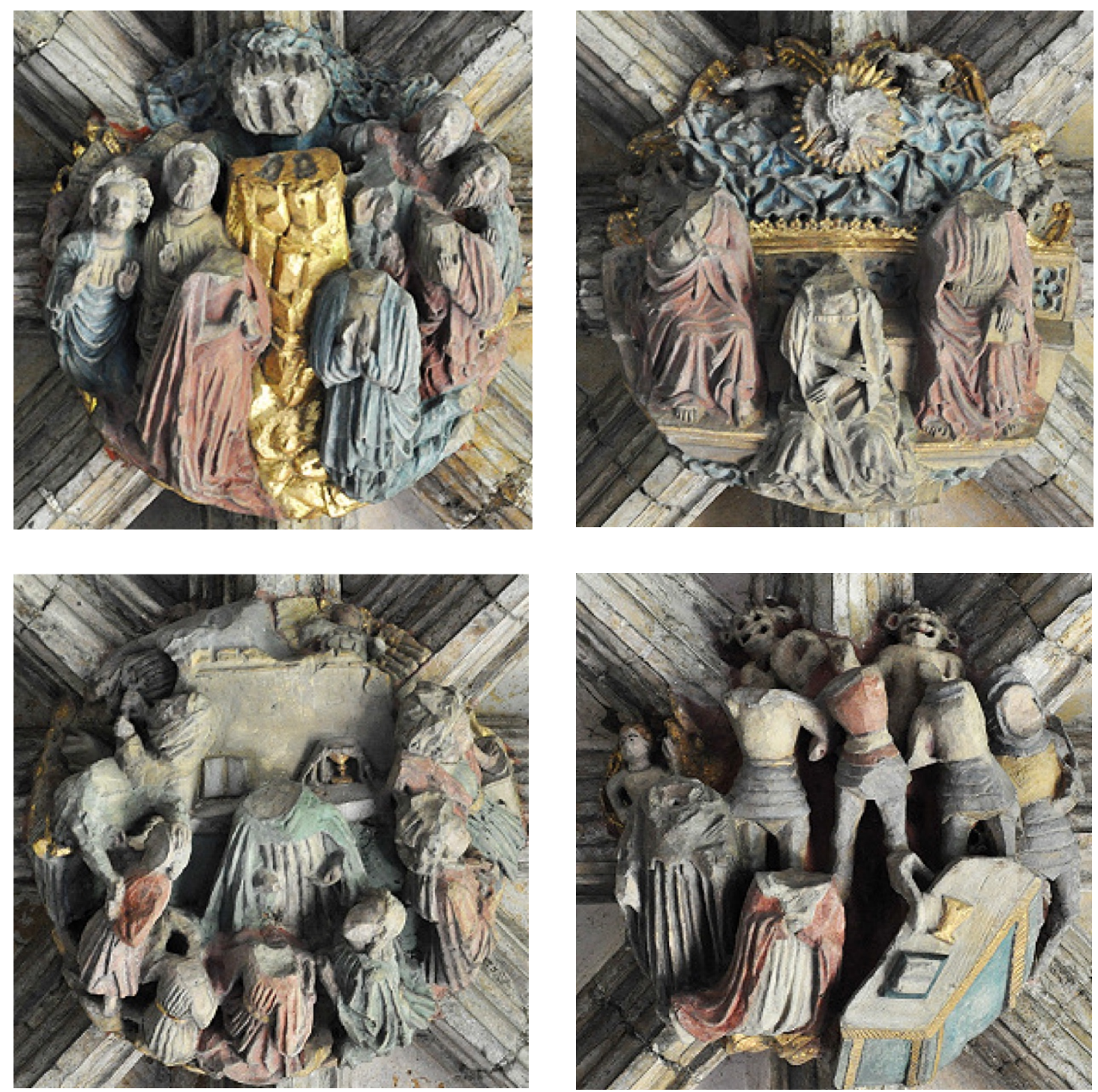

Plate 46: Sculptures: Norwich Cathedral Cloister. Part One - Damaged 

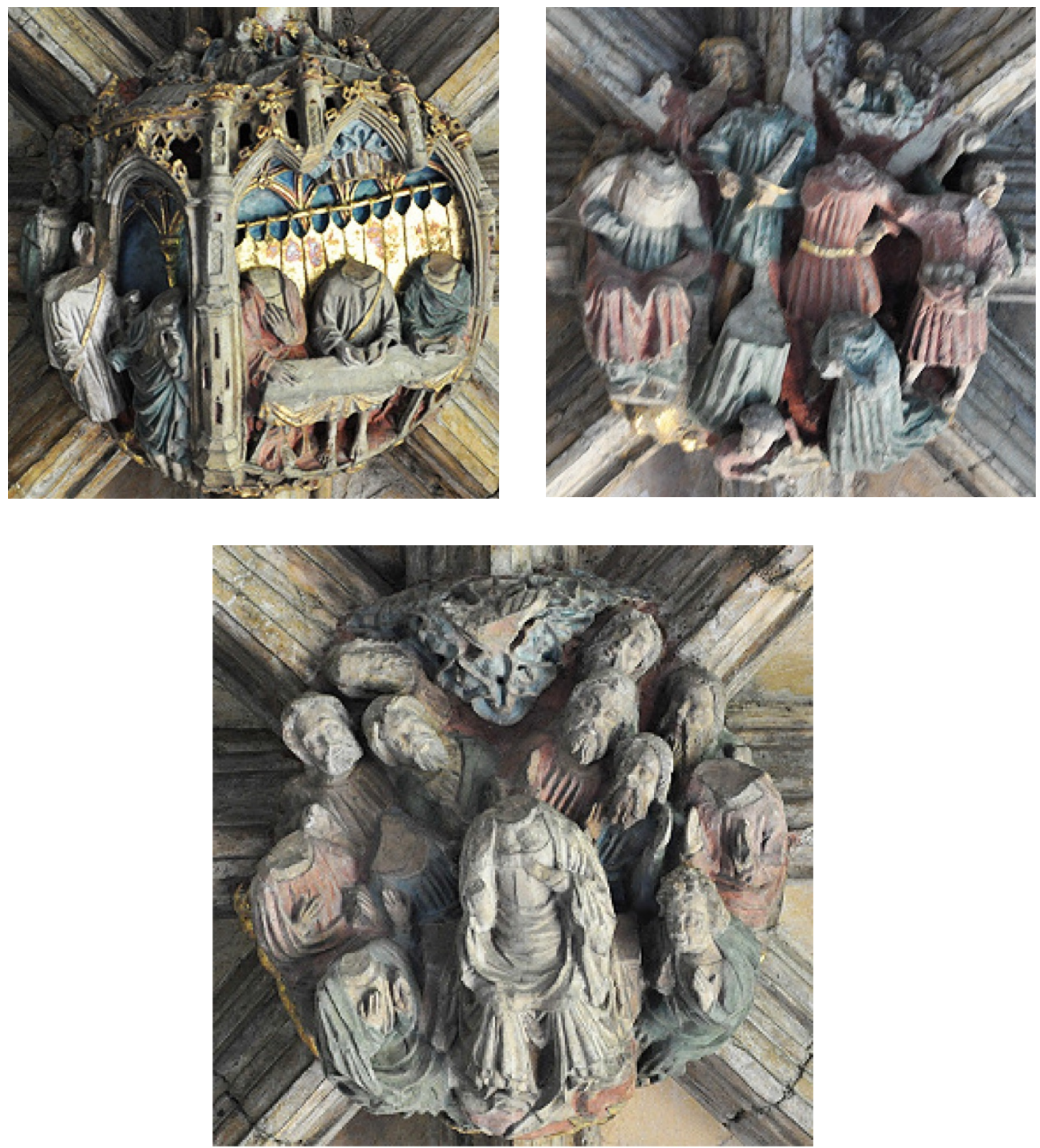

Plate 47: Sculptures: Norwich Cathedral Cloister. Part Two - Damaged

Plate 46. Ascension; Coronation of the Virgin;

Virgin and the Jews of Bourges; St. Thomas \& knights

Plate 46. Supper at Emmaus; stoning of St. Stephen;

the headless Virgin surrounded by the Twelve. 


\subsection{Conclusion}

The rate of destruction for extrabiblical iconography found on church fittings examined across the four samples groups in this chapter is irrefutable, as selective and intelligent iconoclasm was taking place. This suggests a far more sophisticated understanding understand of religious artwork on display in churches and how it related to the new religious orthodoxy. Many of the cases examined show images existing side-by-side with one damaged and one spared, an iconoclastic equivalence of the two men in the field as described in the Gospel (Matthew 24.40).

Like the pervious chapter, the influence of local lay authorities were directly tied to severity of destruction undertaken. On another level, this selective iconoclasm reinforces the spiritual supremacy of the Bible as the wellspring of spiritual authority, eclipsing even that of the monarch. In other instances, the generational continuity fostered an affection for certain church fittings, such as baptismal fonts which had been in use for centuries. The mutilation of these objects could be abided as long as they survived in some form for continued use. These results, and how they tie into the wider themes and research questions, will be assessed the Chapter VII discussion section. 


\section{Chapter VI: Reformation: Invention \& Redefinition}

This chapter will present a detailed analysis of new church fittings or refittings, commissioned after the 1534 Acts of Supremacy, which either survived undamaged or suffered some degree of destruction during the 126 years of religious transition, transformation and upheaval defined as the 'Reformation' in this study. The trends in new fittings evolve from the earliest sixteenth-century phases of the Reformation, with the usage of vernacular text and less ornate interiors, to the later seventeenth century phases that can be divided between the ostentatious High Church Anglicanism and the austerity of Puritanism.

\subsection{Baptismal Fonts}

The use of baptism in English liturgy, either High Church Anglican or Puritan, remained an important component of spiritual life throughout the explosive turbulence of civil strife during the mid-seventeenth century; however, the 'godly' did not equate the act with a means to salvation. Instead, it was viewed as an act of initiation into the community of faith which needed to be performed in public, without the elaborate vestments, as part of a worship service to prevent anything too ritualistic or 'popish' from transpiring (Neal, 1822, pp. xvii-xviii; Bremer \& Webster, 2006, pp. 320-21).

The high survival rate of medieval baptismal fonts, many of which were produced during the century preceding the Reformation, hindered the need for new fittings to be commissioned. Instead, it was far more prudent to modify and repurpose the existing fonts for continued sacramental use. As a result, only a scant few new fonts were produced during the timeframe of this study, as most of the existing fittings were relatively new and would be impractical to replace. We also see more font covers and canopies from this time, as woodwork was less durable and costly than stonework. 
A severe transition in decoration emerged on the few fonts created in the period, which provide an even clearer understanding of the new social priorities that drove and shaped the Reformation. Coats of arms and heraldic badges emerged as the primary decorative motif, replacing traditional medieval styles, such as the seven sacraments or figurative carvings; of the thirteen baptismal fonts across the four samples, five retains signs of heraldry.

As a result of the high survival rate of medieval baptismal fonts, the total number of new fittings produced following 1534 are relatively minimal with 3 for $R-N W(6 \%$ of total font count); 4 for $R-N E(6 \%) ; 5$ for $R-S(9 \%)$; and not a single new fitting found in Norwich. Font covers and canopies are more numerous, as the need and desire to update these less durable, and less expensive, fixtures was more practical. As previously discussed, medieval covers only survive in exception cases, such as Castle Acre $(R-N W)$ and St. Peter Mancroft $(U-N)$; however, early modern examples are more prevalent. The total number of new wooden font covers or canopies produced following 1534 is 3 for $R-N W$ (43\% of total cover count); 4 for $R-N E(66 \%)$; 6 for $R-S$ (75\%); and 6 for $U-N(86 \%)$.

The successive waves of iconoclastic activity driven by the legislation against images, as well as the increasing vehemence against 'idolatry' by puritanical reformers, shifted the content matter found on these fonts in a very modest and secular direction. While this transition does inform us of a transformation in social priorities through the implementation of a specific visual medium, it also suggests a safe and pragmatic approach taken by those who invested funds in having these fittings commissioned and did not want to see them damaged. The result is two decorative styles becoming prevalent on the octagonal bowls: coats of arms on heraldic badges and blank panels not featuring any carvings or patterns. These two approaches to font adornment reflect the Stuart divide in religion, between a Laudian sense of ritual and order and Puritan sense of austereness. 


\begin{tabular}{|l|r|r|r|}
\hline & $\mathbf{1 5 3 4 - 1 6 6 0}$ & $<\mathbf{1 6 6 0}$ & Rate \\
\hline R-NW & $(\boldsymbol{r})$ & $\boldsymbol{( f )}$ & $(\boldsymbol{r} / \boldsymbol{f})$ \\
\hline R-NE & 3 & 56 & $5.4 \%$ \\
\hline R-S & 4 & 73 & $5.5 \%$ \\
\hline U-N & 5 & 55 & $9.1 \%$ \\
\hline & 0 & 21 & $0.0 \%$ \\
\hline TOTAL & & & \\
\hline
\end{tabular}

Table 18: Baptismal Fonts: Produced 1534-1660

\begin{tabular}{|l|r|r|r|}
\hline & $\mathbf{1 5 3 4 - 1 6 6 0}$ & $<\mathbf{1 6 6 0}$ & Rate \\
\hline R-NW & $(\boldsymbol{r})$ & $(\boldsymbol{f})$ & $(\boldsymbol{r} / \boldsymbol{f})$ \\
\hline R-NE & 3 & 7 & $42.9 \%$ \\
\hline R-S & 4 & 6 & $66.7 \%$ \\
\hline U-N & 6 & 8 & $75.0 \%$ \\
\hline & 6 & 8 & $75.0 \%$ \\
\hline TOTAL & & & \\
\hline
\end{tabular}

Table 19: Baptismal Font Covers: Produced 1534-1660 


\section{R-NW Sample}

This section examines three new baptismal fonts constructed after the start of the Reformation found at Cockthorpe, King's Lynn and Gaywood. While the first two demonstrates the new trend of honoring religious authority in secular terms, the Gaywood font provides an example for High Church Anglican decoration that promoted Protestant thought with a Catholic-style.

\section{Case Study: Cockthorpe}

The parish of Cockthorpe, originally referenced as Thorpe before receiving its prefix to differentiate itself from other villages of the same name in Norfolk, has a medieval church dedicated to All Saints declared redundant in 1976. At the time of the Conquest, the bishop of Thetford held a portion of the town along with the manor of Langham and two freemen; the latter were seized by the aforementioned episcopacy in the late thirteenth century (Blomefield, 1808, p. 215). In 1411, the manor passed to Sir Oliver Calthorpe, whose lineage held the parish through the entirety of the Reformation and beyond. One James Calthorpe, whose 1503 last will and testament instructed burial in the chancel of All Saints, appears to have been a religious conservative as one of the refounders of a Carmelite friary at Blakeney, which ultimately served as his final resting place. At the start of the Reformation, the Calthorpe family expanded their reach through the marital acquisitions of additional holdings through Norfolk and Suffolk. In the wake of the Marian reign, All Saints underwent extensive renovations funded by an endowment left by James Calthorpe, grandson of the preceding James. In addition to a new lead roof in the south aisle, a new window was commissioned featuring the arms and effigies of the donor's family and Latin scripture (Blomefield, 1808, pp. 216-217). The remainder of the century saw the next lord of the manor, Christopher, admitted as a barrister at one of the Inns of Court in London before predeceasing his wife, resulting in her remarrying and depriving the family of several of their Suffolk holdings. The manor passed to another James, who distinguished himself as a knight and High Sheriff of Norfolk in 1616. The remainder of the Jacobean reign saw one James Calthorpe acquire the manor at Blakeney and even the advowson of the church, before selling the manor of Cockthorpe to his uncle, Henry Calthorpe of Ampton in Suffolk, who served as a law officer for Queen Henrietta Maria and her council. Henry was a complex figure within the broader context of the political 


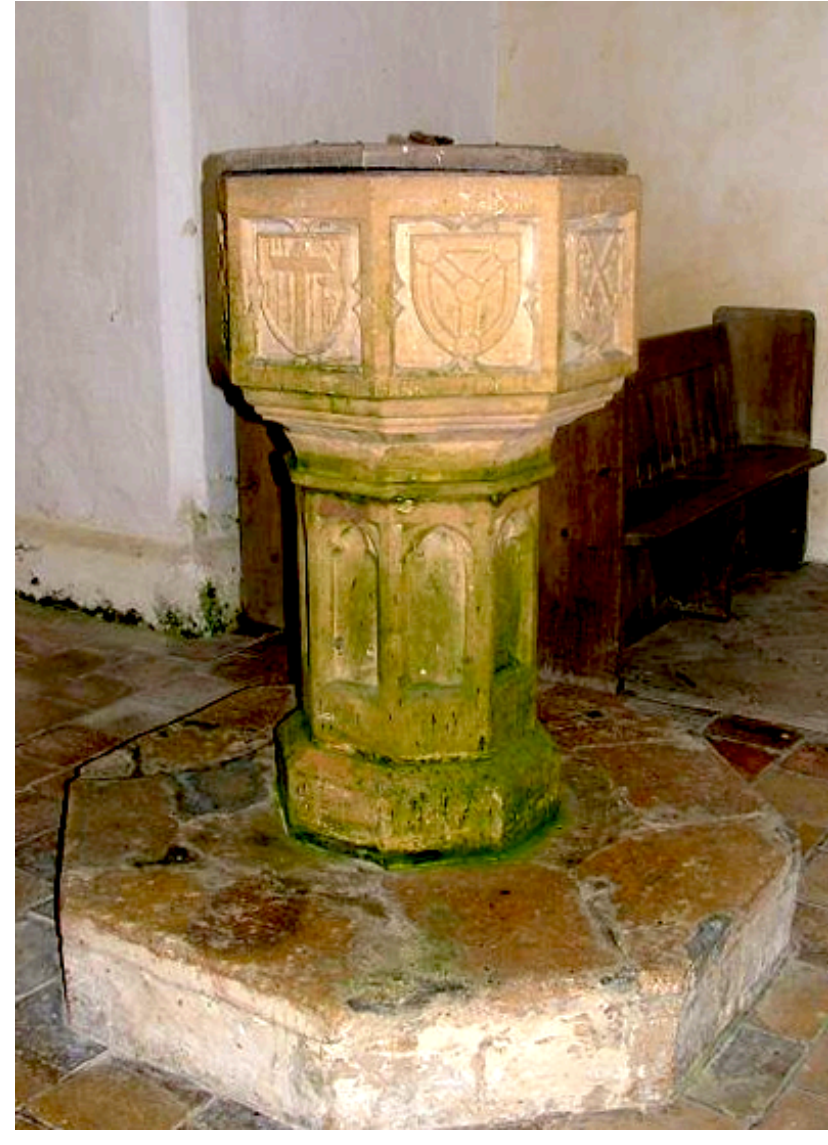

Plate 48: Baptismal Font: Cockthorpe turmoil as, despite his ties to the royal court, he defended one Benjamin Valentine, an MP from Cheshire, who was accused of physically restraining the Speaker of the House of Common as grievances against the king were read aloud (Tyler, 1893, p. 110). At his death in 1637 , Henry's manor passed to his son James, Sheriff of Suffolk, who came to be knighted by Lord Protector Cromwell in 1656 (Calthorpe, 1886, p. 261).

All Saints retains a seventeenthcentury stone font featuring religious heraldic carvings, the 'civic' successor to traditional medieval iconography (Plate 47; Pevsner \& Wilson, 1999, p. 437). With seven visible shields, the content selected to decorate this fitting complement several of the surviving subjects addressed in Chapter IV. The eastern facing panel is two crossed skeleton keys emblazoned on a shield, a common representation of St. Peter as drawn from a biblical exchange between Christ and his chief disciple (Matthew 16.19). This coat of arms was common in medieval ecclesiastical heraldry, at was used as the official emblem of the pontiff, along with the papal tiara positioned above the keys. The use of this symbol, which also served at the escutcheon for the bishop of Gloucester, was as 'popish' as an icon could be without crossing the line and could rely on the argument that the image was used in honor of a key figure from scripture. This 'biblical' use of heraldry, rather than a subversive attempt to infuse Catholic iconography, is supported by the panel to its immediate right featuring two swords crossed upon a shield; this image is a common representation for the martyrdom of St. Paul, as opposed to the single sword commonly seen in its Catholic incarnation (Lanzi \& Lanzi, 2004, pp. 6061). This apostolic theme continues with another emblem featuring three scalloped 
seashells, the crest for St. James the Greater (O'Neill, 1983, p. 77), and yet another featuring a saltire, commonly associated with the martyrdom of St. Andrew.

The aforementioned saltire is also associated with Scotland, which at the time of this font's construction, had been united with England following the ascension of the Stuart dynasty. It is possible that this coat of arms was added with these secular intentions in mind, as two panels down feature St George's Cross, which had emerged as the royal standard of England, as well as the only banner associated with a saint to not be abolished in 1552 (Perrin, 2012, pp. 40-41). It is of interest to note that panel between the St. Andrew/Scotland and St. George/England bowl faces feature a blank shield, possibly for the future addition of other coats of arms. It is difficult to surmise what was intended for carving in this space; however, the possibility exists that this shield was decorated with paint to allow periodic changes to be made, as will be seen later with a Jacobean survival in New Buckenham.

This innovative implementation of new iconography, bolstered by its biblical subject matter and quasi-secular style, was joined by two forms of religious heraldry discussed previously as undamaged medieval survivals: the Arma Christi and the Holy Trinity. These two images, along with the four apostolic and patron saints, are all drawn from the New Testament, with the exception of St. George who often fared very well in terms of survival in England. The method of integrating iconography as heraldry illuminates another shift in social values resulting from the Reformation, the importance of religious accomplishments in temporal terms, as highlighted by the emphasis on martyrdom and lay authority.

\section{Case Study: King's Lynn St. Nicholas}

The bishop of Norwich, William de Turbeville, who had previously served as prior of the Benedictine monastery at Norwich Cathedral, founded St. Nicholas Chapel in King's Lynn in the mid twelfth-century. This connection prompted him to provide the new church, along with all of its profits, to the priory; although, at its consecration it was prohibited from performing marriages or baptism. Instead, the chapel and its parishioners relied on the neighboring St. Margaret's church and priory, which later became solely a parish church, following the Dissolution (Blomefield, 1808, p. 494). 


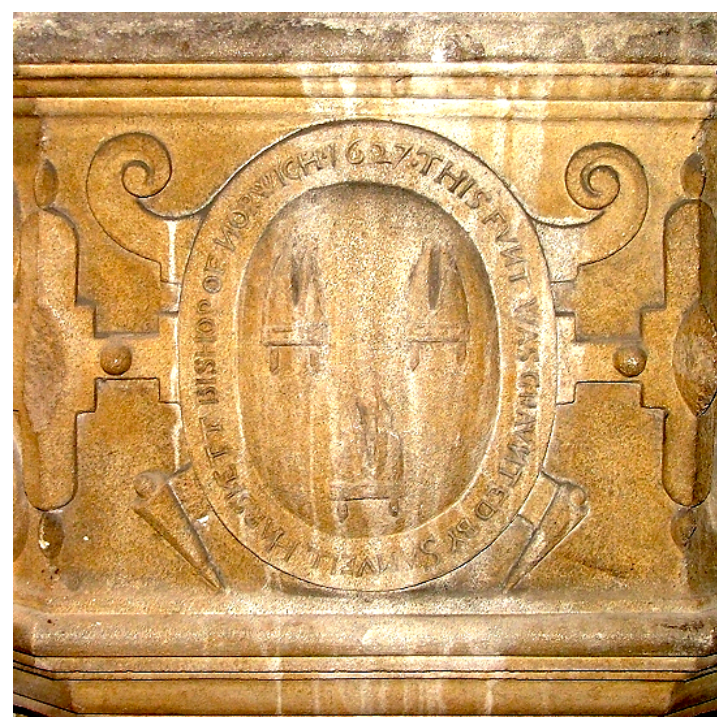

Plate 49: Baptismal Font: King’s Lynn

St Nicholas

An ambitious chaplain attempted to circumvent the ecclesiastical politics preventing the authorization to perform baptisms and appealed directly to Rome, which responded by granting a license; however, the intervention of the bishop and prior led to the papal bull being recalled. As late as 1609 , the matter was again brought up in a consistory court in Norwich who again ruled against, as it was argued that the curate from St. Margaret was sufficient (Blomefield, 1808, pp. 503-504). In 1627 , the situation was finally resolved, as Samuel Harsnett, bishop of Norwich and future archbishop of York, provided the church with its first baptismal font in a location prepared at the parishioner's expense the previous year, with painting and gilding added in 1635 (Beloe, 1926, pp. 16-17, $22-$ 23). It is of interest to note that Harsnett gave a sermon while in King's Lynn presenting the font, that extolled the town's public lecturers (Reynolds, 2005, p. 113). These two acts may have been an attempt to endear himself with the diocese, as he had previously been charged before Parliament with high-handedness by the citizens of Norwich and having a complaint lodged again him to King Charles I for the persecution of Puritans in Great Yarmouth.

The font, which sits upon a three-step platform, appears to be a rare case of a new basin affixed to an earlier stem and base (Plate 48). The designers of the church envisioned a day when necessity would lead to the installation of a font, as the pedestal, and even stem, is Perpendicular Gothic in style complete with circled quatrefoil carved into the risers on each step. The bowl provided by the episcopacy is a testament to seventeenthcentury sensibilities, with its use of heraldry, text and decorative strapwork. Seven of the eight panels feature basic interlaced scrollwork, no doubt an attempt to make the fitting look more regal without delving into anything that could be perceived as controversial. The eastern panel features a carving of the heraldic emblem for the 
diocese of Norwich, three miters, set within a vertical oval as opposed to a shield. The symbol is outlined with the text:

THIS FVNT WAS GRAVNTED BY SAMVEL HARSNETT BISHOP OF NORWICH 1627

This fitting, offered by a senior churchman with Laudian sensibilities and a proclivity for tolerance when it suited his ambition, proved to not offend the Puritan position on images. By mid-1643, the city was besieged and surrendered to Parliamentarian forces after openly declaring for King Charles earlier in the year. Governance of Lynn was entrusted to Oliver Cromwell's brother-in-law, Valentine Walton, who did not see fit to unleash the iconoclastic impulses that which were often unleashed in the wake of Roundhead occupation.

\section{Case Study: Gaywood}

The parish of Gaywood is home to a medieval church, dedicated to St. Faith of Conques, which features a rare baptismal font designed in a High Church Anglican style being promulgated during the during the archiepiscopacy of William Laud (Plate 49). Four of the eight panels found on the bowl feature inscriptions, with one written in the vernacular, the rest in Latin. The inclusion of text, a common result of early phases of religious reform, shifted back to a traditional method of creating a linguistic barrier, which had always existed in the Catholic mass, and served as an alternative to maintain the 'mysteries of faith' in an increasingly literate culture. It is interesting to note that the Armenian-influenced font features three truncated passages from the New Testament in Latin, while the one Toraic reference is provided in English with a reference. The vernacular panel reads:

\section{AM THY GOD AND THE GOD OF THY SEEDE GEN}

This passage, which is a reference the original covenant between God and man (Genesis 17.7), ties the sacrament of baptism as the gateway to the new divine relationship as mediated by Jesus. The second panels reads: 


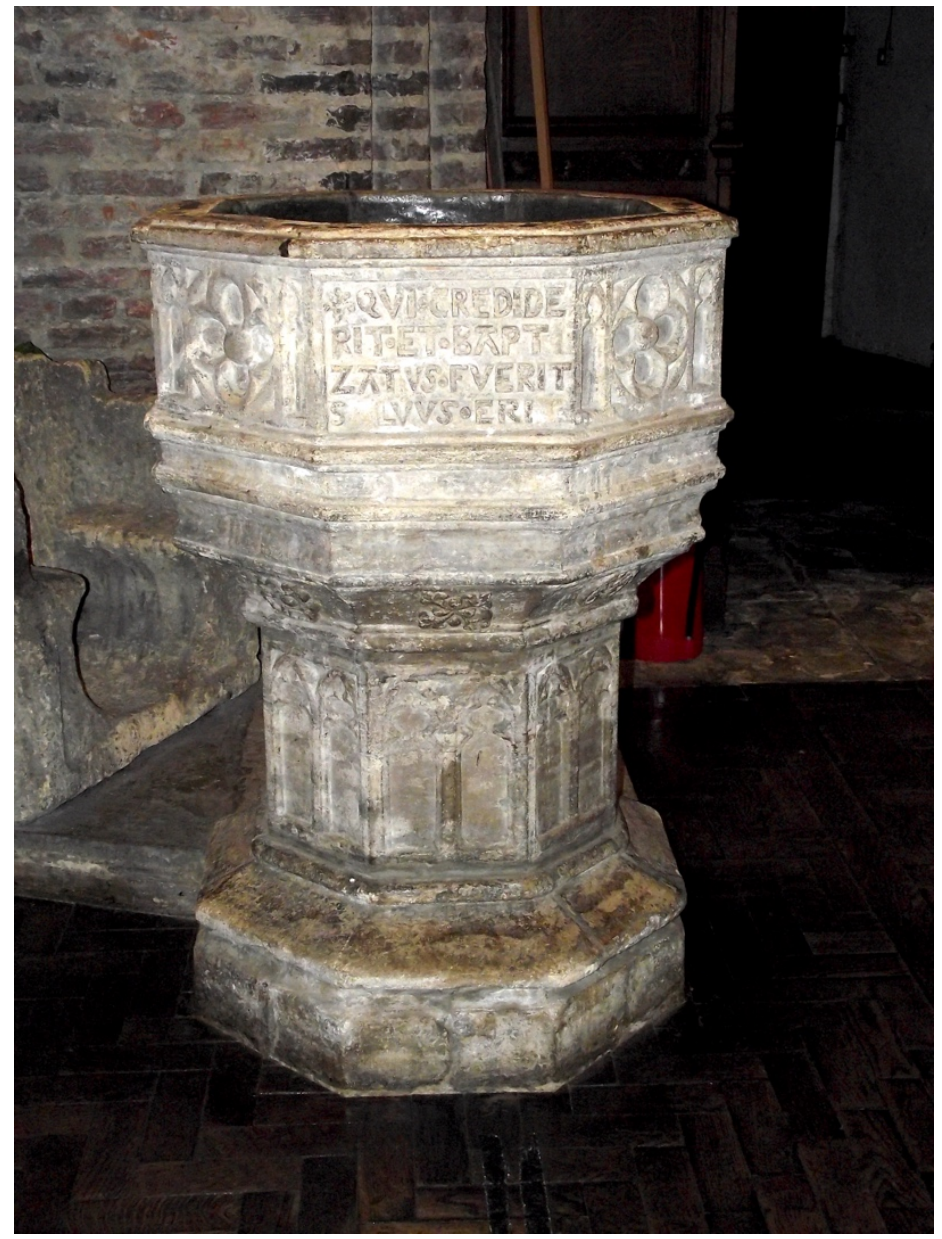

Plate 50: Baptismal Font: Gaywood
QVI CREDIDERIT ET

BAPTIZATVS FVERIT

SALVVS ERIT

This inscription is a Gospel

reference that creates an absolute connection between salvation and baptism (Mark 16.16), thus heightening the importance of the Anglican liturgy that empowered the rite. As we have seen, baptism remained a vibrant, and reasonably uncontroversial, expression of faith in the English Church. Those who sought to elevate the 'High Church' position and inject ritual practices,

reminiscent of Catholicism, would need a liturgical expression like baptism as the cornerstone of their program. The third inscription is:

\section{VOCE PATERNATUS CORPOREFLAMEN AVE MAT 3}

This reference to scripture furthers the sacramental importance of baptism, as a divine event rather than merely a symbolic requisite for becoming one of the Christian faithful. The passage is a condensed account of the baptism of Christ, which declares the presence of the Father, Son and Holy Spirit at the time of baptism through the voice, bodily presence and dove, respectively (Matthew 3.16-17). Again, the language chosen for association with this ritual evokes a Catholic sense of liturgy, which is enhanced by a Latin presentation. The final carved inscription reads: 
This reference comes from St. Paul's letter to the Galatians regarding baptism, in which the new member of the faithful is described as being baptized "into Christ" as opposed to "in the name of Christ". This references ties into the preceding theme of baptism being a divine initiation into the faith, as opposed to something as pedestrian as a swearing of allegiance or fealty to the Church. Furthermore, the reference implies a complete, and intimate, union forged with Christ as you are "clothed in Him", no doubt another subtle reference to High Church proclivity for ceremonial vestments (Ellicott, 1987, p. 448; Galatians 3.27).

The remaining four panels all feature a single quatrefoil and the overall design is very similar to another Laudian font on display at All Saints in Tilney. It can be assumed that this particular font was constructed at the same time, as it is identical in aesthetic and features alternative biblical references to baptism. The Gaywood fixture offers a glimpse at the intense religious divide growing in the early seventeenth-century, and provides an alternative example to the new standards of religious iconography seen at Cockthorpe, or the secular glorification of clerical sovereignty seen in Lynn. The only common thread is that each of these fonts did possess some degree of stonework; as opposed to several cases of bare facets we will observe in the following groups.

\section{R-NE Sample}

This section will examine a new font provided for the parish at Rackheath by a prominent family. Additional case studies will not be provided, as the remainder of the sample features new fonts devoid of any decoration. Fittings like these, All Saints in Horstead and St. Michael in Oxnead, are in stark contrast to the deliberate use of "new iconography" seen in the examples in the previous group. 


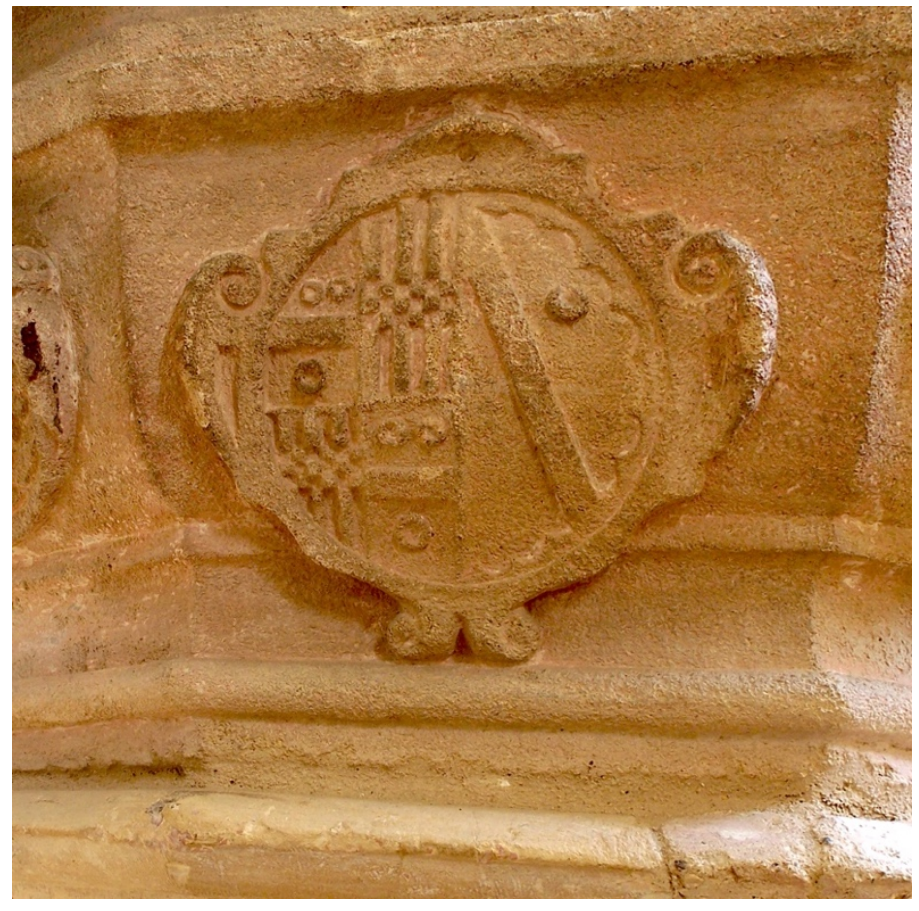

Plate 51: Baptismal Font: Rackheath

\section{Case Study: Rackheath}

All Saints church in Rackheath, known as Rackheath Magna in the early modern period, came under the influence of a powerful Norfolk family when the manor was sold from William Helme to Thomas Pettus in 1590, who was serving as alderman and mayor of Norwich in that year (Blomefield, 1809, pp. 446-451). By the middle of the seventeenth-century, the Pettus family continued their

ascendancy by maintaining strong ties with the Stuart monarchy culminating in Sir Thomas Pettus, great-grandson of the aforementioned Thomas, following Charles I on his campaigns in Scotland and Northumberland from 1639-40. For his "laudable zeal and loyalty", he and his issue were created as baronets of Rackheath (Collins, 1741, pp. 270-271).

On the eve of his ascension, Thomas furnished All Saints with a new stone font adorned with seven cherub faces on the seven facets of the bowl and his family's coat of arms (Plate 50). This lurid inclusion of secular heraldry on such an important piece of church furnishing is bolstered by the inscription $B, P$ ornavit 1639 to avoid any potential confusion of which member of the esteemed family commissioned the font for the parish.

The Rackheath font offers yet another change in acceptable decorative motifs, with the inclusion of purely secular imagery, a far cry from the reverence of the inscriptions found at Gaywood. Such an inclusion is indicative of wider cultural upheaval transpiring in England during the sixteenth and seventeenth centuries, with the 
transformation of religious authority, broadening secular powers and their complex causal relationship with the context of the Reformation.

\section{R-S Sample}

This section will examine two fonts found at the parish churches at New Buckenham and Ashwellthorpe. While the former is actually a medieval survival that was recut and painted, thus making it an innovation, the latter demonstrates the collision of interests between a local family of prominence and a Parliamentarian representative enforcing official religious legislation.

\section{Case Study: New Buckenham}

The burgh of New Buckenham emerged from the parish of Buckenham in the twelfth century as a result of the acquisition of property to the southeast by William D'Albini from the bishop of Norwich; and his subsequent development of the neighboring town and construction of a new castle to succeed the previous one. With the redundant castle granted to an order of Augustinian canons for the establishment of a new priory, D'Albini had a new chapel dedicated to St. Mary built close to his new castle to serve its parishioners; however, the ensuing century saw enough growth in the town's population for the construction of a new parish church dedicated to St. Martin, with St. Mary Chapel becoming a private sanctuary for the castle. The Dissolution saw the expansion of property held by the local gentry, with the dissolved priory at Old Buckenham Castle being granted to Sir Thomas Knevett (Taylor, 1821, p. 29). The new castle, and its chapel, survived unmolested during the remainder of the Tudor reign, until the castle was defortified in 1649 by Parliamentary order following the defeat of Charles I.

Rather than deface or replace their font, the entire exterior was recut with a simple design lacking anything resembling religious iconography (Plate 51). Due to this complete transformation in aesthetic, this fitting qualifies to be discussed in this chapter even though its original incarnation was medieval in origin. Furthermore, it is impossible to know what images this work supersede, or if they had suffered any previous damage which could have occurred during the Edwardian phase of the Reformation. The eight sides of the basin now feature alternating geometric shapes, 
quatrefoil and strapwork set upon a high single-step pedestal, which retains what appear to be original carvings, with more quatrefoils and blank shields. The panels of most interest on the fixture feature black and red painted text featuring: the date Feb 1 1619 across the four corners of the panel with a central vertically elongated quatrefoil; and the Latin renditions of Thomas Colma, or Thomas Colman, and Xpofer Sudburi, or Christopher Sudbury, with the words Church=wardens inside a central ellipse. The stem features alternating lions and wildmen, however, the crispness of the carvings suggest they were carved or recarved in more recent times; perhaps a consequence of Victorian restorative work.

The use of decoration to honor two lay officials of the parish is unprecedented in Norfolk, yet appropriate in regards to the firm sense of local autonomy reflected by the unique arrangement regarding the selection of a parish minister. The church of St. Martin was a representative institution of its parishioners, as the minister was selected by a plurality of votes. As the residents of the parish provided the minister's salary, the churchwardens lodged the results of such an election in the town for the lifetime appointment upon the procurement of a license from the bishop of Norwich (Blomefield, 1805, p. 397).

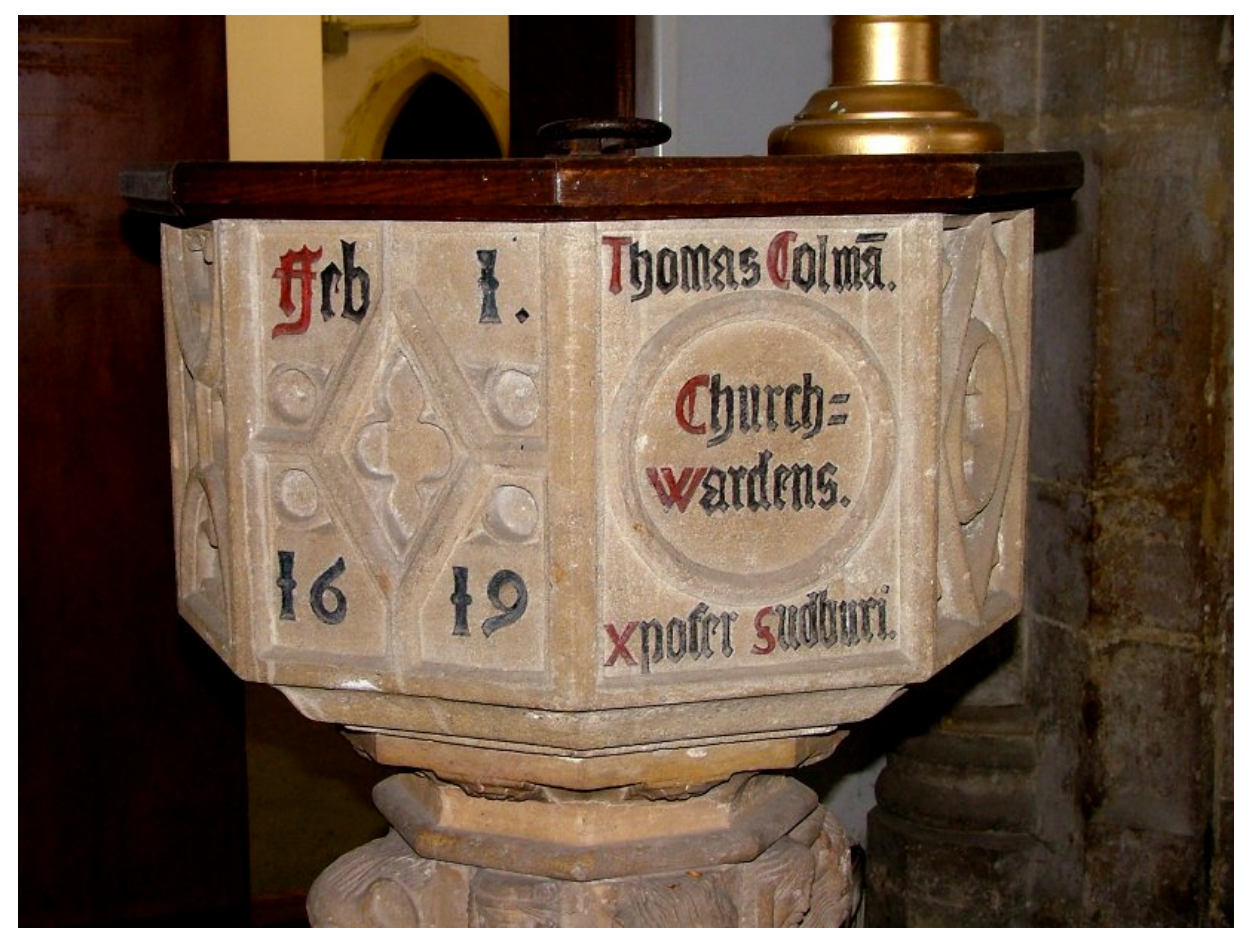

Plate 52: Baptismal Font: New Buckenham 


\section{Case Study: Ashwellthorpe}

A parish church dedicated to All Saints and a chantry chapel dedicated to St. Mary served Ashwellthorpe, originally two small settlements; the latter was seized during the Edwardian suppression of the chantries and purchased by Sir Thomas Knyvett, de jure fourth Baron Berners, in 1598. All Saints suffered extensive damage during a visitation in 1644 by a Captain Clement Gilley, who was commissioned by the same Parliamentarian order that authorized the Suffolk visitations under William Dowsing (Spraggon, 2003, p. 122). In 1644, Thomas Knyvett, de jure fifth Baron Berners, was arrested by a Parliamentarian force coming from Yarmouth, under the command of Oliver Cromwell, and relocated to Cambridge. During this time, Gilley arrived in Ashwellthorpe and was appalled by the extensive violations he witnessed. In a correspondence between Knyvett and his wife, Katherine Burgh, his primary concern appears the family's coat of arms in the window, lest it be indiscriminately destroyed along with any other religious iconography (Spraggon, 2003, p. 323). It is possible that the existing baptismal font was destroyed in the wake of this visitation, as within sixteen years the church required a replacement supplied by the Knyvett family in 1660 (Plate 52). This new fitting, presented two years after Thomas' death, features the family's carved heraldic shields emblazoned with vibrant paintwork, no doubt a more recent restoration of the original work. The use of secular decoration, honoring the family responsible for financing the fitting, is a common motif in post-medieval innovation and is the hallmark of funerary monuments (Finch, 2000).

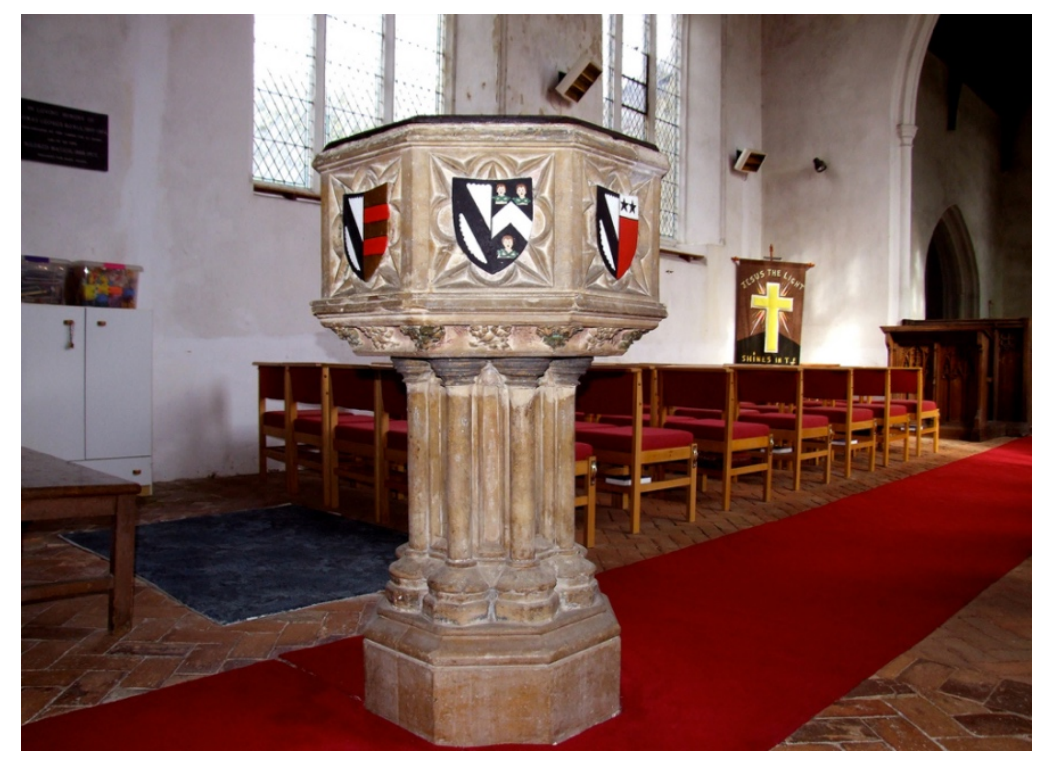

Plate 53: Baptismal Font: Ashwellthorpe 


\section{U-N Sample}

The $U-N$ sample does not possess a single baptismal font produced between 1534 and 1660, despite having seven Elizabethan/Jacobean covers above medieval stone survivals. These covers have survived at a higher rate than their rural counterparts, which may be a testament to a combination of prosperity and liberal tendencies of the city.

\section{Case Study: Norwich - St. Gregory Pottergate}

The parish church of St. Gregory Pottergate was crucial to the development of the western side of Norwich, as its rapid growth resulted in its subdivision into four additional parishes (Ayer, 2005, p. 4). The Valoines family possessed the advowson until it passed to John Fitz-Bernard; his descendent, Walter, relinquished his position and offered it the Benedictine monastery at Norwich Cathedral. In 1289, after a brief stint as a strangers' hall, the vicarage was given to the retired monks of Norwich Cathedral Priory, who collected all of the tithes and paid a priest to serve the church. The subsequent centuries saw the priory enlarge the churchyard and an array of repairs

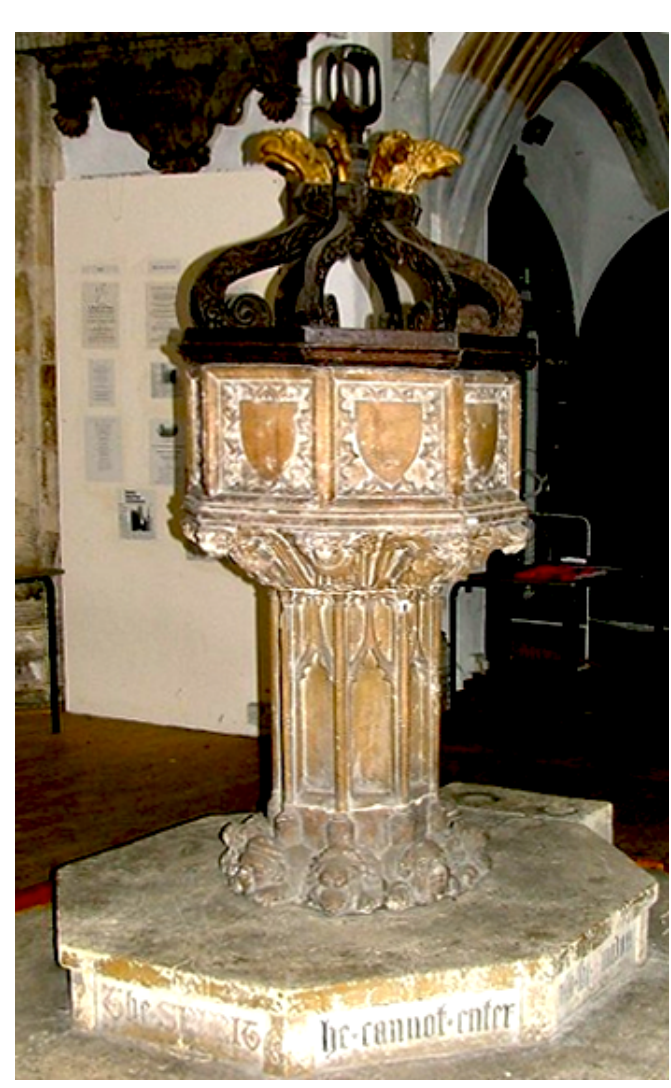

Plate 54: Baptismal Font: Norwich St Gregory Pottergate were conducted on the roof, chancel and priest's chambers. Despite Henry VIII's move against the monasteries, the conversion of the monastery into a secular cathedral allowed St. Gregory to remain in the hands of the dean and chapter. A side chapel, dedicated to the Assumption of the Blessed Virgin featuring her image upon an altar with a candle always illuminated, was utilized to celebrate the Holy Name of Jesus; a common medieval ritual promoted in early Tudor England until it succumbed to the Dissolution (Blomefield, 1806, pp. 272-273). The remainder of the sixteenth century saw images removed, church plate sold, the addition of a towering lead spire and even a failed attempted to unify the parish with St. Laurence. 
A beautification campaign, financed primarily through elective contributions in 1626, placed St. Gregory at the center of religious tension set within the broader context of the growing struggle between High Church Anglicans and Calvinists. Using scripture as a framework (Psalms 26.8), the work was justified as "so pious a work, as the beautifying God's house or habitation, the place where his honour dwelleth" (Blomefield, 1806, pp. 272-273). This move back towards a more ritualistic expression of faith anticipated the policies promoted the following decade during the archiepiscopacy of Laud, as special emphasis was placed on enriching the altar and installing rails around the medieval baptismal font (Plate 53). The latter was repaired in the preceding years at the expense of several prominent parishioners, including two judges, a minister and a sheriff. This work included an ornate octagonal base constructed by one Jeames Avys, a known Catholic, which appears to have included the vernacular inscription of Jesus' declaration regarding baptism: Except a man be born of water and of the Spirit, the cannot enter into the kingdom of God (John 3.5). In addition to these additions being authorized by the churchwardens, John Freeman and John Weever, the existing font cover, featuring ornate representations of Christ, the Apostles and Noah's family, was allowed to remain in opposition to Article 23 of the 1559 Injunctions, which outlawed idolatrous depictions (Reynolds, 2005, p. 148). It should be noted that all representations described are extrapolated directly from the Bible, of which an authorized translation had been in circulation for over a decade. These additions angered the more radical reformers, who attempted to petition Bishop Samuel Harsnett to intervene and enforce the previous Injunctions to the letter of the law. Despite receiving a formal order to remove the iconography, the churchwardens largely ignored the requests as the complaints as Harsnett failed to include his official seal on the document, no doubt an attempt to distance himself from the ensuing controversy. That being said, it is possible the churchwardens made an effort to placate the protests through the removal of a fitting featuring iconography, while hoping to keep the additions with liturgical significance (Spraggon, 2003, pp. 16-17).

The aforementioned cover did not last long, as a more modest fitting was installed within a few years of the font repair; perhaps as part of the broader beautification campaign. A wooden cover with eight low volutes, featuring carved strap work, has 
eight gilded bird necks and heads, which have been identified as eagles (Annual Congress at Great Yarmouth and Norwich, 1880, p. 343). Medieval Christian art integrated this creature as a result of the belief that an eagle could gaze directly into the sun, a metaphor for the clergy's ability to engage sacred revelation (Taylor, 2005, p. 35). Furthermore, this symbol could represent an evangelizing mindset of the Gospel, specifically as portrayed by John, being whisked across the world (Delderfield, 1966, pp. 71-72). Both interpretations have post-Reformation applications in England, as the laity could now face the divine revelation derived from reading scripture and be burdened by a renewed desire to proselytize to the world, beginning with their own country. The use of an eagle, usually reserved as an alternative to the pelican, was often seen on lecterns and was rarely utilized in the centuries following the Reformation (Cooper, 2013, pp. 204-206). It is remarkable that a complex iconographic depiction, like the eagle with its renewed relevancy, was chosen to supersede its ornate, yet Biblical, predecessor.

\section{Case Study: Norwich - St. Stephen}

In addition to this wooden cover at St. Gregory, St. Stephen retains an iron font cover dating from 1616. Over the next two years, the fitting was gilded and adorned with a pelican (Bond, 1908, p. 285). Despite not possessing any scriptural basis, the pelican is an abstract symbol that evokes the sacrificial nature of Christ (Ross, 1997, p. 49). The idolatrous, yet indirectly biblical, nature of this motif suggests that the criteria for acceptable imagery transformed at Norwich in even conservative circles.

Norwich retains several seventeenth-century furnishings that are indicative of the Puritan opposition to iconography and penchant for functionality. St. Peter Hungate holds a simple wooden cover, dated 1605, sitting atop its medieval font (Plate 54; Pevsner \& Wilson, 1997, p. 247). The furnishing is octagonal, to match the stone basin, with an openwork steeple. The modest design of the cover is a perfect contrast to the impressive, but necessary, medieval font. This design became the model for a series of covers produced three decades later. 


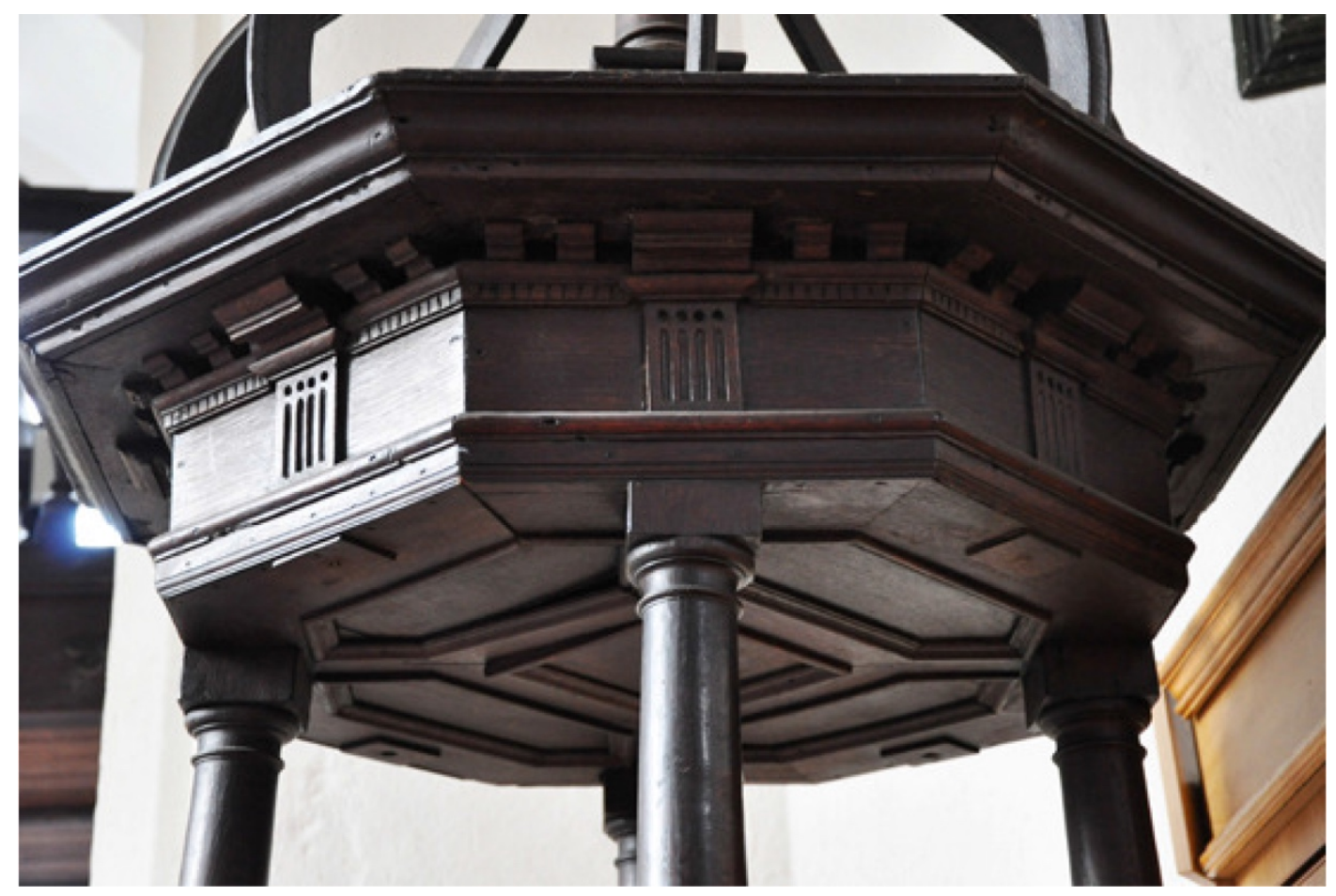

Plate 55: Baptismal Font Cover: Norwich St Stephen

\section{Case Study: Norwich - St. Andrew}

The medieval parish church of St. Andrew, which was the second largest in the city behind St. Peter Mancroft, emerged as a stalwart bastion of Protestant ideology through the Reformation. Following the acquisition of a once-Saxon rectory by one John le Brun, and subsequent transference to the College of St. Mary in the Field, construction of a new building commenced in the late fifteenth century and was completed in 1506 (Anon., 1781, pp. 371-372). The decision to place a prominent, and large, church along the main route between the market and Cathedral ensured it would play a major role in the upcoming upheaval that the church would face within a few decades. Following the Edwardian dissolutions, the church passed from the college to the Crown, who granted the advowson and vicarage to be held by two gentry families in the city. In 1559, the church was purchased by trustees and established as donative institution with power in the hands of the parishioners. Rather than using this autonomy to resist the liberal excesses of the Reformation, they embraced the break with the traditional faith and emerged one of the most progressive parishes in the city. 


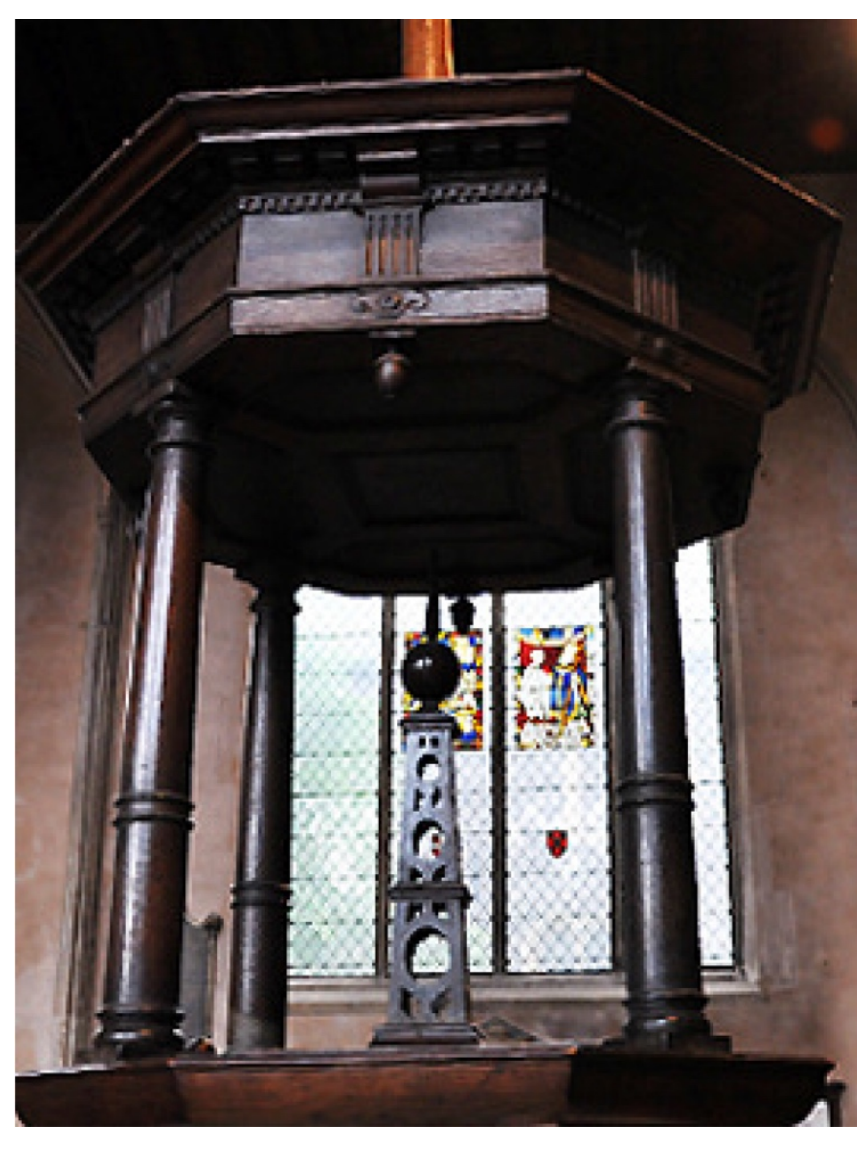

Plate 56: Baptismal Font Cover: Norwich St

Andrew
St. Andrew retains a wooden cover and canopy dated to 1637 , featuring four columns, an openwork obelisk in the center, and an octagonal canopy (Plate 55; Pevsner \& Wilson, 1997, p. 231). The perimeter of the canopy has simple accent carvings and eight strippeddown heraldic designs. It is important to note that this postReformation addition is not adorned with any figurative carvings, images, or even ornate decoration. The functional simplicity of the fitting is consistent with the creative impulses of Puritanism, which had their iconophobic tendencies galvanized by the reintroduction of ritualistic

furnishings promoted by Laud. It should be no surprise that a cover of this nature was featured at St. Andrew, which emerged as a stalwart bastion of 'godly' Protestantism following the Reformation. It is interesting to note that this is one of the only cases in Norwich where a cover predates the stone font, which is an 1878 replacement. The Victorians most likely created an elaborate new cover in conjunction with the new font, as the cover was found in excellent condition disassembled in the belfry before being restored (Groves, 2010, p. 21).

The style of the St. Andrew font cover emerged during the personal rule of Charles I and archiepiscopacy of Laud, which sought to forge a uniform, and more ritualistic, worship across the country. In response to these changes, Puritans promoted their own spartan interpretation of religious expression. These notions were popular with many citizens of Norwich, who often relied on their status as a county corporate to advocate their own local positions in national affairs. The parish church of St. George 
Tombland, located between the Cathedral and St. Andrew, has a nearly identical cover standing above its thirteenth century stone font. Despite possessing similar decorative carvings, this furnishing has its simple gold-trim paintwork restored to its original glory, an ornate touch to modest design. Today, the top of the canopy includes a carved effigy of St. George on horseback, another Victorian addition.

St. Michael-at-Plea also has a font cover in this style, with the addition of a dove carved upon the central obelisk. The undeniable stylistic connection between the three aforementioned covers implies that they were all constructed as part of a series (Ladick, 2011, pp. 42-43). It is interesting to note the contrast between the iconography utilized by Catholics, and later High Church Anglicans, and the minimalist approach of the Puritans. While the reintroduction of elaborate church furnishings and ornaments recalled medieval Catholicism, Puritanical furnishings were less ostentatious and more utilitarian. The simple carved designs on the covers were not visually stimulating, which was consistent with a sense of unyielding discipline, and a literate-centric faith. Furthermore, the obelisk design was theologically neutral. The carved dove, often used as a symbolic representation of peace or the soul, on the St. Michael-at-Plea cover, is the closest thing to iconography. While no extensive study on Puritan visual imagery in England has been conducted, it is commonly assumed that any incorporation of symbols was devoid of sacrality (Ludwig, 1966, p. 43).

\subsection{Screens}

An analysis of the extended English Reformation reveals that the role of the screen in a parish church was transmogrified from a special division of sacrality to a practical demarcation still required for the liturgical needs established in the Book of Common Prayer. New churches built during this period were invariably outfitted with a new chancel screen; albeit, without an accompanying rood or loft. Norfolk does provide many instances of this, as their extensive building and renovations in the preceding centuries left them with a surplus of churches needed to service its populace.

This study extends its definition of post-Reformation screens to include both fittings created between 1534 and 1660, but also the implementation of new artwork on existing ones. While a selection of screens was repainted in the nineteenth century, the 
methods employed by the Victorian restorers were distinct enough to distinguish them from Reformation-era additions clearly.

\begin{tabular}{|l|r|r|r|r|r|}
\hline & $\mathbf{1 5 3 4 - 1 6 6 0}$ & $\mathbf{1 5 3 4 - 1 6 6 0}$ & TOTAL & $<\mathbf{1 6 6 0}$ & Rate \\
\hline R-NW & Produced & Repainted & $\boldsymbol{( r )}$ & $\boldsymbol{( f )}$ & $(\boldsymbol{r} / \boldsymbol{f})$ \\
\hline R-NE & 2 & 3 & 5 & 32 & $5.56 \%$ \\
\hline R-S & 3 & 0 & 3 & 36 & $2.86 \%$ \\
\hline U-N & 0 & 7 & 7 & 32 & $9.21 \%$ \\
\hline & 0 & 0 & 0 & 6 & $0.00 \%$ \\
\hline TOTAL & $\mathbf{5}$ & & & & \\
\hline
\end{tabular}

Table 20: Screens: Produced/Repainted 1534-1660 


\section{R-NW Sample}

This section will examine two rood screens located in the parishes of Binham and St. Margaret, now known as King's Lynn Minster. The Binham screen is actually a medieval survival; however, the extensive paintwork added during the Reformation qualifies it as innovation for the purposes of this study. A late sixteenth-century screen built for St. Margaret at King's Lynn demonstrates a new plain sensibility in design, with a focus on paying homage to secular authorities.

\section{Case Study: Binham}

The chancel screen on display at the Church of Saint Mary and the Holy Cross, formerly Binham Priory, illustrates the use of decoration that concurrently acts as both iconoclasm and innovation. As described in the previous chapter, the parish of Binham was served by a church dedicated to Holy Cross, which operated out of the nave of Binham Priory. The church altar, sedilia and piscina were positioned in the seventh bay, just short of the pulpitum, which marked the beginning of the choir. This cohabitation came to end as the priory was targeted for suppression following the 1535 legislation passed against the smaller religious houses across England. In spite of producing three conflicting confessions from various monks, the priory survived this initial wave of closures as no details were provided from the visitation reports provided (Page \& Doubleday, 1906, pp. 343-346). By March 1538, Sir Richard Rich investigated the situation further and discovered that although Binham was a dependent house of St Albans Abbey, they had been levying fines and granting leases under their own seal. This violation was reported to Thomas Cromwell, resulting in the official suppression in May of the following year with the final prior being granted a pension. That September, the priory, manor and advowson of Binham came into the possession of Sir Thomas Paston. He promptly commissioned the construction of the east wall and widow at the pulpitum, so as to leave the parish church relatively undisturbed; the remainder of the structure was used as a material quarry for new structures, including large homes in Wells and Appleton.

The rood screen, which served the parochial needs of the church, may have been provided to the parish at the expense of the Benedictine landlords (Plate 56). Traces of a mutilated donor inscription along the top rail of the dado reads 'orate pro bono 
fratru', which is a request for prayers for a monk's soul, suggests that the monastic order played an active role in the parish and in facilitated the parochial needs of their tenants (Mitchell, 2000). In its original form, a dado featuring six bays, each divided into four panels, provided the foundation for the screen. A monochrome painting by John Thirtle (1777-1839) produced in the early nineteenth century features the screen in situ and still retaining its rood beam and modest tracery, in spite of the loft being removed during some stage of the Reformation. With approximately twenty-four images of saints facing the nave, it does not come as a surprise that these depictions could no longer be abided by the new lords, who were endowed with manors as a direct result of monastic suppression.

During the reigns of Edward or Elizabeth, these panels were all whitewashed and decorated with large swaths of New Testament text derived from the authorized 1539 vernacular translation commissioned by Cranmer and compiled by Myles Coverdale (Whiting, 2010, p. 18). The use of these passages from the Great Bible, in contrast to the more common Lord's Prayer or Commandments, suggests a very specific message intended for the congregation. The first bay, comprised of four panels, features a passage from the First Epistle of Peter 1.13 through 16. These verses encourage the faithful to openly declare their faith in Christ and abandon past ignorance in favor of a newfound holiness. This theme of reconciling a past of erred belief, which fueled religious tyranny, is continued in the second bay. Forgiveness and love are the themes found in Colossians 3.13b through 15, both of which were intended to result in a perfect unity; something which the fledgling Church of England needed in abundance.

The third bay presents a passage that encourages all Christians to be accountable for understanding their new religious tradition and be prepared to articulate it in the face of slander (1 Peter $3.15 \mathrm{~b}$ to 17 ). This notion of a greater comprehension of one's faith is in sharp contrast the medieval notions of sacrality, which reserved such matters for those who received the sacrament of Holy Orders. The passage continues to chastise those who discourage such behavior, while reminding that any resulting persecution is preferable to disobeying the will of God. The final completed passage found in the fourth bay and continues in the fifth bay, or the first and second on the south side of the dado, is taken from the First Epistle to Timothy. In this passage, the monastic heritage 
of the church helps lay the foundation for the austere ethic to emerge in the following century within Puritanical thought. An appreciation for the bare essentials is lauded as crucial to avoid the ruinous destructions which can result from succumbing to the temptation of wealth (1 Timothy $6.6-9,10-12)$. This holiness helps bridge the gaps between destructive excesses of Protestantism and Catholicism, under Edward and Mary respectively, and the new moderate approach to faith being ushered under the Elizabethan settlement.

The use of specific passages of scripture provides a nuanced glimpse into the religious imperative of the reformers who commissioned their creation. Far from merely adhering to royal injunctions regarding the destruction of images, this church chose to promote new moral instruction derived directly from the Bible; an appropriate contrast with the monastic order, which once thrived in the space just beyond this screen. Today, the complex social transformation ushered in by the Reformation is on display in a striking fashion, as traces of the original painted figures have emerged through the whitewash. The first bay features: St. Michael the Archangel and St Katherine of Alexandria, towards the top left there are the spokes of a wheel on which she was broken, an unknown female figure wielding a crosier and two jars, and another unknown figure holding a gold Patriarchal Cross; his clothes are black and gold.

The second bay features two identifiable images; two more are still covered. While the first panel can clearly be identified as King Henry VI, the second panel features a female saint, which has often been erroneously identified as St. Mary of Egypt (James, 1930, pp. 171-172; Williamson, 1955-57, p. 312). It is far more likely that this figure is St. Barbara, as traces of her crown and three-windows golden tower can be seen. The first panel of the third bay features a bearded saint, which is most likely St. Christopher as the infant Christ can be detected. The next image is of the empress, St. Helena, whose famed quest for Christian relics sees her on display here with the true Cross in Jerusalem (James, 1930, pp. 171-172; Williamson, 1955-57, p. 312). The next two images in this bay are a crowned male and female saint, with the latter possibly being Mary Magdalene or Martha. The fourth bay features four additional extrabiblical saints; including St. Appolonia, St. Alban (James, 1930, pp. 171-172), St. Zita, and St. Sebastian, all wielding their respective symbols: a horn, discus crucifix, key and 
arrows. It should be noted the 14 visible images are evenly distributed between male and female saints.

The fragments of another panel from a lost bay, which continues the text from the First Epistle to Timothy found in the preceding bay, features a rare representation of the Risen Christ, adorned with a golden nimbus and cloak. The visible wounds also suggest this image is actually of Christ as the Man of Sorrows, a common depiction associated with medieval devotion to the wounds of Jesus. This particular motif had strong ties with the Binham monastic order, as St. Gertrude of Helfta, a thirteenth century German Benedictine, was an early devotee to both the wounds and Sacred Heart (Elkins, 1997, p. 727; Barratt, 1991, pp. 19-25; Finnegan, 1991, pp. 131-143). While this image cannot truly be classified as a medieval survival, it should be noted it does feature one of the rare instances in this study of Christ being found painted on a dado panel (Great Snoring and Houghton St Giles are the others). Duffy (2012, pp. xxxv- xxxvii) explains that the usual purpose of these screen decorations were display the divine intercessors, all lined up beneath sculpture of the triumphal cross of Jesus. This not only established a hierarchy amongst Christ and his saints, but also created a metaphorical divide between the laity and the clergy who operated on the other side of the partition. The choices to cover these panels with passages from Scripture represents the desire of the reformers to establish a new sense of holiness; rather than idolatrous images reinforcing a divide between Christ and man requiring mediation, the use of text redefined holiness as an internal experience, informed by Scripture and filled with personal accountability. 


\section{Biblical Passage}

Be sober, and trust perfectly on the grace that is brought vnto you by the declaryng of Iesus Chryst as obedient chyldren, that ye geue not youre selues ouer vnto youre olde lustes, by whych ye were led, whan as yet ye were ignoraunt of Christ: but as he which called you, is holy, euen so be ye holy also in all maner of conuersacion, because it is written. Be holy, for I am holy saithe ye lord. (1 Peter 1:13-16 - Great) Holy and beloued, put on tender mercye, kyndnes, humblenes of mynde, mekenes, longe suffrynge, for bearynge one another, and forgeuynge one another, yf any man haue a quarell agaynst another: as Christ forgaue you, euen so do ye. Aboue all these thinges put on loue which is the bonde of perfectnes. And the peace of God rule in youre hertes: to the whych peace ye are called in one body. And se that ye be thankfull. (Colossians 3.12 b to 15 - Great)

Be ready allwayes to geue an answere to euery man that asketh you a reason of the hope that is in you, and that with meaknes and feare: hauynge a good conscience that where as they backbyte you as euyll doars, they maye be ashamed, that falsely accuse your good conuersacion in Chryst. For it is better yf the wyll of God be so that ye suffre for well doynge, then for euyll doinge. (1 Peter 3.15b to 17 Great)

Godlynes is greate ryches If a man be content with that he hath. For we brought nothynge into the worlde, nether maye we cary any thynge out. But when we haue fode and rayment we must ther with be content. They that wylbe ryche, fall into temptacyon and snares, \& into many folysshe \& noysome lustes, which droune men into perdicyon \& destruccyon. (1 Timothy 6.6-9-Great)

For Couetousnes is the rote of all euell, which whyle some lusted after, they erred from the faith, and tangled them selues with many sorowes. But thou man of God, flye soche thinges: folowe righteousnes, godlynes, faith, loue, pacience, mekenes: fighte a good fighte of faith: laye honde on eternall life, where vnto thou art called, and hast professed a good profession before many witnesses. (1 Timothy 6.1012)

\section{Saint}

S. Michael

S. Katherine

Jugs

Female

S. Barbara

Covered

Covered

S. Christopher

S. Helena

Crowned Male

Crowned Female

S. Appolonia

S. Alban

S. Zita

S. Sebastian

Risen Christ

Man of Sorrows

Table 21: Screens: Binham 

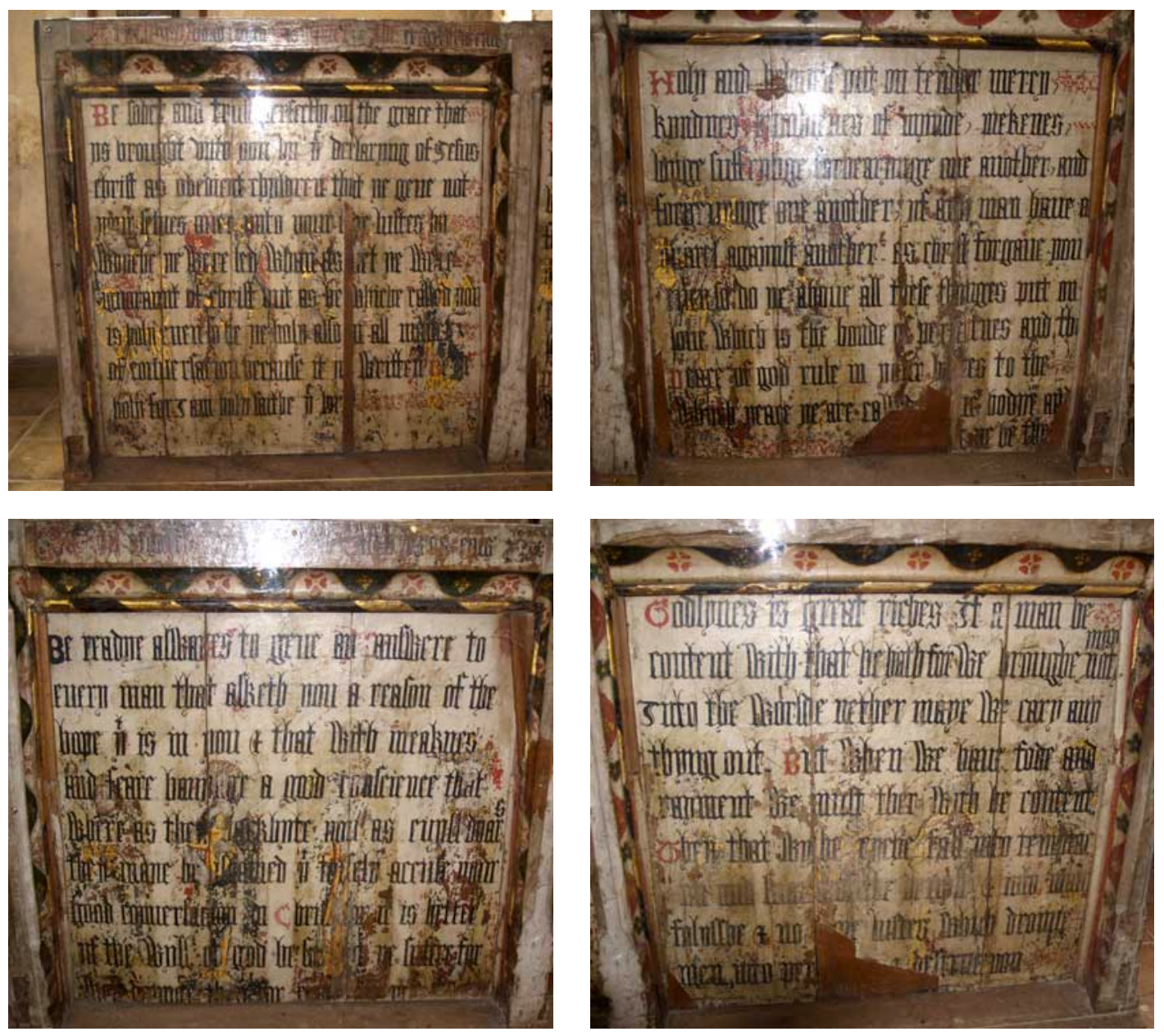

Plate 57: Screen: Binham

Bay 1, 1 Peter 1:13-16; Bay 2, Colossians 3.12b to 15;

Bay 3, 1 Peter 3.15b to 17; Bay 4, 1 Timothy 6.6-9

(Photo: Binham Priory) 


\section{Case Study: King's Lynn St. Margaret}

Lynn, located east of the River Great Ouse, was formally established in the wake of the Norman Conquest through the creation of a new parish church and marketplace. The towns proximity to the river provided access to the Wash, a sizable bay and estuary, and thus the North Sea. The commercial potential of this location was recognized by Bishop Herbert de Losinga, who engineered the plan and set Lynn on the path to emerging as one of the most important trade ports in England. Merchant guilds, most notably the Hanseatic League, dominated power in the city, evidenced by two surviving fifteenth-century warehouses.

The original Norman construction of the parish church and priory was funded through a scheme conceived by de Losinga, where indulgences were granted to anyone who contributed to the construction, in conjunction with marshaling all of the town's tithes and ecclesiastical dues (Blomefield, 1808, pp. 476-533). In addition to serving the parish with a new church, a small Benedictine priory, established under the auspices of the priory operating at Norwich Cathedral, provided the bishop with an effective means to manage the western reaches of his diocese. This was achieved through a high steward, acting in an official capacity on behalf of the episcopacy (Blomefield, 1808, p. 617). In the subsequent centuries, the wealth and prestige of the priory resulted in extensive rebuilding of the church to help accommodate the boom in population arising from the diversion of the Great Ouse following a flood. By the fifteenth century, the prosperity of the town's merchants, and members of the Trinity Guild, resulted in an extensive expansion of St. Margaret's.

On the eve of the Reformation, Bishop's Lynn, as it was known, was granted a town charter by Henry VIII, and finally acquired a mayor and corporation (Tittler, 1998, p. 228). This cemented its status as one of the most important urban centers in the county, second only to Norwich itself. Despite its prominence, the diocesan and monastic ties, dating back to de Losinga, ensured that parish would endure significant changes resulting from the Tudor seizure of monastic lands. In 1538, the priory was dissolved with some ancient rights, such as presenting a curate or minister to the church, being granted to the newly formed secular college at Norwich Cathedral (Anon., 1781, p. 208). This type of continuity did not extend to the four friaries, as each was dissolved 
and sold within the following decade to John Eyer, a Norfolk gentleman from the nearby village of Narborough (Cotman, 1838, p. 39). The connection between the bishop and the town was further ruptured, as the corporation purchased the parish church of St. Margaret, while Henry took control of the episcopal interests, including presenting a curate or minister to this church. This resulted in the colloquial name of the town being changed to King's Lynn.

As with other port towns, Lynn appears to have been more theologically liberal than some of the more rural areas across Norfolk. As early as the previous century, Margery Kempe, a Christian mystic born in Bishop's Lynn, remarked the excitement the town felt in anticipation for a visiting Franciscan preacher (Taylor, 2005, p. 31). Once the town corporation took control of the church and enticing benefits were offered to attract new preachers to the parish; including a competitive salary and the option to hold more than one post (Anon., 1781, pp. 208-209). This hunger for learning can also be seen in a new grammar school, founded in 1534 (Brown, 1903, p. 174)

The physical remains of the priory, which was situated on the south side of the church, was partly demolished in the wake of the dissolution in an effort to enlarge the churchyard (Chambers, 1829, p. 410). It is possible the church's rood screen suffered damage or removal during the excesses of the Edwardian regime, or as a result of the aforementioned renovations. Robert Whiting (2010, p. 17) mentions a precedent set in Stratton, as a screen was taken down following the suppression of a religious guild. It is possible that a medieval screen here was lost at some stage of what was to prove prolonged separation between the church and the physical remains of the dissolved priory. By early in the reign of Elizabeth I, the church was in need of new chancel screen to be in compliance with a decree by the young queen commanding a partition exist between the nave and chancel of a parish church and to commission one should it have been removed (Church of England, 1825, p. 179; Whiting, 2010, p. 17). In 1584, a new wooden screen was constructed to separate the nave from the choir (Pevsner \& Wilson, 1999, pp. 118-19), most likely at the instigation of the churchwardens (Plate 57). While there is no evidence of precisely what this screen looked like upon its completion, it featured two rows of ten small arches, a lower row of blank arches and an open doorway to the far left. We can imagine this barren piece of Elizabethan 
church furniture, devoid of any decorative motifs and providing the minimum requirements as defined by the royal edict. Minimal carved text appears to have been the only embellishment, including three sets of initials and the year 1584. In addition to the initials of the churchwardens, R.C and L.R., the initials of the queen are also on display as E.R., Elizabeth Regina (Beloe, 1899, p. 107).

The austere aesthetic of this screen, a hallmark of Reformation design, was soon targeted for beautification; which was part of a broader early seventeenth-century trend to restore houses of worship to their former glory and anticipated the Laudian innovations in the subsequent decades (Spraggon, 2003, p. 134). The methods employed to achieve this would be in sharp contrast to the medieval use of religious iconography, as secular or textual biblical motifs were often selected; in this case at the instigation of Thomas Gurlin, mayor of King's Lynn in 1621 (Mortlock \& Roberts, 2007, p. 163). In addition to Gurlin's name and the year, a heraldic phrase honoring James I is carved along the upper tier: Beati pacifici Henricus rosas - regna Jacobus. The continued use of Latin, which was usually reserved for Catholic affairs, was still appropriate in relation to royal inscriptions throughout the Reformation since the Ecclesiastical Appeals Act of 1532, where the English monarchy was redefined as sharing an unbroken lineage with the ancient Roman imperial crown (Muldoon, 1999, p. 128). This phrase is packed with political and theological implications, as it demonstrates a new set of standards for church decoration. The first portion of the inscription, Beati pacifici, serves a dual purpose. First, it is a direct quote from the Gospel where Christ extols the virtues of being a peacemaker (Matthew 5.9). Second, this phrase was the personal heraldic motto of James I (Pinches \& Pinches, 1974, pp. 168-169), who always saw himself a Rex Pacificus more in lines with a wise biblical king rather than a pagan emperor (Doelman, 2000, p. 73).

The remaining portion of the inscription, Henricus rosas - regna Jacobus, translates to the Henry (VII) united the roses, but James united the kingdoms. The fact that James' accolade was a bloodless affair, where Henry's was achieved at Bosworth, would not have been lost on contemporary eyes reading this text. In terms of legitimacy, this phrase also creates unbroken continuity between the two royal houses; bound together in Reformation and the continued work to define and refine the Church of England. 
King's Lynn's unwavering support for the Stuart monarchy extended into the early stages of the Civil War, as the town fought for Charles I against the earl of Manchester for nearly three weeks in a losing effort. Within a few months, the mayor and corporation shifted their allegiance to Parliamentary forces and even invited Oliver Cromwell for a visit (Chambers, 1829, p. 409). With a harbor that could handle over 200 ships, this was a tactical victory for Parliament, which no doubt played a role in their ultimate victory over Charles.

The screen survived, unmolested in its seventeenth century form, and was repurposed as a crossing screen to partition the shallow northern transept, which itself separated the nave from the choir. The new function of the screen was to protect a valuable organ purchased by the parish, built by Johannes Snetzler in 1753, before being installed the following year. This screen remains ones of the finest example of post-Reformation furnishing architecture, as its decorative history embodies the emerging trends and styles that defined the tumultuous identity crisis experienced by the Church of England during the sixteenth and seventeenth centuries. 

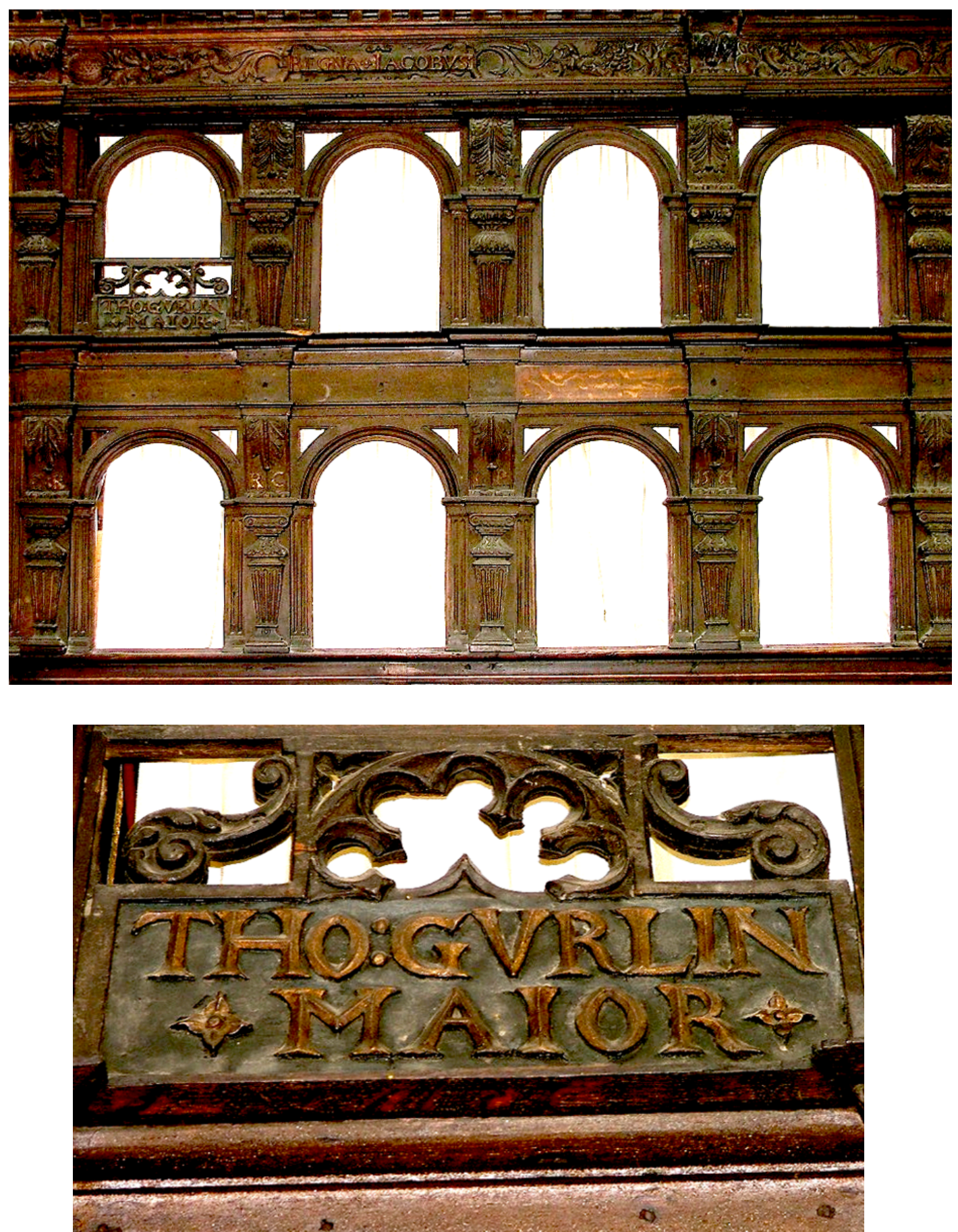

Plate 58: Screen: King’s Lynn St Margaret 


\section{R-NE Sample}

In spite of boasting the highest population of screens across all four samples (36), this group does not possess a single post-Reformation screen or decoration. As we will discuss in the next chapter, this may be attributed to a smaller monastic influence found in the sample, which would have endured less upheaval resulting from the Dissolution.

\section{R-S Sample}

This section will examine two rood screens located in the parishes of Attleborough and Hardwick. Both screens are medieval survivals that were repurposed and adorned following the Reformation, with the former featuring passages of from Scripture and Anglican heraldry. The Hardwick screen retains an inscription commemorating the parish churchwardens, demonstrating a prevailing emphasis on secular authority again. This extended as far down as a lay official and as far reaching as the repeated use of royal arms, such is emblazoned on a screen located at the parish of Wilby.

\section{Case Study: Attleborough}

Attleborough provides a case study for the impact the Reformation had on collegiate churches, where a college of canons conducted the liturgical functions of the church. These secular clergy, who answered to the warden or master, were not required to live together or renounce personal wealth like their monastic counterparts. The church at Attleborough began as a modest Norman construction dedicated to the Assumption of the Blessed Virgin; until its first major expansion of the south transept to house the Chapel of Holy Cross. This addition, funded by the Mortimer family, was soon joined by a chapel added to the north transept built by Thomas Chaunticler in 1379. It was during this period that Sir Robert Mortimer founded the College of the Holy Cross, which was conceived as equal-part parish church and secular chantry commissioned to pray for the souls of both Mortimer and his wife Margery. The college itself was endowed with five chaplains who could operate exclusively in the original parish church, which necessitated the construction of a new nave and aisles to serve the daily liturgical needs of the town.

The early phases of the Reformation had a profound and damaging effect on the church at Attleborough, which began with John Claydon, the last Master of the College of the 
Holy Cross, capitulating to Henry VIII in the wake of the Royal Supremacy in 1534. Six year later, Claydon's death ushered in the formal dissolution of the college, with the collegiate assets being bequeathed to Robert Radcliffe, first earl of Sussex and prominent royal courtier. Seeing no need to maintain the physical fabric of his new acquisitions, Sussex had his portion of the building partially razed and stripped of all valuables and plate, including monumental marble and brass. This incursion into a building, which was still nominally part of the parish church, anticipated many of the Edwardian reforms still to come, including the Chantries Act of 1548 and the confiscations of 1553.

The parish church of the Assumption of the Blessed Virgin possesses the longest, and one of the most magnificent, rood screens in East Anglia (Plate 58). At nearly fifty-two feet in length, this partition extends beyond the nave and into the northern and southern aisles. The entire screen is comprised of twenty-four arch bays, sitting atop a dado. While the middle four bays merge into a single cusped ogee arch to form a doorway, the remaining bays are predominately open with the exception of six solid panels. This late medieval oak fitting was most likely constructed under the auspices of John Heyhoo, rector of the church from 1470 to 1478, and funded by several wealthy donors. The names of several of these benefactors are visible across the dado transom and at the base of several of the panel painting. The southern trio of these bay panels features the Trinity, flanked by St. Thomas of Canterbury and St. Bartholomew, and retains the name of the donors, Richard and Margaret Hart, along with the letter 'O'; no doubt all that remains of the Latin inscription orate pro animabus, asking the parish to pray for their souls. A local religious fraternity, the Guild of All Saints, who no doubt suffered suppression along with the chantries in 1547, provided the St. Bartholomew panel, featuring the flaying knife of his martyrdom.

The northern trio features both St. John the Baptist and Evangelist flanking the Virgin, to whom the church is dedicated. It has been suggested that this group of images bears the influence of Heyhoo, between the uses of two saints name 'John' and his possible visual depiction in the Virgin panel (Marks \& Williamson, 2003, p. 238). These images are all hallmarks of medieval iconography. 
The Reformation resulted in a series of alterations to the screen over the subsequent century, which began with godly additions and evolved into more formal high church aesthetic. As its new owner was raiding the older portion of the building, the screen became a crucial barrier, which allowed the church to continue to serve its parishioners; a sharp contrast from its original purpose of ensuring privacy for the prayer of the benefactor's souls. At some point during the remainder of the Tudor century, the entire structure was whitewashed and adorned with Scriptural text across the upper transom:

Put thy trust in God with all thyne herte: and leane not vnto thyne awne witte. In all thy wayes haue respecte vnto hym: \& shall order thy goynges. Be not wyse in thyne awne conceate: but feare the Lorde, and departe from euell: so shall thy nauell be whole, and thy bones stronge. (Proverbs 3.5-8 - Great Bible 1540).

This passage, within the context of the Reformation, can be interpreted as in either support for the religious upheaval or as a veiled warning against such changes. The former interpretation implores the congregation to resists their own impulses and understanding of their faith in favor of allowing God to pave the road ahead, which would no doubt lead in a Protestant direction. The latter interpretation could be suggesting that the reformers are those leaning on their own understanding and are wise in their own conceit. Regardless of the intent, text was the primary decoration to be seen on the otherwise barren screen for the remainder of the Tudor reign.

By the start of the seventeenth century, the new Stuart monarchy coincided with a new appreciation for hierarchy and order by the parish at Attleborough. In 1615, John Forbie, the rector of the greater part of the church, commissioned the addition twentyfour coats of arms of the bishoprics of England and Wales to be painted over the passages of scripture added in the previous century (Daggett $\&$ Sheffield, 1894, p. 776). While the Proverbs text was spared, the faint remnants of a quotation from the Epistle to the Romans can be seen beneath the over painted heraldry. This decision to supersede Reformation decoration suggests that the conflict between Catholic and Protestant had shifted to between Anglican and Puritan, with a focus on the establishment and individual faith respectively. In 1632, Forbie continued to shepherd his parish in a more formal direction as he erected a churchyard cross, complete with 
his own devotional Latin text, upon instigation from Richard Corbet, the bishop of Norwich who had recently been translated from Oxford. Fragments of this text, derived from the Book of Revelation, was painted onto two dado panels:

Blessed are they that called unto the lambes supper (Revelation 19.9).

I will come in unto him and will suppe with him and he with me (Revelation 3.20).

The modifications to this screen, performed over a century, are a physical testament to three distinct religious phases: late medieval Catholicism, Tudor Protestantism and Stuart Anglicanism. The gradual transformation of this fitting is a reminder that the Reformation was an evolution, not a revolution, in religious thought. By the seventeenth century, Anglicans who desired a formal interpretation of their faith, as seen through the return of Latin, had almost certainly lost an understanding of Catholicism within an English context. Even here, the Latin text used to adorn this screen was a translation of vernacular scripture; a dramatic testament to how far the Church of England had moved away from Rome.

The higher rate of Reformation screens and decorations seen at the $R-S$ sample provides greater opportunities to examine the emerging subject matter found within the more rural parishes. Just as the Attleborough screen is testament to the hierarchical ecclesiastical authority, the use of secular motifs became increasingly common throughout the seventeenth century. At Wilby, a fire devastated the medieval interior of its parish church, dedicated to All Saints, in 1633 (Pevsner \& Wilson, 1999, p. 117). The entire building required to be refitted, which included a new chancel screen, decorated with the royal arms of Charles I, acquired and installed four years later. 

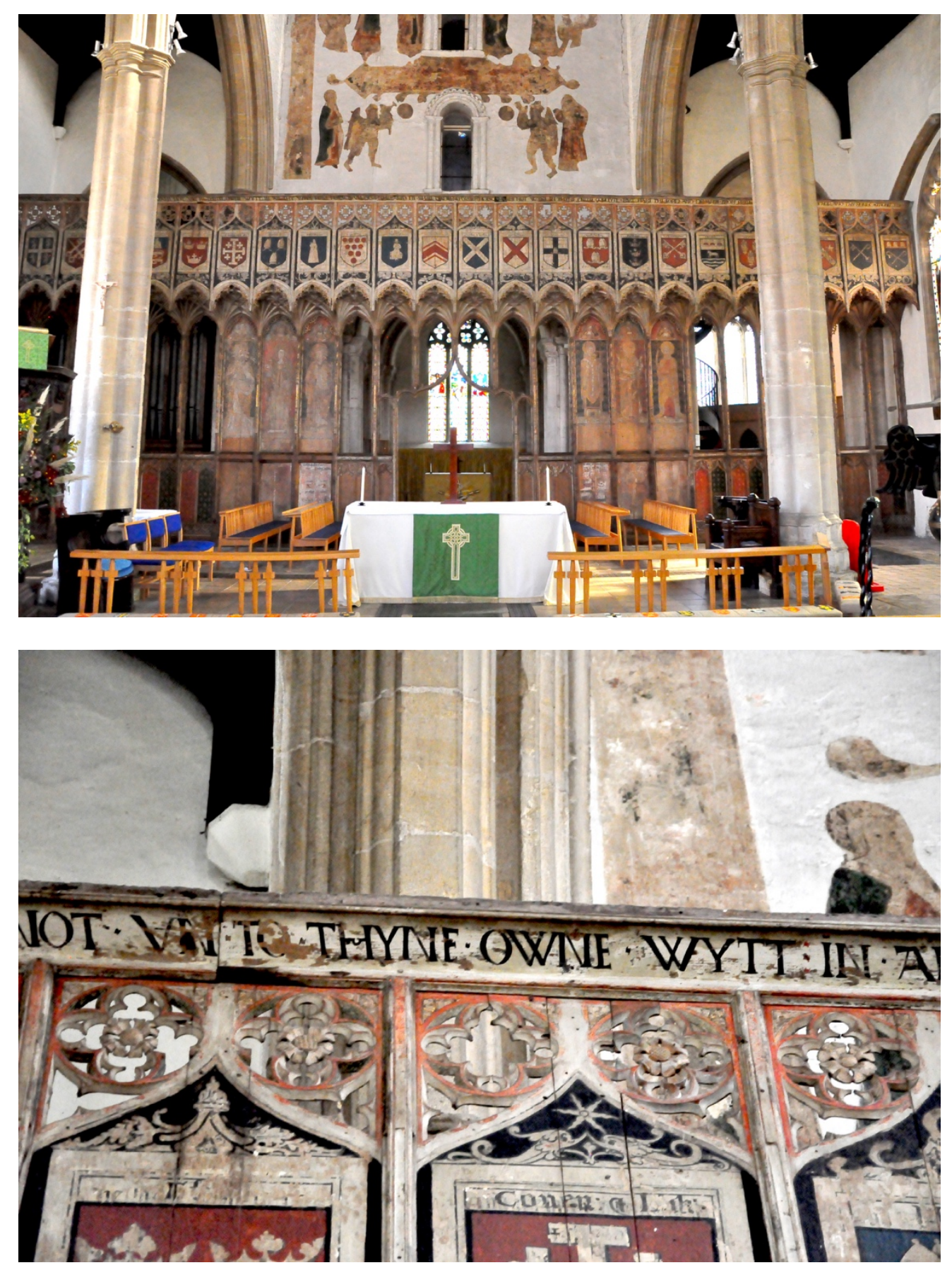

Plate 59: Screen: Attleborough 


\section{Case Study: Hardwick}

At Hardwick, another Perpendicular Gothic screen suffered waves of alterations as the religious sensibilities began to shift in the early seventeenth century (Plate 59).

Pevsner (1999, p. 381) mentions that this fitting had fallen into disrepair and required a restoration in 1611. It is possible that this screen had already been whitewashed in the previous century, as these repairs may have evolved into a beautification. The evidence for this notion comes from the fact that this screen suffered extensive damage during the Civil War at the hand of Puritans. It is possible that the upper portion of the screen was damaged during the demolition of the surviving rood loft. In the wake of this disruption to the building interior, the churchwardens arranged to repair the damaged fitting utilizing recycled materials from their dismantled loft. Adopting an open tracery design, the frieze spanning across the top of the screen features the churchwardens' names, John Ebbets and Joseph Cock (Heywood, 2013, pp. 5-6). The lack of any religious iconography, accompanying this tribute to the secular parish officials, ties into the view that the Restoration of 1660 is a more comprehensive chronological demarcation in an analysis of the long Reformation.

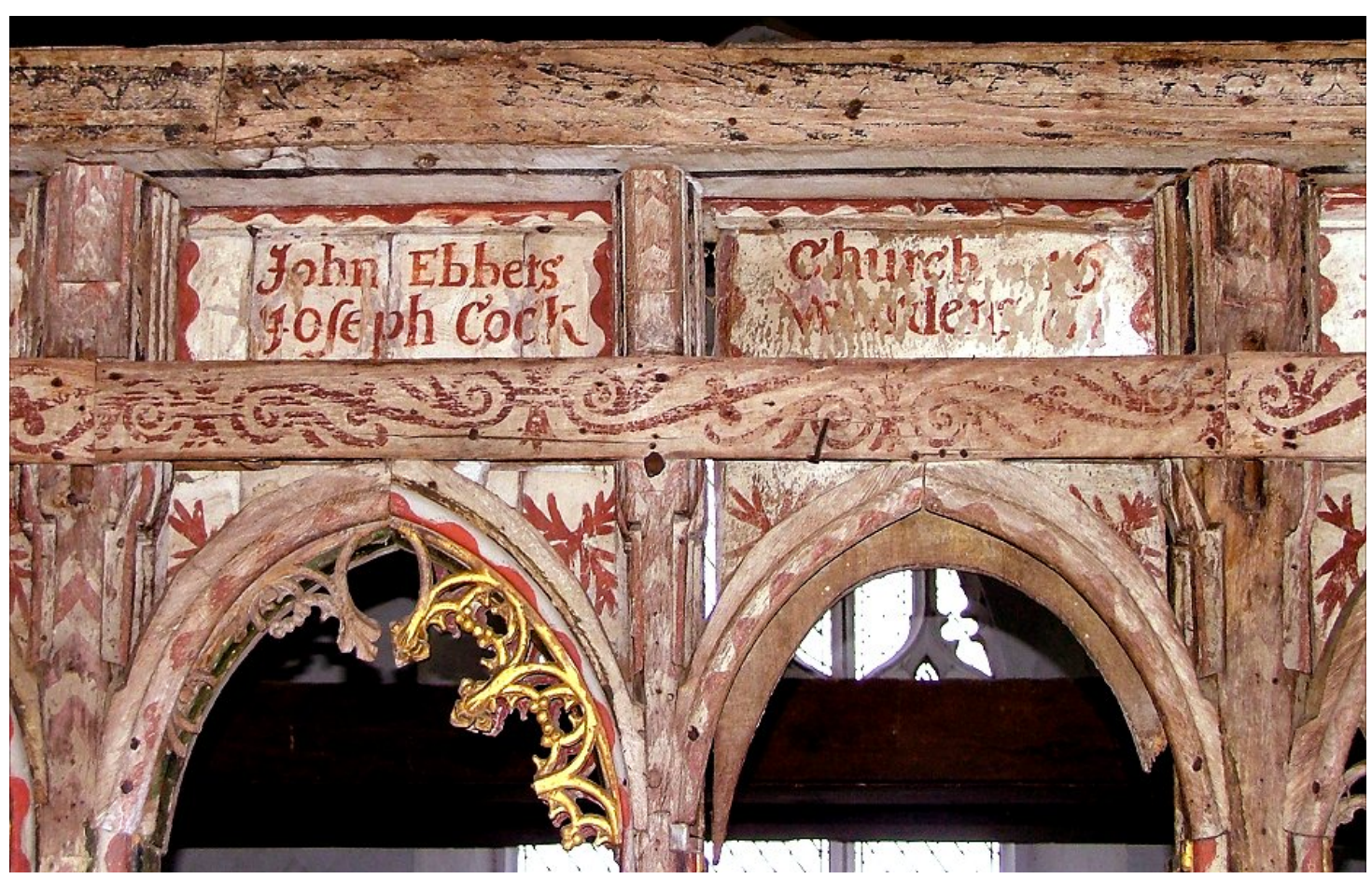

Plate 60: Screen: Hardwick

(Photo: Simon Knott) 


\section{U-N Sample}

The Norwich sample does not retain a single screen dated to this period. Furthermore, of the 6 Perpendicular Gothic screens to survive in the city, not one features any traces of Reformation-era innovation.

\subsection{Paintings - Wall \& Ceiling}

In the wake of the accession of Edward VI, royal injunctions against wall paintings resulted in widespread whitewashing of parish church interiors. Across the four sample groups in Norfolk, churchwardens reported on 19 occasions that church good were sold with the proceeds going towards financing the whitening of walls to suppress any visual depictions (Walters, 1965). These acts of merciless iconoclasm were designed to simultaneously strike off offensive images of veneration, while promoting the new austere aesthetic more conducive to a Protestant form of worship. The Edwardian regime, fueled by Cramner, sought to reshape the liturgy into one that was defined by personal devotion and the Word, both written and spoken. The newly barren interior walls certainly served this purpose, by both brightening the space and preventing any distraction while the pastor delivered his weekly message. Even so, the visual 'real estate' value of these walls was far too important for the marketing of the new theology to be left unadorned. If parishioners wanted to gaze upon the walls, they would no longer be greeted by towering portrayals of St. Christopher or graphic depictions of the Last Judgement. Instead, vernacular passages from the Bible emerged as the preferred visual expression. Both case studies are pulled from the $R-N W$ sample, as only the parishes of Thornham and Cockthorpe feature Reformation-era innovation in wall paintings. This can be attributed to subsequent Victorian campaigns to uncover the medieval wall paintings lurking beneath the whitewash and text (Newham, 2014), an ironic iconoclasm of iconoclasm.

\section{Case Study: Thornham}

The implementation of passages pulled straight from the Bible can be seen at All Saints in Thornham on the western nave wall. As opposed to using the walls as a glorified billboard to impart a concise message, such as the Commandments or Lord's Prayer, the traces on display appear to have saturated the space with extensive passages from 
New Testament (Plate 60). The faded remnants are pulled from the fifth chapter of the First Epistle to Peter, written in a similar script to the two passages from the same book found on the modified rood screen panels found 15 miles to the east at Binham. Cases like this demonstrate the transformation of priorities in regards to the humanities, as these whitened walls became less an open canvas for artistic expression and more a blank sheet of paper waiting to be publicly marked with sacred text.

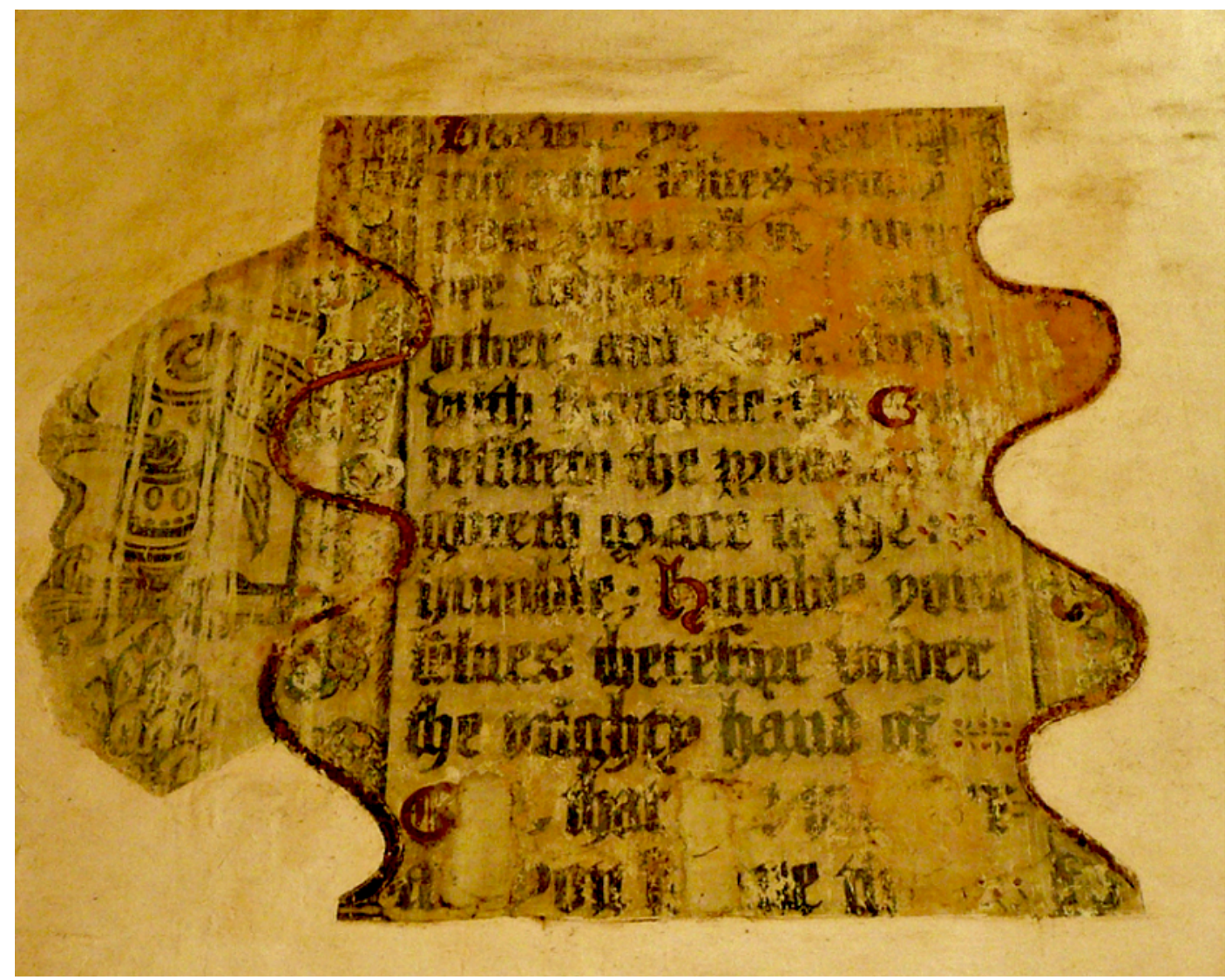

Plate 61: Wall Painting: Thornham 


\section{Case Study: Cockthorpe}

Following the ascension of Elizabeth in 1558, it was apparent that the preceding decades had produced a disorganized state church with a muddled religious identity that was in dire need of a practical uniformity. By 1560, the queen set out to reform the Reformation by acknowledging the disorder which had descended on parish churches and providing a series of prescriptions to help build on the Protestant aims of her younger brother, while maintaining a hierarchical infrastructure with the Crown at its zenith. The appearance of religious institutions could not be one of dilapidation, as strength and order remained the laities' preferred path to God, in spite of a personal component to faith which stripped the Catholic sacraments of their monopoly on salvation. To this end, Elizabeth commanded:

according to your discretions to determine upon some good and speedy means of reformation, and, amongst other things, to order that the tables of the Commandments may be comely set or hung up in the cast end of the chancel, to be not only read for edification, but also to give some comely ornament and demonstration that the same is a place of religion and prayer (Church of England, 1825, pp. 118-19; Robertson, 1869, p. 393).

The intentions of this edict could not be any clearer, as Elizabeth declared that indiscriminate destruction of church ornamentation was over; instead, a new scheme was provided which would hopefully please both conformists by offering some degree of decoration and the 'godly' through the placing of sacred, unaltered scriptural text in such a prominent location.

All Saints in Cockthorpe retains the only uncovered case of a Commandments wall painting found across all four sample groups in Norfolk. This text was uncovered in 1989 on the east wall of the chancel along with a traditional depiction of St. Christopher on the north wall opposite the entrance (Norfolk Historic Environment Service, 2007). This text is framed with a black and white border, helping create the illusion of page etched on the wall. In spite of the royal order demanding that the chancel be decorated with the Decalogue text, it should be noted that only a single instance should not be surprising as only 3 of the 65 surviving cases of polychromy are 
within the chronological confines of this study between 1534 and 1660 . This paltry rate of survival needs to be taken in the context of the subsequent centuries, which saw a revival of interest in the nineteenth century to restore parish churches to their Gothic splendor through refurbishment or restoration. Therefore, this Victorian program saw tremendous value in recovering the medieval wall paintings that were known to be concealed beneath a layer of Reformation lime and painted text. While these actions did provide visual access to some of these artistic treasures, it sacrificed a great deal of the post-Reformation innovation in an idealistic attempt to turn back the hands of time.

\subsection{Sculptures}

\section{Case Study: Aslacton}

The use of figurative stone sculpture in churches saw a significant decline in the wake of the Reformation, as the expense and required craftsmanship was difficult to justify for a potentially idolatrous decoration. As an untold number of statues were beheaded, or destroyed outright, it became increasingly uncommon to find an innovation in the medium outside of funerary monuments, which happened to see an increase in complexity to commemorate the secular achievements of its benefactors. The only case of post-Reformation sculpted work for a church fitting is a carved wooden pulpit at Aslacton in the $R-S$ sample. This modest fitting was likely constructed in the Elizabethan period, and may have been Flemish in origin (Pevsner \& Wilson, 1999, pp. 184-185), although it has been suggested that it could be a later innovation (Plunkett \& Plunkett, n.d.). The subject matter chosen for the lectern portion of the pulpit is a relief carving of a young David as depicted in the Old Testament following this defeat of the Philistine Goliath (Plate 61; 1 Samuel 17). The future king of Israel is shown striding forward, holding the head of his slain opponent in his left hand, with a smaller carving of the battle itself beneath. Within the context of a Protestant landscape, the pulpit was an integral location as the wellspring of the godly preaching; a movement which no doubt identified itself as the underdog conqueror, like David, of the might of Catholicism. 

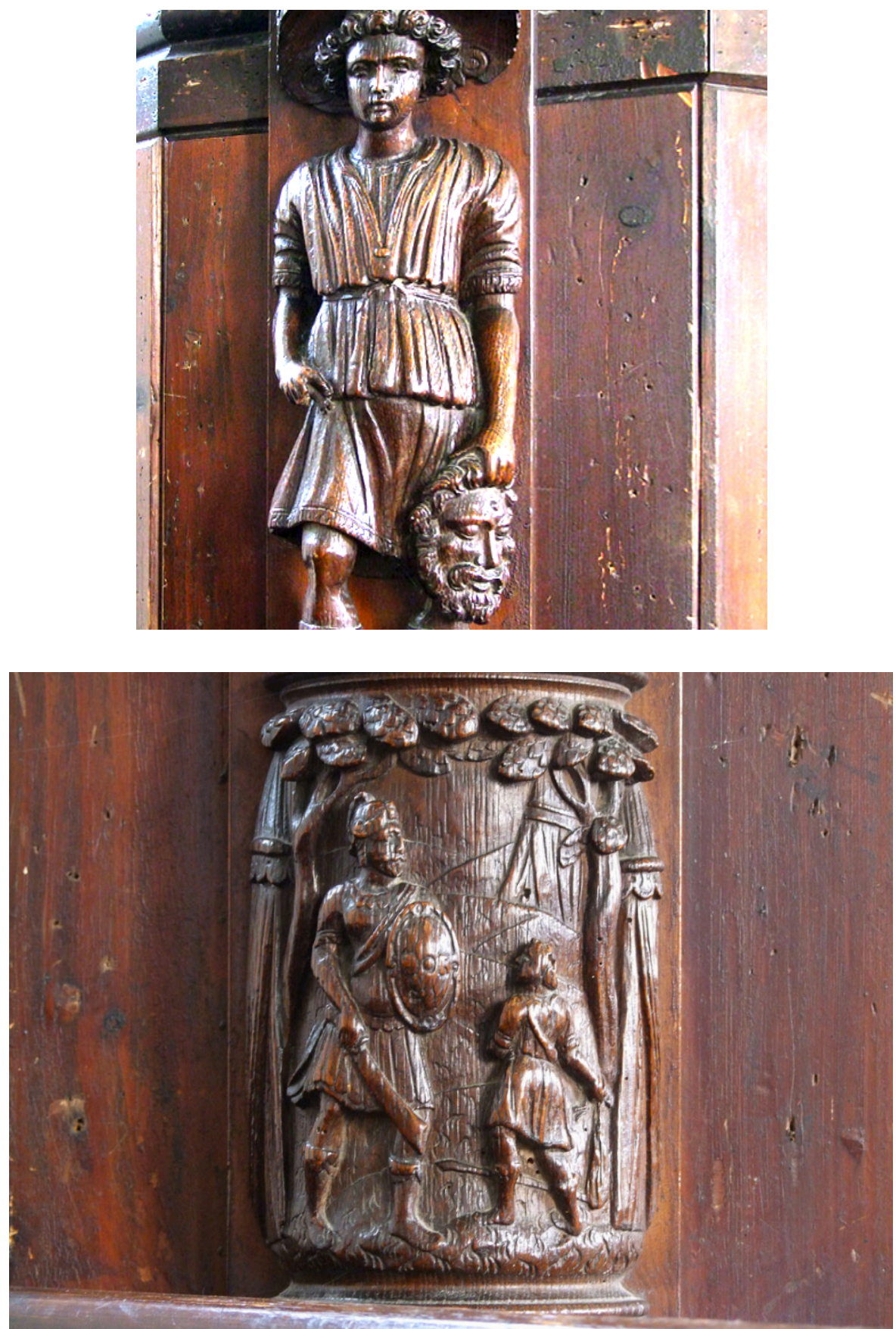

Plate 62: Sculpture: Aslacton 


\subsection{Communion Rails}

As the notion of sacrality in regards to the Eucharist was demoted within the Anglican Communion through the removal of the transubstantiation doctrine, the location within the church where the previously miraculous transformation of the gifts occurred was stripped of hallowed status. This challenged the need for a permanent fitting designed to partition this space, which can be observed as only an average of $30 \%$ of screens survives across all four samples. Like fonts, this fitting would have been found in every parish church before the Reformation. While some screens have been lost in more recent times, or even replaced by the Victorians, most screens would have been removed in the period leading up to 1660 . The hasty removal of these screens, as opposed to destructive modification to any offensive iconography, failed to realize the practical importance these boundaries provided and required the introduction of new fittings to serve a similar purpose.

The introduction of altar, or communion, rails during the Reformation solved this dilemma; as they offered a central location to administer the Eucharist, but did not hide the preparation or liturgy. These low barriers were akin to rood screens that had their upper tracery removed, leaving only the bottom dado panels behind and allowing for modest division between the laity and the clergy when needed. In the Norfolk samples, all cases of these railing are post-Reformation innovations, with the only exception being one found at Taverham in the $R-N E$ sample; although this was originally a screen transferred from the church at Booton in the 1870s and was repurposed as rails (Knott, n.d.). While no rails have endured in the urban sample, the three rural samples have 15 cases, with $R-N W(5), R-N E(8)$ and $R-S(6)$. The modest rate of survival is to be expected, as most churches still had modified rood screens which served the same purpose. Furthermore, the nineteenth-century campaigns of beautification would often have needed the space for the introduction of iron chancel screens, resulting in the removal of these modest partitions.

A clear correlation between screens and communion rails is inconclusive; although, a higher rate of survival of rails does correspond with the lower rate of survival of 
screens. While this could suggest that churches stripped of their screens were obvious candidates to be outfitted with altar rails, a definitive conclusion cannot be drawn.

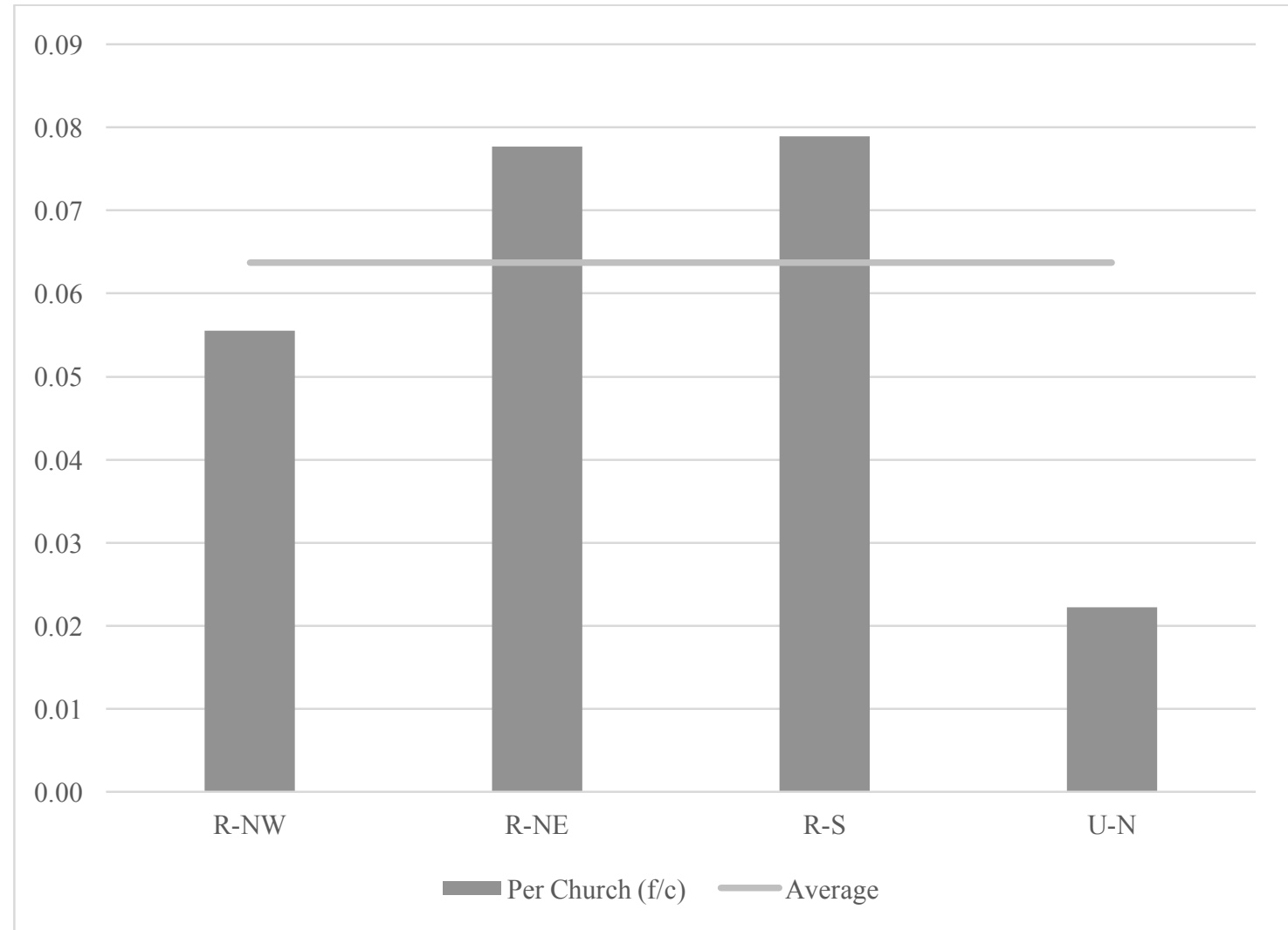

Figure 17: Communion Rails: Per Church

\subsection{Pulpits}

The Reformation ushered in a transition in preaching, which was now seen as the audible manifestation of the Word. While pulpits did not emerge a Reformation innovation, their importance and prestige were bolstered by injunctions instituted by the central governments to promote the new religious orthodoxy and even political propaganda. Under Edward VI, preaching outside of a parish still required a license, however, a beneficed priest could preach whenever they wished. The government ordered that a minimum of eight sermons be given a year in each parish, with four of being written in opposition to the papacy and in support of the Royal Supremacy (Cox, 1915, p. 82). The Elizabethan Injunctions of 1559 continued this trend, which resulted in an entire generation of clergy needed to be familiar with vernacular Scripture and 
dynamic speaking, while forgoing any knowledge of Latin or classical learning. The tenuous position of the Church of England during her reign actually resulted in sharp decline in preaching, as the clergy did not want any trouble by inadvertently empowering either the Catholic holdovers or the zealous Protestant upstarts. Instead, the pulpit emerged as the primary method of the distribution of political propaganda and helped create the cult of Gloriana, where the prestige of Elizabeth helped foster public order and even replace the pre-Reformation cult of the Virgin (Strong, 1977, p. 17)

The following century saw a dramatic increase in the innovation of new pulpits, as the Jacobean government ordered the churchwardens of every parish to provide their church with a pulpit (Cox, 1915, p. 86). With the immediate fear of a Catholic resurgence fading away, preachers were emboldened to provide sermons which promoted their vision for the Church of England. Across all four samples, the $R-S$ features the most post-Reformation pulpits with 13, which can be attributed to the lack of any medieval survivals. The $R-N E$ sample remains consistent, as 9 medieval pulpits are matched by another 10 innovations. The $R-N W$ features lowest rate of survival across the rural groups with 5 before and 5 after the Reformation. Finally, not a single pulpit survived at the parish churches Norwich, as the only one accounted for is a fifteenth-century fixture located at the Cathedral.

The Jacobean resurgence in pulpit construction and restoration resulted in more churches being outfitted with these wooden fixtures than ever before. This appears to have been the case at St. Peter in Great Walsingham in 1613, when a medieval pulpit was restored from materials salvaged from a dismantled rood screen or rood loft. The Jacobean mandate for the installation of pulpits could also coincide with need for a local benefactor to mark their position within within the parish. At St. Andrew church in Frenze, a carved wood pulpit, with canopy and sounding board, was constructed at the same time as a row of family pews (Pevsner \& Wilson, 1997, p. 118). At All Saints church in Tibenham, a towering wood pulpit and canopy was installed north-east corner of the nave. While pulpit from this period do not feature the figurative paintings of their medieval forebears, pulpits like this demonstrate a similar aesthetic trend seen on contemporary century screens, including elaborate decorative carvings and gilded trim. 


\subsection{Conclusion}

The innovation of new church fittings examined across the four samples groups in this chapter demonstrates the shift in power from the clergy to the laity and from ecclesiastical authority and church tradition to the vernacular text from the Bible. New fittings were often adorned with decorative carvings of different degrees of complexity, while donors name would be emblazoned for all of the parish to see. These could also include the arms of a local family, bishops or even the monarch. In other instances, existing fittings were often modified through the application of whitewash and the addition of passages pulled directly from the Bible.

Fittings created or modified in the period between the 1534 Supremacy and the 1660 Restoration reveal the core explanation as to why the Reformation successful shattered England's relationship with a strong and vibrant Church, it gave everyone in the realm power. As the state assumed the control over religion and social welfare, local authorities saw the scope of their power broadened in order to successful carry out the directive comings from the central government. More than ever before, men of ability were in a position to bolster their standing in spite of their birthright. As for the rest of the laity, access to the Bible provided the option to master of their own spiritual destiny as long as it was conducted within the confines of a conformed Anglican liturgy. These two simple conclusions drawn from the evidence seen across all four sample groups cannot be overstated, as how this ties into the wider themes and research questions, will also be assessed the Chapter VII discussion section. 


\section{Chapter VII: Discussion}

The evidence presented in the previous three chapters has demonstrated that the survival, destruction and innovation of church fittings during the Reformation were the result of a series of complex transitions in the understanding and relationship between parishioners and their religion. This chapter will engage the research questions associated with the four themes laid out in Chapter II, making use of the case studies and statistical data presented in the preceding three chapters. The intent of this discussion to summarize these findings and explain why and how these things survive in the forms they do.

\subsection{Iconoclasm}

Iconoclasm remains one of the most evident and compelling themes in the archaeology of the Reformation. The assessment of iconoclastic activity has revealed a sophisticated comprehension of images and their meaning. This 'intelligence' in the destruction of objects of ritual or veneration reveals that the centrality of the Bible to the new religious paradigm was one element of reformed theology understood by those tasked with renovating church interiors. Just as it has been argued that images of figures were defaced in a method which reflected capital punishment, this calculated approached to iconoclasm should fully dismiss the association of damage with mindless vandalism. It has been overstated that the heads and hands of images were targeted regardless of if the saint or religious persona was male or female, religious or lay (Graves, 2008, p. 47), as it has been seen that in many instances the religious personas found in the Bible were afforded a unique 'stay of execution' while other images which were part of the same assemblages were defaced.

The case studies and statistical data suggest the nature of iconographic depictions did contribute to the survival, reuse, defacement, destruction or innovation of an artifact. Fittings adorned with iconography inspired or taken directly from Christian scripture were far more likely to survive uninterrupted than one derived from an extrabiblical source. The statistical evidence demonstrates that the latter were defaced or damaged at nearly double the rate of the former; this is a staggering testament to the 
sola scriptura, by scripture alone, doctrine emerging as a defining theological characteristic of the Reformation.

Although rood statues were removed from all churches, Christ himself was still one of the most prominent icons to survive. This occurs specifically: within a narrative context, as seen on the font at Sloley or cloister roof bosses at Norwich Cathedral; a symbolic form, such as the font at Irstead featuring the Instruments of the Passion; or even as eschatological portrayal, as seen in Last Judgement wall paintings and again cloister roof bosses of the Apocalypse at Norwich Cathedral. This biblical trend extends to a widespread survival of images of the Apostles, such as seen on the screen at Hunstanton, Cawston, and Edingthorpe. The only consistent exception to this phenomenon is the sporadic endurance of St. George iconography, who in spite of being extrabiblical, was the patron saint of England itself. While contained to a font and screen located within the urban sample, it is logical that this saint, whose standard was the inspiration of the nation's flag, would be spared on nationalistic or patriotic, if not religious, grounds.

Images culled from Roman Catholic tradition were far more likely to suffer acts of iconoclasm. The case studies examined reveal that the stronger connection an image had with Church tradition, the more offensive it was found to be. Fonts decorated with carvings depicting the seven sacraments, as discussed at Binham, Burgh-next-Aylsham, St. Mary in the Marsh, and Gayton Thorpe, all suffered varying degrees of mutilation. This is entirely consistent with unifying themes of the Reformation, as the true power of the Church was in its authority to administer the requisite sacraments required for salvation. An attack on these fonts was an assault on this notion, with the damaged facades remaining as a constant reminder to the parish of the new paradigm of English Christianity; equal part personal devotion and Anglican liturgy.

In spite of technically being a figure from Christian scripture, the excessive veneration of Mary, mother of Jesus, resulted in her being viewed as an adversary to the principles of the Reformation. Across all fonts and screens, 12 of 14 images of the Virgin were targeted for destruction. In addition to the vandalization of a Marian image on the font at Bridgham, which presented her as the Mother of God in majesty, the selective 
destruction of the Virgin boss sculptures of at Norwich Cathedral, especially those representing apocryphal narratives, reveal a surprisingly sophisticated understanding of what depictions were biblical and which were not.

Other extrabiblical images, such as legendary, historical and local saints, also did not fare well throughout the Reformation. The case studies reveal that such representations were incompatible with the new interpretation of Christianity, as evidenced by extreme damage done to an image of St. Barbara on a screen at Thornham also featuring Old Testament prophets, a defaced wall painting of St. Christopher at Hardwick, and the disfiguring of the Latin Doctor on a font at Docking. As we will discuss with regards to the question addressing the continued liturgical use of a fitting, the St. Gregory images in the Doctors grouping often received the most abuse as a result of strong antipapal sentiments, also seen on the Bridgham font in the destruction of images of the archbishop of Canterbury and bishop of Ely.

Finally, the wall and ceiling paintings on display at Norwich Cathedral, in a room that served as an entrance to a lost reliquary, is one of the most striking cases of selective iconoclasm. Among the four grouping of saints, only the collection featuring New Testament saints remain unmolested, as the other clusters of women, confessors, and clergy were all targeted for destruction and neglect. Cases of selective iconoclasm such as this shed new light on the subtleties of reform, which for far too long has been viewed as indiscriminate and inflexible.

New fittings to emerge following the schism with Catholicism were decorated with iconography more consistent with the shift in religious priorities. In addition to the continued use of biblical motifs, both visual and textual, heraldic shields were the most common type of image seen on new fonts, which could include royal, aristocratic, family, ecclesiastical and even saintly arms. The inclusion of visual icons honoring lay authorities extended to even promoting religious figures in secular terms, as observed the use of apostolic shields on the font at Cockthorpe and even the aforementioned Instruments heraldry. 
The seventeenth-century struggle for the soul of Anglicanism saw two distinct styles emerge, with the Puritans often favoring either symbolic icons, such as a pelican font cover at St. Stephen in Norwich, or very simple depictions from scripture, like the sculpture of David and Goliath at Aslacton. High Church Anglicans, who still favored formality in matters of religion, often adopted a hybrid approach to iconography that visually appeared somewhere between traditional Catholicism and Protestantism. This was examined in cases such as a font adorned with passages from Scripture in Latin at Gaywood and English diocesan heraldry on the screen at Attleborough. While this division grew to be a contributing factor to the Civil Wars, it demonstrates that powerful bias towards the Bible, along with a strong aversion to international popery, were the key components to the religious identity of most factions in England.

The transformation of visuality and spatiality within a church were defining consequences of the English Reformation. The notion of 'seeing' and 'reading' emerged as a unified form of visual practice during this period, either through the direct use of text as decoration or selection of images based on the reading of scripture (Giles, 2007, p. 117). At Binham, the extensive passages of scripture added to the whitewashed rood screen panels were assured to be a central focal point to parishioners; just as it was at the aforementioned Attleborough. Wall paintings of the text from the Lord's Prayer, like those observed at Thornham and Cockthorpe, reinforce the sense that the written word was central to the visual component of faith. As previously discussed, this shift in visual focus did result in liturgical practice as evidence by the continued usage of Baptism and Eucharist as defined in the Book of Common Prayer on biblical grounds.

The placement of church fittings was stripped of their traditional association with eastern sacrality; however, the nature of congregation-based church services transferred the focus to the pulpit, still positioned in the eastern portion of the nave. This notion of spatial segregation and sacrality was supplanted by a practical need to conduct an organized service; with all eyes and ears fixed on the preaching and the Eucharist still taking place close to the chancel. At Edingthorpe, the surviving rood screen panel painting features St. Peter and St. Paul in the most prominent location in the center of 
the screen; a sign that 'sacrality' was now interchangeable with a more practical 'centrality.'

\section{Selective Iconoclasm}

The Reformation ushered a transformative period in English art, as visual aesthetic was intimately tied up with the theological issues in contention. Protestant thought did not merely promote a sweeping rejection of art; rather, it challenged the perceived idolatrous component of image veneration and struggled to reconcile this with the potential benefits. One of these advantages were the fact that many of these icons could actually be of use in educating the laity on both biblical virtue and history. The Edwardian regime attempted to distinguish which schemes were of value but soon forged ahead with policies that seemingly only tolerated vernacular passage of scripture emblazoned across the newly whitened wall or heraldic royal emblems.

The widespread accessibility to vernacular scripture, especially the Old Testament, provided an array of directive against any behavior which could be perceived as pagan idolatry. This denunciation of holiness, which transferred sacrality from physical touchstones to internal devotion, needed to adopt a draconian approach to dealing with church artwork if the Reformation was to be a success. Instead, the battle against idolatry was able to retain select pieces of art by merely reallocating their purpose from veneration to informational; as these images could no longer reveal truth, but could certainly bring scripture to life. While this method successful bridged the transformation of a a partially illiterate laity into congregations of the 'Word,' it left the possibility open for the centrality of these images to one day be restored. In spite of this, the remainder of the Tudor century saw these impulses satiated through both an increase in secular portraits and heraldry, text-based decoration and even a proliferation in commemorations. On a national level, images typically associated with veneration were confined to private chapels, which was entirely consistent with Elizabeth's approach to tolerating the personal inclinations of her subjects as long as they outwardly complied with all mandates set by her Church (Ricketts \& Ricketts, 2007, p. 79). On a local level, the destruction of images could become problematic as it strained the social order, as many of these images were intimately tied families who financed them as a testament to their secular legacy. In 1560, an Elizabethan edict outlawed the 
destruction of funerary monuments, however, this did little to safeguard the integrity of these memorials as a second edict was issued in 1572. In spite of offensive images or text which could be found on a medieval commemoration, this still suggests a decline in respect for the aristocracy and gentry (Heal, 2017, p. 190; Weever, 1767).

Regardless of the official doctrine flowing north from London, these issues needed to be resolved within the parishes, barring an official visitation from a royal, or later parliamentarian, official.

This schism between Christianity and artwork, resulting from imageless devotion, did not endure; as the Anglican liturgy became more reliant on the visual component of sacrality in the seventeenth century. This desire to bring uniformity and ritual to worship, championed by Charles I and Laud, required what the latter described as the "beauty of holiness." (Hooker \& Bayne, 1902, p. 61) In many ways, these policies sparked the extremism of the Rump Parliament in 1648, that desired every trace of iconography stricken from parish churches and for the cathedrals themselves to be torn down (Spraggon, 2003, pp. 197-199). In spite of this, the same factors that enabled surviving medieval images to survive until this point, local influence and Biblical content, allowed them to continue to survive until the Restoration of 1660.

The reorganization of church interiors by the mid-seventeenth century is exemplified at Norwich Cathedral by the alteration made to the ledger slab commemorating the founder of the building, Bishop Herbert de Losinga. Along with the deprivation of the bishop, and ransacking of the building, the city's Corporation assumed control of the church and immediately promoted an agenda that was equal part Puritan and secular. Sunday services now featured independent minister, appointed by the corporation, with the bishop's throne near the high altar repurposed for the mayor. The elevated ledger slab was ordered to be lowered and set within the floor, as it was directly in the mayor's line of sight (Gilchrist, 2005, p. 206). This is one of the more revealing incidents, as it concurrently demonstrates the continued centrality of visuality and the transference of spatial sacrality from ecclesiastical to secular authorities.

The unified visual promotion of text and images derived from the Bible appealed to both the literate and illiterate members of the laity, even though this notion has been 
challenged (Graves, 2007). Images of biblical figures and stories lost the component of veneration and were now seen by reformers as a visual bridge to the Bible itself. While many of the images were medieval survivals, the new additions were often textual; suggesting a desire to promote literacy as an integral devotional practice. This, combined with the oral recitation of Christian prayer also written on the walls, such as the Lord's Prayer, were no doubt designed to imprint on the memories of the faithful. This all suggests that seeing images, reading text, and hearing sermons, all derived from Scripture, must be seen as unified, and Protestant, visual practice.

This view is complimentary to that of Duffy, who speaks of the relatively uniform understanding and expression of faith across every level of society in medieval England. By the same token, the Reformation was able to succeed, in part, by a similar uniformity, driven by ease of access to the Bible, in print or illustration. The even greater emphasis placed on preaching, combined with the continuance of biblical icons, bridged the education gap in a similar fashion to that of the Catholic church. A crucial difference to emerge was the rapidly increasing literacy rates, which empowered more people across all classes to access and interpret Scripture; thus, leading to critiques and resistance to teaching being promoted by the state church.

\subsection{Authority}

The church fittings examined in this study reveal a gradual empowerment of the laity at the expense of the Church, as the prestige of lay authority, from the monarchy to local churchwardens, were all bolstered by the Reformation. Church fittings became the premiere methods to flaunt this authority, as the use secular arms on existing and new fittings rose dramatically during the period. As the Crown assumed leadership over religious affairs, local officials tasked with ensuring conforming to the new orthodoxy saw their positions and scope of authority strengthened.

As the Church was stripped of its temporal authority, its preeminence in spiritual affairs was also compromised. The ecclesiastical structure transformed into a clerical wing of the central government, with the monarch at the head and the bishops serving as royal lieutenants throughout the realm. The previously autonomy enjoyed by the Church saw 
its administrative structure overwhelmed by the state, while the Bible, even preached from the pulpit, became a direct wellspring for spiritual authority as opposed to sacramental rituals and papal decrees.

As the authority of the Church was absorbed by Henry VIII, much of the reverence previously reserved for the papacy was transferred to the Crown. This bolstered the prestige of the monarchy, which was now master of not just temporal matters, but also spiritual. The case studies observed suggest that this new paradigm did not allow for the inclusion of images that suggested otherwise, as evidenced by the severe mutilation of St. Thomas of Canterbury iconography on the screen at North Burlingham.

Furthermore, alternative motifs that suggested any type of subordination of the royal prerogative to religious authority were also no longer compatible with the Tudor power structure; this can be observed in wall paintings uncovered at Heydon and Paston of the Three Dead Kings that no doubt only survive due to whitewash.

This acclaim for royal authority appears to have extended to other components of the central governments, such as to the Parliament that passed the legislation that empowered the monarchy. This was a contributing impetus for the Civil Wars, which undermined the authority of the king in favor for some vague notion of the "people of England.' In either case, an increased emphasis on central authority provided a greater sense of a collective national experience; compounded by the struggle against both an international religious body, in the Catholic Church, and a meddling foreign power, in Spain. The targeted destruction of images with ties to these adversaries, as seen on the screens at Castle Acre and Dersingham, reinforce the idea that a nascent form of nationalism was present during this period, even at the parish level.

The influence of local authority, from the city officials at Norwich to powerful families, increased during this period; likely resulting from a combination of the continued prosperity of the wool trade to the removal of monasteries as rival landlords. Screens featuring depictions of a donor and his family, like the one on display at Fritton, suggest that this trend began on the eve of the Reformation and continued throughout the period; most commonly on funerary monuments. If a new fitting was required, as 
was the case at Ashwellthorpe and Rackheath, it provided a local family with not only the opportunity to commission it, but outfit it with their family's coat of arms.

Any remaining reverence for church authority, which was now intimately tied to the Crown, was expressed in distinctly secular terms. A continued sense of esteem was held for the Church of England hierarchy, as seen on the font at King's Lynn St. Margaret featuring a donor inscription to the bishop of Norwich and aforementioned arms found on the Attleborough screen. In spite of this, parishes still operated with very little direct interference from the episcopacy, unless an official visitation was ordered or an area was still under the control of the former priory at Norwich Cathedral, as was the case with Thornham.

\section{Central Government}

The importance that an emerging sense of nationalism played in the success of the Reformation cannot be ignored. The notion of national sovereignty in England can draw a direct path to the earliest phases of the Reformation as defined during the Henrician regime. The Ecclesiastical Appeals Act of 1532, which passed the following year, designated England as an 'empire' which could not be bound to the authority of any foreign powers (Muldoon, 1999, p. 128). While the intention in this declaration was to invalidate the authority of the Pope, it had the unintended consequences of sowing the seeds of a new paradigm where citizens would begin to identify themselves more by their English, rather than Catholic, cultural identity. The royal supremacy bolstered this transition, with the monarch now at the pinnacle a newly self-contained, and English, secular and religious hierarchy.

Across the four samples groups, the use of royal arms begins with Elizabeth I; in the wake of the divisive architect of the Reformation, Henry VIII, and the actions of his daughter, Mary I. After these two monarchs, who allowed the policies and fortunes of the kingdom to be swayed by their marital exploits, Elizabeth ingratiated herself to her people through the appearance of being wedded to the realm. The intimate connection forged between the nation and the personage of the Crown also helped transform the love of the queen into a love for England. The sailing of the Armada in 1588 created the perfect nationalistic foil, as the two foreign antagonists created during the reign of 
the Henry and Mary, Catholicism and Spain respectively, united to challenge the sovereignty of England. This crisis was a watershed event, as the nation and its beloved queen, was under siege and required a united defense of 'Englishness' (Kumar, 2015). At Norwich, the city mustered on behalf of Elizabeth and celebrated the victory with canon fire reminiscent of more modern nationalistic celebrations (Goldman, 1847, p. 9).

The two cases of royal arms for Elizabeth are on display in the $R-S$ sample at Kenninghall and Tivetshall St Margaret. The latter is part of a magnificent tympanum above the chancel arch constructed in 1587 (Pevsner \& Wilson, 1999, p. 735). The arms used here were a restoration of the traditional motif dated back to Henry IV, featuring a four-quartered design equally representing the lions of the England and fleur-de-lis of France. For a society starting to understand and value their independent sovereignty, this was a welcome change from the arms of Mary, which had merged her own with those of Philip II of Spain. This trend continued into the next century, and reign, as the arms of James I, and his son Charles I, have survived at Blo Norton and Burnham Norton, respectively. This incarnation quartered the layout yet again to make room for the Scottish and Irish royal arms, as the thrones of the three realms were unified upon the ascension of James. The implementation of this 'secular' iconography, dedicated to the supreme governor of the state church, was an expected consequence of the unique circumstances in which England separated from the Catholic faith. This use of royal heraldry, as other images ceased to be produced, suggests the successful merger of the head of church and state in the national collective consciousness.

\section{Ecclesiastical}

On the eve of Reformation, England possessed an unusual relationship with the Roman Catholic Church resulting from the medieval disputes between secular and ecclesiastical authority, geographic isolation and a unique liturgical rite. These elements all contributed not just to the break with Rome, but the method by which a Protestant successor church would be instituted.

The tumultuous relationship between church and state already had a formidable tradition in England, centuries before Henry VIII petitioned for his divorce. The 
twelfth-century clash between Henry II and his archbishop of Canterbury, Thomas Beckett, culminating in the latter's martyrdom, must have had a profound impact on the public understanding of the 'great chain of being.' It should also come as no surprise that Beckett would reemerge as a symbol for clerical sovereignty in relation to the royal prerogative. In 1538, Henry VIII proclaimed his de-canonization along with his name being purged from all books; a clear message capped off with the physical dismantling of his shrine at Canterbury and a papal accusation regarding the desecration of his remains (Tyler, 1847, pp. 228-229; Prendergast, 2003, p. 49). For those who disagreed with the Tudor innovations in religion, like Robert Spurgeon, a priest at St. Michael-atPlea in Norwich, honoring Becket became a method of protest and a sign of enduring loyalty to papal authority. This priest was charged with possessing a Sarum Missal that did not comply with the ban on Thomas's name; a potentially severe offense which was met without consequence from Norwich magistrates (McClendon, 1998, pp. 91-92).

Public displays of visual depictions of St. Thomas were an easier target for the enforcement of the royal proclamation; as commissioners merely needed to step into a church and observe if the parish was in compliance. Furthermore, the destruction or defacement of these images helped convey allegiance to the prevailing Protestant cause; fueled by either loyalty to the Crown, anti-papal sentiments or a combination of both. The severe mutilation done to a rood screen dado panel painting of St. Thomas, founded at St. Andrew in North Burlingham, is a graphic reminder of how offensive the memory of this particular saint was to the new religious order.

\section{Local}

The instigated dissolution of English monasticism played a major role in transforming social class through the increase in landed gentry. Abbeys and priories accounted for a significant amount of land throughout the kingdom, which often included patronage of various parish churches. This essentially rendered the parishioners as manorial tenants, who would have their religious lives shaped by these orders and their interests. Rural churches, like those found at Blo Norton, Tiveshall, and Dickelburgh, had a portion or entirety of their benefices owned and controlled by the Abbot of St. Edmund Bury, the wealthy Benedictine house located in Suffolk, until its suppression in 1539. It is interesting that the iconoclastic depictions found on the surviving fonts and screens in 
three churches are incredibly modest; ranging from symbols to heraldry. This should come as no surprise, as the vast controlling interests the abbey possessed often made their way to private hands, who owed their good fortune to both Henry VIII and his policies. Men, like John Cornwallis at Tiveshall St. Margaret, had nothing to gain from these assets being returned to the religious orders. This massive socio-economic transition galvanized the division and created an entire class of citizens who would remain fearful that any reconciliation with Rome could result in forfeiture of their new lands; a concern that must have created de facto Protestants in the twenty-year period between the Supremacy and the papal dispensation brokered by Cardinal Reginald Pole which enabled the new owners to retain any assets gained.

Another contributing factor to the resounding success of the Dissolution appears to be a burgeoning sense of nationalism resulting from an increasingly clear and defined sense of a distinctly English identity. The Norman heritage of the kingdom was responsible for several monastic houses still subordinate to a foreign institution, such as St. Mary Priory at Binham to Cluny Abbey in France. It should come as no surprise that these arrangements became wildly unpopular, and no doubt reminded people of persistent subordination to foreign rule that characterize the entire premise of the Roman Catholic Church. While most of these institutions were retrieved or dissolved by the fifteenth century, it set a valuable precedent which bolstered the position of the Henrician regime (James, 1896, p. 466).

A final note on the Dissolution is that many parish churches were elevated in prestige as a result of the removal of these powerful monastic rivals in the arena of religion. While some monasteries held the patronage to many churches, observed at Blo Norton, Hunstanton, Tunstead, Tiveshall, Dicklburgh, Gayton Thorpe, others even housed a local parish in their building as a tenant. As we saw at Binham, the parish church benefited from the closure of the priory and gained control of a portion of the building with the remainder being walled off and reallocated at the discretion of the new landlord. Other cases, like the parish at Castle Acre, saw the parish church elevated in status as a result of the suppression of the local priory, evidence by their appropriation of an intricate font cover. 


\subsection{Identity}

The survival and transformation of church fittings during the Reformation demonstrate the impact the Reformation had on religious, regional and national identity in England. In all cases, the endurance, modification, destruction or innovation of these materials possessed a symbiotic relationship with identity, as church fittings helped shaped people's sense of who they were while also reflecting who they wanted to be.

\section{Religious}

Two of the most formative events that assured the eventual success of the Reformation were the Henrician Dissolution of the Monasteries and the Edwardian inventories and seizures of church goods. As we observed at parishes like Tivetshall St Margaret, the wealth of the suppressed monasteries enriched the private sectors and forged a new religious identity that had its secular interests intimately tied to not reconciling with Rome. In addition, the disruption of parish life instigated during the reign of Edward aided in the dismantling of much of the physical trappings integral to a traditional liturgical religion. Churches became centers for learning, rather than experiencing, faith; which likely accounts for the survival of the Latin Doctors alongside the Twelve Apostles on the screen at Tunstead.

In spite of its often practical approaches and a relatively compliant populace, the Counter-Reformation of Queen Mary inadvertently provided the valuable ingredient necessary for the success of a Christian movement, martyrs. The work of men like John Foxe tied these events into the broader historical narrative of Christianity, with English Protestantism emerging triumphantly from the oppression of Roman Catholicism. Instead of successfully ushering a grand reconciliation with the Church, Mary associated her religion with persecution, intolerance, and subordination to foreign powers. The impact these contributions made to English religious identity were just as potent, if not more, than those made by her predecessors.

\section{Regional}

The rural samples boast a higher survival rate for baptismal fonts, screens and wall paintings, while the fittings that were more decorative than functional, like panel 
paintings and sculptures survived at a higher rate at the urban center. It stands to reason that the wealth and influence of Norwich is responsible for this dichotomy, as the city had easier access to the artisans required for these luxuries during the period covered in the study. Furthermore, the densely populated parishes endured greater wear-and-tear on those fittings that still maintained liturgical necessity; resulting in the need to replace them at some point between the period covered in this study and the present.

The iconographic depictions found on baptismal fonts saw extrabiblical images damaged at a significantly higher rate that biblical images in both rural and urban samples. In addition, secular and decorative additions fared significantly better than their religious counterparts, with the urban group performing slightly better. As we already have established, biblical icons were far more likely to survive during the Reformation as a result of the new Protestant emphasis on scripture. That being said, the socioeconomic shift taking place during, and partly due to, the Reformation saw an increase reverence for secular authority ranging from the central government, local and church officials or wealthy benefactors.

The progressive religious identity of Norwich, resulting from a pragmatic local government and its standing as a commercial hub, resulted in less overall cases of iconography, surviving or damaged, than found in the rural samples. This could also be attributed to the continued influence of the diocesan bishop, who enforced all royal injunctions against offensive images during the second half of the sixteenth century. These paltry sums of images are the cause for some inconsistency in the destruction rates found on various fittings, as 1 out of 3 extrabiblical depictions on screens were damaged as opposed to 1 out of 2 biblical images. While the rate of destruction found on fonts is consistent with the uniform results found across the rural samples, these meager cases do not allow for a nuanced conclusion in regards to acceptable iconography in the city. One of the extrabiblical images found in the urban sample demonstrates that the popularity of a patron saint with the ordinary people resulted in a mixed fate, as with a rare depiction of St. Apollonia found on a panel that survived the demolition of a rood screen at St. Augustine in Norwich. 
The three rural samples all provide examples of a uniquely 'country identity,' ranging from a decorative motif honoring agricultural labor found on the font at Burnham Deepdale to the literary folklore that appears to be depicted on the screen panels at Dickleburgh. Furthermore, post-Reformation innovation saw a pronounced increase in the prestige associated with the lay administration of a church, as seen in the addition of churchwarden names or initials on a font and screen found at New Buckenham and Hardwick, respectively. A new wooden screen constructed for St. Margaret at King's Lynn, now known as King's Lynn Minster, also featured the initials of their churchwardens and of Queen Elizabeth; while the following century continued the trend to include the name of the mayor and King James. It is interesting to note that this market town, which is embedded within the $R-N W$, paid tribute to local, municipal and national secular authority.

The $R-N E$ has the highest rate of fonts, screens, wall painting and even stained glass, followed by the $R-N W$ and finally $R-S$. The case studies examined demonstrate that monastic institutions were the most common type of landlord across the $R-N E$ and $R$ $N W$ samples, with the latter boasting more manors controlled by the aristocracy rather than the landed gentry. This is consistent with the agricultural regimes of Norfolk, as the open corn fields of the northwestern region of the county as these swaths of open land were usually dominated by aristocratic landowners. The disparate topography of the $R-N E$ and $R-S$ samples allowed landed gentry the opportunity for more landholding opportunities; however, the case studies also suggest that monastic influence was far more limited in $R-N E$, perhaps a result of its close proximity to Norwich.

It stands to reason that the modest monastic influence observed in the case studies of the $R-N E$ sample resulted in far less local upheaval following the Dissolution of the Monasteries, as landholdings did not need to be reallocated to new landlords whose interests were now intimately tied to the continued success of the Reformation. This notion is reinforced as biblical and extrabiblical iconographic depictions found on fonts in this group survived at a significantly higher rate than within the two other rural samples. It is possible that this group was geographically close enough to be influenced by the religious innovations flowing from Norwich. 


\section{National}

A burgeoning sense of nationalism, coinciding with the Reformation, can be identified in Norfolk churches, that helped expedite the break with Rome and shift more reverence towards the monarchy, and thus, to the state. The parish churches across the four sample groups provide evidence for this through both iconoclasm and innovation; as images depicting foreign church rulers suffered, while the use of royal arms emerged as a new hallmark of church interiors. The dado panels found on the rood screen at St. Nicholas in Dersingham featuring both St. Hubert and St. Denis, two foreign bishops, suffered damage along with the four other extra-biblical figures. This theme continued at St. James at Castle Acre, where a screen panel of the church's namesake has its eyes gouged out; perhaps a superstitious attempt to suppress surveillance as James is the patron saint of Spain. While not many have survived, the Four Great Doctors of Western Church motif features one papal depiction; that of Saint Gregory the Great. He is always distinguished from the other three by his tiara; a feature which transformed into a target for reformers seeking to cleanse their churches of popery. St. Agnes in Cawston and St. Catherine at Fritton both feature desecrated paintings of Gregory, with the latter featuring especially enthusiastic damage to the tiara.

As images promoting popery ceased to be produced, the transition of religious authority to the English Crown can still be seen in the parish churches through the implementation of royal coats of arms. These do not appear in the material record until the late sixteenth and early seventeenth centuries during the reign of Elizabeth and James. Four examples found in the $R-S$ sample group split evenly between the two Supreme Governors of the Church of England. The development of this motif was initially confined the south of the county and is compounded by that fact three are found in Guiltcross with another in Diss, the two southernmost hundreds in the sample. In addition to its generally closer proximity to London, these border regions were the most regularly visited areas by royal commissioners on the way to Norwich. The additional three surviving arms were found in the $R-N W$ sample with one for Charles I and two dated to 1660 for Charles II. 


\subsection{Memory}

The application of memory theory to church fittings reveal the importance of liturgical and reverential continuity to a local community enduring a massive upheaval to the core of their religious identity. Surviving objects associated with these processes emerged as physical touchstones of communal and even familial memory for parishioners. Even though ecclesiastic and theological structures had been transformed by the Reformation, families still attended service in the same buildings and received the essential sacraments from the same fittings as their forebears. It could be argued that this level of practical continuity of religious experience provided just enough for most parishioners to abide the removal and defacement of prominent images which were often funded by the wealthiest among them.

Iconoclasm was central to the establishment of a 'revisionist memory', as the removal of certain images could eventually lead to an entire generation forgetting offensive icons and schemes. That being said, the defaced remains of various images were a constant reminder of the role these images played in England's religious heritage while perpetuating the memory in a negative light.

\section{Generational and Liturgical}

The case studies and statistical data suggest that continued liturgical use contributed to the survival, reuse, defacement, destruction or innovation of an artifact. The 1563 Thirty-nine Articles of Religion established the sacraments of Baptism and the Eucharist as having been ordained by Christ in scripture. As a result, baptismal fonts, font covers, and even rood screens were still necessary for Anglican worship conducted at parish churches. Fonts possess the highest rate of survival (.65 fonts per church), with over 205 fonts predating 1660. Of these, 193 are medieval survivals, and 12 are Reformation innovations. These finding can be attributed to the continued importance of the ritual, combined with the significant cost associated for a potential replacement fitting. At Castle Acre, the church retained its plain octagonal fifteenth-century font and repurposed an elaborate canopy cover from the neighboring Castle Acre Priory. The ingenuity of the engineering, along with the continued need to keep the baptismal water clean, resulted in a purposeful reallocation of a religious furnishing 
from a suppressed monastery to a still-necessary parish church. Other surviving fonts, like St Gregory's Church at Norwich with its carved angels and grotesques representing the triumph of good over evil, is a reminder that the laity most likely still viewed baptism as more than a mere symbolic initiation in the Christian faith.

Fittings adorned with iconography promoting Catholic liturgy, such as the East Anglian seven sacrament fonts, proved to be an unacceptable form of visual representation; even though, the fitting itself was still necessary. The four sample groups examined possess 9 of the 30 cases of this style of font found in the entire county (Pevsner \& Wilson, 1999, p. 64); with nearly all showing varying degrees of iconoclasm. The seven sacrament font found at Burgh-next-Aylsham, with the Mass of St. Gregory chosen as the eight panel, offers a glimpse into the struggles reformers endured in promoting a new theology in the face of liturgical continuity. Images like this provided the wrong messages to the laity in regards to the new meaning behind sacrament, specifically, communion in this case. While the very success of the Church of England may have lain in its ability to think Protestant, while looking Catholic, the nuances could easily have been lost on a parishioner from a remote rural village.

Cases such as the seven sacrament font at Sloley, are a reminder of the limitations imposed upon this study by the extensive Victorian restorations. While the interior of the Sloley church retains a modest post-Reformation aesthetic favored by Puritans, a close analysis of the cuts in the stone suggests a freshness that may have been a result of the font being restored at some point in the nineteenth century. The notion of images representing a series of Catholic rituals is not unusual, as the Oxford Movement held ideals which favored and evolved into modern Anglo-Catholicism as it attempted to orientate the roots of Anglicanism away from its Protestant origin (Yates, 2012, p. 249). The circumstances for the church's pre-Tractarian interior designs aside, it is a reasonable assumption that the panels were indeed damaged at some point during the Reformation before being skillfully restored (Derrick, 1935, p. 90).

Fittings, such as the medieval font at Sloley, are a reminder of the difficulties that plague an analysis of ecclesiastic materials. The Victorian desire to restore a Gothic veneer to the buildings and a Catholic facade to Anglicanism continues to make it a 
challenging enterprise to decipher surviving evidence in a sixteenth and seventeenthcentury context. Fortunately, in the case of Sloley, evidential threads consistent with the wider context are present upon a closer investigation.

Other fittings, like the seven sacrament fonts belonging to St. Mary in the Marsh in Norwich, suggest that a fitting was intimately tied to community identity. After the parishioners lost their church and were installed at Norwich Cathedral, this heavily mutilated font moved with them; this no doubt offered a visual touchstone of their heritage and eased the transition. Generations later, the congregants could boast that baptism were still administered from the same stone bowl, if not from the same building.

The continuance of Baptism and the Eucharist through the Reformation ensured that the more durable fittings, like stone fonts, were needed; while rood screens could be modified to serve as communion partitions by the removal of the upper open tracery. Font covers, which were often constructed of wood, did not have the longevity of the fonts themselves, resulting in the need to be replaced. At Norwich, two Jacobean era wooden covers at St. Gregory's and St. Andrew's were constructed to ensure that baptism water remained clean. While the former features carvings of Christ, the Apostles and Noah's family, the latter does not feature ornamentation of any kind. Within the context of the period, these two covers represent the religious divide over the aesthetic of Anglicanism; however, the need for the sacrament itself, in some form, does not appear to be in question.

Throughout the Reformation, the continued need to partition space for the efficient administration of communion required chancel screens; albeit, in a modified form to avoid the illusion of clerical sacrality or acknowledgment of transubstantiation. At Attleborough, the longest screen in East Anglia was repurposed to serve the Eucharistic needs of the communicants, while providing an impressive canvas to promote passages from Scripture and Anglican hierarchy. These liturgical demands were also met through the 15 cases of communion rails found in the rural sample groups, which confirm the continued importance of this sacrament. 
The fierce debate over the placement of the communion table was an extension of this argument, with some wanting it within the nave amongst the congregants and other promoting its medieval placement in the east end of the church where the altar had been located, behind the screen or rails. After Laud enforced the eastern placement in 1637 (Chipman, 2013, p. 107), the true consequences for allowing the sacrament to survive with any degree of formality were made painful clear to those who continued to protest that the state church was only partially reformed (Spraggon, 2003, p. 98).

The generational and liturgical continuity, seen in regards to baptism and communion, were simultaneously the sources of the Reformation's success, in allowing the parishes generations to ease into the new order of things, and the impetus for the later conflict over the proper mode of worship. This gradual march forward enabled the ordinary people the opportunity to live out their days conformed and quiet, while still internally experiencing their faith within a Catholic context.

\section{Reverential}

The failure to establish a truly Protestant church, in appearance and not just thought, resulted in the endurance of many liturgical practices tied to Roman Catholicism. While this may have provided to the necessary ingredient for the effective deCatholicization of the nation, it simultaneously offered a mixed message which enabled parishioners to embrace the new church without necessarily altering their perception of religion. The church fittings found across Norfolk reveal that material infrastructure required to conduct many of these practices, such as baptism and communion, were still quite essential.

Baptismal fonts, which are predominantly medieval innovations, possess the highest rate of survival; with an average of $60 \%$ across all four samples and an even greater rate of $68 \%$ while only looking at the rural groups. 


\section{Chapter VIII: Conclusion}

\section{In Closing}

This thesis aimed to provide a thorough examination of the impact of the English Reformation through a detailed analysis of medieval and early modern church fittings surviving at parish churches located throughout the county of Norfolk in England. By utilizing an archaeological approach along with the written record, a deeper and more nuanced understanding of public worship reveals the theological imperatives of the reformers and conformers.

The previous chapter discussed the five research questions in detail, demonstrating the Reformation was facilitated by physical touchstones that provided a bridge between Catholicism and Protestantism. Fittings which retained their liturgical usefulness in accordance with the new religious doctrines, shaped by a sola scriptura agenda, survived the demolition of the material culture, which remains a hallmark of the period. As for the artistic representation found on these fittings, and elsewhere throughout a church, we observed a selective iconoclasm where images were spared or defaced based on subject matter as opposed to indiscriminate vandalism. Once again, the evidence reinforced the notion of the Bible being the absolute center of a religious experience, serving as both the foundation of the new Anglican church and a raft for legacy converts.

The importance of access to a Bible translated into the vernacular coincided with a rise in literacy rates across the country, while the narratives and messages found within were propagated through preaching and the deliberate tolerance for medieval iconography derived from Scripture. The flame of Roman Catholicism was ultimately extinguished through generational attrition, as such visual continuity enabled an entire generation to continue their religious experience in a traditional context in spite of the alteration to liturgy and comprehensive transformation of doctrine.

The central inquiry of this study was to explore how and why England ceased to be a Catholic nation in the sixteenth century, beyond the mere machinations of the ruling 
elite. How could a popular and vibrant Church be purged from society with marginal reprisals and eradicated from the hearts of its people within a few generations? What was this 'Reformation' and was it a success?

Chapter III addressed the historiography of the Reformation, laying out the traditional, revisionist and post-revisionist approaches utilized in the examinations of the period. The traditional paradigm argued that the Reformation was an orderly march towards modernity engineered by the Tudor states and fueled by a grassroots malcontent for a corrupt Roman Catholic Church. This position was supplanted by a more rigorous analysis of parish documents, which revealed the popularity and centrality that Catholicism still held with most citizens on the eve of Reformation. This revelation flipped the traditional script, as the Tudors could now be deemed as tyrants who foisted unwelcome religious policies upon their country to satisfy their own agenda. As we observed, the disparate, and occasionally scattershot, approach to religious policy allowed the Reformation to unfold gradually, in stages, which prevented any widespread uprising commensurate with the importance what was at stake to a parishioner who believed their souls were in danger without the Catholic sacraments.

This study aimed to expand upon the use of the material record in answering these questions, which revealed that the fittings and images which survived were all validated by the Bible, which appeased the reformers, while maintaining a liturgical and visual continuity for everyone else. The results were not necessarily the successful establishment of religious uniformity, but a triumphant overthrow of Roman Catholicism, in body if not in mind.

Chapter IV presented a series of case studies for medieval church fittings, including fonts, screens, paintings and sculptures, which survived the Reformation with their artistic depictions intact. In addition to the survival of fittings being attributed to liturgical continuity, images depicting figures and narratives from the Bible endured unmolested at a noticeable rate. Chapter $\mathbf{V}$ continued by looking at the remaining medieval survivals that retained signs of iconoclasm and vandalism, with special attention paid to those fittings that were only partially and selectively defaced. The data and case studies for this section revealed a pronounced bias against images 
promoting either Catholic doctrine or figures from extrabiblical history; this suggests a fairly sophisticated comprehension of Protestant belief and the centrality of Scripture.

The data and case studies presented in Chapter VI looked at new fittings and decorative motifs utilized following the start of the Reformation, in 1534, until the 1660 Restoration. The extended chronological boundaries allowed a broader analysis, which saw the Bible, and even passages from its text, become a prominent form of decoration for the remainder of the sixteenth century. The following century ushered in conflict over the nature of church interior, as Puritans promoted a more austere approach to decor, while High Church Anglican pushed the boundaries of ceremonial ornamentation within a Scripture context. Also, a pronounced increase in the implementation of secular commemorations, ranging from local gentry to the Crown, was observed, suggesting that the void left behind by Roman Catholicism needed more than the Church of England to fill.

The Holy Bible was the bridge between two religious worlds, which can be attributed to the success of the English Reformation in regards to its break with the Catholic Church. As vernacular editions became available to an increasingly literate population, the Bible served a doctrinal foundation for reformers, while providing a template for which elements of Catholicism were deemed acceptable. This criterion eased the transition for a generation, as liturgical continuity and selective iconoclasm forged a new physical religious environment that retained enough elements to satisfy traditionalists.

The reformers were appeased into conformity, as Protestant doctrine redefined the purpose of the surviving rituals and iconography, with the latter emerging as a visual extension of the campaign to promote the primacy of Scripture. This selective iconoclasm edited and censored the religious imagery with theological purpose, as images of Christ and the Apostles fared much better than those of St. Christopher, the Virgin Mary, or the seven sacraments. This, along with preaching, helped bridge the chasm between a literate and illiterate laity and reoriented religious expression in a distinctly scriptural direction. 


\section{Future Research}

Future research can expand upon the foundation established in this work in several ways. First, the scope of the material record can be expanded to include additional surviving church fittings, such as stained glass windows and benches. This could also expand upon previous research conducted in Norfolk to include funerary monuments in order to provide greater context.

Second, church exteriors at every parish assessed in this study should be examined as a logical extension of the assessment of interiors. As the Reformation swept away many of the rituals and events which would be hosted in the churchyard, its role in commemoration remained vibrant. Furthermore, as expressed by Matthew Wren, bishop of Norwich during the Laudian innovations, these church exteriors were akin to sleeping quarters, where those buried were awaiting to be awoken along with other members of their community through bodily resurrection (Cressy, 1997, p. 385). This notion connects to memory theory, as all of these deceased parishioners had received their religious initiations within the same vicinity of their burial. This connection between church interiors and exteriors offers an opportunity to examine an unbroken continuity by linking life and death with the ceremonies of baptism and burial (Cressy, 1997, p. 386).

Third, the impact of the Reformation on domestic devotion across the county could be examined and cross-referenced with the parochial finding discussed in this study. It would be compelling to discover a correlation between parishes who endured greater censorships exhibiting a higher rate of private devotional artefacts. Finally, gender identity in relation to the Reformation is a rich and extensive area that warrant further investigation, including not only the anti-Marian iconoclasm examined, but the sociopolitical ramifications of two female monarchs during the period.

Outside of Norfolk, the methods employed here could be utilized at alternative counties, such as Suffolk, Leicestershire, and York. These finds could potentially reinforce the arguments made in regards to acceptability and continuity of the visual and liturgical function of church fittings. Furthermore, it could reveal either regional disparity or some degree of commonality in regards to how the Reformation unfolded. 
It is the opinion of the author that the 1660 Restoration does not represent an ideal chronological boundary for an analysis of an extended Reformation. Instead, the 1688 overthrow of James II is a more appropriate conclusion to such a study, as the religious element to the revolution, with the spectre of Roman Catholicism being restored by predilection of a monarch would offer better historical symmetry with the actions of Henry VIII that inaugurated the period.

The English Reformation brought far more than mere political drama and intrigue, as the very foundation of a modern western society was inadvertently being established with the mandates of state and church becoming obscured. While some historians have argued that the ramifications were marginal, as England remained a Christian nation (Haigh, 1993, p. 295), this view fails to see the central role religion played in identity, as the imposition of even nuanced alterations could dramatically transform societal expectations for authority within a generation.

Henry's dissolution of the monasteries had long-term ramifications in widening the scope of secular authority, as the burden of welfare fell to the state as the lands passed into private hands. While the suppression of the monasteries, guilds, and chantries undermined people's expectation of religion, the Edwardian foray into the parish churches was the closest equivalent to entering peoples' very homes. Yet, widespread compliance, apathy or toothless grumbling is all the regime received for this effrontery. While this does not suggest either acceptance or even understanding, of what it meant to be good Protestants, it does demonstrate a loss of any comprehension of what it meant to be a good Catholic. The subsequent brutality of Mary provided reformers with a propaganda narrative which allowed Elizabeth to promote a via media approach to religious conformity, such as the visual and liturgical continuity of church fittings, that galvanized the success of the Reformation.

The following century demonstrated the consequences of many of these gradual compromises, as distinct religious factions emerged, which exacerbated the complications of sovereignty, finances, religion, foreign policy and local control. An analysis of these tumultuous days are a natural extension of an examination of the 
traditional chronological confines of the Reformation, as the reforms did not cease as the specter of Roman Catholicism still looms; albeit, more and more in the distance.

The abolition of Roman Catholicism empowered secular authority at every level of society, as the void left behind by the Church needed to be filled. While this contributed to the success of the Reformation, it further marginalized the perception of authority as Englishmen were becoming more accustomed to challenging abuses of power when a stronger alternative was presented. This was the case throughout the Wars of the Roses and continued into the Tudor dynasty as yet another bulwark of authority, the Church, was dismantled by rival claimant. The religious legislation of the period bolstered the Parliament as a junior partner with the Crown in sovereignty, which no doubt contributed to the extraordinary struggle between the two in the seventeenth century.

Ultimately, England was a nation of Christians in 1534 and continued to be so in 1660 and beyond. People still went to church, prayed, received moral instructions and returned to their lives as if what we call 'the English Reformation' had never transpired (Haigh, 1993, p. 295). Yet, the relationships between man and God, subject and king, citizen and government, England and Europe, and even life and death were fundamentally altered forever. As the Reformation is woven into the broader tapestry of English history, nearly all pathways to modernity converge throughout this period and continue to unfold to this day. Some Reformation indeed. 


\section{Bibliography}

Alcock, S. E. \& Van Dyke, R. M., 2003. Archaeologies of Memory: An Introduction. In: S. E. Alcock \& R. M. Van Dyke, eds. Archaeologies of Memory. Malden: Blackwell, p. 1-14.

Alexander, J. J. G., 1994. The Pulpit with the Four Doctors at St James's Castle Acre, Norfolk. In: England in the fifteenth century: Proceedings of the 1992 Harlaxton Symposium. Stamford: Paul Watkins, pp. 198-206.

Alston, G. C., 1912. Rood. In The Catholic Encyclopedia. [Online] Available at: http://www.newadvent.org/cathen/13181a.htm [Accessed 1003 2013]. Annual Congress at Great Yarmouth and Norwich, 1880. Proceedings of the Congress of Greay Yarmouth. In: Journal of the British Archaeological Association. London: British Archaeological Association.

Anon., 1781. History and antiquities of the county of Norfolk. Norwich: M. Booth. Anon., 1781. The History And Antiquities Of The County Of Norfolk: Clavering, Depwade, Diss And Earsham. Norwich: M. Booth.

Anon., 1781. The History and Antiquities of the County of Norfolk: Freebridge Lynn, Freebridge Marshland, and Gallow. London: J. Crouse,.

Anon., 1855. The Guide to Norwich and Its Neighbourhood, by a Resident. London: Jarrold and Sons.

Anonymous, 1768. The History Of The City And County Of Norwich: From The Earliest Accounts To The Present Time. Norwich: John Crouse.

Armstrong, M. J., 1781. History and antiquities of the county of Norfolk: The Hunreds of Clavering, Depwade, Diss and Earsham. Norwich: M. Booth.

Armstrong, M. J., 1781. History and antiquities of the county of Norfolk: The Hunreds of Smithdon, Taverham, Tustead, Walfham, and Wayland. Norwich: M. Booth. Astley, H. J. D., 1907. A Group of Norman Fonts in North-west Norfolk. In: Norfollk Archaeology. Norwich: Norfolk and Norwich Archaeological Society, pp. 97-124. Aston, M., 1984. Lollards and reformers : images and literacy in late medieval religion. London: Hambledon Press.

Aston, M., 1988. England's iconoclasts. Oxford: Oxford University Press. 
Aston, M., 1989. Iconoclasm in England. In: C. Davidson \& A. E. Nichols, eds. Iconoclasm vs. art and drama. Kalamazoo: Medieval Institute Publications, p. 47-91. Aston, M., 1993. Faith and fire : popular and unpopular religion, 1350-1600. London: Hambledon Press.

Aston, M., 1993. Faith and fire : popular and unpopular religion, 1350-1600. London: Hambledon Press.

Aston, M., 2003. Public Worship and Iconoclasm. In: D. Gaimster \& R. Gilchrist, eds. The Archaeology of Reformation, 1480-1580. Leeds: Maney Publishing, pp. 9-28.

Atherton, I., 2010. Cathedrals, Laudianism, and the British Churches. Historical Journal, 53(4), pp. 895-918.

Ayer, B., 2005. Urban Landscape. In: C. Rawcliffe \& R. Wilson, eds. Medieval Norwich. London: Hambledon Press, pp. 1-13.

Ball, A., 2003. Encyclopedia of Catholic devotions and practices., Ind: Our Sunday Visitor, 2003. Print.. Huntington(IN): Our Sunday Visitor.

Barasch, M., 1997. The Language of Art: Studies in Interpretation. New York: NYU Press.

Barratt, A., 1991. The Herald of God's Loving-Kindness. Kalamazoo: Cistercian. Barratt, A., 2008. No such sitting: Julian tropes the Trinity. In: L. H. McAvoy, ed. $A$ Companion to Julian of Norwich. Woodbridge: D.S.Brewer.

Bayne, A. D., 1869. A Comprehensive History of Norwich. London: Jarrold \& Sons. Beloe, E. M., 1899. Our Borough: Our Churches: King's Lynn, Norfolk. Cambridge: MacMillan.

Beloe, E. M., 1926. Extracts from the chapel warden's accounts : of St. Nicholas' Chapel, King's Lynn, from the year 1616 to the date of the Restoration of His most sacred Majesty King Charles the Second. s.1.:s.n.

Benton, J. R., 1997. Holy Terrors: Gargoyles on Medieval Buildings. New York: Abbeville Press.

Berry, W., 1828. Encyclopaedia heraldica; or, Complete dictionary of heraldry. London: Sherwood, Gilbert and Piper.

Bindoff, S. T., 1982. The House of Commons: 1509-1558. London: Secker \& Warburg.

Bjorklund, N. B., 2003. "A Godly Wyfe Is an Helper": Matthew Parker and the Defense of Clerical Marriage. The Sixteenth Century Journal, 34(2), pp. 347-365. 
Blatchly, J., 2001. In search of bells: iconcolasm in Norfolk, 1644 . In: T. Cooper, ed. The journal of William Dowsing : iconoclasm in East Anglia during the English Civil War. Woodbridge: The Ecclesiological Society with Boydell, pp. 107-22.

Block, E. \& Varty, K., 2000. Choir-Stall Carvings of Reynard and Other Foxes. In: E. Block, ed. Reynard the Fox: Cultural Metamorphoses and Social Engagement in the Beast Epic from the Middle Ages to the Present. Oxford: Berghahn Books, pp. 125-162. Blomefield, F., 1805. An Essay Towards A Topographical History of the County of Norfolk. London: W Miller.

Blomefield, F., 1806. An Essay Towards A Topographical History of the County of Norfolk. London: W Miller.

Blomefield, F., 1807. An Essay Towards A Topographical History of the County of Norfolk. London: W Miller.

Blomefield, F., 1808. An Essay Towards A Topographical History of the County of Norfolk. London: W Miller.

Blomefield, F., 1809. An Essay Towards A Topographical History of the County of Norfolk. London: W Miller.

Blomefield, F., 1810. An Essay Towards A Topographical History of the County of Norfolk. London: W Miller.

Bloom, J. H., 1843. Notices, Historical and Antiquarian of the Castle and Priory at Castleacre, in the County of Norfolk. London: Pelham Richardson.

Blyth, G. K., 1842. The Norwich Guide and Directory: Being an Historical and Topographical Description of the City and Its Hamlets. Norwich: R. Hastings,. Bodleian Library, 1860. Catalogus codicum manuscriptorum Bibliothecae Bodleianae. Oxford: Bodleian Library.

Bond, F., 1908. Fonts and font covers. London: Oxford University Press.

Bond, F., 1908. Screens and Galleries in English Churches. Oxford: Oxford University Press.

Bonner, E., 1555. A profitable and necessarye doctrine: with certayne homelyes adioyned thervnto. London: Poules Churchyarde, at the sygne of the Holy Ghost, by Ihon Cawoode.

Bray, G. L. ed., 1994. Documents of the English Reformation 1526-1701. Cambridge: James Clarke \& Co. 
Bremer, F. J. \& Webster, T. eds., 2006. Puritans and Puritanism in Europe and America : a comprehensive encyclopedia. Santa Barbara: ABC-CLIO.

Brigden, S., 2001. New worlds, lost worlds : the rule of the Tudors, 1485-1603. New York: Viking.

British Archaeological Association, 1858. Fourteenth Annual Meeting, Norwich, 1857:

Proceedings of the Congress. Journal of the British Archaeological Association, Volume 14, pp. 63-87, 145-176.

Britton, J., 1816. The history and antiquities of the see and cathedral church of Norwich. London: Longman.

Brown, C. F., 1903. A Study of the English Grammar Schools Before the Reformation. Cambridge(MA): Harvard University.

Browne, J., 1877. History of Congregationalism and Memorials of the Churches in Norfolk and Suffolk. London: Jarrold and Sons.

Browne, P., 1814. The history of Norwich: from the earliest records to the present time. Norwich: R. Chipperfield.

Bruce, J., ed., 1865. Calendar and State Papers, Domestic Series, of the Reign of Charles I. 1635. London: Longman, Green, Longman, Roberts \& Green.

Bryant, T. H., 1898. Norfolk Churches: Hundred of North Greenhoe. Norwich: Norwich Mercury Office,.

Bryant, T. H., 1914. The churches of Norfolk: Hundred of Brothercross. Norwich: Norwich Mercury Co..

Buchanan, G. \& Maitland, T., 1689. De jure regni apud Scotos, or, A dialogue concerning the due priviledge of government in the kingdom of Scotland betwixt George Buchanan and Thomas Maitland. London: Richard Baldwin.

Bucholz, R. \& Key, N., 2004. Early modern England, 1485-1714 : a narrative history. Malden(MA): Blackwell .

Bush, D., 1968. The Rennaissance and English Humanism. Toronto: University of Toronto.

Calkins, R. G., 1983. Illuminated Books of the Middle Age. New York: Cornell University Press.

Calthorpe, H., 1886. In: L. Stephen, ed. Dictionary of National Biography. London: Smith, Elder \& Co. 
Capp, B., 2012. England's Culture Wars: Puritan Reformation and its Enemies in the Interregnum, 1649-1660. Oxford: Oxford University Press.

Cartier, E., ed., 1865. The Life of Beato Angelico Da Fiesole. London: John Phillip. Catholic Church, 2000. Catechism of the Catholic Church. 2nd ed. Vaticana: Libreria Editrice.

Cattermole, P. \& Cotton, S., 1981-83. Medieval Parish Church Building in Norfolk. In: Norfolk archaeology; or, Miscellaneous tracts relating to the county of Norfolk. s.1.:s.n., pp. 235-79.

Chambers, J., 1829. A General History of the County of Norfolk: Intended to Convey All the Information of a Norfolk Tour, with the More Extended Details of Antiquarian, Statistical, Pictorial, Architectural, and Miscellaneous Information; Including Biographical Notices, Original and Selected. Norwich: John Stacy.

Chapman, J., 2000. Fragmentation in archaeology: People, places, and broken objects in the prehistory of south-eastern Europe. London: Routledge.

Chaucer, G., 1915. Chaucer's Canterbury Tales: The Nun's Priest's Tale. London: MacMillan \& Co.

Chipman, S., 2013. Religious space in Reformation England : contesting the past. London: Pickering \& Chatto.

Church of England, 1825. The Book of common prayer and administration of the sacraments \& other rites \& ceremonies of the Church according to the use of the United Church of England and Ireland: together with the Psalter or Psalms of David, pointed as they are to be sung or said in the churches, and the form and manner of making, ordaining, and consecrating of bishops, priests, and deacons.. 3rd ed. Oxford: Baxter for Parker and Rivington.

Collier, M., 1904. Saint Christopher and Some Representations of him in English churches. Journal of the British Archaeological Association, Volume 10, pp. 130-145. Colling, J. K., 1851. An Attempt to Eludicate the Principles of Medieval Coloured Decoration. The Civil Engineer and Architect's Journal, Volume 14, pp. 277-280. Collins, A., 1741. The English baronetage : containing a genealogical and historical account of all the English baronets, now existing: their descents, marriages, and issues; memorable actions, both in war, and peace; religious and charitable donations. London: Thomas Wotton. 
Collins, A., 1914. Symbolism of animals and birds represented in English church architecture. New York: McBride, Nast and Co.

Collinson, P., 1982. The Religion of Protestants: The Church in English Society, 15591625. Oxford: Oxford University Press.

Collinson, P., 2007. Pulling the Strings. In: J. E. Archer, E. Goldring \& S. Knight, eds. The Progresses, Pageants, and Entertainments of Queen Elizabeth I. Oxford: Oxford University Press, pp. 122-141.

Combe, T., 1844. Illustrations of baptismal fonts. London: John Van Voorst.

Cooper, L. H., Denny-Brown, A. \& Edsall, M. A. eds., 2014. The Arma Christi in Medieval and Early Modern Material Culture: With a Critical Edition of 'O Vernicle'. Burlington(VT): Ashgate Publishing Company.

Cooper, T., ed., 2001. The Journal of William Dowsing: Iconoclasm in East Anglia during the English Civil War. Woodbridge: Boydell Press.

Cooper, T., 2013. Wise as Serpents: The form and setting of public workship at Little Gidding in the 1630s. In: N. Mears \& A. Ryrie, eds. Worship and the Parish Church in Early Modern Britain. Farnham: Ashgate, p. 197-220.

Cotman, J. S., 1838. Engravings of Sepulchral Brasses in Norfolk Tending to Illustrate the Ercclesiastical, Military, and Civil Costume as Well as to Preserve Memorials of Ancient Families in that County. London: Henry G. Bohn.

Cotton, S., 1987. Medieval Roodscreens in Norfolk their construction and painting dates. In: Norfolk Archaeology. Norwich: Norfolk \& Norwich Archaeological Societ, pp. 44-54.

Cox, J. C., 1915. Pulpits, lecterns, and organs in English churches. London: Oxford University Press.

Cressy, D., 1997. Birth, marriage, and death : ritual, religion, and the life-cycle in Tudor and Stuart England. Oxford: Oxford University Press.

Curran, S., 2011. The English Friend: A Life of William De La Pole, First Duke of Suffolk (1396-1450). Norwich: Lasse Pres.

Daggett, J. \& Sheffield, A. D., 1894. A Sketch of the History of Attleborough: From Its Settlement to the Division. Boston: Press of Samuel Usher.

Dasent, J. R. ed., 1892. Acts of the Privy Council of England Volume 4, 1552-1554.

London: Her Majesty's Stationery Office. 
Dasent, J. R. ed., 1895. Acts of the Privy Council of England 1578-1580. London: Her Majesty's Stationery Office.

Davis, N., ed., 1958. Paston Letters. Oxford: Clarenden Press.

Delderfield, E., 1966. A Guide to Church Furniture. Newton Abbot: David \& Charles. Derrick, F., 1935. Tales told in church stones; symbolism and legend in medieval architecture and handicrafts. London: Lutterworth Press.

DeWald, E. \& Wilde, J., 1932. The Illustrations of the Utrecht psalter. London: Oxford University Press.

Dickens, A. G., 1964. The English Reformation. New York: Schocken Books.

Ditchfield, P. H., 1902. The cathedrals of Great Britain, their history and architecture. London: J.M. Dent.

Dodds, M. H. \& Dodds, R., 1915. The pilgrimage of grace, 1536-1537, and the Exeter conspiracy, 1538. Cambridge: Cambridge University Press.

Doelman, J., 2000. King James I and the Religious Culture of England. Woodbridge: D.S.Brewer.

Duffy, E., 1992. The Stripping of the Altars: Traditional Religion in England, 14001580. New Haven(CT): Yale University Press.

Duffy, E., 2001. The voices of Morebath : reformation and rebellion in an English village. New Haven: Yale University Press.

Duffy, E., 2004. The Disenchantment of Space: Salle Church and the Reformation. In: J. D. Tracy \& M. Ragnow, eds. Religion and the Early Modern State: Views from China, Russia, and the West. New York: Cambridge University Press, pp. 324-348. Duffy, E., 2009. Fires of Faith: Catholic England under Mary Tudor. New Haven: Yale University Press.

Duffy, E., 2012. Saints, Sacrilege and Sedition: Religion and Conflict in the Tudor Reformations. London: Bloomsbury Academic .

Durant, W., 1957. The Reformation: The Story of Civilization. New York: Simon \& Shuster.

Eire, C. M., 2016. Reformations : the early modern world, 1450-1650. New Haven: Yale University Press.

Elkins, S., 1997. Gertrude the Great and the Virgin Mary. Church History, 66(4), p. 720-734. 
Ellicott, C. J. ed., 1987. A New Testament commentary for English readers. London: Cassel and Company.

Elton, G., 1953. The Tudor Revolution in Government. Cambridge: Cambridge University Press.

Elton, G., 1972. Policy and police: the enforcement of the Reformation in the age of Thomas Cromwell. London: Cambridge University Press.

Elton, G., 1977. Reform and Reformation: England 1509-1558. London: Arnold.

Farrow, M. A. ed., 1943. Index of wills proved in the Consistory Court of Norwich and now preserved in the District Probate Registry at Norwich, 1370-1550, and wills among the Norwich enrolled deeds, 1298-1508,. Norwich: Norfolk Record Society. Faul, D., 1994. SocietyThe Battle of the Dons: Recent Historiography of the English Reformation. Seanchas Ardmhacha: Journal of the Armagh Diocesan Historical Society, Vol. 16, No. 1 (1994),pp. , 16(1), pp. 276-288.

Fincham, K. \& Tyacke, N., 2007. Altars Restored: The Changing Face of English Religious Worship, 1547-c.1700. Oxford: Oxford University Press.

Finch, J., 2000. Church Monuments in Norfolk before 1850. Oxford: British Archaeological Reports.

Finch, J., 2003. A Reformation of meaning : commemoration and remembering the dead in the parish church, 1450-1640. In: D. Gaimster \& R. Gilchrist, eds. The Archaeology of Reformation, 1480-1580. Leeds: Maney Publishing, pp. 437-449. Finch, J., 2004. The Churches. In: C. Rawcliffe \& R. Wilson, eds. Medieval Norwich. London and New York: Hambledon and London, pp. 49-72.

Finnegan, M. J., 1991. The Women of Helfta: Scholars and Mystics. Athens: University of Georgia Press.

Firth, C. H. \& Rait, R. S. eds., n.d. May 1644: An Ordinance for the further demolishing of Monuments of Idolatry and Superstition. In: Acts and Ordinances of the Interregnum, 1642-1660. London: His Majesty's Stationery Office, pp. 425-426.

Foxe, J., 2013. Fox's Book of Martyrs. Lanham: Start Publishing LLC.

Freeman, E. A., 1895. Old-English history. 2nd ed. London: Macmillan.

Frere, W., ed., 2016. Articles to be enquired in the visitation in the first year of the reign of our most dread sovereign Lady Elizabeth, by the grace of God, of England, France, and Ireland, Queen, defender of the faith, \&c. Anno 1559.. In: Visitation Articles and Injunctions, Vol. 3: 1559-1575 . London: Forgotten Books . 
Frere, W. H., 1904. A History of the English Church: The English church in the reigns of Elizabeth and James I (1558-1625). London: Macmillan.

Gaimster, D., 2003. Pots, prints and Protestantism : changing mentalities in the urban domestic sphere, c.1480-1580. In: D. Gaimster \& R. Gilchrist, eds. The Archaeology of Reformation, 1480-1580 . Leeds: Maney Publishing, p. 122-144.

Gaimster, D. \& Gilchrist, R., 2003. Introduction. In: D. Gaimster \& R. Gilchrist, eds. The Archaeology of Reformation, 1480-1580. Leeds: Maney Publishing, pp. 1-8. Gairdner, J., ed., 1890. Letters and Papers, Foreign and Domestic, Henry VIII, January-May 1537. London: Her Majesty's Stationery Office.

Gayk, S., 2014. Early Modern Afterlives of the Arma Christi. In: L. H. Cooper \& A. Denny-Brown, eds. The Arma Christi in Medieval and Early Modern Material Culture. New Edition ed. Abingdon: Routledge, pp. 273-308.

Gee, H. \& Hardy, W. J., 1896. Documents illustrative of English church history. London: MacMillian and Co..

Gilchrist, R., 2003. 'Dust to dust' : revealing the Reformation dead. In: D. Gaimster \& R. Gilchrist, eds. The Archaeology of Reformation, 1480-1580. Leeds: Maney Publishing, pp. 399-414.

Gilchrist, R., 2005. Norwich Cathedral Close : the evolution of the English cathedral landscape. Woodbridge: Boydell.

Giles, K., 2003. Reforming corporate charity : guilds and fraternities in pre- and postReformation York . In: D. Gaimster \& R. Gilchrist, eds. The Archaeology of Reformation, 1480-1580. Leeds: Maney Publishing, pp. 325-340.

Giles, K., 2007. Seeing and Believing: Visuality and Space in Pre-Modern England. World Archaeology, 39(1), pp. 105-121.

Goldman, R., 1847. The Account of Robert Goldman, Chamberlain of the City of Norwich, which money expended in mustering and traisning soliders, 1588. In: Norfolk Archaeology. Norwich: Norfolk and Norwich Archaeological Society, pp. 5-16. Graves, C. P., 2008. From an archaeology of iconoclasm to an anthropology of the body : images, punishment and personhood in England, 1500-1660. Current anthropology, Volume 1, pp. 35-57.

Graves, P. C., 2007. Sensing and Believing: Exploring Worlds of Difference in PreModern England: AContribution to the Debate Opened by Kate Giles. World Archaeology,, 39(4), pp. 515-531. 
Great Britain. Record Commission, 1810-1834. Valor ecclesiasticus temp. Henr. VIII. Auctoritate regia institutus.. Lodnon: Record Commission.

Gregory, J., 1998. The Making of a Protestant Nation: 'Success' and 'Failure' in England's Long Reformation. In: N. Tyacke, ed. England's Long Reformation, 15001800. London: UCL Press, pp. 307-333.

Groves, N., 2010. The Medieval Churches of the City of Norwich. Norwich: Norwich Heritage Economic and Regeneration Trust.

Gunthrie, D., 1945. A History Of Medicine. London: Thomas Nelson and Sons. Haigh, C., 1993. English Reformations: Religion, Politics, and Society under the Tudors. Oxford: Clarendon Press.

Haigh, C., 2001. Success and Failure in the English Reformation. Past and Present, Volume 173, pp. 28-49.

Hall, J. \& Pratt, J., 1808. Works: Some Specialities In The Life Of Bishop Hall. Letter From The Tower. Bishop Hall's Hard Measure.. London: C. Whittinhham.

Hamilakis, Y., 1998. Eating the dead: Mortuary feasting and the politics of memory in the Aegean Bronze Age societies. In: K. Brannigan, ed. Cemetery and society in the Aegean Bronze Age. Sheffield: Sheffield Academic Press, p. 115-31.

Hamilton, W. D. \& Lomas, S. C., 1897. Calendar of State Papers Domestic: Charles I, 1625-49. London: Her Majesty's Stationery Office.

Hart, R., 1872. Illustrations of the Rood-screen at Fritton. Norwich: Society by Miller and Leavins.

Heal, F., 2017. Art and Iconoclasm. In: A. Milton, ed. The Oxford History of Anglicanism, Volume 1: Reformation and Identity c.1520-1662. Oxford: Oxford University Press, pp. 186-209.

Hedley, J. C., 1907. The Holy Eucharist. London: Longmans.

Hempnall Group of Parishes, n.d. Fritton - St Catherine. [Online]

Available at: http://www.hempnallgroup.co.uk/churches-and-church-life/our-

villages $8997 /$ fritton/

[Accessed 0509 2016].

Herbermann, C. G. ed., 1907. The Catholic encyclopedia; an international work of reference on the constitution, doctrine, discipline, and history of the Catholic Church. New York: Encyclopedia Press. 
Heywood, S., 1996. The Romanesque building. In: I. Atherton, ed. Norwich

Cathedral : church, city, and diocese, 1096-1996. London: Hambledon Press, pp. 73115.

Heywood, S., 2013. The Church of St Margaret Hardwick Civil parish of Shelton Norfolk, Norwich: s.n.

Hill, G. F., 1939. A History of North Burlingham Churches S. Andrew and S. Peter. Norwich: Roberts Printers.

Hindle, S., 2000. The State and Social Change in Early Modern England, 1550-1640. New York: Palgrave.

Holderness, J., 1994. Farming Regions 1500-1750. In: P. Wade-Martins \& J. Everett, eds. Historical Atlas of Norfolk. Hunstanton: s.n., pp. 102-103.

Hooker, R. \& Bayne, R., 1902. Of the Laws of Ecclesiastical Polity: The Fifth Book. New York: MacMillan.

Hooper, A., 2004. The Civil War. In: C. Rawcliffe \& R. Wilson, eds. Norwich since 1550. London: Hambledon Continuum, pp. 89-116.

Houlbrooke, R., 1998. Death, Religion, and the Family in England, 1480-1750.

Oxford: Clarendon Press.

Houlbrooke, R. \& McClendon, M., 2006. The Reformation. In: C. a. W. R. Rawcliffe, ed. Medieval Norwich. London: Hambledon Continuum, pp. 255-276.

Howard, F. E. \& Crossley, F. H., 1919. English Church Woodwork: A Study in Craftsmanship During the Mediaeval Period A.D. 1250-1550, Parts 1250-1550.

London: B.T. Batsford.

Howard, M., 2003. Recycling the monastic fabric : beyond the Act of Dissolution. In:

D. Gaimster \& R. Gilchrist, eds. The Archaeology of Reformation, 1480-1580. Leeds: Maney Publishing, pp. 221-34.

Hughes, P., 1953. The Reformation in England. London: Hollis \& Carter.

Huscroft, R., 2005. Ruling England, 1042-1217. New York: Pearson/Longman.

Hutchinson, R., 2003. Tombs of brass are spent : Reformation reuse of monumental brasses. In: D. Gaimster \& R. Gilchrist, eds. The Archaeology of Reformation, 14801580. Leeds: Maney Publishing, pp. 450-468.

Hutton, W. H., 1903. A History of the English Church: From the Accession of Charles I. to the Death of Anne (1625-1714). London: MacMillan \& Co.. 
James, E. B., 1896. Letters, archaeological and historical relating to the Isle of Wight. London: Henry Frowde.

James, M., 1917. Lives of St. Walstan. In: Norfolk Archaeology. Norwich: Norfolk \& Norwich Archaeological Society, p. 238-67.

James, M. R., 1930. Suffolk and Norfolk : a perambulation of the two counties with notices of their history and their ancient buildings. London: J.M. Dent and Sons. Jarrold and Sons, 1884. Jarrolds' Guide to Norwich. Norwich: Jarrold and Sons. Jensen, R. M., 2012. Baptismal imagery in early Christianity : ritual, visual, and theological dimensions. Grand Rapids(MI): Baker Academic.

Jessopp, A., 1888. Visitations of the diocese of Norwich, 1492-1532. Westminster: Council of the Camden Society.

Jessopp, A. \& James, M. R., 1896. The Life and Miracles of St William of Norwich by Thomas of Monmouth. Cambridge: Cambridge Universiry Press.

Jones, S., 2006. Discourses of identity in the interpretation of the past. In: T. Insoll, ed. The Archaeology of Identities: A Reader. London: Routledge, pp. 44-58.

Jurkowski, M., 2007. Lollardy and Social Status in East Anglia. Speculum, 82(1), pp. 120-152.

Jurkowski, M., 2007. Lollardy and Social Status in East Anglia. Speculum, 82(1), pp. $120-15$.

Kinch, A., 2008. Image, Ideology, and Form: The Middle English Three Dead Kings in Its Iconographic Context. The Chaucer Review, 43(1), pp. 48-81.

King, D., 2006. The Medieval Stained Glass of St Peter Mancroft, Norwich. Oxford: Oxford University Press.

King, D., 2013. Medieval Art in Norfolk and the Continent: An Overview. In: B. David \& R. Liddiard, eds. East Anglia and Its North Sea World in the Middle Ages.

Woodbridge: Boydell Press, pp. 82-119.

King, J. N., 2000. Milton and Religious Controversy Satire and Polemic in Paradise Lost. Cambridge: Cambridge University Press.

Kishlansky, M. A., 1986. Parliamentary Selection: Social and Political Choice in Early Modern England. Cambridge: Cambridge University Press.

Knott, S., 2005. St James, Castle Acre. [Online]

Available at: http://www.norfolkchurches.co.uk/castleacre/castleacre.htm

[Accessed 11 2013]. 
Knott, S., 2005. St Mary, South Creake. [Online]

Available at: http://www.norfolkchurches.co.uk/southcreake/southcreake.htm [Accessed 1105 2014].

Knowles, D., 1959. The religious orders in England. Cambridge: Cambridge University Press..

Koerner, J., 2002. The icon as iconoclash. In: B. Latour \& P. Weibel, eds. Iconoclash: Beyond the Image Wars in Science, Religion and Art. London: MIT Press, pp. 164-213. Koerner, J. L., 2004. The reformation of the image. Chicago: University of Chicago Press.

Kuehn, R., 2007. A Place for Baptism. Chicago: Liturgy Training Publications.

Kumar, K., 2015. The idea of Englishness : English culture, national identity and social thought. Farnham: Ashgate Publishing.

Ladick, J. R., 2011. Windows into the Soul: Contextual interpretation of church fittings in Norwich during the English Reformation, Leicester: University of Leicester.

Lanzi, F. \& Lanzi, G., 2004. Saints and Their Symbols: Recognizing Saints in Art and in Popular Images. Collegeville: Liturgical Press .

Le Strange, R., 1973. Monasteries of Norfolk. King's Lynn: Yates Publications.

Leclercq, H., 1910. Fourth Lateran Council (1215). In: The Catholic Encyclopedia. New York: Robert Appleton Company.

Lee, S., 1886. The Dictionary of National Biography. London: Macmillan.

Leone, M., 1988. The relationship between archaeological data and the documentary record. Historical Archaeology, 22(1), pp. 29-35.

Linley, K., 2016. 'Volpone' in Context: Biters Bitten and Fools Fooled. London: Anthem Press.

Litzenberger, C., 1997. The English Reformation and the Laity: Gloucestershire, 15401580. New York: Cambridge University Press.

Livingstone, E. A. ed., 2014. Dissolution of the Monasteries. In: The Concise Oxford Dictionary of the Christian Church. Oxford: Oxford University Press, p. 166.

Lucas, S., 2003. The Consolation of Tragedy: "A Mirror for Magistrates" and the Fall of the "Good Duke" of Somerset. Studies in Philology, 100(1), pp. 44-70.

Luders, A. et al. eds., 1810. The Statutes of the Realm: 1509-1545. London: Record Commission. 
Ludwig, A., 1966. Graven Images: New England Stonecarving and Its Symbols, 16501815. Middletown: Wesleyan University Press.

Mâle, É., 1973. The Gothic Image: Religious Art In France Of The Thirteenth Century. Reissue ed. New York: Perseus Books Group.

MacCulloch, D., 1986. Suffolk and the Tudors : politics and religion in an English county, 1500-1600. Oxford: Oxford University Press.

MacCulloch, D., 1990. The Later Reformation in England, 1547-1603. Houndsmill: Macmillan.

MacCulloch, D., 1991. The Myth of the English Reformation. Journal of British Studies, 30(1), pp. 1-19.

MacCulloch, D., 2005. Putting the English Reformation on the Map: The Prothero

Lecture. Transactions of the Royal Historical Society, Volume 15, pp. 75-95.

Mari, P., 2010. Architecture at the Service of Ideology: William Morris, the Anglican

Church and the Destruction, Restoration and Protection of Medieval Architecture in Victorian England, Montreal: University of Montreal.

Marks, R. \& Williamson, P., 2003. Gothic: Art for England: 1400-1547. London:

Victoria \& Albert Museum .

Marshall, P., 2002. Deceptive Appearences: Ghosts and Reformers in Elizabethan and Jacobean England. In: H. Parish \& W. Naphy, eds. Religion and Superstition in Reformation Europe. Manchester: Manchester University Press, pp. 188-208. Marshall, P., 2009. (Re)defining the English Reformation. Journal of British Studies, Volume 48, pp. 564-586.

McClendon, M., 1999. The Quiet Reformation: Magistrates and the Emergence of Protestantism in Tudor Norwich. Stanford: Stanford University Press.

McClendon, M. C., 1998. Religious toleration and the Reformation: Norwich magistrates in the sixteenth century. In: N. Tyacke, ed. England's long reformation, 1500-1800. London: UCL Press.

McCullough, P., 2017. 'Avant-Garde Conformity' in the 1590s. In: A. Milton, ed. The Oxford History of Anglicanism, Volume 1: Reformation and Identity c.1520-1662.

Oxford: Oxford Univerity Press, pp. 380-394.

McLeod, R. F., 1882. Massingham Parua Past and Present. London: Waterlow. Meskell, L., 2006. Archaeologies of identity. In: T. Insoll, ed. The Archaeology of Identities: A Reader. London: Routledge, pp. 23-44. 
Michael, E., 2003. John Wyclif on body and mind. Journal of the History of Ideas, 64(3), pp. 343- 360 .

Milner, M., 2011. The Senses and the English Reformation. Farnham: Ashgate Publishing.

Milton, A., 1995. Catholic and Reformed: The Roman and Protestant Churches in English Protestant Thought, 1600-1640. Cambridge: Cambridge University Press. Mitchell, J., 2000. Painting in East Anglia around 1500. In: J. Mitchell \& A. Martindale, eds. England and the Continent in the middle ages : studies in memory of Andrew Martindale : proceedings of the 1996 Harlaxton Symposium. Stamford: Shaun Tyas.

Moens, W. J. C., 1888. The Walloons and their church at Norwich. 1565-1832.

Lymington: Huguenot Society of London.

Monmouth, T. o., Jessopp, A. \& James, M. R., 1896. The life and miracles of St. William of Norwich. Cambridge: Cambridge University Press.

Moore, A., 1996. The Evidence for artistic contact between Norfolk and the Netherlands 1500-1800. In: J. Roding \& L. Voss, eds. The North Sea and culture (1550-1800) : proceedings of the international conference held at Leiden 21-22 April 1995. Hilversum: Verloren, pp. 355-377 .

Moorman, J. R., 1945. Church Life in England in the Thirteenth Century. Cambridge: Cambridge University Press.

Moreland, J., 2001. Archaeology and Text. Bristol: Bristol Classical Press.

Morrill, J., 2001. William Dowsing and the administration of iconoclasm in the Puritan revolution by . In: T. Cooper, ed. The Journal of William Dowsing Iconoclasm in East Anglia during the English Civil War. Woodbridge: The Ecclesiological Society with Boydell, pp. 1-28 .

Morris, R. K., 2003. Monastic architecture : destruction and reconstruction. In: D.

Gaimster \& R. Gilchrist, eds. The Archaeology of Reformation, 1480-1580. Leeds: Maney Publishing, p. 235-251.

Mortlock, D. P. \& Roberts, C. V., 2007. Guide to Norfolk Churches. 2nd ed. Cambridge: Lutterworth Press.

Muldoon, 1999. Empire and Order: The Concept of Empire, 800-1800. London: Palgrave Macmillan. 
Neal, D., 1822. The History of the Puritans, Or Protestant Nonconformists. London: William Baynes.

Newham, C. B., 2014. The Post-Reformation Wall Paintings Project. [Online] Available at: https://www.academia.edu

Nichols, A., 2002. The Early Art of Norfolk: A Subject List of Extant and Lost Art

Including Items Relevant to Early Drama. Kalamazoo(Mich): Medieval Institute

Publications/Western Michigan University .

Norfolk and Norwich Archaeological Society, 1846-. Norfolk Archaeology, Or,

Miscellaneous Tracts Relating to the Antiquities of the County of Norfolk. Norwich:

Norfolk and Norwich Archaeological Society.

Norfolk Historic Environment Service, 2007. MNF 1888. [Online]

Available at: http://www.heritage.norfolk.gov.uk/record-details?MNF1888

[Accessed 0602 2016].

Oakey, N., 2003. Fixtures or fittings? : can surviving pre-Reformation ecclesiastical material culture be used as a barometer of contemporary attitudes to the Reformation in England? . In: D. Gaimster \& R. Gilchrist, eds. The Archaeology of Reformation, 14801580. Leeds: Maney Publishing, pp. 58-72.

O'Neill, J. M., 1983. To believe in a vision. Rockville Centre(NY): Delmar .

Page, W. \& Doubleday, H. A. eds., 1906. Victorian History of the Counties of England: Norfolk. London: University of London.

Park, D. \& Howard, H., 1996. The Medieval Polychromy. In: I. Atherton, ed. Norwich Cathedral: church, city, and diocese, 1096-1996. London: Hambledon Continuum, pp. 379-409.

Paul, R., 1903. Notes on Archaeology and Kindred Subjects. In: J. R. Allen, ed. The Reliquary and Illustrated Archaeologist. London: Bemrose and Sons, pp. 51-65.

Pearson, C. H., 1867. History of England during the early and middle ages. London:

Bell \& Daldy.

Peirce, C. S., 1868. On a New List of Categories. Proceedings of the American Academy of Arts and Sciences, Volume 7, pp. 287-298.

Peltomaa, L. M., 2001. Image of the Virgin Mary in the Akathistos Hym. Leiden: Brill. Pennington, E. L., 1952. The Church of England and the Reformation. Eton: Savile Press. 
Perrin, W. G., 2012. British flags : their early history and their development at sea : with an account of the origin of the flag as a national device. Cambridge: Cambridge University Press.

Pestell, T., 2004. Landscapes of Monastic Foundation: The Establishment of Religious Houses in East Anglia, c.650-1200. Woodbridge: Boydell \& Brewer.

Pevsner, N. \& Wilson, B., 1997. The Buildings of England: Norfolk 1, Norwich and North East. 2nd ed. s.1.:Yale University Press.

Pevsner, N. \& Wilson, B., 1999. The Buildings of England: Norfolk 2, North West and South. 2nd ed. New Haven: Yale University Press.

Pinches, J. H. \& Pinches, R., 1974. The Royal Heraldry of England. Slough: Hollen Street Press.

Pollard, A. F., 1902. Henry VIII. London: Goupil \& Co.

Pollard, A. F., 1906. Thomas Cranmer and the English Reformation, 1489-1556. New

York: G. P. Putnam's Sons: Knickerbocker Press.

Prendergast, T. A., 2003. Chaucer's dead body : from corpse to corpus. New York: Routledge.

Preucel, R. W., 2007. Archaeological Semiotics. Hoboken: Wiley-Blackwell.

Pridgeon, E. E., 2008. Saint Christopher Wall Paintings in English and Welsh Churches c.1250-c.1500, Leicester: University of Leicester.

Ramsay, N., 1987. Artists, craftsmen and design in England, 1200-1400. In: J.

Alexander \& P. Binski, eds. Cover image Title Age of chivalry : art in Plantagenet England, 1200-1400. London: Weidenfeld \& Nicolson.

Rayson, G., 1864. Extracts from Parish Registers. No 4. Fritton, Norfolk. In: East Anglian, Or, Notes and Queries on Subjects Connected with the Counties of Suffolk, Cambridge, Essex and Norfolk. Tymms, Samuel ed. London: Whittaker and Co.

Reynolds, M., 2005. Godly Reformers and their Opponents in Early Modern England: Religion in Norwich, c.1560-1643. Woodbridge: Boydell Press.

Richmond, C., 2002. The Paston Family in the Fifteenth Century: Fastolf's Will. Cambridge: Cambridge University Press.

Ricketts, A. O. \& Ricketts, S., 2007. The English country house chapel : building a Protestant tradition. Reading: Spire Books.

Riddle, K. W., 1960. A Guide to the Church of St. Peter Mancroft. Norwich: Rev. K. Wilkinson Riddle. 
Ridyard, S. J., 2008. The Royal Saints of Anglo-Saxon England: A Study of West Saxon and East. Cambridge: Cambridge University Press.

Robertson, J. C., 1869. How shall we conform to the liturgy of the Church of England?. London: John Murray.

Robinson, B., 2011. The Legacy of the Reformation. [Online]

Available at: http://www.bbc.co.uk/history/british/tudors/reformation debate 01.shtml [Accessed 1004 2013].

Roffey, S., 2003. Deconstructing a symbolic world : the Reformation and the English Medieval parish chantry. In: D. Gaimster \& R. Gilchrist, eds. The Archaeology of Reformation, 1480-1580. Leeds: Maney Publishing, pp. 342-355.

Rose, E. M., 2015. The Murder of William of Norwich: The Origins of the Blood Libel in Medieval Europe, Oxford: Oxford University Press.

Rose, M., 1996. The Vault Bosses. In: I. Atherton, ed. Norwich Cathedral: church, city, and diocese, 1096-1996. London: Hambledon Continuum, pp. 363-378.

Rose, M. \& Hedgecoe, J., 1997. Stories in Stone: The Medieval Roof Carvings of Norwich Cathedral. London: Herbert Press.

Rosewell, R., 2008. Medieval wall paintings in English \& Welsh churches.

Woodbridge: Boydell.

Ross, E. M., 1997. The Grief of God: Images of the Suffering Jesus in Late Medieval England. Oxford: Oxford University Press.

Russell, F. W., 1859. Kett's rebellion in Norfolk : being a history of the great civil commotion that occurred at the time of the reformation, in the reign of Edward VI.. London: Longmans.

Rye, W., 1872. Norfolk Church Goods, temp. Edward VI. In: Norfolk Archaeology. Norwich: Norfolk and Norwich Archaeological Society, pp. 20-44.

Sawyer, F. E., 1883. S. Wilfirth's Life in Sussex and Introduction of Christianity. In: Sussex Archaeological Collections Relating to the History and Antiquities of the County. Sussex: H.W Wolff, pp. 101-128.

Scribner, R. W., 1993. he Reformation, Popular Magic, and the "Disenchantment of the World". The Journal of Interdisciplinary History, 23(3), pp. 475-494.

Shagan, E. H., 2003. Popular Politics and the English Reformation. Cambridge: Cambridge University Press. 
Sharpe, G. R., 2011. Historic English churches : a guide to their construction, design and features. London: I.B. Tauris.

Shaw, W. A., 1900. A history of the English Church during the civil wars and under the Commonwealth, 1640-1660. London: Longman, Green and Co.

Sill, G. G., 1996. A handbook of symbols in Christian art. New York: Simon \& Schuster.

Smith, D. M., Kemp, B. R. \& Harper-Bill, C. eds., 1980. English Episcopal Acta: Norwich, 1070-1214,. Oxford: Oxford University Press.

Smith, K., 2012. The monk who crucified himself. In: E. Gertsman \& J. Stevenson, eds. Thresholds of Medieval Visual Culture: Liminal Spaces. Woodbridge: Boydell, pp. 4472.

Soden, I., 2003. The conversion of former monastic buildings to secular use : the case of Coventry. In: D. Gaimster \& R. Gilchrist, eds. The Archaeology of Reformation, 1480-1580. Leeds: Maney Publishing, pp. 280-289.

Spicer, A., 2003. Iconoclasm and adaptation : the Reformation of the churches in Scotland and the Netherlands. In: D. Gaimster \& R. Gilchrist, eds. The Archaeology of Reformation, 1480-1580. Leeds: Maney Publishing, pp. 29-43.

Spraggon, J., 2003. Puritan Iconoclasm during the English Civil War: The Attack on Religious Imagery by Parliament and Its Soldiers. Woodbridge: Boydell Press.

Stewart, A., 2003. The Cradle King: A Life of James VI \& I. London: St. Martin's Press. Strange, E. F., 1913. The Rood-Screen of Cawston Church. The Volume of the Walpole Society, 2(1), pp. 81-87.

Strong, R. C., 1977. The cult of Elizabeth : Elizabethan portraiture and pageantry. London: Thames and Hudson.

Strype, J., 1821. The life and acts of Matthew Parker By. Oxford: Claredon Press.

Strype, J., 1824. Historical and Biographical Works. Oxford: Clarendon Press.

Suckling, A., 1846. The History and Antiquities of the County of Suffolk. Ipswich: WS Crowell.

Tanner, J. R., 1922. Tudor constitutional documents, A.D. 1485-1603. Cambridge:

Cambridge University Press.

Tanner, N., 1984. Church in Late Medieval Norwich, 1370-1532. Montecassino:

Pontifical Institute of Mediaeval Studies. 
Tanner, N., 1984. The Church in Late Medieval Norwich: 1370-1532. Toronto(Ont.): Pontifical Institute of Medieval Studies.

Tarlow, S., 2003. Reformation and Transformation: What Happened to Catholic Things in a Protestant World?. In: D. Gaimster \& R. Gilchrist, eds. The archaeology of the Reformation 1480-1580. Leeds: Maney Publishing, pp. 108-121.

Tawney, R. H., 1912. The Agrarian Problem in the Sixteenth Century. New York: Longmans, Green and Company.

Taylor, R., 1821. Index monasticus: or the abbeys and other monasteries, alien priories, with their dependencies, formerly established in the diocese of Norwich and the ancient kingdom of East Anglia, systematically arranged and briefly described and illustrated by maps of Suffolk, Norfolk. London: Richard and Authur Taylor.

Taylor, R., 2005. How to read a church : a guide to symbols and images in churches and cathedrals. Mahwah(NJ): Hidden Spring.

Thirsk, J., 1987. Agriculutral Regions and Agarian History in England, 1500-1750. London: Macmillan.

Thomas, K., 1971. Religion and the Decline of Magic: Studies in Popular Beliefs in Sixteenth and Seventeenth Century England. London: Weidenreich and Nicolson. Thomas, K., 2009. The ends of life : roads to fulfilment in early modern England. Oxford: Oxford University Press.

Thompson, D. V., 1956. The Materials and Techniques of Medieval Painting. Mineola: Dover Publications.

Tittler, R., 1998. The Reformation and the Towns in England: Politics and Political Culture, c. 1540-1640. Oxford: Clarendon.

Tyacke, N., 1973. Puritanism, Arminianism and Counter-Revolution. In: C. Russel, ed. The Origins of the English Civil War. 1973: Barnes \& Noble Books, pp. 119-143.

Tyacke, N., 1998. Introduction: Re-thinking the "English Reformation. In: N. Tyacke, ed. England's Long Reformation 1500-1800. Oxford: Routledge, pp. 1-32.

Tyler, J. E., 1847. Primitive Christian worship: or, The evidence of holy Scripture and the Church, concerning the invocation of saints and angels, and the blessed virgin Mary. 2nd ed. London: Society for Promoting Christian Knowledge.

Tyler, L. G., 1893. The Calthorpes. In: L. G. Tyler, ed. William and Mary College quarterly historical magazine. Williamsburg(VA): William and Mary College, pp. 106112. 
Walsham, A., 1998. The Paochial Roots of Laudianism Revisited: Catholics, AntiCalvinists and 'Parish Anglicans' in Early Stuart England. The Journal of Ecclesiastical History, 49(4), pp. 620-651.

Walsham, A., 2008. The Reformation and 'The Disenchantment of the World' Reassessed,. The Historical Journal, 51(2), pp. 497-528.

Walsham, A., 2010. Wyclif's Well: Lollardy, Landscape and Memory in PostReformation England. In: A. McShane \& G. Walker, eds. The extraordinary and the everyday in early modern England. New York: Palgrave Macmillan, pp. 142-160. Walters, H. B. ed., 1965. Inventory of Norfolk Church Goods 1552: Hundred of Smithdon. In: Norfolk archaeology; or, Miscellaneous tracts relating to the county of Norfolk. Norwich: Norfolk and Norwich Archaeological Society, pp. 216-235.

Wandel, L. P., 1995. Voracious idols and violent hands : iconoclasm in Reformation Zurich, Strasbourg, and Basel. Cambridge: Cambridge University Press.

Warren, W. L., 1973. Henry II. Berkeley: University of California Press.

Waters, C. E. C., 1886. A handbook of Christian symbols and stories of the saints as illustrated in art. Boston: Ticknor \& Co.

Weever, J., 1767. Antient funeral monuments, of Great-Britain, Ireland, and the islands adjacent by, 1576-1632. London: W. Tooke.

White, F., 1854. History, Gazetteer, and Directory of Norfolk. Broomhall Terrace:

Francis White \& Co.

Whiting, R., 2010. The Reformation of the English Parish Church. Cambridge: Cambridge University Press.

Wildridge, T. T., 1899. The Grotesque in Church Art. London: Williams Andrews \& Co.

Williamson, W. W., 1955-57. Saints on Norfolk roodscreens and pulpits. In: Norfolk Archaeology. Norwich: Norfolk \& Norwich Archaeological Society, pp. 299-346. Wills, G., 1962. Collecting Copper and Brass. New York: Bell Publishing Co. Workman, H. B., 1916. The Foundation Of Modern Religion: A Study In The Task And Contribution Of The Mediaeval Church (1916). London: Fleming H. Revell Companty. Yates, E. T., 1884. A Transcript of the Register of the Parish of Burgh, 1563-1810 . In: Norfolk archaeology; or, Miscellaneous tracts relating to the county of Norfolk. Norwich: Norfolk and Norwich Archaeological Society, pp. 37-58. 
Yates, N., 2012. Anglicans, Old Catholics and Reformed Catholics in late nineteenthcentury Europe . In: S. J. Brown \& P. B. Nockles, eds. The Oxford movement : Europe and the wider world 1830-1930. Cambridge: Cambridge University Press, pp. 249-265. 